JAN SCHNITZER

THE NUREMBERG JUSTICE TRIAL 1947

VENGEANCE OF THE VICTORS?

\title{
LLM THESIS
}

LAWS 591

FACULTY OF LAW

TE WHARE WĀNANGa O TE ŪPOKO O TE IKA A MĀUI

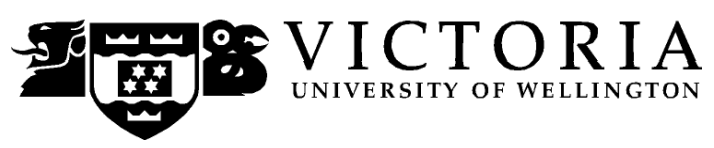

2010 
In memory of the victims of the German

judiciary between 1933 and 1945 
ABSTRACT ......................................................................................................9

ACKNOWLEDGEMENTS.............................................................................. 11

I INTRODUCTION........................................................................ 13

II LEGAL BASIS OF THE TRIAL ......................................................... 19

A The Allies as the Controllers of the Legislative Power in Germany after World War II ............................................................ 19

1 The legitimisation of the trial by Allied documents ................... 19

(a) Declaration on German Atrocities (Moscow Declaration

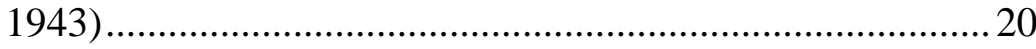

(b) London Agreement of 8 August 1945 …............................ 22

(c) Charter of the International Military Tribunal .................... 25

(d) Allied Control Council Law No. 10 .....................................2 29

(e) Ordinance No. 7 of the US Military Government for

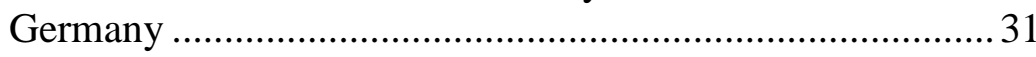

(f) Judgment of the International Military Tribunal.................. 33

2 Compatibility with existing international law and customs........ 34

(a) Non-applicability of Hague Convention No. IV (Laws and Customs of War on Land) .................................. 34

(b) The issue of Germany's remaining sovereignty.................. 37

(i) View of US Military Tribunal III................................... 38

(ii) Dissenting view of Judge Blair ....................................... 41

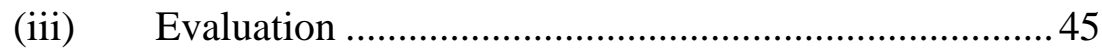

(c) The implementation of a purely US court........................... 47

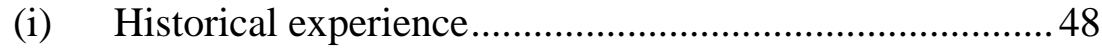

(ii) The violation of the principle of separation of powers ....51

B The Moral Necessity of the Trial ...........................................55

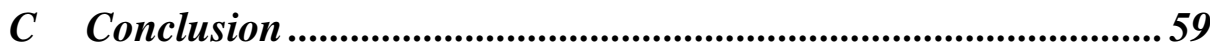


III INVOLVED PARTIES 61

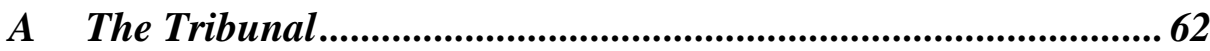

$1 \quad$ The judges and their qualifications ............................................63

2 Independence of the judges from US post-war politics ............. 65

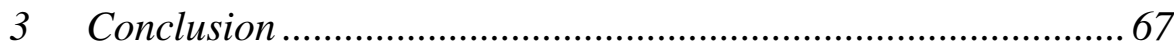

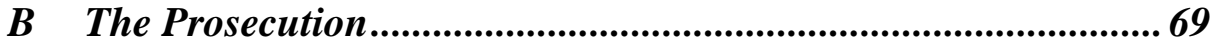

$1 \quad$ The prosecutors and their qualifications ................................. 70

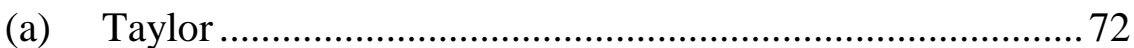

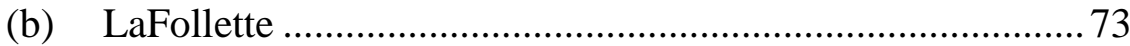

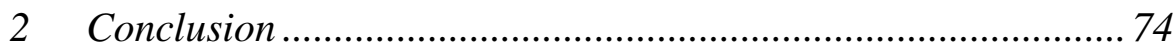

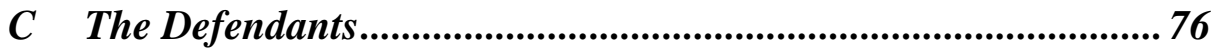

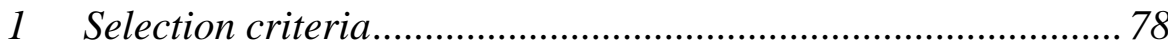

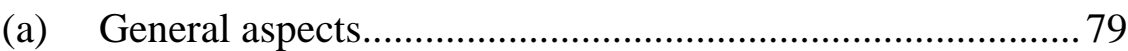

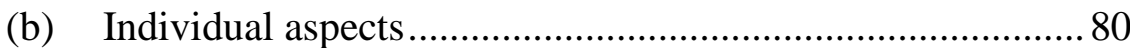

(i) Officials of the Reich Ministry of Justice ....................... 81

(ii) Members of the National Socialist People's Court.......... 82

(iii) Members of National Socialist Special Courts ............ 84

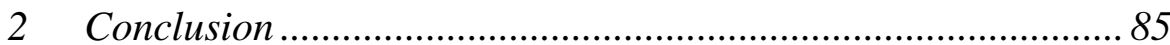

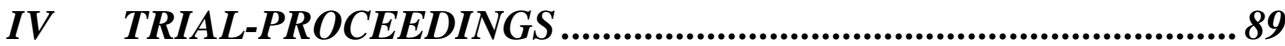

A The Creation of a New International Criminal Law .................. 90

$1 \quad$ The charges and their development ........................................ 91

(a) Conspiracy to commit war crimes and crimes against

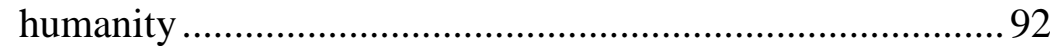

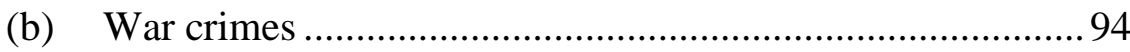

(c) Crimes against humanity................................................... 96

(d) Membership in criminal organisations............................. 100

2 The ex post facto principle (nullum crimen sine lege, nulla poena sine lege)....

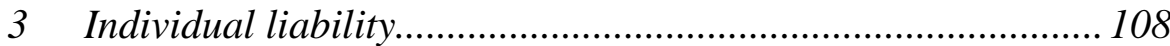

$4 \quad$ The tu quoque argument ......................................................... 111 


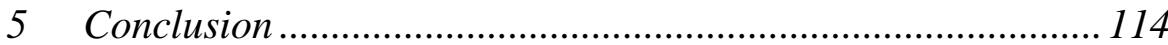

B Fairness of the Trial ................................................................. 115

V JUDGMENT OF THE TRIBUNAL ........................................... 121

A General Remarks ...................................................................... 121

1 The Tribunal's analysis of the German law under the Nazis .. 122

(a) Ermaechtigungsgesetz (Enabling Act 1933).................... 123

(b) Arbitrariness in criminal law ........................................... 124

(c) Discrimination against minorities ................................. 127

(d) Expansion of the German law on occupied territories ....... 128

(e) Courts and the law of procedure ...................................... 129

(f) The execution of the law in Nazi Germany ..................... 131

(i) Hitler as supreme judge............................................. 131

(ii) Execution of Hitler's will............................................ 133

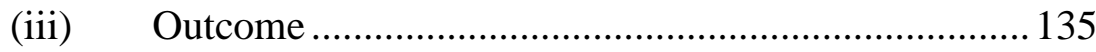

2 The Tribunal's evaluation of the legality of Nazi laws............ 137

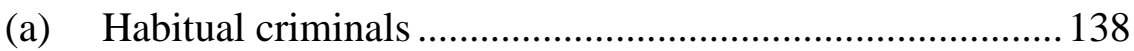

(b) Plunder in German territory .......................................... 138

(c) Crimes against the wartime economy .............................. 139

(d) Undermining military efficiency ..................................... 139

(e) Treason and High Treason ............................................. 141

(f) The Nacht und Nebel Erlass (Night and Fog Decree)........ 142

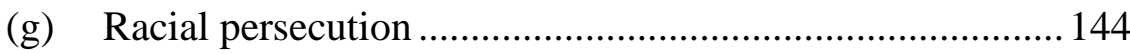

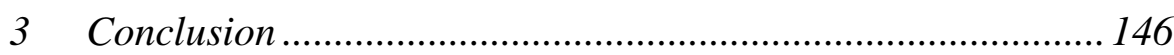

B Individual Verdicts and Sentences.......................................... 147

1 The Tribunal's evaluation of the defendant's role ........................ in Nazi Germany .................................................................. 149

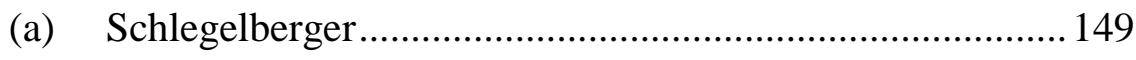

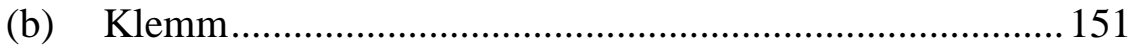

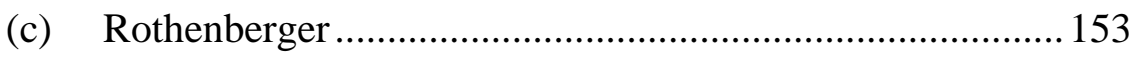

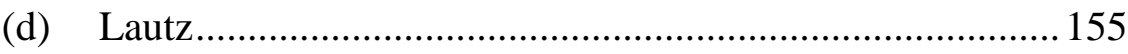


(e) Mettgenberg ….......................................................... 156

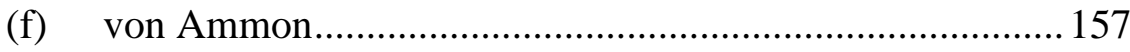

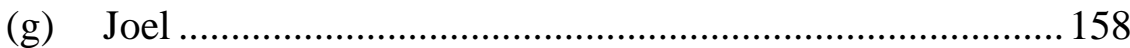

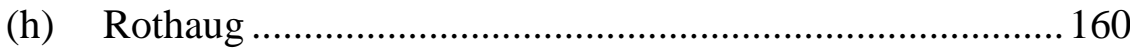

(i) Barnickel, Petersen, Nebelung and Cuhorst...................... 163

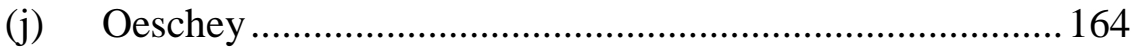

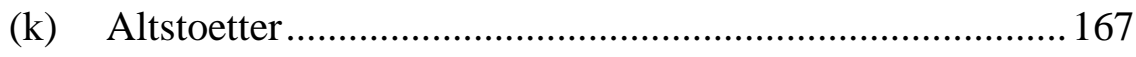

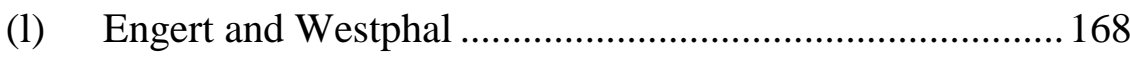

2 The Tribunal's relatively mild sentencing ............................. 169

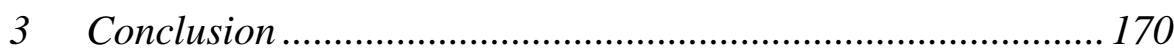

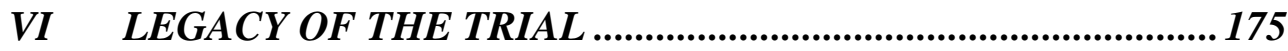

A The Establishment of a New International Criminal Law ....... 175

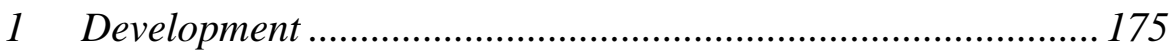

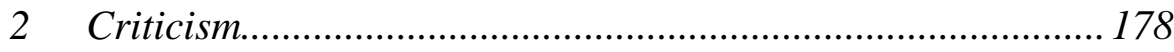

3 Conclusion ......................................................................... 180

B The Failure of the US War Crimes Trial Programme............... 182

1 The upcoming Cold War .......................................................... 183

2 The resistance of Germany's post-war judiciary.................... 186

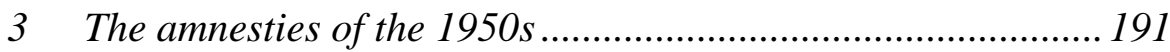

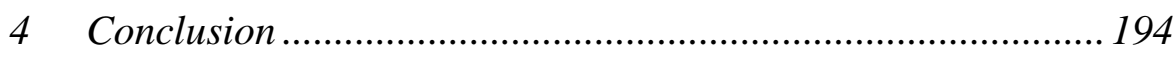

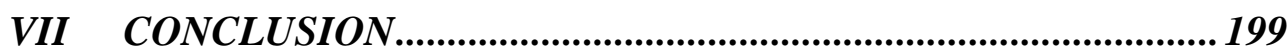

APPENDIX: PICTURES FROM THE TRIAL .....................................207

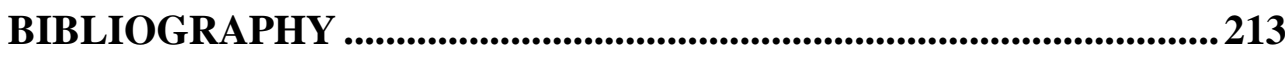




\section{ABSTRACT}

Nuremberg became famous for the 13 Nuremberg Trials against the leading German officials after World War II. Following the first trial against the remaining Nazi leaders before the Allied International Military Tribunal in 1945-1946, the United States initiated 12 subsequent proceedings against leading members of all areas of Germany's society. The Justice Trial against 16 representatives of Nazi Germany's judicial system was the third of these trials and held before US Military Tribunal III in 1947.

Organised and held under the aegis of the United States as one of the war's victors, the trials were seen by many as simple acts of vengeance, hidden behind a smokescreen of legality. Therefore, especially in post-war Germany, the trials were often described as victor's justice. Yet, besides investigations relating to specific aspects of this allegation, a profound analysis of this issue has not been done for the Justice Trial.

This study aims to help in closing this gap. Focussing on the issue of victor's justice, the work analyses and evaluates all stages of the Justice Trial, from its legal basis, to the planning and preparation, to the proceedings and judgments, to the enforcement of the sentences after the trial. In the end, it is concluded that only two aspects, the violation of the principle of separation of powers and the restriction to initiate trials only against German nationals, can be seen as examples of victor's justice.

All other aspects cannot be proved as examples of victor's justice; whether Germany's state sovereignty was violated, whether the judges were impartial, whether the ex post facto principle was violated, whether the defendants could be held individually responsible, whether the defendants received a fair trial, whether the trial was justified from a moral point of view, whether the defendants were selected for appropriate reasons, whether the Tribunal analysed and evaluated the Nazi legal system and the defendant's role therein reasonably, whether the US judges and prosecutors were qualified enough, and whether the early release of the convicted defendants in the 1950s was arbitrary.

The Justice Trial and all other Nuremberg Trials, in many ways, set unique precedents for international criminal law. The legacy, therefore, is primarily a positive one. Thus, overall, it is concluded that the limited examples of victor's justice within the Justice Trial do not ultimately undermine these achievements.

The text of this paper (excluding abstract, table of contents, footnotes, bibliography and appendices) comprises approximately 49,608 words. 


\section{ACKNOWLEDGEMENTS}

I wish to first acknowledge and thank my supervisor, Dr Grant Morris, for his advice, guidance and patience throughout the working process. I also want to thank Jonathan Dempsey, who always helped when needed.

Further, I thank my dear friends Marc, Norbert, Katrin and Dominik, who especially helped me during the first half of my study when difficult times in private life almost prompted me to end this project.

I thank my family for their long-distance encouragement and support, and particularly my Mum, who made one of the longest possible journeys on earth to stand beside me when I needed someone close.

In the second half of my study, I primarily worked in room 227 of the Law library, and I want to thank my fellow students and roommates Joy, Symone, Rani and Jule for their company during this time.

Last but not least, I thank my flatmates Tina and Ange for creating an atmosphere in which I felt at home and for always listening when I needed to talk. 


\section{INTRODUCTION}

The name Nuremberg became well known for the trial against the German major war criminals after World War II. On 1 October 1946, the International Military Tribunal sentenced prominent Nazis like Hermann Goering, Rudolf Hess and Albert Speer, among others, to death or long time imprisonment. ${ }^{1}$ The judgment itself was a document of historic significance, which for the first time brought to light the enormous number of violent crimes committed by Nazi Germany. Furthermore, this trial was one of the first and most important steps on the way to an accepted international criminal law, which did not really exist prior the event.

Reporters, politicians, writers and the world public stood still when it came to the reading of the judgment by the Tribunal; afterwards, people attempted to get back to a normal life, especially in Europe where the war had left millions without a home and with terrible trauma. However, the four major allied winners of the war, the United States of America, Great Britain, the Soviet Union and France, had decided that there needed to be more trials to investigate the atrocities carried out by Nazi Germany before and during World War II. ${ }^{2}$

Originally, it was planned that the International Military Tribunal would continue its work and proceed with a series of trials following the trial of the major war criminals but, for different political and strategic reasons relating to the upcoming Cold War, it remained the only trial held by the International Military Tribunal. ${ }^{3}$ Though, by Allied Control Council Law No. 10, enacted on 20 December 1945, each of the four Allies received

\footnotetext{
${ }^{1}$ The United States of America, the French Republic, the United Kingdom of Great Britain and Northern Ireland, and the Union of Soviet Socialist Republics v Hermann Wilhelm Goering and others (International Military Tribunal) (1945-1946) I Trial of the Major War Criminals before the International Military Tribunal 365-367.

2 Jonathan Friedman "Law and Politics in the Subsequent Nuremberg Trials, 1946-1949" in Patricia Heberer and Juergen Matthaeus (eds) Atrocities on Trial: Historical Perspectives on the Politics of Prosecuting War Crimes (University of Nebraska Press, Lincoln, 2008) 75-77.

${ }^{3}$ Ibid, 76-77.
} 
the power to establish their own courts for trying Nazi criminals within their occupation zone. ${ }^{4}$ The city of Nuremberg, as the location where the major trial was held, was part of the American zone of occupation; therefore, the United States Military Government for Germany was in charge for the so called subsequent Nuremberg proceedings. ${ }^{5}$

Since the International Military Tribunal had already established the criminality of war crimes, aggressive war and crimes against humanity, these trials were for the purpose of determining the guilt of second-tier Nazis accused of those crimes. ${ }^{6}$ As many as 185 defendants, representing different sectors of German society, were indicted before American military tribunals in a series of 12 trials. $^{7}$ The defendants were grouped according to their main area of activity, namely medical, legal, ethnological, economic and political. ${ }^{8}$

From 17 February 1947 until 18 October 1947, the third of these subsequent trials was held under US Military Tribunal III, charging the representatives of the legal group with several crimes. ${ }^{9}$ It was the case of The United States of America v Josef Altstoetter and others, generally known as the Justice or Judges' Trial.

In his opening statement for the prosecution, Chief Prosecutor Brigadier General Telford Taylor stated: ${ }^{10}$

\footnotetext{
This case is unusual in that the defendants are charged with crimes committed in the name of the law. These men, together with their deceased or fugitive colleagues, were the embodiment of what passed for justice in the Third Reich. Most of the defendants have served, at various times, as judges, as state prosecutors, and as officials of the Reich Ministry of Justice. All but one are professional jurists; they are well
}

\footnotetext{
${ }^{4}$ M Cherif Bassiouni Crimes against Humanity in International Criminal Law (2 ed, Kluwer Law International, The Hague, 1999) 531-532.

${ }^{5}$ Ibid, 533.

6 "Subsequent Nuremberg Proceedings" www.ushmm.org (last accessed 16 March 2010).

${ }^{7}$ Friedman, above n 2, 75 .

8 "Nurnberg Military Tribunals: Indictments" www.loc.gov/rr/frd (last accessed 16 March 2010).

${ }^{9}$ The United States of America v Josef Altstoetter and others (Justice Case) (1947) III Trials of War Criminals before the Nuernberg Military Tribunals under Control Council Law No. 10 (Case No 3) 3-6.

${ }^{10}$ Ibid, 31.
} 
accustomed to courts and courtrooms, though their present role may be new to them.

The Justice Trial was a difficult one for the American occupants as well as for the German public. Most of the accused men were not obviously evil like some of the defendants in the major trial before. During the Nazi reign, all 16 defendants were officials in the Reich Ministry of Justice or members of the People's Court and Special Courts in Germany. ${ }^{11}$ They had served for the German Government following and applying the given legislation in Nazi Germany. Therefore, this trial, like all other Nuremberg Trials, was often under fire for being victor's justice.

The German jurisprudence could not accept that the Nazi crimes had been punished on the basis of international law; especially the violation of the rules of the ex post facto principle was criticised. ${ }^{12}$ Hence, generations of German post-war jurists were taught that Nuremberg was victor's justice and, even today, some jurists treat the Nuremberg Trials as questionable. ${ }^{13}$ Accordingly, my thesis will analyse the question to what extent victor's justice was really committed within the Justice Trial.

Among the winners of World War II, the United States made clear from the beginning that there had to be some punishment of the Nazi officials. ${ }^{14}$ Yet, instead of using martial law and just shoot or imprison the responsible Germans, the US Government favoured regular court trials. ${ }^{15}$ However, many people were and are still convinced that these trials were purely a creation of the victors to exercise vengeance on the Germans.

The term victor's justice is strongly connected with the concept of vengeance. It was especially popular in post-war Germany and "implies the imposition of an alien, largely inappropriate, and unfair legal procedure

\footnotetext{
${ }^{11}$ Ibid, 3.

12 Klaus Baestlein "Der Nuernberger Juristenprozess und seine Rezeption in Deutschland" in Lore Maria Peschel-Gutzeit (ed) Das Nuernberger Juristen-Urteil von 1947 (Nomos Verlag, Baden-Baden, 1996) 9.

${ }^{13}$ Ibid.

${ }^{14}$ Robert K Woetzel The Nuremberg Trials in International Law with a Postlude on the Eichmann Case (rev ed, Stevens, London, 1962) 3-5.

${ }^{15}$ Telford Taylor "The Nuremberg Trials" (1955) 55 Colum L Rev 488, 499.
} 
against the vanquished." ${ }^{16}$ Regarding this issue, a lot of literature is available relating to the trial of the major war criminals, but not much work has been done for the subsequent trials and, among these, particularly not for the Justice Trial. Thus, this thesis will investigate different aspects of what could be seen as victor's justice within the Justice Trial and will evaluate them. The paper is structured chronologically, based on the historical facts. Within each chapter, the facts of the trial will be detailed and questioned using different aspects of victor's justice.

The question of victor's justice is broad and vague. Therefore, it is necessary to divide it into several sub-questions, which will be asked and answered in their respective chapters. The outcome will be an overall conclusion that argues either to what extent the Justice Trial was only the framework for exercising vengeance on the defeated Germans or that victor's justice was not committed in this trial.

Chapter II analyses the legal background of the trial by examining the following issues:

Who had the legal and political power in Germany at the time of the trial? Were the Allies entitled to legislate for the German territory?

Was the trial legitimated by existing international law?

Why did a German court not deal with this case?

Why did the Tribunal consist only of judges from the United States?

Was there a moral necessity for such a trial?

In chapter III, the involved parties of the trial will be introduced and the issues of victor's justice will be analysed by discussing the following questions:

\footnotetext{
16 Patricia Heberer and Juergen Matthaeus "Introduction: War Crimes Trials and the Historian" in Patricia Heberer and Juergen Matthaeus (eds) Atrocities on Trial: Historical Perspectives on the Politics of Prosecuting War Crimes (University of Nebraska Press, Lincoln, 2008) xv.
} 
Were the US judges sufficiently qualified to judge over jurists from another legal system?

Were the deciding judges of the Tribunal independent from US postwar politics?

Was the prosecution counsel sufficiently qualified to accuse jurists from another legal system?

What were the criteria for selecting the defendants?

Chapter IV looks at the trial proceedings and focuses on the following questions:

Were the charges, especially the count of crimes against humanity, compatible with existing rules of criminal law? What about the ex post facto principle? Could the defendants be held individually responsible?

Was the tu qouque argument a valid argument used by the defence?

Did the defendants receive a fair hearing?

Chapter V analyses the judgment of US Military Tribunal III and discusses the following questions:

Did the Tribunal analyse and evaluate the German legal system under the Nazis appropriately?

Did the Tribunal evaluate the role of the defendants in Nazi Germany appropriately?

Why were the individual verdicts relatively mild compared to sentences given in other trials at Nuremberg?

Finally, in chapter VI, the legacy of the Justice Trial and of the Nuremberg Trials in general will be discussed by examining the following questions: 
Why did the US Military Government initiate only this one trial against members of the Nazi judiciary and many other German jurists were not tried at all?

Why were all convicted defendants released long before the end of their prison terms?

A conclusion will be drawn in chapter VII stating that before, during and after the trial there were certain issues that have to be seen as victor's justice. However, by looking at the whole situation after World War II, it is exceptional how the Allies, and in particular the United States, dealt with the defeated Germans. The atrocities committed by Nazi Germany, not only in conquered territories during the war but also within Germany itself, were unique in world history and needed a significant response. The Nuremberg Trials gave such a response and were, in respect to the given circumstances, an exceptional and admirable way to deal with those responsible for it.

Nuremberg set a precedent for international law, and the Justice Trial clarified once and for all that no jurist should ever again just apply the given law of one's country without paying respect to the most basic moral principles of humankind. The few aspects within the Justice Trial that have to be evaluated as examples of victor's justice do not ultimately undermine these achievements. Therefore, although it was the victorious Allies who presided over the vanquished Germans, the Nuremberg Trials in my opinion cannot be seen as vengeance of the victors. 


\section{LEGAL BASIS OF THE TRIAL}

This chapter analyses the question whether victor's justice can be seen in the establishment of US Military Tribunal III, and will conclude that this is not the case as the Allies legally exercised governmental power in Germany after World War II.

After the war, the victorious Allies divided the German territory in four occupation zones. The Military Government of each Allied Power became authorised to rule and legislate for their part of the German territory. It will be shown that the enacting of new laws by the Allied authorities to create a legal basis for the trials of Nazi war criminals did not violate international law, although the reasons differ among experts.

Furthermore, this chapter will deal with the question of whether the Justice Trial was necessary in a moral way, an argument those responsible in the US administration always stressed as a major reason for the Nuremberg Trials. It will be concluded that there truly was a moral necessity for the conduct of the trial. After the outrageous atrocities committed by the Nazis within their own country, hidden behind a smokescreen of alleged legality, there was no better way to deal with it.

\section{A The Allies as the Controllers of the Legislative Power in Germany after World War II}

1 The legitimisation of the trial by Allied documents 
(a) Declaration on German Atrocities (Moscow Declaration 1943)

The Moscow Declaration from 30 October 1943 is the real starting point of the legitimisation process for the International Military Tribunal and also for the subsequent US military tribunals.

Previously, several official actions were taken by statesmen and governments: President Roosevelt of the United States and Prime Minister Churchill from Great Britain simultaneously warned the Axis Powers, namely Germany, Italy and Japan, on 25 October 1941 that retribution would follow in the wake of their crimes. ${ }^{17}$ On 21 August 1942, President Roosevelt warned again and issued a statement "that the time will come when they shall have to stand in courts of law in the very countries which they are now oppressing and to answer for their acts."18

Prime Minister Churchill declared on 8 September 1942 "that those guilty of war crimes will 'have to stand up before tribunals in every land where the atrocities have been committed." 19 The Governments in exile of nine German-occupied countries issued the St. James Declaration on 13 January 1942 in London, wherein they explicitly rejected punishment by acts of vengeance and promulgated "that the signatory powers 'place among their principal war aims the punishment, through the channel of organized justice, of those guilty of or responsible for these crimes" ${ }^{\prime, 20}$. Furthermore, on 7 October 1942, the decision of seventeen nations to form the United Nations Commission for the Investigation of War Crimes was announced in Washington and London. ${ }^{21}$

\footnotetext{
${ }^{17}$ Woetzel, above n 14,3 .

${ }^{18}$ Whitney R Harris Tyranny on Trial: The Evidence at Nuremberg (Southern Methodist University Press, Dallas, 1954) 4.

${ }^{19}$ Woetzel, above n 14, 4.

20 Yves Beigbeder Judging War Criminals: The Politics of International Justice (St. Martin's Press, New York, 1999) 32.

${ }^{21}$ Woetzel, above n 14, 4. The Commission was finally established in October 1943, but it was not more than a weak evidence-collecting body that left investigations to its member states. By the time Nuremberg was in the works, it was unceremoniously dismantled. Gary
} 
However, until the Moscow Conference there was no joint declaration of the major Allied Powers, who at the time were the United States, Great Britain and the Soviet Union only. At the conference, the representatives of these countries, President Roosevelt, Prime Minister Churchill and Soviet-leader Stalin, debated for the first time together about what should happen to the German officials after the war. In the end, they declared the following: $:^{22}$

The United Kingdom, the United States and the Soviet Union have received from many quarters evidence of atrocities, massacres and coldblooded mass executions which are being perpetrated by the Hitlerite forces in the many countries they have overrun and from which they are now being steadily expelled. The brutalities of Hitlerite domination are no new thing and all the peoples or territories in their grip have suffered from the worst form of government by terror....

At the time of the granting of any armistice to any government which may be set up in Germany, those German officers and men and members of the Nazi party who have been responsible for, or have taken a consenting part in the above atrocities, massacres, and executions, will be sent back to the countries in which their abominable deeds were done in order that they may be judged and punished according to the laws of these liberated countries and of the free governments which will be created therein. ...

The above declaration is without prejudice to the case of the major criminals, whose offences have no particular geographical localisation and who will be punished by the joint decision of the Government of the Allies.

Although the outcome of this statement finally resulted in the Nuremberg Trials, to the three Allies it was not at all obvious at the time that trials were the best way to deal with the defeated Germans. ${ }^{23}$ When Churchill and Roosevelt met in Quebec in September 1944, they principally adopted the Morgenthau Plan, under which approach, as part of the denazification process of Germany, the major Nazi war criminals were to be shot on sight and lesser Nazis were sent to repair Allied lands damaged by

J Bass Stay the Hand of Vengeance: The Politics of War Crimes Tribunals (Princeton University Press, Prinveton, 2002) 149.

${ }_{22}$ Moscow Declaration on German Atrocities (released 1 November 1943).

${ }^{23}$ Bass, above n 21, 147. 
the war. ${ }^{24}$ Henry Morgenthau Jr. was America's Secretary of the Treasury and said what the British and American public would have preferred to hear at the time. ${ }^{25}$

However, in the end, legalism triumphed because President Roosevelt became convinced by the plan of his Secretary of War, Henry L Stimson, that war criminals had to be put on trial for the reason of America's own domestic respect of due process, and Roosevelt was able to convince Churchill, who had called for the execution of the top Axis leaders without trial, of this idea. ${ }^{26}$

Stalin, on the other side, was in favour of summary executions at any time. At the Tehran Conference, which was held in 1943 but after the Moscow Conference, he proposed the shooting of 50,000 to 100,000 Germans. ${ }^{27}$ When he had to realise that this was unlikely, he tried to arrange show trials, which would have not been too different from those established in Stalin's purges. ${ }^{28}$ In the end, fortunately, he did not succeed with this idea

(b) London Agreement of 8 August 1945

At the conference in Yalta, the three Allies declared on 11 February 1945 that they would accept the unconditional surrender of the Axis Powers only. ${ }^{29}$ Furthermore, they agreed that the Allied Powers will each occupy a separate zone of Germany with coordinated administration and control through a Central Control Council composed of the supreme commanders of the Allied armed forces at Berlin. ${ }^{30}$ France was to be invited to take over a zone of occupation and to participate as a fourth member of the Control

\footnotetext{
${ }^{24}$ Beigbeder, above $\mathrm{n} 20,31$. The author refers to the Quebec Conference held in September 1942, but this is obviously a typo as no conference was held in Quebec at the time.

${ }^{25}$ Bass, above n 21, 147.

${ }^{26}$ Ibid, $147-148$.

${ }^{27}$ Ibid, 147.

${ }^{28}$ Ibid.

${ }^{29}$ Justice Case, above n 9, 1187.

${ }^{30}$ Ibid.
} 
Council for Germany. ${ }^{31}$ Also, it was announced the "inflexible purpose to ... bring all war criminals to just and swift punishment" ${ }^{32}$.

On 8 May 1945, the German armed forces surrendered unconditionally, and on 5 June 1945, by the Berlin Declaration, the Allied Powers, including France, which had accepted the invitation from Yalta, took over the state authority in Germany. ${ }^{33}$ Additionally, the Allies declared that the punishment of European Axis war criminals "was made a primary task of the military occupation of Germany.. ${ }^{34}$ However, the question about the exact procedure for dealing with the war criminals remained open.

Consequently, on 26 June 1945, representatives of the four major Allied Powers met in London and opened formal discussions toward a quadripartite agreement for an international trial. They lasted for six weeks paying tribute to very different ideas among the delegates. ${ }^{35}$ The participants from the Soviet Union, for example, were convinced that the Nazi leaders were already guilty. General Nikitchenko, who later became one of the judges of the International Military Tribunal in the trial against the major war criminals, stated: ${ }^{36}$

The fact that the Nazi leaders are criminals has already been established.

The task of the Tribunal is only to determine the measure of guilt of each particular person and mete out the necessary punishment - the sentences.

This was absolutely contrary to the ideas of the US delegation. US Supreme Court Justice Robert H Jackson, who later became the Chief Prosecutor for the United States before the International Military Tribunal, made clear that "the Moscow and Yalta declarations 'are an accusation and not a conviction.' ... The United States had decided against 'political

\footnotetext{
${ }^{31}$ Ibid.

${ }^{32}$ Woetzel, above n 14,5 .

${ }^{33}$ Berlin Declaration Regarding the Defeat of Germany and the Assumption of Supreme Authority by Allied Powers (5 June 1945), preamble.

${ }^{34}$ Justice Case, above n 9, 1187.

${ }^{35}$ Taylor "The Nuremberg Trials", above n 15, 498.

${ }^{36}$ Ibid, 499.
} 
executions,' and 'if we are going to have a trial, then it must be an actual trial.",

However, after long discussions the representatives of the four Allied Powers resolved their remaining differences and, on 8 August 1945, promulgated the London Agreement "for the Prosecution and Punishment of the Major War Criminals of the European Axis"38, embodying Jackson's conception rather than Nikitchenko's. ${ }^{39}$ Later on, 19 other countries adhered to the Agreement, reinforcing its international credentials. ${ }^{40}$

With the London Agreement, the four Allies took over the responsibility to prosecute and punish the major war criminals and set the stage not only for the trial before the Nuremberg International Military Tribunal but also for the subsequent Nuremberg Trials. With respect to the Justice Trial, the relevant parts of the Agreement read as follows: ${ }^{41}$

Now therefore the Government of the United States of America, the Provisional Government of the French Republic, the Government of the United Kingdom of Great Britain and Northern Ireland and the Government of the Union of Soviet Socialist Republics ... acting in the interests of all the United Nations and by their representatives duly authorized thereto have concluded this Agreement.

Article 1. There shall be established after consultation with the Control Council for Germany an International Military Tribunal for the trial of war criminals whose offenses have no particular geographical location whether they be accused individually or in their capacity as members of organizations or groups or in both capacities.

Article 2. The constitution, jurisdiction and functions of the International Military Tribunal shall be those set out in the Charter annexed to this Agreement, which Charter shall form an integral part of this Agreement.

\footnotetext{
${ }^{37}$ Ibid.

${ }^{38}$ London Agreement (8 August 1945), preamble.

${ }^{39}$ Taylor "The Nuremberg Trials", above n 15, 499-501.

${ }^{40}$ Beigbeder, above n 20, 32 .

${ }^{41}$ London Agreement, above n 38, preamble, arts 1, 2, 4, 6.
} 
Article 4. Nothing in this Agreement shall prejudice the provisions established by the Moscow Declaration concerning the return of war criminals to the countries where they committed their crimes. ...

Article 6. Nothing in this Agreement shall prejudice the jurisdiction or the powers of any national or occupation court established or to be established in any allied territory or in Germany for the trial of war criminals. ...

(c) Charter of the International Military Tribunal

According to Article 2 of the London Agreement, the conference participants issued a charter for an International Military Tribunal, which they attached to and made an integral part of the Agreement. Article 1 of this Charter reads as follows: ${ }^{42}$

In pursuance of the Agreement signed on the $8^{\text {th }}$ day of August 1945 by the Government of the French Republic, the Government of the United Kingdom of Great Britain and Northern Ireland and the Government of the Union of Soviet Socialist Republics, there shall be established an International Military Tribunal ... for the just and prompt trial and punishment of the major war criminals of the European Axis. ...

Hereinafter, the Charter described the power and jurisdiction of the then established International Military Tribunal and defined or recognized the crimes for which the European Axis war criminals were to be tried. ${ }^{43}$ In Article 6 , the crimes which were punishable were listed and defined: ${ }^{44}$

The following acts, or any of them, are crimes coming within the jurisdiction of the Tribunal for which there shall be individual responsibility:

(a) Crimes against peace: namely, planning, preparation, initiation or waging of a war of aggression, or a war in violation of international

\footnotetext{
${ }^{42}$ Charter of the International Military Tribunal (8 August 1945), art 1.

43 Justice Case, above n 9, 1187.

${ }^{44}$ Charter of the International Military Tribunal, above n 42, art 6.
} 
treaties, agreements or assurances, or participation in a common plan or conspiracy for the accomplishment of any of the foregoing;

(b) War crimes: namely, violations of the laws or customs of war. Such violations shall include, but not be limited to, murder, ill-treatment or deportation to slave labor or for any other purpose of civilian population of or in occupied territory, murder or ill-treatment of prisoners of war or persons on the seas, killing of hostages, plunder of public or private property, wanton destruction of cities, towns or villages, or devastation not justified by military necessity;

(c) Crimes against humanity: namely, murder, extermination, enslavement, deportation, and other inhuman acts committed against any civilian population, before or during the war, or persecutions on political, racial or religious grounds in execution of or in connection with any crime within the jurisdiction of the Tribunal, whether or not in violation of the domestic law of the country where perpetrated.

Furthermore, the Charter explained the responsibility of individuals in relation to these crimes: ${ }^{45}$

Article 6. ... Leaders, organizers, instigators and accomplices participating in the formulation or execution of a common plan or conspiracy to commit any of the foregoing crimes are responsible for all acts performed by any persons in execution of such plan.

Article 7. The official position of defendants, whether as Heads of State or responsible officials in Government Departments, shall not be considered as freeing them from responsibility or mitigating punishment.

Article 8. The fact that the Defendant acted pursuant to order of his Government or of a superior shall not free him from responsibility, but may be considered in mitigation of punishment if the Tribunal determines that justice so requires.

Also, the Charter granted a special jurisdiction to declare Nazi groups or organisations as a whole criminal. In the Charter this is stated as follows: ${ }^{46}$

Article 9. At the trial of any individual member of any group or organization the Tribunal may declare (in connection with any act of

\footnotetext{
${ }^{45}$ Ibid, arts 6-8.

${ }^{46}$ Ibid, arts 9-11.
} 
which the individual may be convicted) that the group or organization of which the individual was a member was a criminal organization. ...

Article 10. In cases where a group or organization is declared criminal by the Tribunal, the competent national authority of any Signatory shall have the right to bring individuals to trial for membership therein before national, military or occupation courts. In any such case the criminal nature of the group or organization is considered proved and shall not be questioned.

Article 11. Any person convicted by the Tribunal may be charged before a national, military or occupation court, referred to in Article 10 of this Charter, with a crime other than of membership in a criminal group or organization and such court may, after convicting him, impose upon him punishment independent of and additional to the punishment imposed by the Tribunal for participation in the criminal activities of such group or organization.

In its judgment from 1946, the International Military Tribunal declared that in its opinion the Charter was the expression of international law which existed already at the time of the Charter's creation, and the Charter itself was a contribution to international law. ${ }^{47}$ Consequently, the International Tribunal concluded that the law of the Charter was decisive and binding upon them. ${ }^{48}$

Former Lord Chancellor of Great Britain, Viscount Maugham, criticised this view of the International Military Tribunal. He mentioned that the Charter as drawn did not found its provisions on the rules of international law, and the Allies formulated the Charter on their own authority and created provisions which they thought would be just and proper in the trial of the major war criminals rather than exercising existing international law. ${ }^{49}$ For example, he stated that since the law of nations came into existence there had never been a case $\mathrm{s}^{50}$

${ }^{47}$ Office of United States Chief of Counsel for Prosecution of Axis Criminality Nazi Conspiracy and Aggression: Opinion and Judgment (US Government Printing Office, Washington DC, 1947) 48.

${ }^{48}$ Ibid.

${ }^{49}$ Viscount Frederic H Maugham U.N.O. and War Crimes (John Murray, London, 1951) 18.

${ }^{50}$ Ibid. 
where any individual has been tried for the alleged crime of participating in the waging of an aggressive war or a war in violation of an international treaty, and that no Nation had ever before asserted that such an act was a crime under international law.

Hence, for him, the London Agreement and its annexed Charter as well as the jurisdiction of the International Military Tribunal depended only "on the fact of the unconditional surrender by the German armies and the occupation thereafter of the whole of Germany by the four Powers who signed the document."

Maugham's view was that the International Military Tribunal was without doubt an ad hoc tribunal with a limited jurisdiction, and the London Agreement with the annexed Charter was rather a document of victor's justice to set out rules for the punishment of the defeated Germans than the expression of existing international law. ${ }^{52}$ However, he agreed that the International Military Tribunal, as being the creation of the Charter, was necessarily bound by its terms and the Charter, therefore, was the legal basis of the International Military Tribunal. ${ }^{53}$

Regarding the Justice Trial, the London Agreement together with the annexed Charter established not only the legal basis for the International Military Tribunal but also for the subsequent Nuremberg Trials. When looking at the judgment in the Justice Trial, it becomes clear that the rules and principles set out in the Charter formed the background for the decisions of US Military Tribunal III. Therefore, the Charter was also part of the legitimisation process for Tribunal III.

However, according to Maugham, the code necessarily was derived from the four different systems of Allied national law and, therefore, applied only in the major trial. ${ }^{54}$ Hence, the problem remained that the Charter was created for the joint court of the Allies only and, originally, was not made for the separate courts of each Allied Power within their jurisdictional territories.

\footnotetext{
${ }^{51}$ Ibid, 17.

52 Ibid.

53 Ibid.

${ }^{54}$ Ibid, 49.
} 
(d) Allied Control Council Law No. 10

On 20 December 1945, the four Allied Powers resolved this issue by enacting Control Council Law No. 10, which became the most important part in the creation of the US Military Tribunals at Nuremberg. In its preamble, Control Council Law No. 10 stated that this act was established ${ }^{55}$

in order to give effect to the terms of the Moscow Declaration of 30 October 1943 and the London Agreement of 8 August 1945, and the Charter issued pursuant thereto and in order to establish a uniform legal basis in Germany for the prosecution of war criminals and other similar offenders, other than those dealt with by the International Military Tribunal ...

Control Council Law No. 10 defined the jurisdiction of US Military Tribunal III and of similar military tribunals in Germany. ${ }^{56}$ Article III granted the authorisation of arresting, charging and trying war criminals to the Military Governments of each Allied Power within their zone of occupation. Article III sections (1) and (2) read as follows: ${ }^{57}$

1. Each occupying authority, within its Zone of occupation,

(a) shall have the right to cause persons within such Zone suspected of having committed a crime, including those charged with crime by one of the United Nations, to be arrested ...

(d) shall have the right to cause all persons so arrested and charged, and not delivered to another authority as herein provided, or released, to be brought to trial before an appropriate tribunal. ...

2. The Tribunal by which persons charged with offenses hereunder shall be tried and the rules and procedure thereof shall be determined or designated by each Zone Commander for his respective Zone. Nothing herein is intended to, or shall impair or limit the jurisdiction or power of any court or tribunal now or hereafter established in any Zone by the

\footnotetext{
${ }^{55}$ Control Council Law No. 101945 (US, UK, France, USSR).

${ }^{56}$ Ibid, arts I-V.

${ }^{57}$ Ibid, art III ss (1), (2).
} 
Commander thereof, or of the International Military Tribunal established by the London Agreement of 8 August 1945....

Also, the provisions of the London Agreement, of its annexed Charter and of the Moscow Declaration were made an integral part of Control Council Law No. 10. This was announced in Article I: ${ }^{58}$

The Moscow Declaration of 30 October 1943 'Concerning Responsibility of Hitlerites for Committed Atrocities' and the London Agreement of 8 August 1945 'Concerning Prosecution and Punishment of Major War Criminals of the European Axis' are made integral parts of this Law. ...

Consequently, in its judgment, US Military Tribunal III made clear that its creation and legal jurisdiction was based upon and limited by these statutes. In the Tribunal's opinion, the defendants were rightly accused with crimes as defined in Control Council Law No. 10 only, and it stated that this law was legally enacted by the Allied Control Council for Germany. ${ }^{59}$ In due consideration of Article 2 of the London Agreement, which provided that the Charter of the International Military Tribunal shall form an integral part of the Agreement, the judgment stated: ${ }^{60}$

Thus, it appears that the indictment is drawn under and pursuant to the provisions of Control Council Law No. 10 ... that ... expressly incorporates the London Agreement as a part thereof, and that the IMT Charter is a part of the London Agreement.

Furthermore, Control Council Law No. 10 specified four wide ranging statutory offences, namely (a) crimes against peace; (b) war crimes; (c) crimes against humanity; and (d) membership in criminal organisations. ${ }^{61}$ The Tribunal in the Justice Case had to deal with crimes of the categories (b), (c) and (d) only. ${ }^{62}$ Article II section (1) of Control Council Law No. 10 defined these crimes as follows: ${ }^{63}$

(b) War Crimes. Atrocities or offences against persons or property constituting violations of the laws or customs of war, including but not

\footnotetext{
${ }^{58}$ Ibid, art I.

${ }^{59}$ Justice Case, above n 9, 956-957.

${ }^{60}$ Ibid.

${ }^{61}$ Control Council Law No. 10 1945, above n 55, art II s (1).

${ }^{62}$ Justice Case, above n 9, 957.

${ }^{63}$ Control Council Law No. 10 1945, above n 55, art II s (1).
} 
limited to, murder, ill treatment or deportation to slave labour or for any other purpose, of civilian population from occupied territory, murder or ill treatment of prisoners of war or persons on the seas, killing of hostages, plunder of public or private property, wanton destruction of cities, towns or villages, or devastation not justified by military necessity.

(c) Crimes against Humanity. Atrocities and offences, including but not limited to murder, extermination, enslavement, deportation, imprisonment, torture, rape, or other inhumane acts committed against any civilian population , or persecutions on political, racial or religious grounds whether or not in violation of the domestic laws of the country where perpetrated.

(d) Membership in categories of a criminal group or organization declared criminal by the International Military Tribunal.

Hence, Control Council Law No. 10 stipulated not only the formal jurisdiction of US Military Tribunal III but also the substantive criminal law itself, which had to be applied in the Justice Trial. For this reason, Control Council Law No. 10 was the legal basis not only for the creation, but also for the decisions, of US Military Tribunal III.

(e) Ordinance No. 7 of the US Military Government for Germany

With the establishment of Control Council Law No. 10, the zone commanders of each Allied Power were authorised to designate tribunals for the trial of offences hereunder and to determine the rules and procedure of these bodies. $^{64}$

Interestingly enough, each of the four authorities over the separate zones adopted their own method of ascertaining, bringing to trial and trying the persons in their zone believed to be guilty of war crimes. ${ }^{65}$ Furthermore, the definitions of crime in the four zones were widely different. For example, Control Council Law No. 10 was made applicable in the American

\footnotetext{
${ }^{64}$ Maugham, above n 49, 87.

${ }^{65}$ Ibid, 19.
} 
but not in the British zone of occupation. ${ }^{66}$ The British Military Government did not operate under the rules of Control Council Law No. 10 but under a Royal Warrant from 14 June 1945, which limited the crimes for which persons in the British zone could be tried to violations of the laws and usages of war, excluding crimes against peace and crimes against humanity. ${ }^{67}$

However, on 18 October 1946, the US Military Government enacted Ordinance No. 7 "for the organization and powers of certain military tribunals" ${ }^{\prime 68}$, and to implement the rules of Control Council Law No. 10 within the American zone of occupation. Article II section (a) of the Ordinance said: ${ }^{69}$

Pursuant to the powers of the Military Governor for the United States Zone of Occupation within Germany and further pursuant to the powers conferred upon the Zone Commander by Control Council Law No. 10 and Article 10 and 11 of the Charter of the International Military Tribunal annexed to the London Agreement of 8 August 1945 certain Tribunals to be known as 'Military Tribunals' shall be established hereunder.

Accordingly, US Military Tribunal III was established on 13 February 1947 with the task to try the selected defendants for crimes listed and defined in Article II of Control Council Law No. $10{ }^{70}$ Article I of Ordinance No. 7 explicitly recognised these crimes as punishable offences. There it said: ${ }^{71}$

The purpose of this Ordinance is to provide for the establishment of military tribunals which shall have power to try and punish persons charged with offenses recognized as crimes in Article II of Control Council Law No. 10, including conspiracies to commit any such crimes. Nothing herein shall prejudice the jurisdiction or the powers of other courts established or which may be established for the trial of any such offenses.

\footnotetext{
${ }^{66}$ Ibid.

${ }^{67}$ Ibid, 20. Maugham stated further that "certain persons however were charged before Control Commission Courts for 'Crimes against Humanity' committed against Allied nationals". Ibid, 20; See also Bassiouni, above n 4, 533-534.

${ }^{68}$ Military Ordinance No. 71946 (US), art I.

${ }^{69}$ Ibid, art II s (a).

${ }^{70}$ Justice Case, above n 9, 1189.

${ }^{71}$ Military Ordinance No. 7 1946, above n 68, art I.
} 
Ordinance No. 7 also regulated the law of procedure, what in fact was an adoption of the rules of procedure as defined in the London Agreement and Control Council Law No. 10. ${ }^{72}$ These rules were solely based on the common law tradition, what meant that instead of the inquisitorial system used in German criminal law, the adversarial system used in the United States was taken. ${ }^{73}$ Thus, it was not on the Tribunal to explore the truth (like in the inquisitorial system), but the statements and pleadings by the parties became the basis of the proceeding (like in the adversarial system). ${ }^{74}$

(f) Judgment of the International Military Tribunal

According to the Charter annexed to the London Agreement, the International Military Tribunal was created. The major war criminals of Nazi Germany were tried and sentenced with judgment from 30 September and 1 October 1946 by this Tribunal, which consisted of judges from all four Allied Powers, namely the United States, Great Britain, France and the Soviet Union. ${ }^{75}$ Control Council Law No. 10 referred directly to this judgment. For example, Article II section (1) (d) of Control Council Law No. 10 stated that "each of the following acts is recognized as a crime: ... Membership in categories of a criminal group or organization declared criminal by the International Military Tribunal." ${ }^{, 76}$

Furthermore, Article X of Ordinance No. 7 stipulated that statements and conclusions of the International Military Tribunal were binding for the subsequent US military tribunals. Article X reads as follows: ${ }^{77}$

\footnotetext{
72 Frank M Buscher The U.S. War Crimes Trials Program in Germany, 1946-1955 (Greenwood Press, New York, 1989) 31.

${ }^{73}$ Baestlein, above n 12,11 .

${ }^{74}$ Ibid; See also Antonio Cassese International Criminal Law (2 ed, Oxford University Press, Oxford, 2008) 355-356.

${ }^{75}$ Woetzel, above n 14, 7.

${ }^{76}$ Control Council Law No. 10 1945, above n 55, art II s (1) (d).

${ }^{77}$ Military Ordinance No. 7 1946, above n 68, art X.
} 
The determination of the International Military Tribunal in the judgment in Case No. 1 that invasions, aggressive acts, aggressive wars, crimes, atrocities or inhumane acts were planned or occurred, shall be binding on the tribunals established hereunder and shall not be questioned except insofar as the participation therein or knowledge thereof by any particular person may be concerned. Statements of the International Military Tribunal in the judgment in Case No. 1 constitute proof of the facts stated, in the absence of substantial new evidence to the contrary.

Hence, the judgment of the International Tribunal was also part of the legal basis of US Military Tribunal III.

2 Compatibility with existing international law and customs

(a) Non-applicability of Hague Convention No. IV (Laws and Customs of War on Land)

The international conferences of 1899 and 1907 in The Hague in the Netherlands established rules of warfare between the signatory nations. ${ }^{78}$ Hague Convention No. IV was created, after minor revisions on the text from 1899, at the second conference providing laws and customs of war on land. ${ }^{79}$ It consisted of nine articles in the main text and 56 annexed articles, and it was enacted with agreement from 18 October $1907 .{ }^{80}$ At both conferences, Germany, Austria-Hungary, France, Great Britain, Russia and the United States were among the countries which signed the Convention. ${ }^{81}$

Article 2 of Hague Convention No. IV stated: ${ }^{82}$

\footnotetext{
78 “Hague Convention” www.britannica.com (last accessed 16 March 2010). ${ }^{79}$ Ibid.

${ }^{80}$ See generally Hague Convention Respecting the Laws and Customs of War on Land (Hague IV) (18 October 1907).

${ }^{81}$ General Report of the United States Commission to the Peace Conference of The Hague (31 July 1899).

${ }^{82}$ Hague Convention Respecting the Laws and Customs of War on Land (Hague IV), above n 80 , art 2.
} 
The provisions contained in the Regulations referred to in Article 1, as well as in the present Convention, do not apply except between Contracting Powers, and then only if all the belligerents are parties to the Convention.

Hence, Hague Convention No. IV was valid and binding international law between Germany and the four Allied Powers in 1947. However, it did not apply to post-war Germany because of Article 42 of the annex to the Convention. Therein it said: "Territory is considered occupied when it is actually placed under the authority of the hostile army. The occupation extends only to the territory where such authority has been established and can be exercised." 83

John H E Fried looked at this rule in regard to the existing situation in Germany after World War II and, in 1946, he stated: ${ }^{84}$

The provisions of the Hague Regulations restricting the rights of an occupant refer to a belligerent, who, favored by the changing fortunes of war, actually exercises military authority over enemy territory and thereby prevents the legitimate sovereign -who remains the legitimate sovereign- from exercising his full authority. The Regulations draw important legal conclusions from the fact that the legitimate sovereign may at any moment himself be favored by the changing fortunes of war, reconquer the territory and put an end to the occupation. ... In other words, the Hague Regulations think of an occupation which is a phase of an as yet undecided war. Until May 7, 1945, the Allies were belligerent occupants in the then occupied parts of Germany, and their rights and duties were circumscribed by the respective provisions of the Hague Regulations. As a result of the subjugation of Germany the legal character of the occupation of German territory was drastically changed. The occupants do no longer act in lieu of the 'legtimate sovereign'. They themselves exercise sovereignty. ...

This interpretation by Fried is viable but not the only possible argument. However, if one looks at Article 42 related to the overall structure of Hague Convention No. IV, it becomes obvious that only belligerent

\footnotetext{
${ }^{83}$ Ibid, Annex art 42.

${ }^{84}$ John H E Fried "Transfer of Civilian Manpower from Occupied Territory" (1946) 40 Am J Int'1 L 303, 327.
} 
occupations, meaning the invasion of an army into the territory of another country during acts of war, ${ }^{85}$ can be meant.

This view was supported by many scholars of high standing in the field of international law, among them Hans Kelsen and Alwyn V Freeman. ${ }^{86}$ In 1947, Freeman said: ${ }^{87}$

On the other hand, a distinction is clearly warranted between measures taken by the Allies prior to destruction of the German Government and those taken thereafter. Only the former need be tested by the Hague Regulations, which are inapplicable to the situation now prevailing in Germany. Disappearance of the German State as a belligerent entity, necessarily implied in the Declaration of Berlin of June 5, 1945, signifies that a true state of war -and hence belligerent occupation- no longer exists within the meaning of international law....

This view was also supported by the International Military Tribunal. In its case against the German major war criminals, the defendants had claimed that Germany was no longer bound by the rules of Hague Convention No. IV in many of the territories occupied during the war because Germany had completely subjugated those countries and incorporated them into the German Reich, a fact which allegedly gave Germany authority to deal with the occupied territories as though they were part of Germany. ${ }^{88}$ The International Tribunal referred to the doctrine of subjugation and held that it is unnecessary to decide whether the doctrine has any application where the subjugation is the result of aggressive war. ${ }^{89}$ The reason given was significant and confirmed the interpretation of Fried and Freeman: ${ }^{90}$

The doctrine [of subjugation] was never considered to be applicable so long as there was an army in the field attempting to restore the occupied territories to their true owners, and in this case, therefore, the doctrine could not apply to any territories occupied after $1^{\text {st }}$ September, 1939.

\footnotetext{
${ }^{85}$ Justice Case, above n 9, 961.

${ }^{86}$ Ibid, 962.

${ }^{87}$ Alwyn V Freeman "War Crimes by Enemy Nationals Administering Justice in Occupied Territory” (1947) 41 Am J Int'l L 579, 605.

${ }^{88}$ International Military Tribunal I, above n 1, 254.

${ }^{89}$ Ibid.

${ }^{90}$ Ibid.
} 
US Military Tribunal III referred to this statement and concluded as follows: ${ }^{91}$

The clear implication from the foregoing is that the Rules of Land Warfare apply to the conduct of a belligerent in occupied territory so long as there is an army in the field attempting to restore the country to its true owner, but that those rules do not apply when belligerency is ended, there is no longer an army in the field, and, as in the case of Germany, subjugation has occurred by virtue of military conquest.

Hence, in the case of post-war Germany, after the unconditional surrender of the German armed forces on 8 May 1945, the status of belligerent occupation of the German territory by the Allied Powers did not exist anymore and, therefore, Hague Convention No. IV could not apply to Germany after 8 May 1945.

Although the reasons differ, all opinions described above share the same point of view, which is that the written rules set out in Hague Convention No. IV did not apply to post-war Germany and, therefore, the enacted laws of the Allied Powers, especially Control Council Law No. 10 and Ordinance No. 7, did not have to match the criteria of the Hague Convention.

(b) The issue of Germany's remaining sovereignty

In general, the sovereignty of a state is defined as follows: ${ }^{92}$

Sovereignty is the power of a state to do everything necessary to govern itself, such as making, executing, and applying laws; imposing and collecting taxes; making war and peace; and forming treaties or engaging in commerce with foreign nations.

Therefore, the power to legislate is an inseparable part of a country's sovereignty. The validity of Control Council Law No. 10 and of Ordinance

${ }_{91}^{91}$ Justice Case, above n 9, 962.

92 West's Encyclopedia of American Law 2008 "Sovereignty" http://legaldictionary.thefreedictionary.com (last accessed 16 March 2010). 
No. 7 and, with it, the right of the Allies to legislate for the German territory, was questioned throughout all Nuremberg Trials by several German writers. ${ }^{93}$ Contrary to most legal scholars in international law, those critics argued that the Allies did not have the legal authority to exercise legislative power over the German territory because, in their opinion, Germany had never lost its sovereignty after the war. ${ }^{94}$

In its judgment for the Justice Trial, US Military Tribunal III carefully considered this issue and discussed it in considerable length. Although one member of the Tribunal, Judge Blair, did not agree with the Tribunal's analysis, his final evaluation was the same, namely that the Allies truly had the right to legislate and rule for the German territory after World War II because of the unconditional surrender and the simultaneous collapse of the German Government. ${ }^{95}$

In terms of victor's justice, there are no signs that the opinions of the judges of Tribunal III were based on ideas of vengeance. Their statements in the judgment represented a critical and careful analysis of this issue based on legal theory rather than on personal feelings or emotions. Within their statements one is not able to find obviously subjective opinions about Nazis and Nazi Germany. By replacing the words Germany and Germans with other names of nations and nationals, the judgment could just as well have been made for other countries where a similar post-war situation could have occurred.

(i) View of US Military Tribunal III

In all subsequent trials at Nuremberg, the defence had claimed that the jurisdiction of the Allied tribunals violated Germany's sovereignty. In the Justice Case, Tribunal III responded vigorously to this. In the judgment,

\footnotetext{
${ }^{93}$ Baestlein, above n 12,9 .

94 Ibid.

95 Justice Case, above n 9, 959-971, 1178-1195.
} 
two of the three judges argued that the legitimacy of the Tribunal was based on the legitimacy of the Allied defeat of Germany. The judgment referred to the Berlin Declaration from 5 June 1945 and explained: ${ }^{96}$

\begin{abstract}
The unconditional surrender of Germany took place on 8 May 1945. The surrender was preceded by the complete disintegration of the central government and was followed by the complete occupation of all of Germany. There were no opposing German forces in the field; the officials who during the war had exercised the powers of the Reich Government were either dead, in prison, or in hiding. On 5 June 1945 the Allied Powers announced that they 'hereby assume supreme authority with respect to Germany, including all the powers possessed by the German Government, the High Command, and any state, municipal or local government or authority,' and declared that 'there is no central government or authority in Germany capable of accepting responsibility for the maintenance of order, the administration of the country, and compliance with the requirements of the victorious powers.' ...
\end{abstract}

Consequently, the Tribunal then drew a conclusion that Germany had lost its sovereignty to the Allies because, after the complete disintegration of the German Government followed by the unconditional surrender of the German armed forces and the occupation of the German territory, there was an inevitable necessity for the Allies to exercise supreme governmental powers not only for administrative but, in the first place, also for humanitarian reasons. In the judgment it is stated as follows: ${ }^{97}$

It is this fact of the complete disintegration of the government in Germany, followed by unconditional surrender and by occupation of the territory, which explains and justifies the assumption and exercise of supreme governmental powers by the Allies. The same fact distinguishes the present occupation of Germany from the type of occupation which occurs when, in the course of actual warfare, an invading army enters and occupies the territory of another state, whose government is still in existence and is in receipt of international recognition, and whose armies, with those of its allies, are still in the field. In the latter case, the occupying power is subject to the limitations imposed upon it by the Hague Convention and by the laws and customs of war. In the former case (the occupation of Germany) the Allied Powers were not subject to

\footnotetext{
96 Ibid, 959.

${ }^{97}$ Ibid, 960.
} 
those limitations. By reason of the complete breakdown of government, industry, agriculture, and supply, they were under an imperative humanitarian duty of far wider scope to reorganize government and industry and to foster local democratic governmental agencies throughout the territory.

Hence, in the view of US Military Tribunal III, after the war Germany was not a sovereign state anymore and Control Council Law No. 10, as well as other codes enacted by the Military Governments, was a valid law because the Allies were the new holders of governmental power in Germany. However, the Tribunal seemed to be inconsistent in its explanation. In the judgment, the Tribunal contradicted itself within different sections. At one place it is stated: ${ }^{98}$

International law is not the product of statute for the simple reason that there is as yet no world authority empowered to enact statutes of universal application. International law is the product of multipartite treaties, conventions, judicial decisions and customs which have received international acceptance or acquiescence.

This means that, in the view of the Tribunal, there has never been an international legislature. Yet, at another place, the judgment stated as follows: ${ }^{99}$

Since the IMT Charter and C. C. Law 10 are the products of legislative action by an international authority, it follows of necessity that there is no national constitution of any one state which could be invoked to invalidate the substantive provisions of such international legislation.

Although the judgment additionally explained that Control Council Law No. 10 "may be deemed to be a codification rather than original substantive legislation" $" 100$, this statement has to be seen as conflicting with the first one. Eventually, at still another place, the judgment stated: ${ }^{101}$

In its aspect as a statute defining crime and providing punishment the limited purpose of C. C. Law 10 is clearly set forth. It is an exercise of

\footnotetext{
98 Ibid, 974-975.

${ }^{99}$ Ibid, 965.

${ }^{100}$ Ibid, 966.

${ }^{101}$ Ibid, 965.
} 
supreme legislative power in and for Germany. It does not purport to establish by legislative act any new crimes of international applicability.

However, these conflicting conclusions do not need to be discussed further as the judgment itself offered an explaining statement additionally: ${ }^{102}$

For our purposes, however, it is unnecessary to determine the present situs of 'residual sovereignty'. It is sufficient to hold that, by virtue of the situation at the time of unconditional surrender, the Allied Powers were provisionally in the exercise of supreme authority, valid and effective until such time as, by treaty or otherwise, Germany shall be permitted to exercise the full powers of sovereignty. We hold that the legal right of the four Powers to enact C. C. Law 10 is established and that the jurisdiction of this Tribunal to try persons charged as major war criminals of the European Axis must be conceded.

Thus, in the end, it remains that US Military Tribunal III held the opinion that Control Council Law No. 10 was a valid act, based either on the overtaking of the German legislative power by the Allies or in another way after the unconditional surrender on 8 May 1945. According to the Tribunal's judgment, Germany lost its full powers of sovereignty because of the complete breakdown of political and civil structures within Germany after the war.

(ii) Dissenting view of Judge Blair

Judge Blair evaluated the issue of Germany's legal status in a different way. Although he agreed that the Allies had the legitimacy to enact Control Council Law No. 10 and the Tribunal had the legal jurisdiction to carry out the trial, he disagreed with the explanation for it. He argued: ${ }^{103}$

No authority or jurisdiction to determine the question of the present status of belligerency of the occupation of Germany has been given this

${ }^{102}$ Ibid, 963.

${ }^{103}$ Ibid, 1178-1179. 
Tribunal. This question of present belligerency of occupation rests solely within the jurisdiction of the military occupants and the executives of the nations which the members of the Allied Control Council represent. ... If, however, any possible questions are here present for determination with respect to (1) the character of the present status of occupation of Germany; and (2) the present status of belligerency, such questions can only relate to the rights of the victorious belligerent to exercise control over Germany. Such matters as regard the American Zone are controlled by both the written and unwritten laws, rules, and customs of warfare and by the rights and obligations of a victorious occupant under international law.

Accordingly, he referred to existing US rules, especially to several articles of the Basic Field Manual on Rules of Land Warfare, which were published in 1940 by the Judge Advocate General of the US Army: ${ }^{104}$

Under the foregoing rules of military occupation [Articles 273 to 275, 285, and 286 of the United States Basic Field Manual on Rules of Land Warfare], there is no rule which would, because of the unconditional surrender of the German armed forces, transfer the sovereignty of Germany to the Allied occupants, or to either of them, in their respective zones of occupation.

Certainly, the binding nature of these purely US rules is questionable but Judge Blair also referred to existing international law: ${ }^{105}$

It may here be pointed out that the report of 1919 by the Commission on the Responsibility of the Authors of War and Enforcement of Penalties $\left[{ }^{106}\right]$ lists among other war crimes in violation of international law or of the laws and customs of land warfare, '(10) the usurpation of sovereignty during military occupation.'

Hence, with respect to both of these regulations, he concluded that Germany remained fully sovereign after 8 May 1945, and the Allies exercised their governmental power only provisionally until Germany,

\footnotetext{
${ }^{104}$ Ibid, 1179-1180.

${ }^{105}$ Ibid, 1181.

${ }^{106}$ The Commission on the Responsibility of the Authors of the War and on the Enforcement of Penalties was established after World War I in January 1919. It consisted of 15 representatives from ten states and had the task to report on the responsibility for the start of the war, violations of the laws of war and the establishment of an appropriate tribunal to held trials of such violations. Kate Bicknell "Is every International Criminal Law Trial Really a Show Trial?” (LLM Research Paper, Victoria University of Wellington, 2007) 14.
} 
purged from influences from Nazism and militarism, could take back its place in the world community: ${ }^{107}$

\begin{abstract}
There has been no act or declaration of the Allied Powers, either before or since their occupation of Germany under the terms of the unconditional surrender, which could possibly be construed as showing that they intend by the subjugation and occupation of Germany to transfer her sovereignty to themselves. To the contrary every declaration that has been made by the Allied Powers with respect to their occupancy of Germany and the enactment of laws for her control during the occupation has emphasized the fact that the ultimate purpose of such occupancy is to destroy the Nazi form of government and militarism in Germany so that as thus extirpated from these influences she may take her place in the comity of the nations of the world.
\end{abstract}

Consequently, he explained that the jurisdiction and power of Tribunal III to try and punish war criminals was given by "established international law relating to warfare" already; ${ }^{108}$ the Allied laws, additionally, determined the punishable crimes and the rules of procedure only. $^{109}$

Furthermore, Blair analysed Control Council Law No. 10 and Ordinance No. 7 with their referrals to the parts of the Moscow Declaration, the London Agreement and the Charter of the International Military Tribunal, which expressed the Allied concept to try and punish the German war criminals and which authorised the zone commanders to establish military tribunals, and declared: ${ }^{110}$

\footnotetext{
As so created and established this and other similar military tribunals are international in character and jurisdiction. ... The jurisdiction and power of this and similar tribunals to try and punish war criminals find full support in established international law relating to warfare. This law is that during hostilities and before their formal termination belligerents have concurrent jurisdiction over war crimes committed by the captured enemy persons in their territory or against their nationals in time of war. Accordingly, it has been generally recognized that belligerents during the
}

${ }^{107}$ Justice Case, above n 9, 1182.

${ }^{108}$ Ibid, 1189.

${ }^{109}$ Ibid, 1186-1190.

${ }^{110}$ Ibid, 1189-1190. 
war may legitimately try and punish enemy persons charged with infraction of the rules of war, if the accused is a prisoner of war and if the act charged has been made a penal offense by the generally accepted laws and customs of war. In such cases the accused usually is tried before the court, commission, or tribunal set up by and adjudged in accordance with the laws and procedure of the victor. After armistice or peace agreement the matter of punishment of war crimes is determined by the terms thereof.

According to this, Blair referred to an article about the London Agreement by Lord Chief Justice Wright published in 1946. Therein, Wright stated that the listed crimes in the Agreement "are not crimes because of the agreement of the four Governments, but that the Governments have scheduled them as coming under the jurisdiction of the Tribunal because they are already crimes by existing law."111

Blair then concluded that similar holdings can be made for Control Council Law No. 10 as it recognised the same basic crimes and, therefore, Control Council Law No. 10 was a valid act because it was ${ }^{112}$

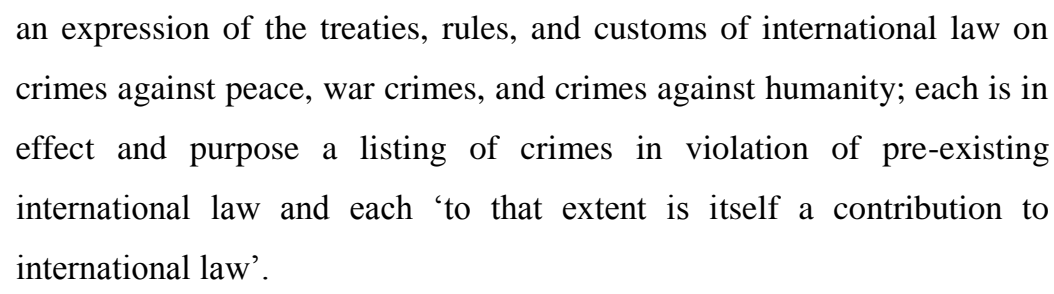

In stating that, Blair referred to the Hague Conventions of 1899 and 1907, the Peace Conference of 1919 and the Versailles Treaty, the various treaties of mutual guarantee, arbitration and nonaggression and the KellogBriand Pact of $1928 .{ }^{113}$

Finally, Blair's opinion can be summarised as follows: although Germany did not lose its sovereignty after 8 May 1945, the jurisdiction of the Tribunal as well as the legitimacy of the Allies to rule about the German territory was granted by treaties, rules and customs of existing international law.

\footnotetext{
${ }^{111}$ Quincy Wright "War Crimes under International Law" (1946) 62 LQR 40, 41

112 Justice Case, above n 9, 1191.

113 Ibid.
} 
(iii) Evaluation

According to the German historian Klaus Baestlein, the four Allied Powers officially took over the state authority in Germany with the Berlin Declaration on 5 June $1945 .{ }^{114}$ It was a novelty that neither a peace agreement nor an annexation followed but, in fact, the state population and the state territory continued to exist while the Allies exercised the state authority. $^{115}$

Baestlein expressed a view, which was supported by the vast majority of international legal experts since World War II. However, many German jurists disagreed and argued that the Allies did not become the holders of the state authority, but only provisional administrators in a fiduciary or managing sense, which implied that they were not legitimated to enact new laws and rules for the German territory. ${ }^{116}$

Later on, even the Governments of the Federal Republic of Germany adopted this way of thinking and acted like the legal successor of the Third Reich with exclusive power of representation. ${ }^{117}$ A final clarification of this issue did not happen until the signing of the two-plus-four treaties on the occasion of the German unification in 1990, in which the Federal Republic of Germany officially accredited the legal takeover of the state authority by the Allies through the Berlin Declaration on 5 June $945 .{ }^{118}$

However, in my opinion, the German critics cannot be taken seriously because after World War II the whole German society had collapsed. There was no functioning government on state or local level, no functioning administration and no functioning jurisdiction. The existing laws of Nazi Germany were obviously inappropriate for a new start, and the

\footnotetext{
${ }^{114}$ Baestlein, above n 12,9 .

${ }^{115}$ Ibid.

${ }^{116}$ Ibid, 9-10.

${ }^{117}$ Ibid, 10.

${ }^{118}$ Ibid.
} 
majority of German jurists in 1945 were either loyal Nazis or sympathisers. According to Nathan Stoltzfus and Henry Friedlander, an estimated 90 per cent of all German judicial officials had been members of the Nazi Party. ${ }^{119}$

Ingo Muller, additionally, gives the examples of Westphalia, were 93 per cent of the court personnel had been members of the Nazi Party or its subsidiary organisations, Bamberg, where 302 out of 309 members of the Court of Appeal had been in the Party, and Schweinfurt, where the number of Party members was 100 per cent. ${ }^{120}$ Hence, in Mueller's view: "The unconditional surrender of the Great German Reich not only brought an end to institutionalized terror; it brought an end to the entire judicial system."

Therefore, at the time, there was no other option than the establishment of a new legal order by the Allies. In the end, it does not matter whether the Allies did this by overtaking Germany's full sovereignty or by ruling on a provisional basis only. It is a matter of fact that the German Reich disappeared after the war and, in 1947, Germany had lost its practical sovereignty because there was no self determination possible anymore.

In terms of victor's justice, this means that the accusation of an illegal overtaking of Germany's state authority by the Allies is proved wrong for the primary reason that there would have been no alternative besides abandoning the German people to their fate, which would probably have been meant chaos and death.

\footnotetext{
${ }^{119}$ Nathan Stoltzfus and Henry Friedlander "Introduction: Nazi Crimes and the Law" in Nathan Stoltzfus and Henry Friedlander (eds) Nazi Crimes and the Law (Cambridge University Press, New York, 2008) 8.

${ }^{120}$ Ingo Mueller Hitler's Justice: The Courts of the Third Reich (Harvard University Press, Cambridge, 1991) 202.

${ }^{121}$ Ibid, 201.
} 
(c) The implementation of a purely US court

As early as January 1947, three months after the rulings of the International Military Tribunal, the US Government rejected the official appeal from the French authorities for a second Allied tribunal. ${ }^{122}$ The reason was that the American authorities, especially the US Chief Prosecutor for the first trial and one of the creators of the London Agreement, Robert H Jackson, disliked the methods of the Soviet prosecution and favoured trials by US tribunals only. ${ }^{123}$

Thus, on 14 February 1947, the Military Governor for the American occupation zone in Germany, Lieutenant General Clay, issued General Order No. 11, which constituted US Military Tribunal III to try high ranked German jurists. ${ }^{124}$ Based on Ordinance No. 7, this order named the members of the Tribunal and the place of trial at Nuremberg. ${ }^{125}$ Although Article III section (1) (d) of Control Council Law No. 10 contained the possibility of trying the defendants in front of a German court, the US authorities made no use of it in this case. ${ }^{126}$

Hence, the accusation of victor's justice was brought up soon. The mostly German critics argued that the judges of the Nuremberg Tribunals were not in a position to judge the German problem objectively, because they were citizens of a victorious state and, therefore, were not free from national resentment and passion. ${ }^{127}$ Also, some German lawyers asserted that for victors to try the defeated was in contradiction to international law. ${ }^{128}$ Accordingly, two major arguments were brought up: one was based

\footnotetext{
${ }^{122}$ Friedman, above n 2, 77.

${ }^{123}$ Ibid, 76-77.

${ }^{124}$ Justice Case, above n 9, 7.

125 Ibid.

${ }^{126}$ Control Council Law No. 10 1945, above n 55, art III s (1) (d).

127 Karl-Heinz Lueders "The Nuremberg Judgment: Penal Jurisdiction over Citizens of Enemy States" in Wilbourn E Benton and Georg Grimm (eds) Nuremberg: German Views of the War Trials (Southern Methodist University Press, Dallas, 1955) 129.

${ }^{128}$ Ibid.
} 
on an historical background; the other was related to the principle of separation of powers.

(i) Historical experience

The first argument was a weak one and related to the Acts of State doctrine, which ${ }^{129}$

is based on the idea that an individual cannot be made responsible for an act which he performed as an instrument or 'organ' of his state, since responsibility for such violations rests on the 'collectivity of individuals,' which is the state.

It was claimed that war crimes trials historically were supposed to be held by national courts of the defendants' nationality only. ${ }^{130}$ Before World War I, the German opinion, strongly supported by the Reichsmilitaergericht (Reich Military Tribunal), was that “only the soldier's native state possesses penal jurisdiction over those crimes which he committed before he was taken prisoner, even if those crimes were directed against the enemy state or its citizens." 131 This view was also supported by Article 3 of the Hague Convention of 1907, which said that the state "shall be responsible for all acts committed by persons forming part of its armed forces." 132

In contrast, British thoughts on this point were different even before World War I, as British courts held that they had jurisdiction over such cases. ${ }^{133}$ Therefore, after World War I, at the Peace Conference in Paris in 1919, the Commission on the Responsibility of the Authors of the War and on Enforcement of Penalties was established to find a method for action against enemy nationals accused of having committed war crimes. ${ }^{134}$

\footnotetext{
${ }^{129}$ Woetzel, above n 14, 68.

${ }^{130}$ See generally Lueders, above n 127, 127-135.

${ }^{131}$ Ibid, 129.

132 Hague Convention Respecting the Laws and Customs of War on Land (Hague IV), above $\mathrm{n} 80$, art 3 .

${ }^{133}$ Woetzel, above n 14, 26.

${ }^{134}$ Ibid, 27.
} 
In many ways, this Paris Conference resembled the London Conference in August 1945. ${ }^{135}$ Although favoured by the French and British Government, the American delegates mentioned that an international tribunal would not have a current penal law which it could apply, because no regulation of international law and no state treaty rendered the violations of the customs of war and the law of war an international crime which could be punished. ${ }^{136}$ This view was closer to the German opinion than to the views of the other Allies. As a result, the idea of an international tribunal was finally overthrown and the extradition of war criminals to the military jurisdiction of the defeated enemy power was decided. ${ }^{137}$

Unlike the London Conference after World War II, the Paris Conference was supposed to work out peace treaties between the Allies and the defeated nations. In the case of Germany, the result was the Treaty of Versailles from 28 June $1919 .{ }^{138}$ It was not a real agreement but a directive of provisions to the Government of the new German Weimar Republic. ${ }^{139}$

However, although Articles 228 to 230 of the treaty recognised the right of the Allied and Associated Powers to try persons accused of violating the laws and customs of war before military tribunals and obliged the German Government to hand over these persons and furnish all documents and materials that could be used as evidence, ${ }^{140}$ these punitive provisions were never realised in the sense that they were intended. ${ }^{141}$

In February 1920, a list with 896 names of German nationals who were to be handed over for trial was submitted to the German delegate at the Paris Conference, Baron von Lersner. ${ }^{142}$ The list included high ranking officials like Chancelor Bethman, Marshal Hindenburg, Marshal Ludendorff

\footnotetext{
135 Ibid.

${ }^{136}$ Lueders, above n 127, 127.

${ }^{137}$ Ibid, 128.

${ }^{138}$ Woetzel, above n 14, 30.

${ }^{139}$ See generally Treaty of Versailles (28 June 1919).

${ }^{140}$ Ibid, arts 228-230.

${ }^{141}$ Woetzel, above n 14, 30-31.

142 Ibid, 31.
} 
and the Imperial Crown Prince. ${ }^{143}$ Baron von Lersner was indignant at this and resigned in protest. ${ }^{144}$

The list was then handed to the German Government, which from then on made every effort to prevent the handing over of the designated persons. ${ }^{145}$ After discussion, the Allies finally declared themselves willing to accept the proposal of Germany's Government to try these individuals themselves at the Reich's Supreme Court in Leipzig. ${ }^{146}$

The outcome was disastrous. From an abridged list of 45 names the Allies had submitted to the Germans, only twelve persons were tried and six were convicted and sentenced to terms of imprisonment from two months to four years. ${ }^{147}$ In the following years, 1,744 preliminary investigations were initiated by the German prosecution, but only 13 proceedings led to an indictment at the Leipzig Supreme Court. ${ }^{148}$

The Allies protested strongly and announced that they will conduct these and further trials by themselves according to Article 228 to 230 of the Treaty of Versailles, but they did not again request the extradition of the accused persons. ${ }^{149}$ In the end, very few trials were held against defendants in absentia in Belgium and France. ${ }^{150}$ The German Emperor Wilhelm II, who had fled to the Netherlands after the war, was never extradited and died there in $1941 .^{151}$

Thus, it is obvious that this bad experience of the Leipzig Trials had caused the Allies of World War II, which were, except for the Soviet Union, the same as in World War I, to arrange the war crimes trials against the German Nazis under their own aegis.

Furthermore, it has to be taken into consideration that the supporters of the German critics on the purely US tribunals tended to forget historical

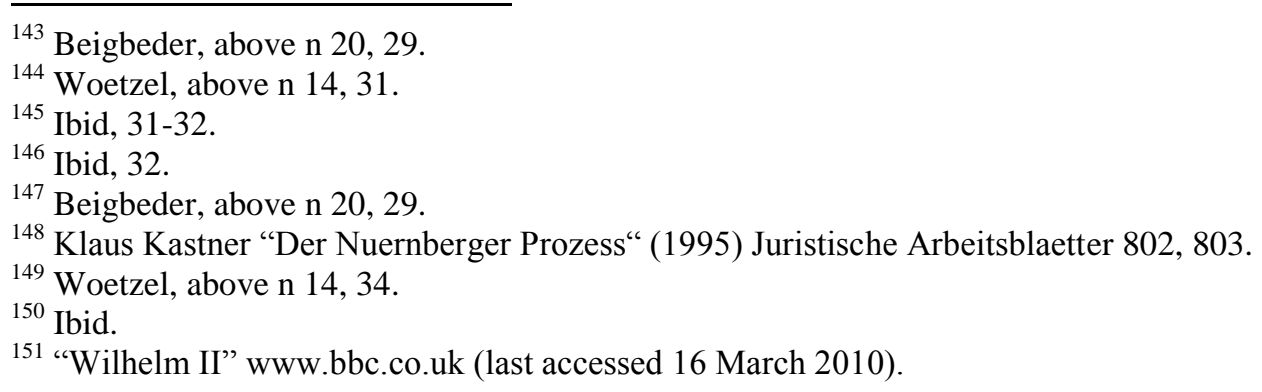


facts. Although the German Military Penal Code during World War I expressed a different view, the German Reich and its military tribunals had also tried Allied prisoners of war who were guilty of disregarding the Hague Convention on land warfare during the time prior to their seizure. ${ }^{152}$ This was in accordance with the practice of the Allies, which was legal not only in England but in the whole Anglo-Saxon sphere of law already before World War I. ${ }^{153}$

During World War II, this practice was also committed by German military courts. ${ }^{154}$ The German politician Lueders, who later on became a high ranked official in the Ministry of the Interior in West Germany, in 1946, stated as follows: ${ }^{155}$

\footnotetext{
In the same manner in which many German soldiers are today tried before English, American, French, and Russian military tribunals, many Allied soldiers were tried before German military courts a few years ago. This is easily overlooked when today the war crimes trials of the present are criticized in this country with slashing opinions.
}

Conclusively, it has to be said that the criticism of the implementation of a purely US court with arguments based on historical facts was a double-edged sword from the very beginning. One cannot argue with certain parts of history ignoring other parts, which, when highlighted, give a completely different view of the facts.

(ii) The violation of the principle of separation of powers

On 19 November 1945, all defence counsels at the trial before the International Military Tribunal made a joint application in which, among other things, the composition of the court was criticised. ${ }^{156}$ It said: ${ }^{157}$

\footnotetext{
${ }^{152}$ Lueders, above n 127, 133.

153 Ibid.

154 Ibid, 133-134.

155 Ibid.

${ }^{156}$ International Military Tribunal I, above n 1, 168-170.
} 
The Judges have been appointed exclusively by States which were the one party in this war. This one party to the proceeding is all in one: creator of the statute of the Tribunal and of the rules of law, prosecutor and judge. It used to be until now the common legal conception that this should not be so; just as the United States of America, as the champion for the institution of international arbitration and jurisdiction, always demanded that neutrals, or neutrals and representatives of all parties, should be called to the Bench.

This criticism was made in all Nuremberg Trials by the defence. It was based upon the principle of separation of powers, which generally means that the three branches of government, legislature, executive and judiciary, have to be separated from each other, and that no branch should be able to perform a function belonging to another, and no individual should hold office in more than one branch. ${ }^{158}$ In international criminal law this means that legislator, prosecutor and judge should not come from the same country. ${ }^{159}$

In the Justice Case, US Tribunal III stated explicitly that it was entitled to enforce international law, which was superior to any German law. It said: ${ }^{160}$

The Nuernberg Tribunals are not German courts. They are not enforcing German law. The charges are not based on violation by the defendants of German law. On the contrary, the jurisdiction of this Tribunal rests on international authority. It enforces the law as declared by the IMT Charter and C. C. Law 10, and within the limitations on the power conferred, it enforces international law as superior in authority to any German statute or decree.

Therefore, international law rather than German or US law was applied by the Tribunal, and the principle of separation of powers in international law should have been respected. However, it was not and, therefore, this was itself a violation of international law. The legislation in

\footnotetext{
${ }^{157}$ Ibid, 169-170.

${ }^{158}$ Bede Harris Essential Constitutional Law (2 ed, Routledge-Cavendish, London, 2004) 14.

159 Michael R Marrus The Nuremberg War Crimes Trial 1945-1946: A Documentary History (Bedford Books, Boston, 1997) 34.

${ }^{160}$ Justice Case, above n 9, 984.
} 
form of the London Agreement, Control Council Law No. 10 and Ordinance No. 7 was made by the Americans as part of the Allies or all alone, the prosecution counsel was American and all four judges were US nationals.

Hence, besides the common question why a German court was not appointed to deal with the case, it was primarily criticised that no neutral or German judges were included in the personnel of the court. ${ }^{161}$ An international representation in the Justice Case would have required the appointment of a German judge and of judges from neutral and other countries. ${ }^{162}$ However, several reasons for the decision of the US authorities against an international representation or a German court have to be taken into account:

Firstly, the experience with the disaster of the Leipzig Trials after World War I spoke against the idea that the Americans give out of hand the whole trial to the German judicature and a German court. ${ }^{163}$ Furthermore, in 1947, before the trial, nobody really knew how infiltrated the German judicature was by Nazis and Nazi ideology. As expressed by Professor Robert K Woetzel: "Eleven years of National Socialism and five years of war had reduced the German judiciary to such a feeble and corrupt state that it could not be trusted, at the outset, to resume operations." 164

Indeed, during the trial, the incredible amount of atrocities in the name of German law and the widespread of support for the Nazi ideas among German jurists came to light and, in retrospect, justified the US decision against a German court. ${ }^{165}$ Additionally, it may also have been

\footnotetext{
161 Wilbourn E Benton "Introduction" in Wilbourn E Benton and Georg Grimm (eds) Nuremberg: German Views of the War Trials (Southern Methodist University Press, Dallas, 1955) 23-24; See also Hans Ehard "The Nuremberg Trial against the Major War Criminals and International Law" in Wilbourn E Benton and Georg Grimm (eds) Nuremberg: German Views of the War Trials (Southern Methodist University Press, Dallas, 1955) 102103; and Carl Haensel "The Conclusion of the Nuremberg Trial" in Wilbourn E Benton and Georg Grimm (eds) Nuremberg: German Views of the War Trials (Southern Methodist University Press, Dallas, 1955) 190.

162 Beigbeder, above n 20, 40.

${ }^{163}$ See Part II A 2 (c) (i) Historical experience.

${ }^{164}$ Woetzel, above n 14, 84 .

${ }^{165}$ See generally Justice Case, above n 9, 311-940.
} 
problematic to find a judge who would have accepted sitting in judgment of his former colleagues. ${ }^{166}$

Secondly, as concluded above, the sovereignty of Germany in 1947 was legally exercised by the Allied Powers in their respective occupation zones. ${ }^{167}$ Therefore, even if the Tribunal did not apply German criminal law, it was appointed legally by the state authority at the time. ${ }^{168}$ Moreover, it consisted of judges who were not involved in the legislation process before; and all four members worked as civil judges in the United States and were never involved in any activities of the US authorities responsible for the German war criminals question. ${ }^{169}$ They were flown in exclusively for the trial and left Germany afterwards. ${ }^{170}$

Thirdly and most importantly, the exclusion of neutral judges, for example from the World War II neutral countries Switzerland, Sweden or Portugal, was legally irrelevant and would have made no difference to the trial because the judges, whatever their nationality was, were obliged to apply the laws of the London Agreement and its annexed Charter, Control Council Law No. 10 and Ordinance No. 7 as the legal basis of their jurisdiction. ${ }^{171}$

However, although the neutral countries may have refused to participate in the trial for the simple reason of their neutrality, ${ }^{172}$ the acceptance of the court in public opinion surely would have been enhanced if judges from neutral countries or even from Germany had been included. $^{173}$

Finally, besides the legal arguments, it cannot be overlooked that Germany practically was a collapsed society in 1947. It was still too soon

\footnotetext{
${ }^{166}$ Beigbeder, above n 20, 40.

${ }^{167}$ See Part II A 2 (b) The issue of Germany's remaining sovereignty.

168 Ibid.

${ }^{169}$ Telford Taylor Final Report to the Secretary of the Army on the Nuernberg War Crimes Trials under Control Council Law No. 10 (US Government Printing Office, Washington DC, 1949) 34-35.

${ }^{170}$ Ibid, 35.

${ }^{171}$ Benton, above n 161, 24.

172 Beigbeder, above n 20, 40

${ }^{173}$ Benton, above n 161, 24.
} 
after the war for a new and functioning judicial administration to be established and that one could speak of a denazificated judicature yet.

Nevertheless, it remains the argument that at least judges from neutral countries could have been appointed as members of the Tribunal. The counterargument that those would probably have denied their participation is a purely theoretical one, because the Americans never did ask. Therefore, although there is a consensus among international law experts as well as among German jurists that the appointed judges handled the case with real objectivity, ${ }^{174}$ one cannot deny that it makes a difference whether nationals from a victorious belligerent state or citizens of a neutral state preside over the vanquished.

\section{B The Moral Necessity of the Trial}

World War II caused over 50 million deaths, compared to World War I with ten million. ${ }^{175}$ The killings, devastations, losses and suffering in Europe were not only larger than in World War I, but they took a new dimension as a result of the Nazi racist ideology against the Jews and the Slavic peoples of Eastern Europe. ${ }^{176}$

This sick Nazi ideology was not only brutally exercised during the war in the occupied territories but also, at the same time and earlier, in Germany itself. In this, the German judiciary and most legal professionals were at least willing partners if not enthusiastic executors. ${ }^{177}$ Some authors go as far as saying that most German judges over-identified with the Nazi regime, and have seen themselves as fighters on the internal battlefront with the responsibility to punish the enemy within. ${ }^{178}$

\footnotetext{
${ }^{174}$ Lueders, above n $127,135$.

${ }^{175}$ Beigbeder, above n 20, 29.

${ }^{176}$ Ibid, 29-30.

${ }^{177}$ See generally Mueller, above n 120.

178 Douglas O Linder "The Nuremberg Trials: The Justice Trial" www.law.umkc.edu (last accessed 16 March 2010).
} 
Ingo Mueller, although controversial, estimated that 80,000 death sentences were passed by German courts during the Nazi reign from 1933 to 1945. ${ }^{179}$ This number seems small compared to the millions of victims of the SS or Gestapo, but if one looks at Germany's allies Italy and Japan, which were also ruled over by Fascist governments during this period of time, it becomes clear that this brutality was unparalleled. ${ }^{180}$ In Italy, civil courts passed only 29 death sentences in 5,319 trials and in Japan, only two persons were sentenced to death in approximately 600 trials. $^{181}$

During National Socialism, the German law was obviously transformed into an instrument of terror. This was not done against the will of the German judiciary but with its active help and support. Mueller drew the conclusion that the German judiciary was "a smoothly functioning part of the National Socialists' system of intimidation." ${ }^{182}$ German jurists first helped to transform the existing laws of the Weimar Republic, which Tribunal III described as "a civilized and enlightened system of jurisprudence" ${ }^{, 183}$, into an instrument of Nazi politics, and then executed it in a way which had never deserved to be named the enforcement of law. ${ }^{184}$

In 1945, the German law was based on a degenerated legal system with the only purpose to spread the National Socialist ideology and exterminate any existing opposition, whether for their political opinion, religious belief, race or nationality. ${ }^{185}$ Thus, it becomes clear that the Allies had to do something to make clear that the crimes, perpetrated in the name of law, could not stay unpunished.

The decision for holding trials was based on a simple reason, expressed by the US Secretary of War, Henry L Stimson, in 1947 with

\footnotetext{
${ }^{179}$ Mueller, above n 120, 196.

${ }^{180}$ Ibid, 196-197.

${ }^{181}$ Ibid, 197.

182 Ibid, 196.

${ }^{183}$ Justice Case, above n 9, 985.

${ }^{184}$ Ibid, 988.

${ }^{185}$ Ibid, 985-988.
} 
respect to the major trial, but is also applicable to the subsequent Nuremberg proceedings, especially to the Justice Trial: ${ }^{186}$

\begin{abstract}
There were three different courses open to us when the Nazi leaders were captured: release, summary punishment, or trial. Release was unthinkable; it would have been taken as an admission that there was here no crime. Summary punishment was widely recommended. It would have satisfied the immediate requirement of the emotions, and in its own rough-hewn way it would have been fair enough, for this was precisely the type of justice that the Nazis themselves had so often used. But this fact was in reality the best reason for the rejecting such a solution. The whole moral position of the victorious Powers must collapse if their judgments could be enforced only by Nazi methods. Our anger, as righteous anger, must be subject to the law. We therefore took the third course and tried the captive criminals by a judicial proceeding. We gave to the Nazis what they had denied their own opponents - the protection of the law.
\end{abstract}

The idea was also to reorient and re-educate the German people. US authorities thought that the trial-proceedings would offer a great opportunity to demonstrate the evils of totalitarianism and the virtue of democracy to the German public. ${ }^{187}$ Morally, this was a wise idea because many Germans were still in doubt whether they followed an evil ideology or only lost a war. The big advantage of a trial was to make public for the first time what really happened in the name of law during the Nazi reign, and it gave the victims a possibility to speak.

Today, the atrocities carried out by German courts before and during World War II are well known and documented because the Justice Trial brought it to light. Nobody knows what would have happened to Nazi law documents if they were not used as evidence for the trial immediately after the war. The importance of a trial in regard to these aspects is best expressed by the words of Hans Ehard, Bavarian Prime Minister and Minister of Justice in the German Federal Parliament between 1946 and 1966, in an

\footnotetext{
${ }^{186}$ Henry L Stimson “The Nuremberg Trial: Landmark in Law" (1947) 25 Foreign Aff 179, 179-180.

${ }^{187}$ Buscher, above n 72, 2.
} 
article he wrote as a critique of the proceedings at the International Military Tribunal: ${ }^{188}$

\begin{abstract}
The blush of shame must rise in the face of every German if he hears the incontrovertible proof thereof and sees how cowardly cruelty, currish fealty, insane obsession debased honor and humanity and forfeited the German reputation. One would like to tell every German to read these documents, particularly those people who forget too soon and would like to avert their eyes from the horrors of the near past.
\end{abstract}

Finally, a last moral aspect in favour of a trial has to be seen in the international law novelty to punish so called desk perpetrators. According to Helmut Kramer, the jurists of the Third Reich represented this type of criminals at best. ${ }^{189} \mathrm{He}$ describes desk perpetrators as people which have built up a remarkable distance to the execution of the crime itself and, as a matter of fact, in nearly all cases neither the judges of the Reich People's Court nor the judges of the Special Courts were present at the execution of death sentences they had passed. ${ }^{190}$ To try those persons for the first time in history was not only a way to deal with the Nazi past, but an opportunity to show that in the future everybody, even when obliged by his own government, has to be responsible for his or her actions to the world community.

In summary, for me, it is obvious that a trial against German jurists and the German judiciary after World War II was absolutely necessary from a moral point of view. Alternatives like leaving it with the German post-war judiciary, summary punishment or doing nothing were unthinkable for the shown reasons. The atrocities committed by German courts in the name of law needed a strong response and reaction by the world community to establish and renew values of morality and ethics not only in Germany but worldwide. A trial open to public view was the best way to answer.

\footnotetext{
${ }^{188}$ Ehard, above n $161,85$.

${ }^{189}$ Helmut Kramer Plaedoyer fuer ein Forum zur juristischen Zeitgeschichte (WMIT Druck und Verlags GmbH, Bremen, 1998) 14.

${ }^{190}$ Ibid, 14-15.
} 


\section{Conclusion}

It remains that only one issue could be seen as a violation of international law here and, therefore, could give support for the reproach of victor's justice: the violation of the principle of separation of powers.

US Military Tribunal III was established as a war crimes tribunal with the authority to apply international law, but all four judges were citizens of one country. Moreover, this country was not a neutral state but a victorious belligerent. American judges applied international law against non-American citizens and, therefore, the Tribunal's decision for many people has the stigma of vengeance.

No doubt, in public opinion it would have been better if neutral judges were on the bench or German judges were included, but it is questionable if this would have been a real possibility according to the existing situation after the war. However, only the exclusion of neutral judges I would evaluate as a minor failure. The exclusion of German jurists was absolutely understandable as, in 1947, it was not clear at all which judges from German courts were morally and personally adequate for such an important trial.

Furthermore, it has to be considered that international law generally recognises the right of the victorious belligerent to judge over the citizens of the defeated state. ${ }^{191}$ The German philosopher Karl Jaspers stated with respect to the trial at the International Military Tribunal: "The trial is due to the fact that we did not free ourselves from the criminal regime but were liberated by the Allies." ${ }^{\prime 192}$ The German historian Golo Mann stated a little bit more soberly: "Sieger-Justiz ohne Zweifel und dadurch beeintraechtigt, dass nach den 'Kriegsverbrechen' der Sieger niemand fragen durfte; aber

\footnotetext{
${ }^{191}$ Lueders, above n 127, 134.

192 Karl Jaspers "The Question of German Guilt" in Guenael Mettraux (ed) Perspectives on the Nuremberg Trial (Oxford University Press, Oxford, 2008) 683.
} 
wer sonst haette den Prozess fuehren sollen?" (Victor's justice, without doubt, occurred because nobody was allowed to ask for war crimes committed by the victorious powers; but who else should have carried out the lawsuit?). ${ }^{193}$

By answering the question whether the trial against the leading German jurists of the Nazi era was necessary from a moral point of view, I refer to the explanations in the respective chapter above. Nevertheless, I want to emphasise that, firstly, the trial brought to light for the first time details of the crimes committed in the name of justice in Nazi Germany and, secondly, it brought back civilised principles to the judicature on German territory after 12 years of judicial barbarity. A punishment without a trial would have only continued the brutality of the years of war and, therefore, would have been a bad solution.

Overall, I conclude this chapter with a statement of Lueders, which in my opinion is a good summary of what any critic of the Nuremberg Trials should always keep in mind: ${ }^{194}$

\footnotetext{
Independent of general international law, we Germans cannot raise any objections against these proceedings - from the legal standpoint - because with the unconditional surrender we have agreed to all measures of the Allies which are compatible with the commandments of humanity and that part of the principles of international law which is indispensable as a moral minimum.
}

\footnotetext{
${ }^{193}$ Golo Mann Deutsche Geschichte des 19. und 20. Jahrhunderts (Fischer Verlag, Frankfurt/Main, 1966) 972.

${ }^{194}$ Lueders, above n 127, 134.
} 


\section{INVOLVED PARTIES}

The laws, codes, internal directives, political plans, preparation, proceeding and outcome of a trial, in the end, always depend on the personalities of the involved people. The personal experiences, emotional connections and individual backgrounds of the parties involved are important factors in a lawsuit.

The major participants in the Justice Trial were the four Tribunal members, the members of the prosecution counsel and the 15 defendants together with their lawyers. ${ }^{195}$ When asking whether victor's justice occurred in the Justice Trial, it is especially important to have a look at these people and their individual backgrounds. The appointment of certain judges, the professional background of the prosecutors and the selection of the defendants poses the question: why these people and not others?

Morally, the trial, within the framework of all subsequent Nuremberg proceedings, was a trial not only of individuals from the German legal profession but of the whole German system of law under the Nazi Government with tens of thousands of participants. The reasons for the selection of the specific defendants as representatives of the Nazi judiciary, and the individual qualifications of the judges and prosecutors and their personal relationship to US post-war politics provide the information, which makes it possible to evaluate the trial on a more personal basis.

However, in the end, it will be concluded that a charge of victor's justice on these issues cannot be made for several reasons; most importantly, the exemplary impartiality of the Tribunal members and the thorough and non-arbitrary selection of the defendants by the prosecution.

195 Justice Case, above n 9, 13-14. 


\section{A The Tribunal}

Based on Control Council Law No. 10, the US Military Government for Germany enacted Ordinance No. 7 on 18 October 1946 to establish rules for the creation and procedure of military tribunals within the American zone of occupation in Germany. ${ }^{196}$ Article II section (b) of the Ordinance provided: "Each such tribunal shall consist of three or more members to be designated by the Military Governor. One alternate member may be designated to any tribunal if deemed advisable by the Military Governor. ...197

Accordingly, between 25 October 1946 and 24 December 1947 the Military Governor appointed 32 judges for the 12 tribunals of the subsequent Nuremberg proceedings. ${ }^{198}$ For the Justice Trial, Military Tribunal III was created by General Order No. 11 on 14 February 1947, which designated four judges as members of the Tribunal, namely Carrington T Marshall as Presiding Judge, James T Brand and Mallory B Blair as Judges, and Justin W Harding as Alternate Judge. ${ }^{199}$ For reasons of illness, Presiding Judge Marshall was relieved on 19 June 1947, and Brand was appointed Presiding Judge of the Tribunal from then on. ${ }^{200}$ Harding was promoted to be a regular judge on the same day. ${ }^{201}$

\footnotetext{
${ }^{196}$ See generally Military Ordinance No. 7 1946, above n 68.

${ }^{197}$ Ibid, art II s (b).

198 Taylor Final Report, above n 169, 35-36; See also Friedman, above n 2, 78.

199 Justice Case, above n 9, 7.

${ }^{200}$ Ibid, 8, 955.

201 Ibid.
} 


\section{$1 \quad$ The judges and their qualifications}

Article II section (b) of Ordinance No. 7 stated further that ${ }^{202}$ all members and alternates shall be lawyers who have been admitted to practice, for at least five years, in the highest courts of one of the United States or its territories or of the District of Columbia, or who have been admitted to practice in the United States Supreme Court.

This statute was based on the idea that military courts martial normally do not render opinions, ${ }^{203}$ and therefore, "judgments by professional, civilian judges would command more prestige both within Germany and abroad, in the legal profession and with the general public alike."204 The recruitment and selection of judges for the subsequent Nuremberg Trials was executed by the US War Department and the Office of the US Military Government for Germany (OMGUS). ${ }^{205}$ In the end, as stated above, 32 judges were appointed for the 12 trials.

Yet, the selection process was difficult and not without criticism. Contrary to Article II of Ordinance No. 7, US Supreme Court Chief Justice Harlan F Stone had prohibited Supreme Court justices from serving on any subsequent war crimes tribunal, after the first Nuremberg Trial was finished. ${ }^{206}$ The reason was that the Chief Prosecutor for the United States in the first trial, Robert H Jackson, was a Supreme Court Justice himself and, during his absence in Europe, the court often found itself deadlocked on major decisions. ${ }^{207}$ Stone wanted to avoid this happening again. ${ }^{208}$

To make it worse, Stone's successor as Chief Justice, Fred Vinson, extended the ban on federal judges as well. ${ }^{209}$ Hence, only state judges were

\footnotetext{
${ }^{202}$ Military Ordinance No. 7 1946, above n 68, art II s (b).

203 Taylor Final Report, above n 169, 28-29.

204 Ibid, 29.

${ }^{205}$ Ibid, 34-35.

${ }^{206}$ Friedman, above n 2, 78 .

${ }^{207}$ Ibid.

208 Ibid.

${ }^{209}$ Taylor Final Report, above n 169, 35; See also Friedman, above n 2, 78.
} 
left to ask. ${ }^{210}$ In the end, 25 of the 32 appointed judges were state court judges, of whom 14 had served on the highest court of a State and the others in State intermediate appellate or trial courts. ${ }^{211}$ The other seven judges included prominent practicing attorneys and a law school dean. ${ }^{212}$

Although a major concern about this selection was that none of these judges had extensive experience in international law or military laws, it was widely seen as an advantage that they had the status of Washington outsiders, a projection of homespun wisdom and impartiality. ${ }^{213}$ However, in some cases the character of the judges was criticised by prominent US lawyers like Abraham Pomerantz, ${ }^{214}$ and the Chief Prosecutor for the subsequent trials, Telford Taylor, told Robert H Jackson in a memorandum in 1946, after he was sent to a mission to the United States to recruit jurists for the prosecution teams in the subsequent trials: $:^{215}$

\footnotetext{
With few exceptions, the lawyers recruited have been poor. I do not refer to Pomerantz and Robbins. ... Most of the rest, however, are utterly vacuous political hacks. They are of no earthly use to us and if they aren't very unhappy already they are going to be very shortly. ... it is quite bad enough to have such persons visited upon us as lawyers, but it would be fatal in the case of the judges. I think that no judge should be sent over here without the personal approval of yourself or Judge Patterson $\left[{ }^{216}\right]$.
}

The four selected judges for Tribunal III in the Justice Case were all state court judges. Marshall was the former Chief Justice of the Supreme Court of Ohio, Brand was a Justice of the Supreme Court of Oregon, Blair was an Associate Justice of the Court of Civil Appeals of Texas and Harding was a former Assistant Attorney General of the State of Ohio and a District Judge in Alaska. ${ }^{217}$

\footnotetext{
${ }^{210}$ Friedman, above n 2, 78.

211 Taylor Final Report, above n 169, 35.

212 Ibid.

${ }^{213}$ Friedman, above n 2, 78

214 Ibid.

${ }^{215}$ Ibid, 77-78.

${ }^{216}$ Robert P Patterson was the United States Secretary of War under President Truman from 1945 to 1947. "Robert P. Patterson (1945-1947): Secretary of War" www.millercenter.org (last accessed 17 March 2010).

${ }^{217}$ Justice Case, above n 9, 13.
} 
Hence, it was not the elite of American jurists which sat in Nuremberg to judge over their German colleagues, but very experienced and highly regarded professional judges and prosecutors from civil courts in the American provinces. ${ }^{218}$

\section{Independence of the judges from US post-war politics}

After the selection of the judges many law experts became nervous about the neutrality of the judges. This was a legitimate concern. Firstly, the judges of Tribunal III were all from the United States; it was not only their home country, but also they necessarily had strong professional ties to the ideals of US law and politics. Secondly, they were no experts in international law; a possibly weak knowledge of the rules and customs of international law may have made them more susceptible to the views of the US Government in post-war Germany.

Yet, the ambitions of the US Government for post-war Germany were not necessarily bad. Certainly, a major purpose of the war crimes programme was the punishment of the Nazi perpetrators, but it was also intended to use the trials as an integral part of a policy to reorient the Germans by demonstrating to the German public the evils of totalitarianism and the virtues of democracy. ${ }^{219}$

Furthermore, it was hoped that the trials would result in a future code of conduct for governments and armies. ${ }^{220}$ Thus, it is a matter of fact that the punishment of the defendants was not the only reason for the trials, and the danger of non-impartiality of the judges in favour of the suggestions of the prosecution was therefore limited.

\footnotetext{
${ }^{218}$ Baestlein, above n 12, 17.

${ }^{219}$ Buscher, above n 72, 2.

${ }^{220}$ Ibid.
} 
However, one certain fact makes very clear that the judges of Tribunal III were and acted independently from governmental opinions and influences:

The indictment in the Justice Case, filed by the prosecution on 4 January 1947, contained 34 charges and was based on a comprehensive analysis of German judicial material, which had been brought together in so called Document Centres of the US Army in Germany since the end of the war. $^{221}$ The charges were summarized into four counts: (1) conspiracy to commit war crimes and crimes against humanity; (2) war crimes; (3) crimes against humanity; and (4) membership of certain defendants in criminal organisations. $^{222}$

By order from 11 July 1947, Tribunal III basically dropped count one, after the defendants had challenged it. ${ }^{223}$ It stated: ${ }^{224}$

It is the ruling of this Tribunal that neither the Charter of the International Military Tribunal nor Control Council Law No. 10 has defined conspiracy to commit a war crime or crime against humanity as a separate substantive crime; therefore, this Tribunal has no jurisdiction to try any defendant upon a charge of conspiracy considered as a separate substantive offense.

By looking at the importance this count had in the view of the US officials who developed the US war crimes trial programme including the legislation, it becomes clear that only truly independent judges would have made such a decision.

With reference to the trial before the International Military Tribunal, the Canadian historian Michael $\mathrm{R}$ Marrus stated that the charge of conspiracy "was an American product from first to last"225. Against strong objections of the French and Soviets, the US representatives at the London

\footnotetext{
${ }^{221}$ Baestlein, above n 12, 17; Justice Case, above n 9, 17-26.

${ }^{222}$ Justice Case, above n 9, 8, 955.

${ }^{223}$ Ibid, 956; See generally United Nations War Crimes Commission Law Reports of Trials of War Criminals: Trial of Josef Altstoetter and others (Case No 35) (Vol VI, His Majesty’s Stationery Office, London, 1948) 104-110.

${ }^{224}$ Justice Case, above n 9, 956.

${ }^{225}$ Michael R Marrus “The Nuremberg Trial: Fifty Years After” (1997) 66 Am Scholar $563,567$.
} 
Conference 1945 introduced the concept of conspiracy in the London Agreement and its annexed Charter. ${ }^{226}$

The whole conspiracy idea was based on the thoughts of Henry L Stimson and one of his assistants, a young New York lawyer named Murray Bernays, and it was fully adopted by Jackson and Taylor who were deeply convinced by the scheme. ${ }^{227}$ Conspiracy was the term the US jurists wanted to come up trumps with at Nuremberg. ${ }^{228}$ It was imagined not only as the crucial point of the American indictment before the International Military Tribunal, but also as an essential point of the indictments within the subsequent trials. ${ }^{229}$

Therefore, it was no surprise within the trial before the International Tribunal that the American prosecution took responsibility for count one (conspiracy), while the British prosecuted count two (crimes against peace) and the French and Soviets jointly prosecuted count three (war crimes) and count four (crimes against humanity). ${ }^{230}$

However, it remains that Tribunal III rejected the whole concept of conspiracy, which could have been seen not only as an insult to the prosecution but also to the Tribunal members' own superior, the head of the US War Department, Stimson.

\section{Conclusion}

There is no doubt that by present standards the judges of Tribunal III lacked the background, which would qualify them for an international war

\footnotetext{
${ }^{226}$ Beigbeder, above $\mathrm{n} 20,41$; See also Bradley F Smith Reaching Judgment at Nuremberg (Basic Books, New York, 1977) 51.

227 Thomas Darnstaedt "Das Weltgericht" (16 October 2006) 42 Der Spiegel Hamburg (Germany) 66 www.spiegel.de (last accessed 17 March 2010).

${ }^{228}$ Ibid.

${ }^{229}$ Gabi Mueller-Ballin Die Nuernbeger Prozesse 1945-1949 (BZ-Materialien Band 1, Nuernberg, 1995) 29, 32-33.

${ }^{230}$ Jackson Nyamuya Maogoto War Crimes and Realpolitik: International Justice from World War I to the $21^{\text {st }}$ Century (Lynne Rienner Publishers, Boulder, 2004) 98-99.
} 
crimes trial. However, it has to be considered that they were the most qualified US judges available at the time.

Regardless of whether judges from neutral countries would have been more suitable candidates, the members of Tribunal III acted with high diligence and impressive impartiality. According to Baestlein, the judges in the Justice Trial had not heard much about the circumstances in Germany during the war, and were confronted almost completely unprepared with the onset of barbarity in Germany's modern era between 1933 and 1945; ${ }^{231}$ before their eyes it opened up how a "Volk der Dichter und Denker" (a nation of poets and philosophers) left the circle of civilised nations and immediately turned into a "Volk der Richter und Henker" (a nation of judges and hangmen). ${ }^{232}$

Although understandably shocked by this, the judgment and sentences of Tribunal III indicate an instinctive feeling and great care in evaluating the situation of German law and lawyers during the Nazi regime. ${ }^{233}$ Considering the given facts the defendants were tried for, the Tribunal, in the end, showed an exemplary impartiality. Therefore, I conclude with the words of Lueders, written in regard to the trial before the International Military Tribunal, but which, in my opinion, are equally valid for the Justice Trial: ${ }^{234}$

At the beginning many may have thought the Nuremberg judges were not fit for the task because as citizens of the victorious states they would not face the defendants free from hatred, passion, and national prejudice. Many may therefore have thought of a trial by German judges as more just. But today, when the judgment of Nuremberg and the reaction to it among the German population is known, only malevolent persons and hardened National Socialists can doubt the real objectivity of these judges.

\footnotetext{
${ }^{231}$ Baestlein, above n 12, 20.

${ }^{232}$ Ibid.

${ }^{233}$ See Part V Judgment of the Tribunal.

${ }^{234}$ Lueders, above n 127, 135.
} 


\section{B The Prosecution}

On 2 May 1945, the Joint Chiefs of Staff of the US Government created the Office of the Chief of Counsel for the Prosecution of Axis Criminality (OCCPAC). ${ }^{235}$ Supreme Court Justice Robert H Jackson was appointed Chief of Counsel and, accordingly, became the Chief Prosecutor for the United States in the major trial against the Nazi leaders before the International Military Tribunal. ${ }^{236}$

In November 1945, the Subsequent Proceeding Division within OCCPAC (SPD-OCCPAC) was established to prepare the American zone trials under Control Council Law No. 10. ${ }^{237}$ Colonel Telford Taylor was named head of the division. ${ }^{238}$ Later on, in March 1946, Taylor was also named the successor of Jackson and received the military rank of Brigadier General, ${ }^{239}$ but it was not until October 1946, after the International Military Tribunal had come to a close, when Taylor replaced Jackson. ${ }^{240}$

During Jackson's term, Taylor was subordinate of and accountable to Jackson, who himself reported directly to US President Truman. ${ }^{241}$ Yet, after the major trial was finished and Jackson had resigned, this changed. ${ }^{242}$ On 24 October 1946, the OCCPAC was dissolved and succeeded by the Office of the Chief of Counsel for War Crimes (OCCWC), which was created as a division of the Office of the US Military Government for Germany (OMGUS). ${ }^{243}$ Taylor was appointed as the new Chief of Counsel and Chief Prosecutor for the United States by Military Governor General

\footnotetext{
235 Joseph Brunner "American Involvement in the Nuremberg War Crimes Trial Process" (Winter 2002) Mich J Hist I.

236 Ibid.

237 Ibid.

238 Ibid.

${ }^{239}$ Friedman, above n 2, 77.

${ }^{240}$ Buscher, above n 72, 31.

${ }^{241}$ Taylor Final Report, above n 169, 13.

242 Ibid.

243 Ibid.
} 
McNarney, ${ }^{244}$ and from now on, was no longer accountable to the President but to the Military Governor. ${ }^{245}$

1 The prosecutors and their qualifications

As mentioned before, Chief Prosecutor Taylor was not convinced about the quality of his staff for the subsequent trials. ${ }^{246}$ As well as being hard for the War Department to find adequate judges, it was hard for the OCCWC to find qualified prosecutors. ${ }^{247}$ It was even harder as the task of recruiting and selecting suitable lawyers for all 12 subsequent trials was on Taylor and his office alone, alongside with all the other executive and administrative tasks necessary to hold trials of such dimensions, including the selection of the defendants, interrogations of witnesses and suspects, handling of linguistic problems, cooperation with other governments, organisation of all physical facilities, technical and other equipment, staff recruitment and so forth. ${ }^{248}$

Consequently, in his Final Report to the Secretary of the Army on the Nuernberg War Crimes Trials under Control Council Law No. 10, he retrospectively complained about the huge amount of administrative responsibilities, which were imposed solely on the prosecution. ${ }^{249}$ His complaint was confirmed by the figures, which are truly impressive:

In total, 1,200 court sessions were held by the 12 tribunals, and the transcripts of these proceedings exceeded 330,000 pages, ${ }^{250}$ in July 1946, the staff of OCCWC numbered 113, by the end of the year 1,000 and at its

\footnotetext{
${ }^{244}$ Justice Case, above n 9, XXIII.

${ }^{245}$ Taylor Final Report, above n 169, 13.

${ }^{246}$ See Part III A 1 The judges and their qualifications.

${ }^{247}$ Friedman, above n 2, 77.

${ }^{248}$ Taylor Final Report, above n 169, VII, 14-21.

${ }^{249}$ In his conclusion, Taylor suggested that it would have been much better if "at the very outset a single organization for the purpose of planning and carrying out the war crimes trials" had been established, and the field of administrative responsibility was not be solely placed on the prosecution. Ibid, 105-106.

${ }^{250}$ Justice Case, above n 9, III.
} 
peak in October 19471,$774 ;^{251}$ an enormous amount of pages was translated by OCCWC throughout the trials, 133,762 pages alone between September 1947 and September $1948 ;{ }^{252}$ an average of 175,000 copies were made per month; ${ }^{253}$ the prosecution offered 605 different document books with a total amount of over 6 million pages, including 46,000 copies of these books; ${ }^{254}$ and approximately 10,000 interrogations were conducted by OCCWC between October 1946 and October 1948. ${ }^{255}$

By looking at these figures, it becomes clear what Taylor meant when he stated: "The task which the Division faced was enormous and complex, and the recruitment problem was correspondingly difficult." The recruitment of lawyers was only one part of the duties of OCCWC, and perhaps, explains the overall lack of quality of the selected persons.

However, in the Justice Case, Taylor had formed at an early stage a prosecution team mainly from personnel of the Ministries Division within OCCWC ${ }^{257}$ and placed it under the direction of Charles M LaFollette, who was appointed Deputy Chief Counsel. ${ }^{258}$ Besides Taylor as the Chief of Counsel, LaFollette became the face of the prosecution in the Justice Trial. They were assisted by the Associate Counsels Robert D King and Alfred M Wooleyhan, and Assistant Counsel Sadie B Arbuthnot. ${ }^{259}$

Due to limited space, a broad look will be undertaken only in regard to Taylor's and LaFollette's biographies. Nevertheless, it is well-recognised that the work and success of the prosecution counsel depended on the whole team and not on these two persons only.

\footnotetext{
${ }^{251}$ Taylor Final Report, above n 169, 14, 43-44.

252 Ibid, 45.

253 Ibid.

${ }^{254}$ Ibid.

255 Ibid, 61.

${ }^{256}$ Ibid, 14

${ }^{257}$ To prepare the trials and indictments, the OCCWC at the outset was divided in six divisions: the Military, Ministries, SS, and Economics Divisons worked on the cases which lay within the fields of their respective titles; additionally, two special divisions were established to prepare the I.G. Farben case and the Flick case for trial. Ibid, 39.

${ }^{258}$ Ibid, 40; Justice Case, above n 9, 14.

${ }^{259}$ Justice Case, above n 9, 14.
} 
(a) Taylor

Telford Taylor was born in 1908 and died in $1998 .{ }^{260}$ He was a superior student and graduated from Harvard Law School in $1932 .{ }^{261}$ Due to his brilliance, he soon became a protégé of the prominent professor and Supreme Court Justice Felix Frankfurter. ${ }^{262}$ Before Taylor joined the Army in October 1942, he worked in various federal offices of the United States, including the Department of Justice, which gave him many appearances before the Supreme Court and put him in first contact with Robert $\mathrm{H}$ Jackson. $^{263}$

During the war, he worked for the US Army Intelligence Service in England, which helped him to gain expertise on Germany that he later used at the war crimes trials. ${ }^{264}$ In 1944, he was appointed Military Attaché in the US Embassy in London, and in 1946, he became an assistant of the Chief Prosecutor for the first Nuremberg Trial Jackson. ${ }^{265}$

Despite the increasing calls for vengeance after the revelations of Nazi atrocities mounted, Taylor, together with Jackson, remained committed to conducting fair proceedings within a defined legal framework. ${ }^{266}$ Throughout his life, Taylor was a strong advocate of the new international law, which was created with his help in the London Agreement and its annexed Charter, even when it was uncomfortable for the Allies itself; for example, he condemned the lifelong imprisonment of Rudolf $\mathrm{Hess}^{267}$ in

260 "Telford Taylor" The Scribner Encyclopedia of American Lives, Volume 5: 19997-1999 http://galenet.galegroup.com.helicon.vuw.ac.nz/servlet/BioRC (last accessed 17 March 2010).

261 Ibid.

262 Ibid.

263 Ibid.

264 Ibid.

265 Ibid.

${ }^{266}$ Robert Cherny "Telford Taylor” http://c250.columbia.edu/c250_celebrates/remarkable columbians/telford_taylor.html (last accessed 17 March 2010).

${ }^{267}$ Rudolf Hess was a high ranked Nazi, who was sentenced to life imprisonment in the trial against the major war criminals before the International Military Tribunal; he was imprisoned at the Spandau Prison in Berlin for more than 40 years, being the only inmate 
Berlin's Spandau Prison by saying that "such long-continued incarceration, especially in a huge prison where he was the sole inmate, was a crime against humanity."268

In the decades after the Nuremberg Trials, Taylor became famous and highly considered for his criticism of US politics and actions in Vietnam, Nicaragua and Bosnia. ${ }^{269} \mathrm{He}$ also was among the first opponents of Senator McCarthy's Anti-Communism programme in the United States in the 1950 s. $^{270}$

Taylor left the Army in 1949, highly decorated by the United States and several foreign governments, and returned to New York to practice law. ${ }^{271}$ Until his death, he taught at prominent law schools like Columbia, Harvard, Yale and Cardozo; ${ }^{272}$ and he was the author of several books, including The Anatomy of the Nuremberg Trials (1992) and the award winning Munich: The Price of Peace (1979). ${ }^{273}$

(b) LaFollette

Charles M LaFollette was born in 1898 and died in $1974 .{ }^{274} \mathrm{He}$ served in the US Army during World War I and, afterwards, studied law at Vanderbilt University. ${ }^{275}$ In 1925, he was admitted to the bar and commenced practice in Evansville/Indiana. ${ }^{276}$

for most of the time, and committed suicide there in 1987 at the age of 93. Richard Severo "Telford Taylor, who prosecuted Nazis at Nuremberg War Crimes Trials, is dead at 90" (24 May 1998) The New York Times New York (US) www.nytimes.com (last accessed 17 March 2010).

268 Ibid.

${ }^{269}$ Cherny, above n 266.

${ }^{270}$ Severo, above n 267.

271 “Telford Taylor", above n 260.

272 Cherny, above n 266.

273 W Hays Parks “Telford Taylor, 1908-1998” www.icrc.org (last accessed 17 March 2010)

274 “La Follette, Charles Marion, (1898-1974)" www.bioguide.congress.gov (last accessed 17 March 2010)

275 Ibid.

276 Ibid. 
LaFollette was a prominent lawyer as well as a politician, and he was a member of the Indiana State House of Representatives from 1927 to 1929. ${ }^{277}$ In 1943, he was elected as a member of the Republican Party for the US House of Representatives. ${ }^{278}$ He served two terms until 3 January 1947, but was not a candidate for re-election, due to his assignment as Deputy Chief of Counsel in Nuremberg. ${ }^{279}$

Like Taylor, LaFollette was strongly convinced of the necessity of a fair trial in respect to the historic significance of the Nuremberg war crimes trials and, therefore, became a strong advocate against the accusation of victor's justice. In 1948, he stated: ${ }^{280}$

I believe that not only a real contribution was made to the body of international law by the trial of this case but also that valuable lessons can be learned by the legal profession and by laymen all over the world from the evidence produced there. If a person distrusts the fairness of the procedure he undervaluates the important principles of international law announced and applied in this case.

After the Justice Trial was finished, LaFollette became the Director of the US Office of Military Government for Wuerttemberg-Baden in Southwest Germany. ${ }^{281} \mathrm{He}$ held this position from December 1947 to January 1949, before returning to the United States where he went back in his old life as a lawyer and politician. ${ }^{282}$

\section{Conclusion}

Between the creation of OCCWC on 24 October 1946 and its deactivation on 20 June $1949,{ }^{283}$ its staff accomplished an outstanding

\footnotetext{
277 Ibid.

278 Ibid.

279 Ibid.

${ }^{280}$ Charles M LaFollette "Justice Case at Nuremberg, Part I" (1948) 138 Information Bulletin, Magazine of US Military Government in Germany 9, 9.

281 "La Follette, Charles Marion, (1898-1974)", above n 274.

282 Ibid.

${ }^{283}$ Taylor Final Report, above n 169, VII.
} 
performance in both quantity and quality of the work of the prosecution counsel in all 12 subsequent trials. The task, the division was confronted with, could have just as well been a lifetime process, but it was all managed and finished in less than three years.

All US officials agreed that the trials should be completed quickly after the war, but most of them had underestimated the size and difficulty of the programme. ${ }^{284}$ As a result, there was not enough time and resources to recruit the best of the best for the prosecution teams. Additionally, military rules like the spousal ban made it extra hard to find willing lawyers, until it was overturned. ${ }^{285}$ However, the evidence given by German documents was so overwhelming that it was a much easier job to prosecute than to judge. ${ }^{286}$

In the Justice Trial, the leading figures for the prosecution were Charles M LaFollette and Telford Taylor. Whether or not LaFollette had a good legal knowledge of international law and the functioning of the German law system, he was limited to the principles and rules set by the London Agreement, its annexed Charter, Control Council Law No. 10 and US Ordinance No. 7 anyhow.

Also, it is likely that the knowledge about the German judiciary and the role of the German jurists in general was poor outside Germany at the time. By preparing the indictment, Taylor, LaFollette and their team had to study the German legal documents, which were captured by the Allied forces all over Europe during and after the war, intensively. As a result, they automatically became experts of the German law system under the Nazis.

Additionally, Taylor was regarded as one of the best US jurists of his generation, and he proved this by excellent performances in court during the subsequent trials. ${ }^{287}$ As Herbert Wechsler, a prominent legal scholar himself who had worked together with Taylor in Nuremberg, put it: "If I was asked

\footnotetext{
${ }^{284}$ Ibid, 76, 104.

${ }^{285}$ Taylor had enormous problems to find adequate lawyers for his team because of the Army's general spousal ban. He reported this to Jackson, who filed an objection with the result that the spousal ban was removed. Friedman, above n 2, 77.

${ }^{286}$ Taylor Final Report, above n 169, 50.

${ }^{287}$ See for example his opening statement for the prosecution in the Justice Trial. Justice Case, above n 9, 31-108.
} 
to name the person of my generation whom I most admired, I would promptly answer Telford Taylor. ... wise counselor, persuasive advocate, careful scholar, all the qualities that signify distinction ... were his degree."288

\section{The Defendants}

From the very beginning, it was planned by the US authorities that the defendants in the Nuremberg Trials should represent all major segments of the Third Reich, including government officials, SS, police and Party officials, military leaders, bankers and industrialists. ${ }^{289}$

When the organisation of the trials began, it was soon realised that only a few persons out of the hundreds of thousands of potential candidates could possibly be tried. ${ }^{290}$ Including those individuals which were members of a Nazi organisation declared criminal by the International Military Tribunal, the total number was no less than an estimated two million persons in all of Germany and approximately 500,000 in the US occupation zone. $^{291}$

There was no way for OCCWC to deal with such an amount of people and, therefore, the vast majority of these cases were excluded from the Nuremberg proceedings and handled under the so called denazification programme. $^{292}$ However, there were still several thousands of persons left. $^{293}$

\footnotetext{
${ }^{288}$ Cherny, above $\mathrm{n} 266$.

${ }^{289}$ Taylor Final Report, above n 169, 74.

${ }^{290}$ Maugham, above n 49, 20.

${ }^{291}$ Taylor Final Report, above n 169, 16.

${ }^{292}$ Ibid; Besides the Nuremberg Trials and other trials of the Allies carried out in their respective occupation zones, the denazification programme was the joint effort of the Allies to remove active members of the former National Socialist Party from public office and influential positions in Germany after World War II. It was based on the Law for Liberation from National Socialism and Militarism (commonly known as Denazification Law), which was enacted in 1946 by the Allied Control Council for Germany. Millions of individuals (in the US zone of occupation more than 13 million persons alone) were screened for their role in Nazi Germany and categorized in (1) major offenders, (2) offenders, (3) lesser offenders,
} 
The selection of the defendants was the exclusive responsibility of the Chief of Counsel Telford Taylor, ${ }^{294}$ who had realised early that only a maximum of a few hundred persons could be tried, but these ${ }^{295}$

should be those highly placed individuals who bore the greatest responsibility for formulating and ordering the execution of the criminal policies which directly led to and instigated the aggressive wars and mass atrocities launched and committed under the authority of the Third Reich.

With these self-made high expectations, Taylor started the selection process by firstly making a list of several thousand suspects, and then reducing this list on and on until he held 570 persons in confinement. ${ }^{296}$ In the end, with the assistance of his large staff, 185 individuals were finally selected for indictment at the 12 subsequent Nuremberg Trials. ${ }^{297}$

Concerning the Justice Case, 16 leading Nazi jurists were selected, but only 14 were actually tried. ${ }^{298}$ Carl Westphal committed suicide in his cell in Nuremberg, and a mistrial was declared in Karl Engert's case because of illness. ${ }^{299}$

(4) followers, and (5) persons exonerated. In the end, the programme failed to a large extent because political changes, especially the upcoming Cold War, caused the Allies to transfer the programme into the hands of German post-war authorities and many former Nazis were rehabilitated although undoubtedly involved in Nazi crimes. Jozeph Michmann and Michael Berenbaum "Denazification" www.jewishvirtuallibrary.org (last accessed 17 March 2010); See also Whitney R Harris, above n 18, 441-542.

${ }^{293}$ Taylor stated that " 2,000 or even 20,000 could have been convicted ...". Taylor Final Report, above n 169, 74 .

${ }^{294}$ Ibid, 73, 85.

295 Ibid, 54

${ }^{296}$ Maugham, above n 49, 20.

${ }^{297}$ From the 185 defendants only 177 were actually tried, because eight persons committed either suicide or were severed from the proceedings by reason of illness. Taylor Final Report, above n 169, 91.

${ }^{298}$ Justice Case, above n 9, 3; See also Roger Clark and Irina A Lediakh "Influence on the Development of International Law" in George Ginsburgs and Vladimir N Kudriavtsev (eds) The Nuremberg Trial and International Law (Martinus Nijhoff Publishers, Dordrecht, 1990) 266.

${ }^{299}$ Justice Case, above n 9, 3, 15-16. 


\section{$1 \quad$ Selection criteria}

As mentioned above, it was the intention of Taylor and his staff to bring to trial the leaders and key figures of Nazi Germany's judiciary. ${ }^{300}$ However, its highest leaders could no longer be prosecuted: Reich Minister of Justice Franz Guertner had died in 1941; his successor, Otto Georg Thierack, had committed suicide in a British internment camp in 1946; Erwin Bumke, President of the Reichsgericht, had also committed suicide as the US Army was entering the city of Leipzig in 1945; and the infamous President of the People's Court, Roland Freisler, had been killed in Berlin in an air raid in March $1945 .^{301}$

Hence, the principal defendant in the dock was Franz Schlegelberger, Acting Reich Minister of Justice from 29 January 1941 to 20 August 1942. ${ }^{302}$ The other defendants included several more highranking officials of the Reich Ministry of Justice, the Chief Prosecutor of the People's Court and several prosecutors and judges of both the People's Court and Special Courts. ${ }^{303}$

The defendants in the Justice Trial were selected for different reasons, but mainly because they were the highest-ranking available officials among the German jurists. Nevertheless, after the most prominent faces of the German judiciary had disappeared, the selection process was a difficult task for the prosecution.

\footnotetext{
${ }^{300}$ See Part III C The Defendants.

${ }^{301}$ Mueller, above n 120, 270.

${ }^{302}$ Taylor Final Report, above n 169, 169; Justice Case, above n 9, 16, 1082.

${ }^{303}$ Justice Case, above n 9, 3.
} 
(a) General aspects

In general, the prosecution had based its final selection of the individuals to be indicted in the 12 subsequent trials on four basic factors:

Firstly, the collection and analysis of written and oral evidence, and what the evidence showed concerning the activities of particular individuals. ${ }^{304}$ The existence of substantial evidence was an absolute necessity, because it was a firm policy of OCCWC not to indict anyone without such. ${ }^{305}$

Secondly, the use of deductive and inductive methods of investigation based on the knowledge of the prosecution staff members about the organisation and functioning of the law system in the Third Reich. ${ }^{306}$ The staff members were expected to familiarise themselves as rapidly as possible with it. ${ }^{307}$ Additionally, a special section within OCCWC was set up to compile a list of who's who of leading German politicians, civil servants, military men, business men and others. ${ }^{308}$

The third factor was the availability of individuals. ${ }^{309}$ Many war crime suspects were not located until a year or more after the end of the war, and some were under arrest but not available for trial or were held under arrest in other occupation zones and not available for the US authorities. ${ }^{310}$

Fourthly, the number of individuals to be tried depended on the overall policy and on administrative factors such as time, staff and money. ${ }^{311}$ For legal and policy reasons, the trials were planned to be completed without unnecessary delay, when the evidence was still fresh and

\footnotetext{
${ }^{304}$ Taylor Final Report, above n 169, 74.

${ }^{305}$ Ibid, 75 .

${ }^{306}$ Ibid.

${ }^{307}$ Ibid.

${ }^{308}$ Ibid.

${ }^{309}$ Ibid.

${ }^{310}$ Ibid, 75-76.

${ }^{311}$ Ibid, 76.
} 
the general public was still interested. ${ }^{312}$ Administrative issues were of a more practical nature but inevitable, for example, the size of the defendants' docks in the courtrooms. ${ }^{313}$

Altogether, these criteria helped the prosecution to separate the wheat from the chaff. Nevertheless, tribute had to be paid in regard to the limited facilities available at the location where the trials were held, the Nuremberg Palace of Justice. ${ }^{314}$ Accordingly, Taylor stated self-critically in $1949:^{315}$

It should be made perfectly clear that the individuals indicted under Law No. 10 were a small minority of those who, on the basis of the available evidence, appeared and probably could be proved to be guilty of criminal conduct. ... The responsibility for the selection of defendants in the Nuernberg trials under Law No. 10 was mine alone, and the blame for any mistakes that were made is equally mine.

(b) Individual aspects

The selection of the specific defendants in the Justice Trial was based on a mixture of availability of the persons and severity of their offences. As mentioned before, the highest leaders of the German judiciary

\footnotetext{
${ }^{312}$ Ibid.

${ }^{313}$ Six courtrooms in total were available for the subsequent trials. Two could accommodate up to 24 defendants, whether the others had capacity for a maximum of 15 defendants. The Justice Case was held in one of the smaller courtrooms, and it was the trial with the largest amount of defendants in these smaller courtrooms. Ibid, 77.

314 The Palace of Justice in Nuremberg was chosen as the site for the trials, because it was spacious and as one of very few buildings throughout Germany largely undamaged, and a large prison was part of the complex. Also, there was a symbolic value as Nuremberg had been the city of the Nazi Party rallies, and the place where the German Parliament had met in its one session outside Berlin during the Third Reich in 1935, where it enthusiastically approved the measures against the German Jews, commonly known as the Nuremberg Laws. Carmelo Lisciotto "The $1^{\text {st }}$ Nuremberg Trial" www.holocaustresearchproject.org (last accessed 17 March 2010); Gerhard L Weinberg "The Setting and the Significance of the Nuremberg Trials: A Historian's Perspective" in Nathan Stoltzfus and Henry Friedlander (eds) Nazi Crimes and the Law (Cambridge University Press, New York, 2008) 35.

${ }^{315}$ Taylor Final Report, above n 169, 74, 85.
} 
could no longer be tried, ${ }^{316}$ and therefore, the next level of jurist leaders came into focus.

Primarily, these were eight high ranked officials of the Reich Ministry of Justice and members of both the People's Court and Special Courts. ${ }^{317}$ The prosecution put its focus especially on these institutions because the Ministry was the administrative supreme authority within the German law system, and the People's Court as well as the Special Courts had been a special creation of the Nazis with a focus on so called political offences. $^{318}$

(i) Officials of the Reich Ministry of Justice

The Ministry of Justice was hierarchically structured, and the eight selected defendants for the Justice Trial all held high positions within the institution. $^{319}$

Josef Altstoetter was Chief of the Civil Law and Procedure Division in the Reich Ministry of Justice; he also was a member of the SS. ${ }^{320}$

Wilhelm von Ammon was the Ministerial Counsellor of the Criminal Legislation and Administration Division in the Reich Ministry of Justice; he also was the coordinator of proceedings against foreigners for offences against Reich occupational forces abroad. ${ }^{321}$

Guenther Joel was Legal Adviser to the Reich Minister of Justice concerning criminal prosecutions; also, he was the Chief Public Prosecutor of Westphalia at Hamm and a member of the SS and SD. ${ }^{322}$

\footnotetext{
${ }^{316}$ See Part III C 1 Selection criteria.

${ }^{317}$ Klaus Kastner "Der Dolch des Moerders war unter der Robe des Juristen verborgen: Der Nuernberger Juristen-Prozess 1947” (1997) Juristische Arbeitsblaetter 699, 700.

${ }^{318}$ Mueller, above n 120, 51-52.

${ }^{319}$ Justice Case, above n 9, 212-217.

${ }^{320}$ Ibid, 15.

${ }^{321}$ Ibid.

${ }^{322}$ Ibid, $15-16$
} 
Herbert Klemm was State Secretary in the Reich Ministry of Justice; he also was the Director of the Legal Education and Training Division in the Ministry, Deputy Director of the National Socialist Lawyers League and a member of the SA. ${ }^{323}$

Wolfgang Mettgenberg held the position of Representative of the Chief of the Criminal Legislation and Administration Division in the Reich Ministry of Justice; in particular, he supervised criminal offences against German occupational forces in occupied territories. ${ }^{324}$

Curt Rothenberger held the position of State Secretary in the Reich Ministry of Justice; additionally, he was Deputy President of the Academy of German Law and a Regional Leader of the National Socialist Lawyers League. $^{325}$

Franz Schlegelberger was a State Secretary in the Ministry of Justice, before becoming the Acting Reich Minister of Justice from 29 January 1941 to 20 August $1942 .{ }^{326}$

Carl Westphal was Ministerial Counsellor of the Criminal Legislation and Administration Division in the Reich Ministry of Justice; he was responsible for questions of criminal procedure and penal execution within the Reich; additionally, he was the Ministry coordinator for nullity pleas against adjudicated sentences. ${ }^{327}$

(ii) Members of the National Socialist People's Court

The Volksgerichtshof (People's Court) was established on 24 April 1934, and was created to further the aims of National Socialism. ${ }^{328}$

${ }^{323}$ Ibid, 16.

${ }^{324}$ Ibid.

${ }^{325}$ Ibid.

${ }^{326}$ Ibid.

${ }^{327}$ Ibid, 16-17.

${ }^{328}$ Mueller, above n 120, 140. 
Subdivided into a number of senates and departments, its tribunals consisted each of two judges and five officials of the Nazi Party. ${ }^{329}$

Contrary to the widespread opinion of the general public, the People's Court was not the superior court of Germany (that was the Supreme Court in Leipzig) but an elite court with virtually exclusive jurisdiction over cases of treason and high treason, espionage and undermining of national defence. ${ }^{330}$ The People's Court soon became infamous for its severe sentences; between 1937 and 1944, 14,319 defendants were indicted, of whom 5,191 received the death penalty. ${ }^{331}$

Six of the defendants in the Justice Trial had been members of the People's Court and worked there either as judges or public prosecutors.

Paul Barnickel was a Senior Public Prosecutor of the People's Court; at the same time he was a member of the SA. ${ }^{332}$

Karl Engert was Vice President of the People's Court; additionally, he held the position of Chief of the Penal Administration Division and of the secret Prison Inmate Transfer Division in the Reich Ministry of Justice; he also was a member of the SS and the NSDAP Leadership Corps. ${ }^{333}$

Ernst Lautz was the Chief Public Prosecutor of the People's Court. ${ }^{334}$

Guenther Nebelung was Chief Justice of the Fourth Senate of the People's Court; he also was a member of the SA and of the NSDAP Leadership Corps. ${ }^{335}$

Hans Petersen was a Lay Judge of both the First Senate and the Special Senate of the People's Court; he was a member of the SA. ${ }^{336}$

\footnotetext{
${ }^{329}$ Justice Case, above n 9, 1004.

${ }^{330}$ Hannsjoachim Wolfgang Koch In the Name of the Volk: Political Justice in Hitler's Germany (Tauris, London, 1989) 3, 128-130.

${ }^{331}$ Mueller, above n 120, 143.

332 Justice Case, above n 9, 15.

${ }^{333}$ Ibid.

${ }^{334}$ Ibid, 16.

335 Ibid.

336 Ibid.
} 
Oswald Rothaug was a Senior Public Prosecutor of the People's Court; before, he had been the former Chief Justice of the Special Court in Nuremberg; he also was a member of the NSDAP Leadership Corps at regional level. ${ }^{337}$

(iii) Members of National Socialist Special Courts

On 21 March 1933, soon after the Nazis had taken over the German Government, so called Sondergerichte (Special Courts) were erected within each of the 26 Court of Appeals districts in Germany. ${ }^{338}$ They soon became an effective tool against the political opposition, as the defendants had no right to appeal verdicts and the sentences took effect immediately. ${ }^{339}$ During the war, Special Courts were also erected in the occupied territories. ${ }^{340}$

The courts had jurisdiction over all crimes that threatened the National Socialist state and ideology, such as violations of all directives of the national government, incitement to such violations that caused public danger, high treason, arson, sabotage and aggravated insurrection. ${ }^{341}$ Like the People's Court, the Special Courts became infamous for their harsh sentences, including more than 15,000 death penalties. ${ }^{342}$ In fact, the Special Courts fulfilled the dream of the Nazi leaders "of a judicial system in which the harshest of sentences could be imposed after a minimum of formalities"343.

Three of the defendants in the Justice Trial had been members of Special Courts, including Oswald Rothaug who, by the end of the war, was

\footnotetext{
${ }^{337}$ Ibid.

${ }^{338}$ Mueller, above n 120, 153.

${ }^{339}$ Ibid, 153-154.

${ }^{340}$ Ibid, 159-160.

${ }^{341}$ Ibid, 51

342 Helmut Kramer "Richter vor Gericht: Die juristische Aufarbeitung der Sondergerichtsbarkeit" (2007) 15 Juristische Zeitgeschichte NRW 121, 122.

${ }^{343}$ Mueller, above n 120, 159.
} 
a Public Prosecutor at the People's Court. ${ }^{344}$ The remaining two defendants were Hermann Cuhorst and Rudolf Oeschey.

Hermann Cuhorst was Chief Justice of the Special Court in Stuttgart and Chief Justice of the First Criminal Senate of the District Court in Stuttgart; he also was a member of the Leadership Corps of the Nazi Party and a sponsoring member of the $\mathrm{SS} .^{345}$

Rudolf Oeschey was a Judge of the Special Court in Nuremberg and successor of the defendant Rothaug as Chief Justice of the same court; he was a member of the NSDAP Leadership Corps at regional level and an executive of the National Socialist Lawyers League. ${ }^{346}$

\section{Conclusion}

The selection of the defendants in the Justice Trial was done with great care and accuracy by the prosecution. Furthermore, the selection criteria were legitimate and comprehensible. However, it is interesting that no legal scholar or defence lawyer was indicted.

In the case of lawyers it is perhaps understandable, because they had, at least formally, the function of defending defendants against the accusations of the National Socialist State, but scholars had been an important factor of spreading the Nazi ideology and the decline of law during the Third Reich. ${ }^{347}$

Certainly the most prominent Nazi scholar was the so called state thinker of the Third Reich Carl Schmitt. As early as 1934 he stated: "The whole of German law today ... must be governed solely and exclusively by the spirit of National Socialism ... Every interpretation must be an

\footnotetext{
${ }^{344}$ See Part III C 1 (b) (ii) Members of the National Socialist People's Court.

${ }^{345}$ Justice Case, above n 9, 15.

${ }^{346}$ Ibid, 16.

${ }^{347}$ Mueller, above n 120, 68.
} 
interpretation according to National Socialism."348 Together with other leading National Socialist professors, for example Ernst Forsthoff, Ernst Rudolf Haber and Theodor Maunz, he was the originator of the new Nazi doctrines in the field of law. ${ }^{349}$

It is an embarrassing fact for post-war Germany that the majority of these professors retained their positions or returned to them in the 1950s, Maunz even became a co-editor and co-author of the leading commentary to the new German Basic Law of $1949,{ }^{350}$ but in regard to the Nuremberg war crimes trials they could hardly be accused.

Although they helped to build the legal basis for the Nazi state, they did not participate directly in the Nazi legislation or the execution of these laws. Therefore, in the end, it makes more sense that Ministry officials and judges were indicted rather than those who were responsible only indirectly.

Furthermore, the selection of the individual defendants cannot be seen as arbitrary. No doubt that there were many other judges or officials in the German judiciary who could also have been selected for the trial, especially among the Special Court Judges, but it could never be an acceptable argument against the selection of the 16 defendants. The limited resources simply made it impossible for the US Military Government to try all potential war criminals at Nuremberg.

Also, it cannot be said that the selection process spared highly respected persons or prominent individuals. Schlegelberger, for example, was held in high esteem by the public. He had an excellent reputation, and many people labelled him as the last decent jurist under Hitler. ${ }^{351}$ I agree with Taylor who stated: ${ }^{352}$

The trials under Law No. 10 ... explored the record and judged the conduct of a large number of men, who were not 'professional Nazis' but who occupied key positions in the Third Reich, such as career diplomats,

\footnotetext{
348 Carl Schmitt "Nationalsozialismus und Rechtsstaat" (1934) 63 Juristische Wochenschrift 713 cited in Ibid, 70.

${ }^{349}$ Ibid, 42.

${ }^{350}$ Ibid, 236.

${ }^{351}$ Baestlein, above n 12, 13.

${ }^{352}$ Taylor Final Report, above n 169, 109.
} 
doctors, lawyers and judges, businessmen, and military leaders. Whatever mistakes were made at Nuernberg, and no doubt there were many, I do not think it can ever be seriously charged that wealth, prestige, or the 'garments of respectability' served to protect from indictment any individual against whom substantial evidence appeared to exist, or that any group or category was singled out for either favourable or severe treatment.

Overall, it is obvious that the 185 indictments in the subsequent Nuremberg Trials constituted only a minute fraction of the hundreds of thousands of suspected Nazi criminals who remained at large, ${ }^{353}$ but nobody can seriously complain that those, who were finally indicted in the Justice Case, did not belong there.

${ }^{353}$ Friedman, above n 2, 95. 


\section{TRIAL-PROCEEDINGS}

After the indictment had been filed on 4 January 1947, and the defendants had been arraigned on 17 February 1947, the Justice Trial officially opened on 5 March 1947 with the opening statement of the prosecution. ${ }^{354}$ The trial needed 129 court sessions, lasted 11 month and the English transcript of the proceedings comprised 10,964 mimeographed pages. ${ }^{355}$ The final statements of the defendants were heard on 18 October 1947, and the judgment and sentences were delivered on 3 and 4 December 1947.356

In this chapter, firstly, the charges against the defendants and their compatibility with existing international law and principles at the time will be analysed. In terms of victor's justice, it will be asked whether the charges were only a creation of the victorious Allies to hide the exercise of vengeance behind a smokescreen of legality or were the proper expression of international criminal law.

A conclusion will be drawn stating that the charges did change but not violate international law and, therefore, justified the trial. However, the fact that they were applied only on the defeated Germans has to be evaluated as an example of victor's justice.

Secondly, the chapter will look at certain aspects of the trialproceedings and asks the question whether the defendants were treated fairly. It will be concluded that the defendants received a fair trial and the Americans, herewith, set a remarkable example for the proceedings of subsequent international tribunals.

${ }^{354}$ Justice Case, above n 9, 5 .

355 Ibid, 4-5.

${ }^{356}$ Ibid, 5. 


\section{A The Creation of a New International Criminal Law}

The charges against the defendants in the Justice Trial were based on the crimes defined in Article II section (1) of Allied Control Council Law No. 10, which by itself had its origins in the London Agreement and the London Charter. ${ }^{357}$ Herein, the Allies had established four new categories of crimes to try and punish the German war criminals: (a) crimes against peace; (b) war crimes; (c) crimes against humanity; and (d) membership in criminal organisations. ${ }^{358}$

Especially the categories of crimes against peace and crimes against humanity became a target of heavy criticism by many legal experts, ${ }^{359}$ but only the category of crimes against humanity is relevant here as no defendant in the Justice Trial was charged with crimes against peace.

The criticism and also the arguments of the defence, not only in the Justice Trial but in all Nuremberg Trials were based on two principal subjects: (1) the violation of the ex post facto principle; and (2) the excuse of just obeying superior orders in relation to the issue of individual liability. ${ }^{360}$ Additionally, the $t u$ quoque argument was raised and questioned the legitimacy of the whole concept of the Allied war crimes trials programme. $^{361}$

\footnotetext{
${ }^{357}$ See Part II A 1 (b) London Agreement of 8 August 1945, Part II A 1 (c) Charter of the International Military Tribunal and Part II A 1 (d) Allied Control Council Law No 10.

${ }^{358}$ See Part II A 1 (d) Allied Control Council Law No 10.

${ }^{359}$ See for example Maugham, above n 49, 25-39; and John H Morgan The Great Assize: An Examination of the Law of the Nuremberg Trials (John Murray, London, 1948) 19-38.

${ }^{360}$ Bassiouni, above n 4, 537-538.

${ }^{361} \mathrm{Ibid}, 525,554$.
} 


\section{The charges and their development}

In his opening statement for the Justice Trial, Chief Prosecutor Telford Taylor declared: ${ }^{362}$

... the root of the accusation here is that those men, leaders of the German judicial system, consciously and deliberately suppressed the law, engaged in an unholy masquerade of brutish tyranny disguised as justice, and converted the German judicial system to an engine of despotism, conquest, pillage, and slaughter.

The indictment of the trial contained 34 allegations, which were arranged under four counts: (a) conspiracy to commit war crimes and crimes against humanity; (b) war crimes; (c) crimes against humanity; and (d) membership in criminal organisations. ${ }^{363}$ All defendants were charged with the first three counts, only seven of the defendants were charged with the fourth count. ${ }^{364}$

Basically, the indictment charged the defendants with participation in a common design involving the assumption by the Ministry of Justice of total control over the administration of justice and the use of the judicial process as a weapon for the persecution and extermination of all opponents of the Nazi regime and for the persecution and extermination of races. ${ }^{365}$

Taylor outlined the core of the charges in his opening statement as follows: $:^{366}$

In summary, the defendants are charged with judicial murder and other atrocities which they committed by destroying law and justice in Germany, and by then utilizing the emptied forms of legal process for persecution, enslavement, and extermination on a vast scale.

362 Justice Case, above n 9, 31.

${ }^{363}$ Ibid, 17-26; See also Part III A 2 Independence of the judges from US post-war politics.

${ }^{364}$ Justice Case, above n 9, 17-26.

${ }^{365}$ Katrina Gustafson "Altstoetter and others (The Justice Trial)" in Antonio Cassese (ed) The Oxford Companion to International Criminal Justice (Oxford University Press, Oxford, 2009) 582.

${ }^{366}$ Justice Case, above n 9, 32-33. 
And in an essay, written in 1949 and part of his Final Report, he added more specifically: ${ }^{367}$

\begin{abstract}
The indictment charged that the defendants in the Ministry of Justice had participated in drafting and enacting unlawful orders and decrees, such as those which discriminated against Poles, Jews, and others in occupied territory, and the notorious 'Nacht und Nebel' (Night and Fog) decree under which civilians in the occupied territories were spirited away to Germany for secret trial before special 'courts. ${ }^{368}$ The defendants were also charged with imprisoning and killing Jews, and other members of groups to which the Nazis were hostile, by trials which were a flagrant travesty of the judicial process, and divers other offenses.
\end{abstract}

(a) Conspiracy to commit war crimes and crimes against humanity

All defendants were charged with conspiracy to commit war crimes and crimes against humanity, and the unlawful participation in the formulation and execution of plans to commit war crimes and crimes against humanity. 369

As mentioned before, the conspiracy charge was a favourite of the American prosecution at Nuremberg. ${ }^{370}$ It was introduced in the London Charter against the resistance of the French and Soviet delegations, and it became the count for which the American prosecutors took responsibility at the trial before the International Military Tribunal. ${ }^{371}$ Consequently, the charge of conspiracy also became an important part of the indictment at the Justice Trial.

Attacked by legal experts during the trial of the major war criminals before the International Military Tribunal already, it was mainly criticised that the concept of conspiracy was a new one to continental law and had

${ }^{367}$ Taylor Final Report, above n 169, 169-170.

${ }^{368}$ See Part V A General Remarks.

${ }^{369}$ Gustafson, above n 365, 582; Justice Case, above n 9, 17-19.

${ }^{370}$ See Part III A 2 Independence of the judges from US post-war politics.

${ }^{371}$ Ibid. 
developed in Anglo-Saxon law only. ${ }^{372}$ Furthermore, the critics argued that "members and leaders of bands of criminals may be made responsible for all crimes of the band, even if they cannot be shown to have participated actively in each individual crime", but in the case of Nazi crimes it "does not provide any clear limit and is too little adapted to political reality" as it would "make every leading National Socialist responsible for all crimes of the regime." 373

On these grounds, the charge of conspiracy was objected by the defence in several cases of the subsequent Nuremberg Trials. ${ }^{374}$ On 9 July 1947, five US military tribunals, including Tribunal III which was in charge for the Justice Trial, held a joint session to hear the arguments of both defence and prosecution in regard to the sufficiency of counts, which charged defendants with conspiracy to commit war crimes and crimes against humanity as a separate offence. ${ }^{375}$

In the end, Military Tribunal III disregarded the count, because it found that it had no jurisdiction under the London Charter or Control Council Law No. 10 to try conspiracy as a substantive crime. ${ }^{376}$ Additionally, the Tribunal stated: ${ }^{377}$

This Tribunal has held that it has no jurisdiction to try any defendant for the crime of conspiracy as a separate substantive offense, but we recognize that there are allegations in count one of the indictment which constitute charges of direct commission of war crimes and crimes against humanity. However, after eliminating the conspiracy charge from count one, we find that all other alleged criminal acts therein set forth and committed after 1 September 1939 are also charged as crimes in the subsequent counts of the indictment. We therefore find it unnecessary to pass formally upon the remaining charges in count one. Our pronouncements of guilt or innocence under counts two, three, and four dispose of all issues which have been submitted to us.

\footnotetext{
${ }^{372}$ Ehard, above n 161, 81.

${ }^{373}$ Ibid.

${ }^{374}$ See generally United Nations War Crimes Commission, above n 223, 104-110; See also Haensel, above n 161, 198-199.

${ }^{375}$ United Nations War Crimes Commission, above n 223, 104.

376 Justice Case, above n 9, 956; Gustafson, above n 365, 582-583; See also Part III A 2 Independence of the judges from US post-war politics.

${ }^{377}$ Justice Case, above n 9, 1177.
} 
Thus, in the view of Military Tribunal III, the lack of jurisdiction did not lead to a lack of punishment of certain actions of the defendants, because those actions were also covered by the other counts.

Nevertheless, it is important to note that count one included crimes committed in the period between January 1933, the time when the Nazis took over power in Germany, and April 1945, the time when World War II came to an end, whereas the other counts charged only crimes committed between September 1939, the start of the war, and April 1945. ${ }^{378}$ As a result, the judgment of the Justice Trial, at the end, was limited to crimes committed during World War II, and did not include any evaluation of actions of the defendants in times of peace.

(b) War crimes

Count two charged all the defendants with war crimes, including plunder, murder, torture, illegal imprisonment and brutalities, atrocities and other inhumane acts, against thousands of civilians of territories occupied by Germany during the war and against soldiers of countries at war with Germany, committed during the period between September 1939 and April $1945 .^{379}$

The main allegations were that the Ministry of Justice had participated in the execution of Hitler's Night and Fog Decree and the Nazi programme of racial purity, had aided and implemented the unlawful annexation and occupation of Czechoslovakia, Poland and France, and had granted immunity to and amnesty for Nazi Party members who had been prosecuted and convicted of major crimes. ${ }^{380}$

Codified for the first time in international law by Article 6 (b) of the London Charter and Article II section (1) (b) of Control Council Law No.

\footnotetext{
${ }^{378}$ Ibid, 955; See generally Ibid, 17-26.

${ }^{379}$ Gustafson, above n 365, 582; Justice Case, above n 9, 19.

${ }^{380}$ Justice Case, above n 9, 20-22; See also Part V A General Remarks.
} 
$10,^{381}$ this count was less subject to legal controversies during the Nuremberg Trials than other charges, because it was principally based on well-established traditional law like the Hague Convention of 1907 and annexed regulations concerning the laws and customs of war on land. ${ }^{382}$

However, it established individual criminal responsibility at the international level, whereas the Hague Regulations of 1907 had provided that only states could be liable for compensation for acts committed by members of their armed forces. ${ }^{383}$

In its judgment, Military Tribunal III evaluated the concept of war crimes as established in the London Charter and Control Council Law No. 10 not as the creation of a new offence, but the first extensive embodiment of acts in violation of the laws and customs of war. ${ }^{384}$ It stated: ${ }^{385}$

\footnotetext{
Here we observe the controlling effect of common international law as such, for the statutes by which we are governed have adopted and incorporated the rules of international law as the rules by which war crimes are to be identified.
}

The concept of war crimes was limited to cover criminal acts against non-Germans only and, therefore, did not include atrocities committed by Germans against their own nationals. ${ }^{386}$ According to Tribunal III, this was expressed very clearly in Article 6 of the London Charter which restricted the listed acts of war crimes towards the population, soldiers or property "of or in occupied territory" only. ${ }^{387}$

\footnotetext{
${ }^{381}$ Charter of the International Military Tribunal, above n 42, art 6 (b); Control Council Law No. 10 1945, above n 55, art II s (1) (b); See also Part II A 1 (c) Charter of the International Military Tribunal and Part II A 1 (d) Allied Control Council Law No. 10.

${ }^{382}$ Beigbeder, above n 20, 44

${ }^{383}$ Ibid; See also Part IV A 3 Individual liability.

${ }^{384}$ Justice Case, above n 9, 971-972.

${ }^{385} \mathrm{Ibid}, 971$.

${ }^{386}$ Ibid, 971-972; See generally Charter of the International Military Tribunal, above n 42, art 6 (b); Control Council Law No. 10 1945, above n 55, art II s (1) (b); See also Part II A 1 (c) Charter of the International Military Tribunal and Part II A 1 (d) Allied Control Council Law No. 10.

${ }^{387}$ Justice Case, above n 9, 972.
} 
Similarly, the Tribunal interpreted Article II section (1) (b) of Control Council Law No. 10, which at one place limited several war crimes acts towards the "civilian population from occupied territory.",388

(c) Crimes against humanity

Under count three, all defendants were charged with crimes against humanity, including murder, extermination, enslavement, deportation, illegal imprisonment, torture, persecution on political, racial and religious grounds, ill-treatment and other inhumane acts against German civilians and nationals of occupied territories, committed between September 1939 and April $1945 .^{389}$

The allegations were basically similar to those charged under count two, with the addition of the accusation that special health courts perverted eugenic and sterilisation laws or policies which resulted in the systematic murder and ill-treatment of thousands of persons, and the accusation that German family and inheritance laws were changed by the Ministry of Justice for the sole purpose of confiscating Jewish properties. ${ }^{390}$ Count three, therefore, was wider than count two and, most notably, included criminal acts committed against German nationals. ${ }^{391}$

The charges of count three were based on Article 6 (c) of the London Charter and Article II section (1) (c) of Control Council Law No. 10. ${ }^{392}$ When looking at the definitions of war crimes and crimes against humanity in these regulations, it becomes clear that war crimes may also constitute

\footnotetext{
388 Ibid.

${ }^{389}$ Gustafson, above n 365, 582; Justice Case, above n 9, 23.

${ }^{390}$ Justice Case, above n 9, 24, 25.

${ }^{391}$ United Nations War Crimes Commission, above n 223, 79.

${ }^{392}$ See generally Charter of the International Military Tribunal, above n 42, art 6 (c); and Control Council Law No. 10 1945, above n 55, art II s (1) (c); See also Part II A 1 (c) Charter of the International Military Tribunal and Part II A 1 (d) Allied Control Council Law No. 10.
} 
crimes against humanity, because the same offences may amount to both types of crime. ${ }^{393}$

Yet, the concept of crimes against humanity is broader than war crimes in that criminal acts can be committed in either peace or war against one's own citizens. ${ }^{394}$ In its judgment, Military Tribunal III stated: ${ }^{395}$

[The sections of crimes against humanity as defined in the London Charter and Control Council Law No. 10] supplement the preceding sections on war crimes and include within their prohibition not only war crimes, but also acts not included within the preceding definition of war crimes. In place of atrocities committed against civilians of or in or from occupied territory, these sections prohibit atrocities 'against any civilian population'. ... C.C. Law 10 clearly demonstrates that acts by Germans against German nationals may constitute crimes against humanity within the jurisdiction of this Tribunal to punish.

However, Tribunal III also narrowed down the scope of crimes against humanity by saying that isolated offences do not constitute crimes against humanity, and that the proof of systematic governmental organisation of the acts is a necessary element of the crime. It stated: ${ }^{396}$

We hold that crimes against humanity as defined in C.C. Law 10 must be strictly construed to exclude isolated cases of atrocity or persecution whether committed by private individuals or by governmental authority. As we construe it, that section provides for punishment of crimes against German nationals only when there is proof of conscious participation in systematic government organized or approved procedures amounting to atrocities and offenses of the kind specified in the act and committed against populations or amounting to persecutions on political, racial, or religious grounds.

The concept of crimes against humanity was discussed among legal experts before, during and after the Nuremberg Trials. Prior to Nuremberg,

\footnotetext{
${ }^{393}$ United Nations War Crimes Commission, above n 223, 79.

${ }^{394}$ Otto Kranzbuehler "Nuremberg as a Legal Problem" in Wilbourn E Benton and Georg Grimm (eds) Nuremberg: German Views of the War Trials (Southern Methodist University Press, Dallas, 1955) 118.

${ }_{395}^{3}$ Justice Case, above n 9, 972-973.

${ }^{396}$ Ibid, 982.
} 
crimes against humanity did not exist as a legal category. ${ }^{397}$ It was codified for the first time in the London Charter for the International Military Tribunal, because some of the atrocities committed by the Nazis during World War II, such as the planned and systematic persecution and extermination of the European Jews and Gypsies and many other inhumane acts based on political, racial or religious grounds, did not qualify as war crimes under existing international law. ${ }^{398}$

Yet, there was uncertainty whether the new concept of crimes against humanity as established in the London Charter was just the codification of common international law or the creation of something completely new. ${ }^{399}$

Critics like Otto Kranzbuehler, a German lawyer who represented Grand Admiral Karl Doenitz in the trial against the major war criminals before the International Military Tribunal, and who was one of the leading defenders in the cases of the subsequent Nuremberg Trials against the German industrialists Friedrich Flick (Case 5) and Alfried Krupp (Case $10),{ }^{400}$ stated that the typical feature of this crime was its characterisation as a governmental crime and, therefore, "the acceptance of this crime necessarily includes the liability of the perpetrators, namely the government." $" 401$ As a result, he argued: "Such a crime clearly offers a possibility for intervention by any foreign power in the domestic policy of a defeated country before and during the war, depending only on vastly undefined moral concepts." ${ }^{402}$

\footnotetext{
${ }^{397}$ Sheri P Rosenberg "The Nuremberg Trials: A Reappraisal and their Legacy" (2006) 27 Cardozo L Rev 1549, 1550; See also Mark Aarons "Justice Betrayed: Post-1945 Responses to Genocide" in David A Blumenthal and Timothy L H McCormack (eds) The Legacy of Nuremberg: Civilising Influence or Institutionalised Vengeance? (Martinus Nijhoff Publishers, Leiden, 2008) 73.

${ }^{398}$ Rosenberg, above n 397, 1550; Beigbeder, above n 20, 47.

${ }^{399}$ Bassiouni, above n 4, 535-536.

${ }^{400}$ International Military Tribunal I, above n 1, 6; The United States of America v Friedrich Flick and others (Flick Case) (1947) VI Trials of War Criminals before the Nuernberg Military Tribunals under Control Council Law No. 10 (Case No 5) 9; The United States of America v Alfried Krupp and others (Krupp Case) (1947-1948) IX Trials of War Criminals before the Nuernberg Military Tribunals under Control Council Law No. 10 (Case No 10) 6.

${ }^{401}$ Kranzbuehler, above n 394, 118-119.

${ }^{402}$ Ibid, 119.
} 
In Kranzbuehler's view, the concept of crimes against humanity was a new one and violated international law by granting foreign governments the right to interfere into a state's sovereignty. ${ }^{403}$ Military Tribunal III had a different view. It stated: ${ }^{404}$

The force of circumstance, the grim fact of world-wide interdependence, and the moral pressure of public opinion have resulted in international recognition that certain crimes against humanity committed by Nazi authority against German nationals constituted violations not alone of statute but also of common international law.

Regarding the novelty of crimes against humanity and the possibility of interventions into another state's sovereignty, it is true that the codification of the concept was new. However, historically, the concept was not new at all.

In 1827, for example, England, France and Russia intervened in the Greco-Turkish warfare to end the atrocities; ${ }^{405}$ in 1840 , President Van Buren intervened in Turkish affairs on behalf of the prosecuted Jews of Damascus and Rhodes; ${ }^{406}$ in 1861 , the French intervened in Lebanon to check on religious atrocities; ${ }^{407}$ and in 1915, during World War I, a joint declaration of Great Britain, France and Russia explicitly described the Turkish massacres of Armenians as "crimes against humanity and civilisation."408 Additionally, the first Hague Convention of 1899 on Laws and Customs of War on Land invoked humanity as a norm and, according to Caroline Fournet, considered "'the laws of humanity' as being the mould of 'principles of international law.",409

\footnotetext{
${ }^{403}$ Ibid, 119; See also Part II A 2 (b) The issue of Germany's remaining sovereignty.

${ }^{404}$ Justice Case, above n 9, 979.

${ }^{405} \mathrm{Ibid}, 981$.

${ }^{406}$ Ibid.

${ }^{407}$ Ibid.

${ }^{408}$ Caroline Fournet International Crimes: Theories, Practice and Evolution (Cameron May, London, 2006) 27.

${ }^{409}$ Ibid.
} 
Also, it is a matter of fact that the elements of the newly defined crimes against humanity were similar to those which constituted murder, torture, rape and other atrocities that were and are universally proscribed. ${ }^{410}$

In the end, therefore, it cannot be said that the concept of crimes against humanity was something completely new or unknown prior to 1945 . Faced with the horrors committed during World War II, the Allies were not to repeat their failure in regard of punishing war criminals after World War I, and created the London Charter to let the existing concept of crimes against humanity finally emerge into positive international law. ${ }^{411}$

Military Tribunal III concluded its evaluation of this issue with the following statement, which is a good summary of the outcome of the legal analysis above: ${ }^{412}$

\begin{abstract}
Whether the crime against humanity is the product of statute or of common international law, or, as we believe, of both, we find no injustice to persons tried for such crimes. They are chargeable with knowledge that such acts were wrong and were punishable when committed.
\end{abstract}

(d) Membership in criminal organisations

Seven of the defendants were charged with membership in an organisation declared criminal by the International Military Tribunal. The charges were based on Articles 9 and 10 of the London Charter, and Article II section (1) (d) of Control Council Law No. 10. ${ }^{413}$

In its judgment, the International Military Tribunal had declared the following Nazi organisations as criminal: the Leadership Corps of the Nazi

\footnotetext{
${ }^{410}$ Aarons, above n 397, 73.

${ }^{411}$ Fournet, above n 408, 29.

${ }^{412}$ Justice Case, above n 9, 983.

${ }^{413}$ See generally Charter of the International Military Tribunal, above n 42, arts 9, 10; Control Council Law No. 10 1945, above n 55, art II s (1) (d); See also Part II A 1 (c) Charter of the International Military Tribunal and Part II A 1 (d) Allied Control Council Law No. 10.
} 
Party, the Gestapo, ${ }^{414}$ the $\mathrm{SD}^{415}$ and the $\mathrm{SS}^{416}$. Altstoetter, Cuhorst, Engert and Joel were charged with membership in the SS; Cuhorst, Oeschey, Nebelung and Rothaug were charged with membership in the Leadership Corps of the Nazi Party; and Joel was charged with membership in the $\mathrm{SD}^{417}$

The count was criticised by legal experts for that it was based purely on the judgment of the International Military Tribunal and, according to the famous British General and lawyer J H Morgan, "the 'views' of a military tribunal can neither change International Law nor create it." 418

Yet, it has to be asked, in absence of a world authority in 1945, who if not this tribunal, which consisted of members of the four most powerful countries at the time and, furthermore, was fully authorised by the Governments of those four and 19 other countries who had signed the London Agreement, should have been able to judge instead. ${ }^{419}$

However, the International Military Tribunal itself limited the use of the count only to persons who had knowledge of the criminal purposes or acts of the organisation, and those who voluntarily became members and were not drafted by the State for membership. ${ }^{420}$ The Tribunal introduced a test to determine the guilt or innocence of an individual member of a

\footnotetext{
414 The Gestapo was the secret state police of Nazi Germany, responsible for the elimination of any opposition to the Nazis within Germany and its occupied territories. It was also responsible for the roundup of Jews throughout Europe and their deportation into extermination camps. "Gestapo" www.britannica.com (last accessed 17 March 2010).

415 "The Sicherheitsdienst des Reichsfuehrers-SS (commonly known as the $S D$ ), a department of the SS, was developed into a vast espionage and counter-intelligence system which operated in conjunction with the Gestapo and criminal police in detecting, suppressing and eliminating tendencies, groups and individuals deemed hostile or potentially hostile to the Nazi Party, its leaders, principles and objectives, and eventually was combined with the Gestapo and criminal police in a single security police department, the Reich Main Security Office." International Military Tribunal I, above n 1, 82.

${ }^{416}$ The Schutzstaffeln der NSDAP (commonly known as the $S S$ ) was an elite corps of the Nazi Party, consisting of many sub-departments, including the SD. Founded by Hitler in 1925 as a small personal bodyguard, it developed into the most powerful and brutal force of Nazi Germany, dealing with military, policy, and racial matters. During World War II, the SS carried out massive executions of political opponents, Gypsies, Jews, Polish leaders, Communist authorities, partisan resisters and Russian prisoners of war. "SS" www.britannica.com (last accessed 17 March 2010).

${ }^{417}$ Justice Case, above n 9, 25-26.

${ }^{418}$ Morgan, above n 359, 8.

${ }^{419}$ See Part II A 1 (b) London Agreement of 8 August 1945.

${ }^{420}$ International Military Tribunal I, above n 1, 256.
} 
criminal organisation. Hereafter, members were to be declared criminal only when they ${ }^{421}$

became or remained members of the organisation with knowledge that it was being used for the commission of acts declared criminal by Article 6 of the Charter, or ... were personally implicated as members of the organisation in the commission of such crime.

As a result, the final decision whether the individual member was guilty or not always remained at the respective court's own discretion. ${ }^{422}$ Therefore, although just membership in a specific organisation could bring one to trial, the count itself cannot be evaluated as a violation of international law as the decision for guilt or innocence exclusively depended on the member's personal contribution to the crimes committed by the organisation.

In its judgment, Military Tribunal III, furthermore, demonstrated clearly that the decision of the International Military Tribunal in respect to criminal organisations had no bias and the courts retained their independence. It stated: ${ }^{423}$

C.C. Law 10 provides that we are bound by the findings as to the criminal nature of these groups or organisations. However, it should be added that the criminality of these groups and organisations is also established by the evidence which has been received in the pending case. Certain of the defendants are charged in the indictment with membership in the following groups or organisations which have been declared and are now found to be criminal, to wit: The Leadership Corps, the SD, and the SS. In passing upon these charges against the respective defendants, the Tribunal will apply the tests of criminality set forth above.

${ }^{421}$ Ibid, 262.

${ }^{422}$ Justice Case, above n 9, 1030.

${ }^{423}$ Ibid, 1031. 
2 The ex post facto principle (nullum crimen sine lege, nulla poena sine lege)

The major point of criticism regarding the Justice Trial and all other Nuremberg Trials was the reproach that the newly defined crimes in the London Charter and Control Council Law No. 10, especially the category of crimes against humanity, violated the principle of nullum crimen sine lege, nulla poena sine lege (no crime without law, no punishment without law). ${ }^{424}$

The doctrine, also known as the ex post facto principle, postulates "that a person may only be held criminally liable and punished if, at the moment when he performed a certain act, the act was regarded as a criminal offence by the relevant legal order." 425

The principle derived from the era of the Enlightenment and reflects the idea of separation of powers after the French political thinker Montesquieu, who basically said that the judiciary must judge only where the legislation had enacted a corresponding law to protect the individual as the owner of inherent inviolable rights from unforeseeable and arbitrary use of power by the state. ${ }^{426}$

The German penal code, created in 1871 and with many amendments used ever since, holds onto this principle until today. ${ }^{427}$ Only during the Nazi regime was the principle suspended from German criminal law. ${ }^{428}$

Thus, it is an irony of fate that the defendants in the Justice Trial claimed protection under this principle, although they ignored it as a

\footnotetext{
${ }^{424}$ Friedman, above n 2, 81; Bassiouni, above n 4, 526.

${ }^{425}$ Antonio Cassese "Nullum Crimen Sine Lege" in Antonio Cassese (ed) The Oxford Companion to International Criminal Justice (Oxford University Press, Oxford, 2009) 438.

${ }^{426}$ Lore Maria Peschel-Gutzeit and Anke Jenckel "Aktuelle Bezuege des Nuernberger Juristenurteils: Auf welchen Grundlagen kann die deutsche Justiz das Systemunrecht der DDR aufarbeiten?" in Lore Maria Peschel-Gutzeit Das Nuernberger Juristen-Urteil von 1947 (Nomos Verlag, Baden-Baden, 1996) 279.

${ }^{427}$ German Criminal Code 1871 (as amended on 4 July 2009), ss (1) and (2).

${ }^{428}$ Gesetz zur Aenderung des Strafgesetzbuches vom 28. Juni 1935 (Law Concerning the Alteration of the Penal Code from 28 June 1935) 70 RGBl 1935 I 839, art 1 para (2); See also Justice Case, above n 9, 990.
} 
defence plea during their terms in office and had celebrated its official suspension in 1935 as progress within the Nazi judicature. ${ }^{429}$ Military Tribunal III commented: "The defendants claim protection under the principle nullum crimen sine lege, though they withheld from others the benefit of that rule during the Hitler regime." ${ }^{430}$

Nevertheless, the objections of the defence were understandable from a formal point of view, and the Tribunal extensively dealt with this issue. $^{431}$

The defendants primarily claimed that they had no guilty knowledge, which means that they lacked any feeling of doing wrong because they acted in conformity with the given law, and argued that "heute nicht Unrecht sein kann, was gestern Recht war" (it cannot be wrong today, what was right yesterday). ${ }^{432}$

Against this, Military Tribunal III stated as follows: ${ }^{433}$

Under written constitutions the ex post facto rule condemns statutes which define as criminal, acts committed before the law was passed, but the ex post facto rule cannot apply in the international field as it does under constitutional mandate in the domestic field. Even in the domestic field the prohibition of the rule does not apply to the decisions of common law courts, though the question at issue be novel. International law is not the product of statute for the simple reason that there is as yet no world authority empowered to enact statutes of universal application. International law is the product of multipartite treaties, conventions, judicial decisions and customs which have received international acceptance or acquiescence. It would be sheer absurdity to suggest that the ex post facto rule, as known to constitutional states, could be applied to a treaty, a custom, or a common law decision of an international tribunal, or to the international acquiescence which follows the event. To have attempted to apply the ex post facto principle to judicial decisions of common international law would have been to strangle that law at birth.

\footnotetext{
429 Susanne Schott "Curt Rothenberger: Eine politische Biographie" (PhD Thesis, University of Halle-Wittenberg, Germany, 2001) 163.

${ }^{430}$ Justice Case, above n 9, 974.

${ }^{431}$ See generally Ibid, 974-979.

${ }^{432}$ Kastner "Der Dolch des Moerders war unter der Robe des Juristen verborgen: Der Nuernberger Juristen-Prozess 1947”, above n 317, 701.

${ }^{433}$ Justice Case, above n 9, 974-975.
} 
This argument in favour of the non-applicability of the ex post facto principle in international law was shared by the International Military Tribunal and many legal experts. ${ }^{434}$

The legal theorist and German jurist Gustav Radbruch agreed that the principle could not be applied in the cases at Nuremberg, but he argued with a different approach which became known as the Radbruch Formula. ${ }^{435}$ Emerging from the public dispute over the role of law in Nazi Germany between the theories of naturalism, which "seeks to connect law with a higher moral code" 436 , and positivism, which "is content to identify

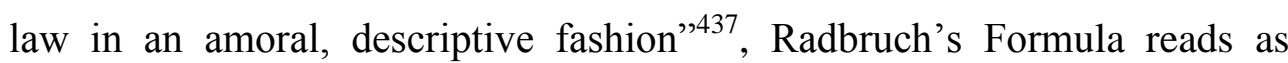
follows: $:^{438}$

The conflict between justice and legal certainty may well be resolved in this way: The positive law, secured by legislation and power, takes precedence even when its content is unjust and fails to benefit the people, unless the conflict between statute and justice reaches such an intolerable degree that the statute, as 'flawed law', must yield to justice. It is impossible to draw a sharper line between cases of statutory lawlessness and statutes that are valid despite their flaws. One line of distinction, however, can be drawn with utmost clarity: Where there is not even an attempt at justice, where equality, the core of justice, is deliberately betrayed in the issuance of positive law, then the statute is not merely 'flawed law', it lacks completely the very nature of law. For law, including positive law, cannot be otherwise defined than as a system and an institution whose very meaning is to serve justice.

In short, Radbruch's Formula can be expressed as follows: Although appropriately enacted and socially effective, laws lose their legal character or their legal validity when they are extremely unjust. Radbruch had developed this approach exclusively in respect to the Nazi laws and

\footnotetext{
${ }^{434}$ Ibid, $975-979$

${ }^{435}$ See generally Gustav Radbruch "Statutory Lawlessness and Supra-Statutory Law (1946)" translated by Bonnie Litschewski-Paulson and Stanley L Paulson (2006) 26 Oxford J Legal Stud 1, 1 et seq.

${ }^{436}$ Grant Morris Law Alive: The New Zealand Legal System in Context (Oxford University Press, Oxford, 2008) 158; See also generally H L A Hart "Positivism and the Separation of Law and Morals" (1958) 71 Harv L Rev 593, 593 et seq; and Lon L Fuller "Positivism and Fidelity to Law: A Reply to Professor Hart" (1958) 71 Harv L Rev 630, 630 et seq.

${ }^{437}$ Ibid.

${ }^{438}$ Radbruch, above n 435, 7.
} 
concluded: "Measured by this standard, whole portions of National Socialist law never attained the dignity of valid law."439

Similar views were expressed by other legal experts, ${ }^{440}$ but Radbruch's Formula gained universal attention and was applied by several courts in later trials, for example, by German civil courts in the Wallshooters' trials after the unification of Germany. ${ }^{441}$

With respect to the Radbruch Formula, the validity of positive law is not unrestricted. When justice is violated in an extreme manner, statutes can turn into non-law and, in reverse, non-law can turn into positive or, at least, applicable law. Consequently, retrospective laws can become applicable if an inadequacy between justice and legal certainty emerges. An example would be, if one is acting in a way that he or she knows is unjust but not punishable and uses the benefits of the ex post facto principle to betray its original aim, the creation of justice.

In both approaches, the non-applicability of the ex post facto principle in international law and the idea of the Radbruch Formula, defendants do not benefit from the principle because it has to stand back in favour of the creation of justice as the ultimate purpose. For the Justice Trial this meant that it had to be balanced out whether the general predictability and undermining of law or an unjust verdict would have been the smaller risk.

Insofar as the defendants acted in the confidence of a penal code that did not recognise their actions as crimes, they were disappointed in their legal certainty by Control Council Law No. 10. This confidence, however, was limited already because representatives of the countries occupied by Germany and the four Allies had declared in multiple official statements throughout the war, starting as early as 1940, that the persons responsible

\footnotetext{
439 Ibid.

${ }^{440}$ See for example Woetzel, who stated: "Since it is an ethical principal rather than a rule of law, it may be set aside if considerations of justice demand it." Woetzel, above n 14, 112.

${ }^{441}$ See generally Horst Dreier "Gustav Radbruch und die Mauerschuetzen" (1997) 52 Juristen Zeitung 421, 421-434; See also Part VI A 2 Criticism and Part VI A 3 Conclusion.
} 
for the atrocities committed in their countries will be punished. ${ }^{442}$ This could not be remained unnoticed by the defendants.

Additionally, as expressed by Sir David Maxwell Fyfe, one of the British prosecutors at the first Nuremberg Trial, the defendants must have been aware of that their actions were criminal: ${ }^{443}$

With regard to 'crimes against humanity', this at any rate is clear: the Nazis, when they persecuted and murdered countless Jews and political opponents in Germany, knew that what they were doing was wrong and that their actions were crimes which had been condemned by the criminal law of every civilised State.

Furthermore, the newly constituted crime against humanity, from its content, corresponded with the existing German penal laws, because deprivation of liberty, battery, rape and murder had always been punishable crimes. ${ }^{444}$ In this context, Military Tribunal III stated: ${ }^{445}$

Many of the laws of the Weimar era which were enacted for the protection of human rights have never been repealed. Many acts constituting war crimes or crimes against humanity as defined in C.C. Law 10 were committed or permitted in direct violation also of the provisions of the German criminal law. It is true that this Tribunal can try no defendant merely because of a violation of the German penal code, but it is equally true that the rule against retrospective legislation, as a rule of justice and fair play, should be no defence if the act which he committed in violation of C.C. Law 10 was also known to him to be a punishable crime under his own domestic law.

After all, a violation of the ex post facto principle by Control Council Law No. 10, therefore, is only a violation in a very formal sense, because no actions were criminalised by the law that were not already punishable before.

\footnotetext{
${ }^{442}$ Baestlein, above n 12, 12; See also Part II A 1 (a) Declaration on German Atrocities (Moscow Declaration 1943).

${ }^{443}$ Justice Case, above n 9, 976.

${ }^{444}$ Baestlein, above n 12, 12.

${ }^{445}$ Justice Case, above n 9, 977.
} 


\section{$3 \quad$ Individual liability}

The London Charter, for the first time in history, established the rule that individuals are liable for their actions under international criminal law. $^{446}$

There had been efforts before to introduce individual responsibility in international law, for example, the Treaty of Versailles, but the overall failure to prosecute the war criminals after World War I, including the unsuccessful attempt to capture the German Emperor Wilhelm II, led to the stagnation of this concept. ${ }^{447}$ As a result, the Acts of State doctrine remained the dominating principle in international law, meaning that only states are subject to international law and individuals cannot be made responsible for their actions, which they performed as an instrument or organ of the state. ${ }^{448}$

The new approach of the London Charter soon became the target of the defence in all Nuremberg Trials, who claimed that the concept violated international law, and the defendants could be held individually responsible only under national law. ${ }^{449}$ Additionally, the defence in the Justice Trial claimed that the defendants could not be held personally liable, because they were not responsible for the transformation of the German law into an instrument of the Nazis. ${ }^{450}$

Related to the classical plea of just obeying superior orders, it was argued that the different decrees, orders, directives, decisions and instructions had been solely based on the decisions of Hitler. ${ }^{451}$ After the so

\footnotetext{
${ }^{446}$ Charter of the International Military Tribunal, above n 42, arts 6-8; See also Part II A 1 (c) Charter of the International Military Tribunal.

${ }^{447}$ See Part II A 2 (c) (i) Historical experience.

${ }^{448}$ Woetzel, above n 14, 68; See also Part II A 2 (c) (i) Historical experience and Part VI A 1 Development.

${ }^{449}$ Woetzel, above n 14, 104-108; See also International Military Tribunal I, 168-170.

450 Justice Case, above n 9, 1062; See also Hermann Jahrreiss "Statement before the Nuremberg Tribunal" in Wilbourn E Benton and Georg Grimm (eds) Nuremberg: German Views of the War Trials (Southern Methodist University Press, Dallas, 1955) 67-72.

${ }^{451}$ Jahrreis, above n 450, 71-72; See also Part V A 1 (f) The execution of the law in Nazi Germany.
} 
called Fuehrer Principle, which had been established in all governmental areas of Nazi Germany after the Nazis had taken over power, Hitler was the supreme legislator as well as the supreme judge. ${ }^{452}$ His will, therefore, was the final authority, and his orders constituted law directly. ${ }^{453}$

However, there was an unusual consensus among legal experts and the judges of the Nuremberg Tribunals - certainly caused by the growing knowledge about the atrocities committed by the Nazis all over Europe that individuals have to be held responsible for their actions.

Military Tribunal III referred to the judgment of the International Military Tribunal, which had stated as follows: ${ }^{454}$

It was submitted that international law is concerned with the actions of sovereign States, and provides no punishment for individuals; and further, that where the act in question is an act of State, those who carry it out are not personally responsible, but are protected by the doctrine of the sovereignty of the State. In the opinion of the Tribunal, both these submissions must be rejected. That international law imposes duties and liabilities upon individuals as well as upon States has long been recognized ... Crimes against international law are committed by men, not by abstract entities, and only by punishing individuals who commit such crimes can the provisions of international law be enforced.

According to Robert $\mathrm{K}$ Woetzel, an individual may be held responsible for a crime under international law, when it "is an act which injures not only the state against which it is directed, but the whole international community." 455

The different Nuremberg Tribunals argued similarly and "insisted that inhumane acts such as murder, deportation, enslavement, and persecution on the basis of racial and religious grounds shocked the conscience of every decent human being." 456 They concluded "that those

\footnotetext{
${ }^{452}$ Justice Case, above n 9, 1010-1011; See also Part V A 1 (f) The execution of the law in Nazi Germany.

${ }^{453}$ Jahrreiss, above n 450, 67, 72; See also Part V A 1 (f) The execution of the law in Nazi Germany.

${ }^{454}$ Justice Case, above n 9, 1062; International Military Tribunal I, 222-223.

${ }^{455}$ Woetzel, above n 14, 108-109.

${ }^{456}$ Friedman, above n 2, 85.
} 
who participated in such conduct could not claim that they did not realize the illegality of their actions."

Additionally, the Nuremberg Tribunals dealt with the question whether the doctrine of individual liability was legally introduced in international law by the London Charter. Military Tribunal III stated: ${ }^{458}$

\begin{abstract}
International law is not the product of statute. Its content is not static. The absence from the world of any governmental body authorized to enact substantive rules of international law has not prevented the progressive development of that law. After the manner of the English common law it has grown to meet the exigencies of changing conditions. It must be conceded that the circumstance which gives to principles of international conduct the dignity and authority of law is their general acceptance as such by civilized nations, which acceptance is manifested by international treaties, conventions, authoritative textbooks, practice, and judicial decisions.
\end{abstract}

This reasonable argument makes sense, especially when one looks at the new dimensions of crimes committed by Nazi Germany, which were without precedent in world history. ${ }^{459}$

The world community was challenged to make a necessary reaction, and the London Charter as part of the London Agreement was the result of a joint decision of the three most powerful nations at the time, the United States, Great Britain and the Soviet Union, and 19 other nations of the civilised world. ${ }^{460}$ Also, it has to be taken into consideration that Germany practically had lost its self determination after the war, and the existing German Nazi laws were obviously inappropriate to use. ${ }^{461}$

Additionally, in support of individual liability under international law, J H Morgan, generally in opposition to the Nuremberg Trials, may be cited here with a comment he made on the plea of just obeying superior

\footnotetext{
${ }^{457}$ Ibid.

${ }^{458}$ Justice Case, above n 9, 966.

${ }^{459}$ See Part II B The Moral Necessity of the Trial.

${ }^{460}$ See Part II A 1 (b) London Agreement of 8 August 1945.

${ }^{461}$ See Part II A 2 (b) (iii) Evaluation.
} 
orders by the defendants in the trial of the major war criminals before the International Military Tribunal: ${ }^{462}$

The general directive, the 'superior orders', of Hitler were so infamous that any officer with any sense of honour would sooner have died a soldier's death by shooting than obey them. These paladins of the German Army preferred to live - to live only to die a felon's death by hanging. They had had their alternative.

Although not related to the non-military defendants of the Justice Trial, this statement makes clear that the establishment of individual liability under international law was supported by the vast majority of international legal experts.

In the end, the concept of individual liability cannot be seen as a violation of international law and, therefore, also not as an occurrence of victor's justice.

\section{The tu quoque argument}

During the first Nuremberg Trial before the International Military Tribunal, Hermann Goering, the infamous Reichsmarschall and second most powerful Nazi after Hitler, stated: "The victor will always be the judge, and the vanquished the accused." $" 463$

Although this was just another polemic expression of Goering's general opinion about the trial, he, in fact, was right. At Nuremberg, only German war criminals were tried and any charges that the Allies had also committed war crimes and crimes against humanity were rejected by the tribunals as outside the terms of the London Charter and, therefore, outside their mandate. ${ }^{464}$

\footnotetext{
${ }^{462}$ Morgan, above n 359, 16.

${ }^{463}$ Bass, above $\mathrm{n} 21,8$.

${ }^{464}$ Beigbeder, above n 20, 39; See also generally Justice Case, above n 9, 970-971.
} 
As a result, the different tribunals were charged with the pronouncement "that it is wrong to try Germans for crimes while the same crimes have been or are being committed by individuals of other nations."465 This accusation was based on the most classical approach of victor's justice: the argument of tu quoque (you, also), which denounces that the standards of law applied to the defeated Germans were not applied to the victorious Allies. $^{466}$

Article 6 of the London Charter limited the jurisdiction of the International Military Tribunal "to try and punish persons who, acting in the interests of the European Axis countries" only. ${ }^{467}$ The 12 US military tribunals at Nuremberg, including Tribunal III, relied heavily on the Charter and followed the same path. ${ }^{468}$

Nevertheless, it is a matter of fact that the Allies also committed war crimes and crimes against humanity, for example, the American and British strategic bombings on exposed German cities like Hamburg and Dresden in 1945, the failure of American submarines to pick up survivors in the Pacific Ocean, the dropping of the Atomic bombs on Japan by the US Air Force and the numerous atrocities committed by the Russians, including the massacre of Polish soldiers in Katyn Forest and the mistreatment of prisoners of war. $^{469}$

\footnotetext{
Military Tribunal III acknowledged these facts by stating: ${ }^{470}$

It must be admitted that Germans were not the only ones who were guilty of committing war crimes; other violators of international law could, no doubt, be tried and punished by the state of which they were nationals, by
}

\footnotetext{
${ }^{465}$ LaFollette, above n 280, 9; See also Friedman, above n 2, 79-80.

${ }^{466}$ Bassiouni, above n 4, 525-526; Christoph Burchard "Goering and others" in Antonio Cassese (ed) The Oxford Companion to International Criminal Justice (Oxford University Press, Oxford, 2009) 700.

${ }^{467}$ Charter of the International Military Tribunal, above n 42, art 6.

${ }^{468}$ Bassiouni, above n 4, 532.

${ }^{469}$ Robert E Conot Justice at Nuremberg (Harper \& Row, New York, 1983) 452-455; Salman Kazmi "Is Victor's Justice in Nuremberg Trial Justified or Not?" (Publication Quaid-e-Azam Law College, Pakistan, 2006) 3-4; Alexandra Letzel "International Precedent or Victor's Justice" (Writing, University of California Santa Barbara, United States, 2007) 5-8.

${ }_{470}^{\text {Justice Case, above n 9, } 970 .}$
} 
the offended state if it can secure jurisdiction of the person, or by an international tribunal if of competent authorized jurisdiction.

However, it also denied its own jurisdiction for the trial of nonGerman nationals, because Control Council Law No. 10 "is limited" and "specifically directed to the punishment of German criminals."

In his opening speech for the prosecution in the first Nuremberg Trial before the International Military Tribunal, Robert H Jackson had stated: ${ }^{472}$

We must never forget that the record on which we judge these defendants today is the record on which history will judge us tomorrow. To pass these defendants a poisoned chalice is to put it to our own lips as well.

And in another place: ${ }^{473}$

And let me make clear that while this law is first applied against German aggressors, the law includes, and if it is to serve a useful purpose it must condemn aggression by any other nations, including those which sit here now in judgment.

Yet, these high demands were never realised. After World War II, no member of the Allied armed forces had faced criminal responsibility for war crimes, although the Allies were aware of that such had been committed; ${ }^{474}$ Curtis LeMay, an US Air Force pilot who had targeted 63 Japanese cities for annihilation by American bombing, once said: "I suppose if I had lost the war, I would have been tried as a war criminal. Fortunately, we were on the winning side." 475

As a result, it remains that the value of the achievements of Nuremberg is impaired by the failure of the Allies to pursue any prosecution of their own. Therefore, one has to agree with Professor M Cherif Bassiouni who stated: "This is not to say that those who were prosecuted did not

\footnotetext{
${ }^{471}$ Ibid, 972-973.

472 The United States of America, the French Republic, the United Kingdom of Great Britain and Northern Ireland, and the Union of Soviet Socialist Republics v Hermann Wilhelm Goering and others (International Military Tribunal) (1945-1946) II Trial of the Major War Criminals before the International Military Tribunal 101.

${ }^{473}$ Ibid, 154.

${ }^{474}$ Bass, above n 21,8 .

475 Ibid, 8-9.
} 
deserve it, but rather that on the Allies' side there were many similar crimes that warranted prosecution, but were conveniently overlooked." ${ }^{476}$

It is important to say here that such similar crimes were not even close to some of the atrocities committed by Nazi Germany, for example, the organisation and execution of the Holocaust, and therefore, it is not intended to compare German and Allied war crimes on the same level; but under the provisions of the London Charter and Control Council Law No. 10, it is likely that Allied actions, such as the atomic bombing of Japanese cities or the mistreatment of prisoners of war, constituted crimes against humanity.

In his evaluation of the Nuremberg Trials, Otto Kranzbuehler stated: ${ }^{477}$

In the entire public political appraisal of the Nuremberg proceedings one fact must be regarded in the right light: the fact that proceedings of this kind have been, and in the near future will be, conducted against members of defeated nations only.

Although may not intended by the creators of the London Charter, this statement truly describes a negative side of Nuremberg's legacy and confirms the words of Goering.

Hence, the refusal of the Allies to bring to trial members of their own nations, in the end, caused a valid reproach of the Nuremberg Trials as an example of victor's justice.

\section{Conclusion}

The counts within the Justice Trial were based on a code that was legally enacted by the Allies with support from the world community. ${ }^{478}$ The difficulties of punishing war crimes and crimes against humanity under

\footnotetext{
${ }^{476}$ Bassiouni, above n 4, 554.

${ }^{477}$ Kranzbuehler, above n 394, 125.

${ }^{478}$ See Part II A 2 (b) The issue of Germany's remaining sovereignty.
} 
international law before World War II were surmounted by the codification of these laws. Nevertheless, it was widely criticised as a violation of international law.

Indeed, the new criminal concepts changed the traditional international law, but it did not violate it. As shown above, neither was the ex post facto principle, in its basic idea, violated, nor did the establishment of individual responsibility violate any law.

The scope of German atrocities was unique and without precedent in world history and made it necessary to change the antiquated rules of international criminal law. Thus, in respect to the issues of the ex post facto principle and individual liability, the appointment and proceedings of the tribunals at Nuremberg, including Military Tribunal III, were not examples of victor's justice.

A different story, unfortunately, was the refusal of the United States and the other Allied Governments to bring to trial nationals of their own countries for crimes which fell under the same categories of crimes as defined in the London Charter and Control Council Law No. 10, and which the defendants in the Justice Trial were accused of.

This has to be evaluated as an example of victor's justice, because here obviously not the rule of law but the rule of the victors prevailed.

\section{B Fairness of the Trial}

In 1949, the Chief Prosecutor of the subsequent Nuremberg Trials, Telford Taylor, stated in an essay: ${ }^{479}$

The procedures at Nuremberg were largely the product of evolution based on actual experience there. Certainly some difficult and unusual problems arose out of the mixture of different legal systems and the novelty of the

479 Telford Taylor "The Nuremberg War Crimes Trials: An Appraisal" (1949) 23 Proceedings of the Academy of Political Science 19, 24. 
situation, and there is room for honest differences of opinion on a number of points. But the fundamental fairness of the trials was patent to the observer and will, I believe, be apparent to anyone who examines the record of the proceedings.

Indeed, besides some German critics, ${ }^{480}$ there is a broad consensus that the Nuremberg Tribunals were characterised by a sense of fairness and impartiality. ${ }^{481}$ According to Jonathan Friedman, all Nuremberg Trials "adopted numerous safeguards from Anglo-American legal tradition, including the right to counsel, the presumption of innocence, and the rule that conviction is dependent upon proof of the crime beyond a reasonable doubt. ${ }^{, 482}$

Furthermore, in the Justice Trial, the defence was granted free access to the US Army Document Centres, ${ }^{483}$ and the prosecution furnished the defence with German-language copies of their exhibits before they were submitted into evidence. ${ }^{484}$

As a result, the defence in the Justice Trial offered 518 affidavits, of which the prosecution called only three for cross-examination, compared to 76 affidavits offered by the prosecution, of which the defence called $64 .^{485}$ Additionally, the defence offered 1,452 documentary exhibits compared to only 641 of the prosecution; ${ }^{486}$ and from the 138 witnesses heard by the Tribunal, the majority was called by the defence. ${ }^{487}$

In its judgment, Military Tribunal III stated: ${ }^{488}$

Whenever possible, and in substantially all cases, applications of defense counsel for the production in open court of persons who had made affidavits in support of the prosecution, have been granted and the affiants

\footnotetext{
${ }^{480}$ See generally for examples Wilbourn E Benton and Georg Grimm (eds) Nuremberg: German Views of the War Trials (Southern Methodist University Press, Dallas, 1955).

${ }^{481}$ Friedman, above n 2, 79 .

${ }^{482}$ Ibid.

${ }^{483}$ Baestlein, above n 12, 17; See also Part III A 2 Independence of the judges from US post-war politics.

${ }^{484}$ Friedman, above $\mathrm{n} 2,80$.

${ }^{485}$ LaFollette, above n 280, 9.

${ }^{486}$ Justice Case, above n 9, 954.

${ }^{487}$ Ibid.

${ }^{488}$ Ibid.
} 
have appeared for cross examination. Affiants for the defense were cross examined orally by the prosecution in comparatively few cases.

The differences in the numbers can be easily explained by the fact that the captured German documents offered huge amounts of incriminating evidence against the defendants, and the prosecution only needed to present the most serious ones, whereas the defence could hardly find any exonerating material. ${ }^{489}$ However, it shows clearly that the defendants were not handicapped in their defence and, in the end, also the defence counsels in the Justice Trial agreed that the basic principles of due process were not violated at the proceedings. 490

Furthermore, the US administration created a social environment for the defendants and their lawyers, which, compared to the general living conditions in 1947 in the war-damaged city of Nuremberg, could be described as almost luxurious. As described in Telford Taylor's Final Report, the "prison temperature ... the caloric content of the food, and other conditions in the jail" were constantly checked, ${ }^{491}$ and the ${ }^{492}$

\footnotetext{
[d]efense counsel were paid 3,500 RM (Reichsmark) per defendant per month ... Defense counsel who did not live in Nuremberg were provided with billets through arrangements made by the Defense Center. They were also entitled to three meals per day at a cost of only 50 pfennigs per meal, and were issued gratis a carton of cigarettes each per week. They were also provided with office space, furniture, and office supplies in the Palace of Justice. Witnesses requested by defense counsel were procured and were housed, fed, and paid ... without cost to the defense. When defense counsel found it necessary to travel to interview witnesses or for other reasons connected with the trial, railway transportation or the necessary amount of gasoline for privately owned automobiles was furnished free of charge. Extensive clerical and translation assistance, together with a great variety of other services, was also rendered.
}

Nevertheless, besides these positive aspects of the trial-proceedings, two issues were always considered disadvantages for the defendants: firstly,

\footnotetext{
${ }^{489}$ Baestlein, above n $12,17$.

${ }^{490}$ Ibid, 19.

${ }^{491}$ Taylor Final Report, above n 169, 57-58.

${ }^{492}$ Ibid, 49.
} 
that the proceeding was based on the Anglo-American tradition with the tools of examination, cross-examination and re-examination, which the German lawyers were not familiar with; ${ }^{493}$ and secondly, the lack of any appellate instance to affirm or void the judgments. ${ }^{494}$

The missing of an appellate court created a constant headache for the US authorities who wanted the Nuremberg Trials not only as an institution to punish the German war criminals but also as a model to demonstrate the virtue of democracy. ${ }^{495}$ In the end, this problem was solved by the implementation of substitutes, such as the granting of extensive clemency and regular administrative sentence reviews, what turned out to be only advantageous for the convicted defendants of the Justice Trial, as they were all released early from prison in the 1950s. ${ }^{496}$

The other aspect, the unfamiliarity of the defence counsels with the Anglo-American style of procedure, concerned many jurists before the start of the trial. However, the fact that the Tribunal was established as an international and not a German court, ${ }^{497}$ and the ability of the defence to cope with the proceedings, let the initial disadvantage vanish.

According to Henry L Stimson, ${ }^{498}$

the law demands three things: that the defendant be charged with a punishable crime; that he have full opportunity for defense; and that he be judged fairly on the evidence by a proper judicial authority. Should it fail to meet any of these three requirements, a trial would not be justice.

A show trial, on the other hand, Gary J Bass describes as follows: ${ }^{499}$

[A] show trial has no chance of returning an acquittal, keeps the judges in thrall to the prosecution and behind that the state, cares little for

\footnotetext{
${ }^{493}$ Baestlein, above n 12, 19; See generally Military Ordinance No. 7 1946, above n 68; See also Part II A 1 (e) Ordinance No. 7 of the US Military Government for Germany.

${ }^{494}$ Buscher, above n 72, 21; See also Part VI B 3 The amnesties of the 1950s.

${ }^{495}$ Buscher, above n 72, 2; See also Part II B The Moral Necessity of the Trial.

${ }^{496}$ Buscher, above n 72, 22; See also Part VI B 3 The amnesties of the 1950s.

${ }^{497}$ See Part II A 2 (c) (ii) The violation of the principle of separation of powers.

${ }^{498}$ Marrus The Nuremberg War Crimes Trial 1945-1946: A Documentary History, above n 159, 244.

${ }^{499}$ Bass, above n 21, 16.
} 
procedure or standards of evidence, and has a propensity toward the quick execution.

When looking at these definitions, the proceedings of the Justice Trial have to be considered as fair. The defendants were charged with punishable crimes, and they received a fair proceeding. Although naturally disadvantaged by a lack of experience with some rules of the AngloAmerican procedures, the defendants and their lawyers received the same privileges as the prosecution and, therefore, were granted all benefits which constitute a fair trial.

Additionally, it has been shown already that Military Tribunal III acted independently and impartially. ${ }^{500}$ Hence, the overall outcome is that the defendants were treated fairly in all aspects of a modern trial.

Furthermore, the release of the protocols of the Justice Trial and of all other Nuremberg Trials in the volumes of the so called Blue, Red and Green Series established their methods of procedure as an example for later tribunals in international criminal law, ${ }^{501}$ and simultaneously, disprove the assumption that trials initiated by the winners of a war are always show trials and an example of victor's justice.

\footnotetext{
${ }^{500}$ See Part III A The Tribunal.

${ }^{501}$ The Nuremberg Trials are well documented in four major publications: The 42 volumes of the so called Blue Series contain the official proceedings of the trial of the major war criminals; additionally, the eight volumes of the so called Red Series cover the evidence and guide materials from that trial; the official condensed record of the subsequent trials is published in 15 volumes of the so called Green Series; and, eventually, a final report on all the war crimes trials held in Nuremberg from 1945 to 1949 was issued by the Chief of Counsel for War Crimes, Brigadier General Telford Taylor. "Nuremberg Trials" www.loc.gov/rr/frd (last accessed 18 March 2010).
} 


\section{JUDGMENT OF THE TRIBUNAL}

In the Justice Trial, like in all other Nuremberg Trials, the judgment was not only about punishing war criminals, it was also a profound analysis and evaluation of the atrocities done in the name of law in Nazi Germany and of the involvement of the legal profession.

At first, this chapter examines the analysis of the Nazi legal system carried out by Military Tribunal III and deals with the question whether victor's justice occurred due to a distorted illustration of the laws and legal practice of Nazi Germany. It will be concluded that the Tribunal undertook a very careful examination by reflecting only on the given facts without making things out to be worse or better, and therefore, there is no sign of victor's justice on this issue.

Secondly, this chapter investigates whether the Tribunal evaluated the defendants' role in the Nazi legal system, upon which the final judgment was based on, appropriately, and whether the convicted defendants received adequate sentences. A conclusion will be drawn stating that the analysis of the Tribunal had been impressively accurate and, moreover, the sentences have to be seen as very moderate compared to the individual guilt of some of the defendants, and compared to sentences which were given in other Nuremberg Trials.

\section{A General Remarks}

Germany's development from a democracy into one of the harshest dictatorships on earth was perfectly recorded in many documents issued by 
the Nazi officials themselves. ${ }^{502}$ Additionally, the racist and unlawful laws enacted by the Nazi Government were published and available at all times.

The evidence of the prosecution in the Justice Trial, therefore, was based mainly on contemporaneous documents discovered in German archives by the Allies after the war, and on many discriminatory Nazi laws which spoke for themselves. ${ }^{503}$

In analysing these laws and documents, Tribunal III had not much opportunity but keeping to the true facts. It stated: "In rendering this judgment it should be said that the case against the defendants is chiefly based upon captured German documents, the authenticity of which is unchallenged." 504

\section{The Tribunal's analysis of the German law under the Nazis}

The defendants in the Justice Trial argued that they could not be convicted because they had acted within the authority and by the command of German laws and decrees. ${ }^{505}$

The Tribunal referred to Control Council Law No. 10, which provided punishment for crimes against humanity "whether or not the acts were in violation of the domestic laws of the country where perpetrated."506 It then stated: ${ }^{507}$

\footnotetext{
502 Taylor Final Report, above n 169, 50.

503 Justice Case, above n 9, 311.

${ }^{504}$ Ibid, 955.

${ }^{505}$ Herbert Thiele-Fredersdorf "The Judgment of Military Tribunal III in the Nuremberg Trial of Justices" in Wilbourn E Benton and Georg Grimm (eds) Nuremberg: German Views of the War Trials (Southern Methodist University Press, Dallas, 1955) 140. This claim was a valid one under the approach of Positivism, but not under the approaches of Naturalism and the Radbruch Formula. See Grant Morris, above n 436, 158; and see generally Hart, above n 436, 593 et seq; Fuller, above n 436, 630 et seq; See also Part IV A 2 The ex post facto principle (nullum crimen sine lege, nulla poena sine lege).

${ }^{506}$ Justice Case, above n 9, 983; Control Council Law No. 10 1945, above n 55, art II s (1) (c).

${ }^{507}$ Justice Case, above n 9, 984.
} 
The very essence of the prosecution case is that the laws, the Hitlerian decrees and the Draconic, corrupt, and perverted Nazi judicial system themselves constituted the substance of war crimes and crimes against humanity and that participation in the enactment and enforcement of them amounts to complicity in crime.

Hence, before evaluating the individual guilt of the defendants, Tribunal III looked at the existing German law and its development under the Nazi Government.

(a) Ermaechtigungsgesetz (Enabling Act 1933)

The Weimar Constitution of Germany from 11 August 1919 contained not only generally accepted provisions of international law but also fundamental rights, which were guaranteed to all Germans. ${ }^{508}$ The weak point of the Constitution was Article 48, which provided that the Reich President was empowered to suspend certain fundamental rights either completely or partially, if the safety and order of the German Reich was considerably disturbed or endangered. ${ }^{509}$

Based on this Article, Reich President von Hindenburg and Hitler, the new Reich Chancellor, on 28 February 1933, promulgated a decree that expressly suspended basic rights of the Weimar Constitution and, in addition, provided that the Reich Government might temporarily take over the powers of the highest State authority to restore public security. ${ }^{510}$

A month later, on 24 March 1933, an intimidated Reichstag, the German Federal Parliament, enacted the Gesetz zur Behebung der Not von Volk und Reich (Law concerning the Relief of Distress of the Nation and the Reich), commonly known as Ermaechtigungsgesetz (Enabling Act 1933),

\footnotetext{
${ }^{508}$ Weimar Constitution 1919 (Germany), arts 109 et seq; See also Justice Case, above n 9, 986.

${ }^{509}$ Weimar Constitution 1919, above n 508, art 48; See also Justice Case, above n 9, 986.

${ }^{510}$ Verordnung des Reichspraesidenten zum Schutz von Volk und Staat vom 28. Februar 1933 (Order of the Reich President for the Protection of People and State from 28 February 1933) 17 RGBl 1933 I 83, para 2; See also Justice Case, above n 9, 986-987.
} 
which in fact opened the door for the Nazi Government to overrule the Constitution itself. ${ }^{511}$ It provided that laws decreed by the government may deviate from the constitution, and that laws of the Reich can be enacted by the government apart from the procedures provided by the constitution. ${ }^{512}$

As a result, on 14 July 1933, a law was enacted declaring the NSDAP to be the only political party, and making it a crime to maintain or form any other political party. ${ }^{513}$ Also, on 30 January 1934, the Reichstag passed a law ruling that the sovereign powers of the German States are fully transferred to the Federation. ${ }^{514}$ The provisions of the Enabling Act were reconfirmed by Acts of the Reichstag on 30 January 1937 and on 30 January $1939 .^{515}$

The Tribunal stressed that the Enabling Act 1933 was the starting point of ${ }^{516}$

the legal and judicial process by which the entire judicial system was transformed into a tool for the propagation of the National Socialist ideology, the extermination of opposition thereto, and the advancement of plans for aggressive war and world conquest.

(b) Arbitrariness in criminal law

After the obstacle of the Weimar Constitution was hurdled, the criminal law in particular was changed in many ways to become an

\footnotetext{
511 Justice Case, above n 9, 987.

512 Gesetz zur Behebung der Not von Volk und Reich vom 24. Maerz 1933 (Law concerning the Relief of Distress of the Nation and the Reich from 24 March 1933) 25 RGB1 1933 I 141, arts 1 and 2; See also Justice Case, above n 9, 987.

${ }^{513}$ Gesetz gegen die Neubildung von Parteien vom 14. Juli 1933 (Law against the creation of Political Parties from 14 July 1933) 81 RGB1 1933 I 479, paras 1 and 2; See also Justice Case, above n 9, 987.

514 Gesetz ueber den Neuaufbau des Reichs vom 30. Januar 1934 (Law for the Restructuring of the Reich from 30 January 1934) 11 RGB1 1934 I 75, arts 1 and 2; See also Justice Case, above n 9, 987-988.

515 Justice Case, above n 9, 988.

516 Ibid.
} 
instrument of Nazi politics and ideology. Military Tribunal III described this process as follows: ${ }^{517}$

\begin{abstract}
Beginning in 1933, there developed side by side two processes by which the Ministry of Justice and the courts were equipped for terroristic functions in support of the Nazi regime. By the first, the power of life and death was ever more broadly vested in the courts. By the second, the penal laws were extended in such inconclusive and indefinite terms as to vest in the judges the widest discretion in the choice of law to be applied, and in the construction of the chosen law in any given case.
\end{abstract}

On 4 April 1933, just two months after the Nazis took over government, the death sentence was introduced in German criminal law by the Gesetz zur Abwehr politischer Gewalttaten (Law for the Protection against Violent Political Acts). It authorised the death penalty for a number of crimes, particularly adding that it applies "whenever milder penalties had been prescribed hitherto."

A year later, on 24 April 1934, the definition of high treason was also greatly expanded, and the death sentence was implemented as a possible punishment. ${ }^{519}$

A significant step was the Gesetz zur Aenderung des Strafgesetzbuches (Law Concerning the Alteration of the Penal Code) from 28 June 1935. It abolished the general rule that criminal statutes should be definite and certain, and allowed judges to sentence following a similar law if no specific law could be applied directly. ${ }^{520}$

The transformation of the law continued: On 17 August 1938, the death sentence was authorised and made mandatory to the crime of undermining German military efficiency; ${ }^{521}$ in 1939 , different ordinances

\footnotetext{
517 Ibid.

${ }^{518}$ Gesetz zur Abwehr politischer Gewalttaten vom 4. April 1933 (Law for the Protection against Violent Political Acts from 4 April 1933) 31 RGBl 1933 I 162, para 1; See also Justice Case, above n 9, 988.

${ }^{519}$ Gesetz zur Aenderung von Vorschriften des Strafrechts und des Strafverfahrens vom 24. April 1934 (Law for the amendment of the Provisions of Criminal Law and Procedure from 24 April 1934) 47 RGB1 1934 I 341, para 83; See also Justice Case, above n 9, 988-989.

${ }^{520}$ Gesetz zur Aenderung des Strafgesetzbuches vom 28. Juni 1935 (Law Concerning the Alteration of the Penal Code from 28 June 1935), above n 428, art 2.

${ }^{521}$ Justice Case, above n 9, 991.
} 
and decrees like the Feindsenderverordnung (Decree to Stop Deliberate Listening to Foreign Stations) and the Verordnung gegen Volksschaedlinge (Decree against Public Enemies) were enacted, implementing new crimes that could be punished by death; ${ }^{.52}$ on 5 December 1939 , the death penalty was extended to various crimes of violence, even when those were committed before the decree became valid what, in fact, was the abolishment of the ex post facto principle, ${ }^{523}$ and on 4 September 1941, the death penalty was also provided for dangerous habitual criminals and sex criminals. $^{524}$

However, the transformation of the German law system into an instrument of the Nazi Party culminated on 20 August 1942, when Hitler issued a decree to establish a strong National Socialist Administration of Justice, if necessary in deviation from any existing law. ${ }^{525}$ Finally, on 5 May 1944, influenced by the heavy German war defeats, came the quasisuspension of all legal restrictions for judges as to the degree of penalty. ${ }^{526}$

At this point, law and justice had been replaced by judicial arbitrariness. Tribunal III summarised as follows: ${ }^{527}$

\footnotetext{
The statutes which we have reviewed were merely steps in the process of increased severity of the criminal law and in the development of a loose concept concerning the definition of crime. ... [The decree of 20 August 1942] was especially evident in the statutes concerning the 'sound sentiment of the people', crime by analogy, and undermining the military efficiency of the nation. In place of the control of law there was substituted the control of National Socialist ideology as a guide to judicial action.
}

\footnotetext{
${ }^{522}$ Ibid, 991-992.

${ }^{523}$ Ibid, 992.

${ }^{524}$ Ibid.

${ }^{525}$ Ibid, 993.

${ }^{526}$ Ibid, 992-993.

${ }^{527}$ Ibid, 993.
} 
(c) Discrimination against minorities

On 7 April 1933, a law of the Reich Government provided that Communists and people of non-Aryan descent, which in the eyes of National Socialist ideology were mainly Jews, may be refused permission to practice law. ${ }^{528}$ The Gesetz zum Schutze des deutschen Blutes und der deutschen Ehre (Law for the Protection of German Blood and German Honour) from 15 September 1935, also known as the infamous Nuremberg Laws, prohibited marriages and sexual intercourse between Jews and Aryans. ${ }^{529}$ These laws were the starting point of legislation that almost completely expelled Jews from public service and public life. ${ }^{530}$

On 4 December 1941, the Verordnung ueber die Strafrechtspflege gegen Polen und Juden in den eingegliederten Ostgebieten (Decree concerning the Organisation and Criminal Jurisdiction against Poles and Jews in the Incorporated Eastern Territories) came into effect. ${ }^{531}$ It provided special regulations for allegedly criminal acts committed by Jews or Poles, for example: "The death penalty, or in less serious cases imprisonment, shall be imposed on any Jew or Pole ... [i]f he urges or incites to disobedience to any decree or regulation issued by the German authorities."

In the view of Tribunal III, this decree "marks perhaps the extreme limit to which the Nazi Government carried its statutory and decretal persecution of racial and religious minorities. ${ }^{, 533}$ However, the decree was only the climax of the establishment of injustice within the German judiciary.

\footnotetext{
${ }^{528}$ See generally Gesetz ueber die Zulassung zur Rechtsanwaltschaft vom 7. April 1933 (Law concerning the Admission to the Legal Profession from 7 April 1933) 36 RGB1 1933 I 188; See also Justice Case, above n 9, 993-994.

${ }^{529}$ Gesetz zum Schutze des deutschen Blutes und der deutschen Ehre vom 15. September 1935 (Law for the Protection of German Blood and German Honour from 15 September 1935) 100 RGB1 1935 I 1146; See also Justice Case, above n 9, 994.

${ }^{530}$ Justice Case, above n 9, 994.

${ }^{531}$ Ibid, 995-996.

${ }^{532}$ Ibid, 996.

${ }^{533}$ Ibid, 995.
} 
On 1 July 1943, the 13. Verordnung zum Reichsbuergergesetz $\left(13^{\text {th }}\right.$ Regulation under the Reich Citizenship Law) was issued, which provided that allegedly criminal actions of Jews were to be punished directly by the police without any indictment and proceeding. ${ }^{534}$

This was the final step of depriving the Jews of their human rights and almost completely outlawing them in everyday life.

(d) Expansion of the German law on occupied territories

Besides the special regulations for allegedly criminal acts of Jews and Poles, the decree from 4 December 1941 also introduced another important element to the Nazi judiciary, which Tribunal III described as "the extension of German laws to occupied territory, to purportedly annexed territory, and to territory of the so-called protectorates."

In March and September 1938 and in March 1939, already before the start of World War II, the German Army had invaded Austria and parts of Czechoslovakia (the Sudetenland and Bohemia and Moravia) and had incorporated them into the German Reich. ${ }^{536}$ During World War II, also all or portions of Poland, Denmark, Norway, Belgium, the Netherlands, Luxembourg, Yugoslavia, Greece and Russia were occupied and annexed to the German Reich. ${ }^{537}$

The German criminal law had always been applicable to German nationals but, beginning in April 1939, different statutes extended the draconic and discriminatory German laws, which had been put into force in

\footnotetext{
${ }^{534}$ Ibid, 996-997.

535 Ibid, 995.

${ }^{536}$ Ibid, 997-998.

${ }^{537}$ Ibid, 998.
} 
the old Reich, to the occupied territories. ${ }^{538}$ For example, on 14 April 1939, an act provided that ${ }^{539}$

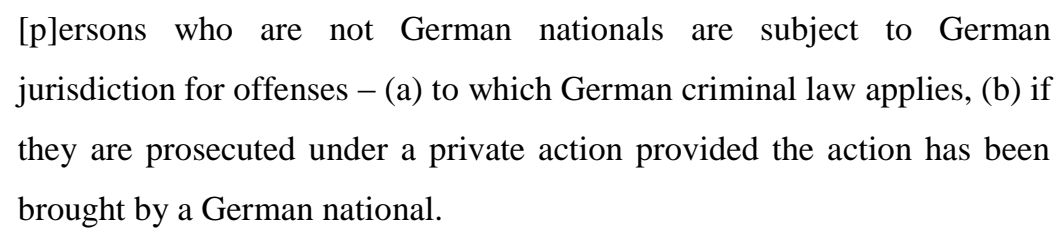

Since 5 September 1939, the Verordnung gegen Volksschaedlinge (Decree against Public Enemies) was made "applicable in the Protectorate of Bohemia and Moravia and also for those persons who are not German citizens" ${ }^{540}$; and on 25 November 1939, another Verordnung gegen Wehrmittelbeschaedigung (Decree against Damage to War Materials) was explicitly made applicable also to non-Germans of the Protectorate Bohemia and Moravia. ${ }^{541}$

On 6 May 1940, the Verordnung ueber den Geltungsbereich des Strafrechts (Decree on the Extension of the Application of Criminal Law) made German criminal law applicable to crimes which were committed by foreigners abroad; ${ }^{542}$ and on 25 November 1941, the Verordnung ueber die Beschlagnahme juedischen Vermoegens (Decree concerning the Confiscation of Jewish Property) was made applicable in the Protectorate of Bohemia and Moravia and the incorporated Eastern territories. ${ }^{543}$

(e) Courts and the law of procedure

Similar to the substantive law, the Nazis also extended the law of procedure and the German court system.

\footnotetext{
${ }^{538}$ Ibid.

${ }^{539}$ Ibid.

${ }^{540}$ Ibid.

541 Ibid.

${ }^{542}$ Ibid, 998-999.

${ }^{543}$ Ibid, 999.
} 
Besides the newly created People's Court and the Special Courts, whose jurisdictions were rapidly extended, ${ }^{544}$ the Nazis also erected courts martial, Police courts and SS courts. Contrarily to the traditional civil courts, which struggled with their loss of jurisdiction in many areas, these courts did not really deserve to be called courts at any time.

Good examples are the courts martial, which were erected in the occupied Eastern territories to apply the provisions of the Decree against Poles and Jews from 4 December 1941. Article XIII section (2) of the decree provided the death sentence as the only punishment imposed by these courts, which resulted in proceedings that often consisted of nothing else but the delivery of a judgment. ${ }^{545}$

Changes within the law of procedure began with the centralisation of the clemency powers to the President of the Reich on 16 February $1934 .^{546}$ However, only a decree promulgated by Hitler on 21 March 1942, regarding the simplification of the administration of justice, brought fundamental changes to the procedure. ${ }^{547}$

To realise the provisions of this statute, subsequent decrees were issued by the responsible Ministers of Justice Schlegelberger (on 13 August 1942) and Thierack (on 15 February 1945), limiting the participation of lawyers in criminal proceedings and expanding the jurisdictions of courts martial. $^{548}$

In the view of Tribunal III, this did not only make it easy to punish alleged criminals, but it also ensured that "the will of Hitler became a dominating force in the Ministry of Justice and in the courts."

\footnotetext{
${ }^{544}$ See Part III C 1 (b) (ii) Members of the National Socialist People's Court and Part III C 1 (b) (iii) Members of National Socialist Special Courts.

545 Justice Case, above n 9, 1009.

546 Ibid, 1007.

${ }^{547}$ Ibid, 1008.

${ }^{548}$ Ibid, 1008-1009.

${ }^{549}$ Ibid, 1007.
} 
(f) The execution of the law in Nazi Germany

The law in action in Nazi Germany was primarily based on the so called Fuehrer Principle, which seriously affected officials of the Ministry of Justice, prosecutors and judges. ${ }^{550}$ Tribunal III stated: ${ }^{551}$

Two basic principles controlled conduct within the Ministry of Justice. The first concerned the absolute power of Hitler in person or by delegated authority to enact, enforce, and adjudicate law. The second concerned the incontestability of such law.

This evaluation was based on the testimony of a witness for all of the defendants, Professor Hermann Jahrreiss, who had stated that "restrictions under German law did not exist for Hitler. He was legibus solutus in the same meaning in which Louis XIV claimed that for himself in France."

(i) Hitler as supreme judge

Hitler was not only the supreme legislator but also the supreme judge of Nazi Germany. ${ }^{553}$ In an address to the Reichstag on 26 April 1942, Hitler had declared: ${ }^{554}$

I do expect one thing: That the nation gives me the right to intervene immediately and to take action myself wherever a person has failed to render unqualified obedience. ... I therefore ask the German Reichstag to confirm expressly that I have the legal right to keep everybody to his duty and to cashier or remove from office or position without regard for his person, or his established rights, whoever, in my view and according to my considered opinion, has failed to do his duty. ... From now on, I shall

\footnotetext{
${ }^{550}$ Ibid, 1010; See also Part IV A 3 Individual liability.

${ }^{551}$ Justice Case, above n 9, 1010-1011.

552 Ibid, 1011.

${ }^{553}$ See Part IV A 3 Individual liability.

${ }^{554}$ Justice Case, above n 9, 1011-1012.
} 
intervene in these cases and remove from office those judges who evidently do not understand the demand of the hour.

On the same day, the Reichstag had resolved: ${ }^{555}$

... the Fuehrer must have all the rights postulated by him which serve to further or achieve victory. Therefore - without being bound by existing legal restrictions - in his capacity as leader of the nation, Supreme Commander of the Armed Forces, governmental chief and supreme executive chief, as supreme justice, and leader of the Party - the Fuehrer must be in a position to force with all means at his disposal every German, if necessary, whether he be common soldier or officer, low or high official or judge, leading or subordinate official of the Party, worker or employee, to fulfil his duties. In case of violation of these duties, the Fuehrer is entitled after conscientious examination, regardless of so-called well-deserved rights, to mete out due punishment, and to remove the offender from his post, rank and position, without introducing prescribed procedures.

With this clear manifestation of Hitler's will and of the Nazi ideology as the only valid German law, it is quite surprising that the reaction among the leading German jurists was not some kind of opposition or resignation from their positions in reaction to the limitation of their power and independence, but instead massive support of this new principles. The defendant Rothenberger, for example, once stated: ${ }^{556}$

Here is a man [Hitler] who in his position represents the ideal of the judge in its perfect sense, and the German people elected him for their judge first of all, of course, as 'judge' over their fate in general, but also as 'supreme magistrate and judge'.

And at another place, in 1943, Rothenberger summarised his legal philosophy as follows: "The judge is on principle bound by the law. The laws are the orders of the Fuehrer." 557

Rothenberger shared this view with his co-defendant Schlegelberger, who had expressed his opinion already on 10 March 1936: "It should be

\footnotetext{
555 Beschluss des Grossdeutschen Reichstags vom 26. April 1942 (Resolution of the GreatGerman Reichstag from 26 April 1942); See also Justice Case, above n 9, 1012.

${ }_{556}$ Justice Case, above n 9, 1012.

${ }^{557}$ Ibid, 1014.
} 
emphasised, however, that in the sphere of the law, also, it is the Fuehrer and he alone who sets the pace of development." defendants were flanked by Minister of Justice Thierack, who had said on 5 January 1943: "So also with us the conviction has grown in these 10 years in which the Fuehrer has led the German people that the Fuehrer is the chief justice and the supreme judge of the German people." 559

As a result, it can be said that Hitler not only acted like the supreme judge of Nazi Germany, but was also seen and accepted as such by Germany's judiciary.

(ii) Execution of Hitler's will

The concrete execution of the Fuehrer Principle within the German judicature was realised by the so called Richterbriefe (Judges' Letters), which were issued by the Reich Minister of Justice and systematically distributed to all German judges. 560

The letters were made as instructions for judges as how to decide certain cases by discussing particular decisions, which had been filed in various courts and had failed to be in line with National Socialist ideology. ${ }^{561}$ The first of these letters was issued on 1 October 1942 and reminded the judges "that Hitler was the supreme judge and that 'leadership and judgeship have related characters." "562

Soon after the first Judges' Letters were distributed, Minister of Justice Thierack also started issuing so called Anwaltsbriefe (Lawyers' Letters). ${ }^{563}$ In the view of Military Tribunal III, those were made primarily to warn the defence counsels "that they avoid any criticism of National

\footnotetext{
${ }^{558}$ Ibid, 1013.

${ }^{559}$ Ibid.

${ }^{560}$ Ibid, 1017.

561 Ibid.

562 Ibid.

${ }^{563}$ Ibid, 1019.
} 
Socialist justice and refrain from too much ardor in the defense of persons charged with political crimes."

All these actions pursued only one goal: to manipulate the German judges in their decisions in favour of National Socialist ideology. However, it was no guarantee. Therefore, Hitler and his top-ranking associates often interfered in the finding of individual criminal sentences and objected to many judgments themselves, until they were revised into a decision convenient to Hitler's opinion. ${ }^{565}$

Among many others, one example is the case of the Jew Markus Luftgas, who was originally sentenced to two and a half years imprisonment for hoarding eggs. ${ }^{566}$ After an objection from Hitler, the State Secretary and Chief of the Reich Chancellery, Hans-Heinrich Lammers, wrote to Schlegelberger on 25 October 1941: "The Fuehrer wishes that Luftgas be sentenced to death." 567 Schlegelberger replied on 29 October 1941: "I have handed over to the Gestapo for the purpose of execution the Jew Markus Luftgas who had been sentenced to $2 \frac{1}{2}$ years of imprisonment."

Additionally, Hitler also delegated this direct exertion of influence to the Reich Minister of Justice. In defiance of all principles of an independent judiciary, he explicitly authorised him "to deviate from any existing law" in August 1942. ${ }^{569}$

\footnotetext{
564 Ibid.

${ }^{565}$ Ibid, 1014.

${ }^{566}$ Ibid, 1016.

${ }^{567}$ Ibid, 1016-1017.

${ }^{568}$ Ibid, 1017.

569 Ibid.
} 


\section{(iii) Outcome}

From a substantive law point of view, all changes illustrated in this chapter finally resulted in the replacement of the old principle "no penalty without a law" by a new principle "no crime without punishment"

This new philosophy in Nazi Germany's jurisdiction was specifically made clear by the infamous Reich Minister of Propaganda Joseph Goebbels, who addressed the members of the People's Court in a speech on 22 July $1942:^{571}$

\footnotetext{
While making his decisions the judge had to proceed less from the law than from the basic idea that the offender was to be eliminated from the community. During a war it was not so much a matter of whether a judgment was just or unjust but only whether the decision was expedient. The State must ward off its internal foes in the most efficient way and wipe them out entirely.
}

Altogether, Tribunal III concluded that the described occurrences, in fact, led to the "utter destruction of judicial independence and impartiality" $" 572$. It further pointed out: "The function of the Nazi courts was judicial only in a limited sense. They more closely resembled administrative tribunals acting under directives from above in a quasi-judicial manner."573

However, the Tribunal also stated that the Nazi law system divided the judges in two categories: ${ }^{574}$

In the first we find the judges who still retained ideals of judicial independence and who administered justice with a measure of impartiality and moderation. Judgments which they rendered were set aside by the employment of the nullity plea and the extraordinary objection. The defendants they sentenced were frequently transferred to the Gestapo on

\footnotetext{
${ }^{570}$ Ibid, 1022.

${ }^{571}$ Ibid, 1021-1022.

572 Ibid, 1024.

${ }^{573}$ Ibid, 1024-1025.

${ }^{574}$ Ibid, 1025.
} 
completion of prison terms and were then shot or sent to concentration camps. The judges themselves were threatened and criticized and sometimes removed from office. In the other category were the judges who with fanatical zeal enforced the will of the Party with such severity that they experienced no difficulties and little interference from party officials.

A prominent example for the few German judges who belonged to the first category was Lothar Kreyssig, a judge at the Brandenburg County Court. ${ }^{575} \mathrm{He}$ had formally protested the secret killings of handicapped and the detentions in concentration camps by sending letters of complaints to the President of the Prussian Supreme Court ${ }^{576}$ he had issued injunctions against the Nazi programme of killing mentally handicapped persons $;{ }^{577}$ and he had brought charges against one of its administrators. ${ }^{578}$

In 1940, he was forced to retire early and a criminal investigation against him took place. ${ }^{579}$ However, after the investigation was closed in 1942 , he was left in peace by the Nazi authorities. ${ }^{580}$

Although this case may not be valid as a guarantee that every judge had the opportunity to resist without fearing life or health threatening consequences, ${ }^{581}$ it confirms the Tribunal's view that, although the whole law system in Nazi Germany was transformed into an instrument of National Socialist policy, the individual judge himself had still been able to adhere to moral and ethical values and to resist to become an accomplice of the Nazis, at least until removed from office.

Yet, the Tribunal realised that in such a case the removal from office was only a matter of time and, therefore, declined the suggestion that the

\footnotetext{
575 Mueller, above n 120, 193.

576 "Nuremberg Trials 60 ${ }^{\text {th }}$ Anniversary: Justice Case" www.adl.org (last accessed 18 March 2010); Mueller, above n 120, 193-196.

577 Ibid.

578 Ibid.

${ }^{579}$ Mueller, above n 120, 195.

580 Ibid.

${ }^{581}$ It has to be noted here that, as a matter of fact, no judge or prosecutor who served under the Nazi Government was physically harmed for any politically unpopular decisions. Nevertheless, it has to be taken into account that during the Nazi regime nobody could be sure about it. Kramer Plaedoyer fuer ein Forum zur juristischen Zeitgeschichte, above n 189, 15.
} 
defendants who had been working as judges could be entitled to benefit from the Anglo-American doctrine of judicial immunity. The Tribunal argued reasonably as follows: $:^{582}$

The doctrine that judges are not personally liable for their judicial actions is based on the concept of an independent judiciary administering impartial justice. Furthermore, it has never prevented the prosecution of a judge for malfeasance in office. If the evidence sited supra does not demonstrate the utter destruction of judicial independence and impartiality, then we 'never writ nor no man ever proved'.

\section{The Tribunal's evaluation of the legality of Nazi laws}

No doubt, the rigorous laws and court decisions in Nazi Germany were immoral and generally did not really deserve to be called lawful, but the judges of Tribunal III tried to free their minds completely from such conclusions, and evaluated these laws and decisions from a purely legal point of view. In the judgment, they stated: ${ }^{583}$

The Tribunal is keenly aware of the danger of incorporating in the judgment as law its own moral convictions or even those of the AngloAmerican legal world. This we will not do. We may and do condemn the Draconic laws and express abhorrence at the limitations imposed by the Nazi regime upon freedom of speech and action, but the question still remains unanswered: 'Do these Draconic laws or the decisions rendered under them constitute war crimes or crimes against humanity?'

To find an answer, the Tribunal concentrated on cases in which the death penalty had been imposed by German courts. ${ }^{584}$

${ }^{582}$ Justice Case, above n 9, 1024.

${ }^{583}$ Ibid, 1025-1026.

${ }^{584}$ Ibid, 1025. 
(a) Habitual criminals

Based on the penal code, German courts sentenced habitual criminals to death in many cases during World War II. Tribunal III compared this fact to a likely situation in other countries, including the United States, and concluded that the imposed death penalties by German courts in such cases could not be classified as a crime against humanity. ${ }^{585}$

The Tribunal argued as follows: $:^{586}$

In many civilized states statutory provisions require the courts to impose sentences of life imprisonment upon proof of conviction of three or more felonies. We are unable to say in one breath that life imprisonment for habitual criminals is a salutary and reasonable punishment in America in peace times, but that the imposition of the death penalty was a crime against humanity in Germany when the nation was in the throes of war.

\section{(b) Plunder in German territory}

Similar to the treatment of habitual criminals, the penal code of Nazi Germany provided the death penalty also for plunderers. Especially during the war, German courts had often imposed this hardest possible punishment on persons who had looted in the ruined German cities after Allied air raids.

Military Tribunal III evaluated these codes and sentences as necessary in the specific situation of Germany during the war. ${ }^{587}$ It stated: ${ }^{588}$

Anyone who has seen the utter devastation of the great cities of Germany must realize that the safety of the civilian population demanded that the

\footnotetext{
${ }^{585}$ Ibid, 1026.

586 Ibid.

587 Ibid.

588 Ibid.
} 
werewolfes who roamed the streets of the burning cities, robbing the dead, and plundering the ruined homes should be severely punished.

As a result, the Tribunal concluded that the imposed death sentences by the judiciary in cases of plundering did not constitute crimes against humanity. ${ }^{589}$

(c) Crimes against the wartime economy

Tribunal III evaluated cases in which German courts had sentenced people to death for hoarding or for violating war economy decrees similarly to cases of plundering. The Tribunal's view was that the threat and enforcement of capital punishment was required to secure the chances of individual survival of the civilian population during times of war, when all kind of goods, especially food, were rare and of high value. ${ }^{590}$

The Tribunal's argument was simple but understandable: "Every nation recognizes the absolute necessity of more stringent enforcement of the criminal law in times of great emergency." 591

Hence, in the view of Tribunal III, the imposition of the death penalty by German courts in cases of crimes against the wartime economy had been not necessarily a crime against humanity. ${ }^{592}$

(d) Undermining military efficiency

The death sentences by German courts in cases of undermining military efficiency were analysed with great care by Tribunal III. Defendants in such cases were mostly tried for violating the limitations on

\footnotetext{
${ }^{589}$ Ibid.

590 Ibid.

591 Ibid.

592 Ibid.
} 
freedom of speech, which were imposed by the Nazi laws to protect the military aims of Nazi Germany during World War II. ${ }^{593}$

After stressing that these limitations are generally revolting "to our sense of justice" ${ }^{, 594}$, the Tribunal said: ${ }^{595}$

\begin{abstract}
A court would have no hesitation in condemning them under any free constitution, including that of the Weimar republic, if the limitations were applied in time of peace; but even under the protection of the Constitution of the United States a citizen is not wholly free to attack the Government or to interfere with its military aims in time of war. In the face of a real and present danger, freedom of speech may be somewhat restricted even in America. Can we then say that in the throes of total war and in the presence of impending disaster those officials who enforced these savage laws in a last desperate effort to stave off defeat were guilty of crimes against humanity?
\end{abstract}

The Tribunal, further, argued that the fact that Germany was waging a criminal war of aggression could not have any impact on the Justice Trial, because the defendants here were not charged with crimes against peace, nor has it been proven that they were part of a criminal conspiracy to plan the war, nor was the start of the war per se a violation of international law. ${ }^{596}$

Also, in the view of the Tribunal, the actions of the German judiciary during the war could not all be seen as illegal just because it was a criminal war of aggression, otherwise "every soldier who marched under orders into occupied territory or who fought in the homeland was a criminal and a murderer." 597

Thus, Tribunal III concluded that "the domestic laws and judgments in Germany which limited free speech in the emergency of war cannot be condemned as crimes against humanity" ${ }^{\circ 98}$. The imposed death sentences, therefore, although often given arbitrarily and in a discriminatory manner,

\footnotetext{
593 Ibid.

594 Ibid.

595 Ibid.

596 Ibid.

${ }^{597}$ Ibid, 1027.

598 Ibid.
} 
were principally not illegal under the existing circumstances in Germany during World War II. ${ }^{599}$

(e) Treason and High Treason

Generally, the crimes of treason and high treason exist in the penal code of almost every nation. To punish offenders with the death penalty was also not totally unusual in many countries of the civilised Western world at the time. Nevertheless, Tribunal III made a big difference in its analysis of those death sentences, which had been imposed on Poles who were charged with high treason against the German Reich.

In many cases, Poles had been charged with high treason for the only reason that they attempted to escape from the Reich territory. ${ }^{600}$ They were indicted for "attempting, by violence or threat of violence, to detach from the Reich territory belonging to the Reich, contrary to the express provisions of section 80 of the law of 24 April 1934." ${ }^{, 61}$ The so called territory in these cases consisted of portions of Poland which the German Reich had illegally annexed after the outbreak of World War II. ${ }^{602}$

In the Tribunal's view, this would have meant that "every Polish soldier from the occupied territories fighting for the restoration to Poland of territory belonging to it would be guilty of high treason against the Reich" ${ }^{\text {,03 }}$. Hence, Tribunal III evaluated these cases and the underlying laws

\footnotetext{
${ }^{599}$ Ibid, 1026-1027.

${ }^{600}$ Ibid, 1028.

601 Ibid; See also Gesetz zur Aenderung von Vorschriften des Strafrechts und des Strafverfahrens vom 24. April 1934 (Law for the amendment of the Provisions of Criminal Law and Procedure from 24 April 1934), above n 519, para 80.

${ }^{602}$ Justice Case, above n 9, 1027-1028; US Military Tribunal III had stated before: "Sir Arnold D. McNair expressed a principle which we believe to be incontestable in the following words: 'A purported incorporation of occupied territory by a military occupant into his own kingdom during the war is illegal and ought not to receive any recognition."' Justice Case, above n 9, 1028.

${ }^{603}$ Ibid, 1028.
} 
as an "unwarrantable extension of the concept of high treason, which constituted ... a war crime and a crime against humanity."

(f) The Nacht und Nebel Erlass (Night and Fog Decree)

The Night and Fog Decree was basically a personal order of Hitler from 7 December 1941, which provided as follows: ${ }^{605}$

(a) that criminal acts committed by non-German civilians directed against the Reich or occupation forces endangering their safety or striking power should require the application of the death penalty in principle;

(b) that such criminal acts would be tried in occupied territories only when it appeared probable that the death sentence would be passed and carried out without delay. Otherwise the offenders would be taken to Germany;

(c) that offenders taken to Germany were subject to court martial procedures there only when a particular military concern should require it;

(d) that the Commander-in-Chief in occupied territories and certain subordinates within their command would be held personally responsible for the execution of this decree;

(e) that the Chief of the OKW $\left.{ }^{606}\right]$ would decide in which of the occupied territories this decree would be applied.

The order received its name because, under it, people were taken away from their homes, often by night, and disappeared "forever into the fog of the unknown."

\footnotetext{
${ }^{604}$ Ibid.

${ }^{605}$ United Nations War Crimes Commission, above n 223, 8-9.

${ }^{606} \mathrm{OKW}$ was the abbreviation for Oberkommando der Wehrmacht (High Command of the German Armed Forces). Its head was German field marshal Wilhelm Keitel, who was sentenced to death by the International Military Tribunal at Nuremberg. "Wilhelm Keitel" www.britannica.com (last accessed 18 March 2010).

${ }^{607}$ Whitney R Harris, above n 18, 220.
} 
The decree was executed by the Ministry of Justice in cooperation with the OKW and the Gestapo. ${ }^{608}$ Its aim was to discourage the population of occupied territories from military and political resistance. ${ }^{609}$ After having analysed the huge amount of exhibits, Tribunal III described the workings of the programme as follows: $:^{610}$

\begin{abstract}
... civilians of occupied countries accused of alleged crimes in resistance activities against German occupying forces were spirited away for secret trial by special courts of the Ministry of Justice within the Reich; that the victim's whereabouts, trial, and subsequent disposition were kept completely secret, thus serving the dual purpose of terrorizing the victim's relatives and associates and barring recourse to evidence, witnesses, or counsel for defense. If the accused was acquitted, or if convicted, after serving his sentence, he was handed over to the Gestapo for 'protective custody' for the duration of the war. These proceedings resulted in the torture, ill treatment, and murder of thousands of persons.
\end{abstract}

The Tribunal, further, emphasised that the existence of concentration camps was extensively used as a tool to terrorize the people in occupied territories. $^{611}$ It referred to the judgment of the International Military Tribunal, which had described in detail the manner of operation of concentration camps and the appalling cruelties and horrors therein, ${ }^{612}$ and stated: "Such concentration camps were used extensively for the NN prisoners in the execution of the Night and Fog decree ..."613.

The prosecution charged all of the defendants in the Justice Trial with participation in the execution and carrying out of the Night and Fog Decree. ${ }^{614}$ Thus, Tribunal III spent a lot of its time discussing and analysing this issue. ${ }^{615}$ In the end, it concluded: ${ }^{616}$

\footnotetext{
608 Justice Case, above n 9, 1031.

${ }^{609}$ Kastner "Der Dolch des Moerders war unter der Robe des Juristen verborgen: Der Nuernberger Juristen-Prozess 1947”, above n 317, 701.

${ }^{610}$ Justice Case, above n 9, 1031-1032.

${ }^{611}$ Ibid, 1033.

${ }^{612}$ Ibid; See also International Military Tribunal I, 234 et seq.

${ }^{613}$ Justice Case, above n 9, 1033; NN is used as an abbreviation by Tribunal III throughout the judgment and refers to the Night and Fog Plan.

${ }^{614}$ Ibid, 1032.

${ }^{615}$ See generally Ibid, 1031-1062.

${ }^{616}$ Ibid, 1057.
} 
The enforcement of the directives under the Hitler NN plan or scheme became a means of instrumentality by which the most complete control and coercion of a lot of the people of occupied territories were affected and under which thousands of the civilian population of occupied areas were imprisoned, terrorized, and murdered. The enforcement and administration of the NN directives resulted in the commission of war crimes and crimes against humanity in violation of the international law of war and international common law relating to recognized human rights, and of article II, paragraph 1(b) and (c) of Control Council Law No. 10.

\section{(g) Racial persecution}

One of the major issues in all Nuremberg Trials, and one of the most shocking insights about Nazi Germany after World War II, was the treatment of Poles and Jews by the Nazi Government. ${ }^{617}$

Based on Hitler's rabid anti-Semitism, the Nazi movement had developed racial theories, which declared the supremacy of the Nordic German race and, at the same time, denounced especially Jews as inferior people. ${ }^{618}$ Accordingly, the official programme of the Nazi Party from 24 February 1920 read as follows: ${ }^{619}$

Only a member of the race can be a citizen. A member of the race can only be one who is of German blood without consideration of confession. Consequently, no Jew can be a member of the race.

After the Nazis had taken over power, the Nazi racism ideology became official policy in Germany. ${ }^{620}$ In different procedures before and during World War II, Jews were persecuted within and outside the German Reich.

The so called solution of the Jewish problem was carried out in three steps: (1) the elimination of the Jews from the political and economic life of

${ }^{617}$ See Part V A 1 (c) Discrimination against minorities.

${ }^{618}$ Justice Case, above n 9, 1064; Whitney R Harris, above n 18, 281.

${ }^{619}$ Whitney R Harris, above n 18, 290.

${ }^{620}$ Justice Case, above n 9, 1063; Whitney R Harris, above n 18, 281-282. 
Germany; (2) the enforced deportation and isolation in ghettos all over Europe; and (3) the so called final solution, which was the Nazi term for the extermination of the Jews through slave labour and mass murder, today known as the Holocaust. ${ }^{621}$

The defendants in the Justice Trial were charged with participating ${ }^{622}$ in carrying out a governmental plan and program for the persecution and extermination of Jews and Poles, a plan which transcended territorial boundaries as well as the bounds of human decency. Some of the defendants took part in the enactment of laws and decrees the purpose of which was the extermination of the Poles and Jews in Germany and throughout Europe. Others, in executive positions, actively participated in the enforcement of those laws and in atrocities, illegal even under German law, in furtherance of the declared national purpose. Others, as judges, distorted and then applied the laws and decrees against Poles and Jews as such in disregard of every principle of judicial behaviour.

Tribunal III analysed the given evidence and affirmed that the programme was actually made for the extermination of Jews and Poles, but that "lesser forms of racial persecution were universally practiced by governmental authority and constituted an integral part in the general policy of the Reich." 623

The Tribunal referred to Nazi laws and decrees by which (1) Jews were excluded from the legal profession; (2) intermarriages between Jews and persons of German blood were prohibited; (3) Jews were almost completely expelled from public service, from educational institutions and from many business enterprises; and (4) upon the death of a Jew his property was confiscated without any compensation. ${ }^{624}$

Also, it described the role of the German courts, which had punished sexual intercourse between Jews and German nationals with extreme severity, had rigorously enforced the Decree against Poles and Jews from 4

\footnotetext{
${ }^{621}$ Whitney R Harris, above n 18, 282-283.

${ }^{622}$ Justice Case, above n 9, 1063.

${ }^{623}$ Ibid.

${ }^{624}$ Ibid, 1063-1064; Kastner "Der Dolch des Moerders war unter der Robe des Juristen verborgen: Der Nuernberger Juristen-Prozess 1947”, above n 317, 701; See generally also Whitney R Harris, above n 18, 290-291.
} 
December 1941, had imposed different types of punishment for Poles and Jews from those imposed upon Germans for the same crimes, had severely circumscribed their rights as defendants and had imposed death sentences on Poles and Jews even when such punishment was not prescribed by law. ${ }^{625}$

Last, the Tribunal mentioned the $13^{\text {th }}$ Regulation under the Reich Citizenship Law, under which allegedly criminal acts committed by Jews were to be punished directly by the police without any employment of judicial process. ${ }^{626}$

In the end, Tribunal III concluded: ${ }^{627}$

While the part played by the Ministry of Justice in the extermination of Poles and Jews was small compared to the mass extermination of millions by the SS and Gestapo in concentration camps, nevertheless the courts contributed greatly to the 'final solution' of the problem. ... The evidence conclusively establishes the adoption and application of systematic government-organized and approved procedures amounting to atrocities and offenses of the kind made punishable by C. C. Law 10 and committed against 'populations' and amounting to persecution on racial grounds. These procedures when carried out in occupied territory constituted war crimes and crimes against humanity. When enforced in the Alt Reich against German nationals they constituted crimes against humanity.

\section{Conclusion}

With evidence based mainly on German records, the Tribunal was able to analyse and evaluate the existing law and the legal practice in Nazi Germany in a thorough manner. It drew the correct conclusion that many laws enacted by the Nazi Government and the execution of law within the Third Reich did not deserve to be called law at all and were, in fact, crimes against humanity.

${ }^{625}$ Justice Case, above n 9, 1063-1064.

${ }^{626}$ Ibid, 1064.

${ }^{627}$ Ibid, 1081. 
At this, the documentary evidence speaks for itself as the democratic principle of an independent judicature was in fact abolished, and court proceedings did exist only as a leftover of democratic times without any meaning for the final judgment.

The analysis of the Tribunal in relation to this issue, bears no signs of victor's justice. The chances of exercising such had been, in fact, very small because the Nazi laws and decrees as well as the many captured German documents drew a very accurate picture of the barbarity and inhumanity, which usurped the German law after the Nazis took over power. However, the objectivity of the Tribunal becomes clear by the fact that not all laws and actions of the German judiciary were evaluated unlawful, for example, the infliction of the death penalty in certain cases of habitual crimes and plunder during the war.

Overall, it is remarkable how carefully Tribunal III looked at the details of the Nazi legal system, obviously to get a better understanding of the individual situation of the defendants under the Nazi regime.

\section{B Individual Verdicts and Sentences}

The question whether the defendants were individually guilty fuelled a ferocious debate throughout the Justice Trial. Based on the argument that they did not have much choice but to follow Hitler's superior orders, it was widely controversial in public and among legal experts whether the 16 defendants could be held responsible for the atrocities committed in the name of law in Nazi Germany and its occupied territories. ${ }^{628}$

Military Tribunal III stated: ${ }^{629}$

No defendant is specifically charged in the indictment with the murder or abuse of any particular person. If he were, the indictment would, no

\footnotetext{
${ }^{628}$ See Part IV A 3 Individual liability.
}

${ }^{629}$ Justice Case, above n 9, 984-985. 
doubt, name the alleged victim. Simple murder and isolated instances of atrocities do not constitute the gravamen of the charge. Defendants are charged with crimes of such immensity that mere specific instances of criminality appear insignificant by comparison. The charge, in brief, is that of conscious participation in a nation wide government-organized system of cruelty and injustice, in violation of the laws of war and of humanity, and perpetrated in the name of law by the authority of the Ministry of Justice, and through the instrumentality of courts. The dagger of the assassin was concealed beneath the robe of the jurist.

To prove or rebut this accusation, the Tribunal had to undertake an intense look at the personal and professional story of each individual defendant under the Nazi regime.

The evidence against the defendants was primarily based on captured German documents, but also on testimonies of witnesses and statements of the defendants themselves. ${ }^{630}$ In his Final Report, Chief Prosecutor Telford Taylor stated: ${ }^{631}$

Few of the defendants committed atrocities with their own hands, and in fact they were rarely visible at or within many miles of the scenes of their worst crimes. They made plans and transmitted orders, and the most compelling witnesses against them were the documents which they drafted, signed, initialled, or distributed.

The evidence was of such dimension that a complete illustration would exceed the limited space of this paper. Therefore, only a representative selection of evidence and the overall evaluation of Tribunal III regarding each defendant's individual guilt will be outlined here.

Altogether, Tribunal III sentenced four of the defendants to life imprisonment, six to prison terms between five and ten years and four defendants were acquitted. ${ }^{632} \mathrm{~A}$ mistrial was declared for two of the defendants. ${ }^{633}$

\footnotetext{
${ }^{630}$ See Part V A General Remarks.

${ }^{631}$ Taylor Final Report, above n 169, 86.

${ }^{632}$ Ibid, 169,174.

633 Ibid.
} 
1 The Tribunal's evaluation of the defendant's role in Nazi Germany

(a) Schlegelberger

Born on 23 October 1875, Franz Schlegelberger was the main defendant in the dock. ${ }^{634} \mathrm{He}$ looked back on a successful career in the German judicature: first, in the Weimar Republic, where he started working for the Ministry of Justice and became a State Secretary in $1931 ;^{635}$ and then, under the Nazi regime, where he stayed in this position and, upon Reich Minister Guertner's death, was appointed Acting Reich Minister of Justice in January $1941{ }^{636}$

He was the highest-ranked official in the Justice Trial and also a professor and author of several famous books. ${ }^{637} \mathrm{He}$ was known as an excellent jurist and was held in high esteem by legal experts. ${ }^{638}$ Many of his contemporaries described him as "the last decent jurist under Hitler"639.

In terms of power, Schlegelberger belonged more to the second-tier of Nazi jurists than to the more prominent group, which included Freisler and Thierack. ${ }^{640}$ However, it turned out to be a fortunate accident of history that he and his cohorts were in the dock, because they were much better representatives of the vast majority of jurists in Nazi Germany, who were mostly not fanatical National Socialists but conservative loyal servants of the government. ${ }^{641}$

\footnotetext{
${ }^{634}$ Justice Case, above n 9, 1081.

${ }^{635}$ Ibid, 1081-1082.

${ }^{636}$ Ibid.

${ }^{637}$ Baestlein, above n 12, 14; Justice Case, above n 9, 1081.

${ }^{638}$ Baestlein above n 12, 13, 16.

${ }^{639}$ Ibid, 13; See also Part III C 2 Conclusion.

${ }^{640}$ See Part III C 1 Selection criteria.

${ }^{641}$ Mueller, above n 120, 271.
} 
Indeed, Schlegelberger's role was typical for many jurists under the Nazi regime and, therefore, he became the symbolic figurehead of Germany's legal profession and its involvement in the reign of terror. ${ }^{642}$

Tribunal III dealt carefully with Schlegelberger's role in Nazi Germany. It considered that he was not a convinced Nazi and joined the NSDAP in 1938 only because he was ordered to do so by Hitler personally. ${ }^{643}$ Furthermore, it accepted his defence that the German administration of justice was under constant assaults by Himmler ${ }^{644}$ and other advocates of the police state and, therefore, he had feared that if he were to resign, a worse man would have taken his place. ${ }^{645}$

Indeed, this was proved when Schlegelberger's successor Thierack became Reich Minister of Justice in 1942, and the police usurped the functions of the administration of justice and murdered thousands of Jews and political prisoners. ${ }^{646}$ Nevertheless, Tribunal III adjudged him guilty on counts two and three of the indictment and sentenced him to imprisonment for life. ${ }^{647}$

Besides the fact that he received a gift of 100,000 Reichsmark from Hitler as appreciation upon his retirement as Acting Minister of Justice on 20 August $1942,{ }^{648}$ the evidence against him was overwhelming. ${ }^{649}$ Concerning his involvement in the unlawful Night and Fog Decree, ${ }^{650}$ Tribunal III stated: ${ }^{651}$

By his exhortations and directives, Schlegelberger contributed to the destruction of judicial independence. It was his signature on the decree of 7 February 1942 which imposed upon the Ministry of Justice and the

\footnotetext{
${ }^{642}$ Ibid; Baestlein, above n 12, 13.

${ }^{643}$ Justice Case, above n 9, 1082.

${ }^{644}$ Heinrich Himmler was the overall Chief of the infamous SS and, in that role, was the prime architect of the Holocaust. During the war, he became one of the most powerful men in the Third Reich. After being captured by the Allies in April 1945, he committed suicide by taking poison. "Heinrich Himmler" www.britannica.com (last accessed 18 March 2010). ${ }^{645}$ Justice Case, above n 9, 1086.

${ }^{646}$ Ibid.

${ }^{647}$ Ibid, 1200.

${ }^{648}$ Ibid, 1082.

${ }^{649}$ See generally Ibid, 1081-1087.

${ }^{650}$ See Part V A 2 (f) The Nacht und Nebel Erlass (Night and Fog Decree).

${ }^{651}$ Justice Case, above n 9, 1083.
} 
courts the burden of the prosecution, trial, and disposal of the victims of Hitler's Night and Fog. For this he must be charged with primary responsibility.

The Tribunal further stated that Schlegelberger did at least participate in the crimes against Poles and Jews. ${ }^{652}$ It referred to the Decree against Poles and Jews from 4 December 1941, whose first draft was made by Schlegelberger, and stated: ${ }^{653}$

He was guilty of instituting and supporting procedures for the wholesale persecution of Jews and Poles. Concerning Jews, his ideas were less brutal than those of his associates, but they can scarcely be called humane. ... Schlegelberger's draft constituted the basis on which, with certain modifications and changes, the law against Poles and Jews was enacted. In this respect he was not only guilty of participation in the racial persecution of Poles and Jews; he was also guilty of violation of the laws and customs of war by establishing that legislation in the occupied territories of the East.

In the end, Tribunal III summarised Schlegelberger's role and its relevance in Nazi Germany's legal system as follows: ${ }^{654}$

We are under no misapprehension. Schlegelberger is a tragic character. He loved the life of an intellect, the work of the scholar. We believe that he loathed the evil that he did, but he sold that intellect and that scholarship to Hitler for a mess of political pottage and for the vain hope of personal security.

(b) Klemm

Unlike Schlegelberger, Herbert Klemm was a convinced National Socialist. $^{655}$ Born in 1903, he joined the NSDAP as early as 1931 and worked in the Ministry of Justice from 1935 to $1940 .{ }^{656}$

652 Ibid.

${ }^{653}$ Ibid, 1083-1085.

${ }^{654}$ Ibid, 1087.

${ }^{655}$ Ibid, 1087-1088. 
Between July 1940 and March 1941, he fulfilled his war service in Holland as head of the department dealing with legal matters in the occupied Dutch territories, and from March 1941 to 1944, he served in the office of the Deputy of the Fuehrer and the Party Chancellery in Munich and Berlin. ${ }^{657}$ On 4 January 1944, he was appointed State Secretary in the Ministry of Justice and remained in this position until Germany's surrender. $^{658}$

Klemm was found guilty under counts two and three of the indictment and was sentenced to imprisonment for life. ${ }^{659}$ In evaluating Klemm's actions, Military Tribunal III could rely on clear evidence presented by the prosecution: While Klemm worked in the Party Chancellery, he made suggestions for strengthening the powers of police, and he took part in drafting the act to make the law relating to treason retroactive and applying to the annexed Eastern territories. ${ }^{660}$ As State Secretary in the Ministry of Justice, Klemm was effectively involved in the crimes committed by the German judiciary in the last one and a half years of the Nazi reign. ${ }^{661}$

Based on the evidence against him, the Tribunal stated: ${ }^{62}$

... Klemm knew of abuses in concentration camps. He knew of the persecution and oppression of the Jews and Poles and gypsies. He must be assumed to have known, from the evidence, the general basis of Nacht und Nebel procedure under the Department of Justice.

Additionally, Klemm was blamed for (1) denying clemency appeals of death sentences, which were obviously based on confessions made while getting tortured; ${ }^{663}(2)$ supporting and participating in the plan of the Nazi leaders to inspire the lynching of Allied airmen by the people of

\footnotetext{
${ }^{656}$ Ibid, 1087.

${ }^{657}$ Ibid; United Nations War Crimes Commission, above n 223, 14.

${ }^{658}$ Justice Case, above n 9, 1087.

${ }^{659}$ Ibid, 1107, 1200.

${ }^{660}$ Ibid, 1090.

${ }^{661}$ Baestlein, above n 12, 21.

${ }^{662}$ Justice Case, above n 9, 1094.

${ }^{663}$ Ibid, 1092-1095.
} 
Germany; ${ }^{664}$ and (3) as head of the department within the Ministry of Justice which was competent for Germany's penal institutions, being jointly responsible for the execution of approximately 800 political prisoners of the penitentiary at Sonnenburg in January $1945 .{ }^{665}$

In conclusion, Tribunal III stated: ${ }^{666}$

When Rothenberger was ousted as State Secretary because he was not brutal enough, it was Klemm who was chosen to carry on the Thierack program in closest cooperation with the heads of the Nazi conspiracy. Klemm was in the inner circle of the Nazi war criminals. He must share with his dead friend, Thierack, ... and his missing friend Bormann $\left[{ }^{667}\right]$, the responsibility, at a high policy level, for the crimes committed in the name of justice which fill the pages of this record. We find no evidence warranting mitigation of his punishment.

(c) Rothenberger

Curt Rothenberger was born on 30 June $1896 .{ }^{668}$ He joined the NSDAP on 1 May 1933 "for reasons of full conviction", as he had stated himself. ${ }^{669}$ From 1935 to 1942 , he was the President of the District Court of Appeals in Hamburg. ${ }^{670}$ During this period he was actively engaged as a Party official in several organisations of the NSDAP. ${ }^{671}$

In August 1942, Rothenberger was appointed State Secretary in the Reich Ministry of Justice, but left the Ministry in December 1943, due to

\footnotetext{
${ }^{664}$ Ibid, 1093-1099.

${ }^{665}$ Ibid, 1093, 1099-1106.

${ }^{666}$ Ibid, 1107.

667 Martin Bormann was the head of the Party Chancellery, and the head of the whole administrative machinery of the Nazi Party in Germany. He escaped after the war, but was indicted and sentenced to death in absentia by the International Military Tribunal at Nuremberg in 1946. "Martin Bormann" www.britannica.com (last accessed 18 March 2010).

${ }^{668}$ Schott, above n 429, 18.

${ }^{669}$ Justice Case, above n 9, 389.

${ }^{670}$ Ibid, 1107.

671 Ibid.
} 
bad relations with Minister Thierack. ${ }^{672}$ Afterwards, he served as a notary in Hamburg. ${ }^{673}$

Rothenberger was found guilty under counts two and three of the indictment and was sentenced to seven years imprisonment. ${ }^{674}$ Based on the given evidence, consisting of statements of Rothenberger himself, documents and testimonies of witnesses, ${ }^{675}$ Tribunal III stated: ${ }^{676}$

In conclusion, the evidence discloses a personality full of complexities, contradictions, and inner conflict. He was kind to many half-Jews, and occasionally publicly aided them, yet he was instrumental in denying them the rights to which every litigant is entitled. He fulminated publicly against the 'Schwarze Korps' $\left[{ }^{677}\right]$ for attacking the courts, yet he reproached judges for administering justice against Party officials and unquestionably used his influence toward achieving discriminatory action favorable to high Party officials and unfavorable to Poles and Jews. He wrote learnedly in favor of an independent judiciary, yet he ruled the judges of Hamburg with an iron hand. He protested vehemently against the practice of Party officials and Gestapo officers who interfered with the judges in pending cases, but he made arrangements with the Gestapo, the SS, and the SD whereby they were to come to him with their political affairs and then he instituted 'preview and review' of sentences with the judges who were his inferiors. He thought concentration camps wrong but concluded that they were not objectionable if third degree methods did not become a habit.

Although the Tribunal took into account that Rothenberger could not stand the brutality of the Nazi system and was "deceived and abused by his superiors" Thierack and Himmler, who Rothenberger considered his personal enemies, ${ }^{678}$ it concluded: ${ }^{679}$

The defendant Rothenberger is guilty of taking a minor but consenting part in the Night and Fog program. He aided and abetted in the program

\footnotetext{
${ }^{672}$ Schott, above n 429, 119, 148-156.

${ }^{673}$ Justice Case, above n 9, 1107.

${ }^{674}$ Ibid, 1118, 1200.

${ }^{675}$ See generally Ibid, 1107-1118.

${ }^{676}$ Ibid, 1117-1118.

${ }^{677}$ Das Schwarze Korps (The Black Corps) was the weekly newspaper of the SS. Randall L Bytwerk "Das Schwarze Korps" www.calvin.edu (last accessed 18 March 2010).

${ }^{678}$ Justice Case, above n 9, 1118.

${ }^{679}$ Ibid.
} 
of racial persecution, and notwithstanding his many protestations to the contrary he materially contributed toward the prostitution of the Ministry of Justice and the courts and their subordination to the arbitrary will of Hitler, the Party minions, and the police. He participated in the corruption and perversion of the judicial system.

(d) Lautz

Born in 1887, Ernst Lautz served as Chief Public Prosecutor at the People's Court in Berlin from 20 September 1939 until the end of the war. ${ }^{680}$ He became a member of the NSDAP in May 1933, but never actively participated in Party affairs. ${ }^{681}$ In his position at the People's Court he was the supervisor of the defendants Barnickel and Rothaug. ${ }^{62}$

Military Tribunal III found Lautz guilty upon counts two and three of the indictment and sentenced him to ten years imprisonment. ${ }^{683}$ It stressed especially that the proof of his guilt depended not solely on captured documents or the testimony of witnesses, but on his own sworn statements. ${ }^{684}$

In summary, he was convicted for his involvement "in enforcing the law against Poles and Jews which we deem to be part of the established governmental plan for the extermination of those races" $" 685$, for "a violation of the laws and customs of war in connection with prosecutions under the Nacht und Nebel decree",686, and for participating "in the perversions of the laws relating to treason and high treason under which Poles guilty of petty offenses were executed."

\footnotetext{
${ }^{680}$ Ibid, 1118-1119; Kastner "Der Dolch des Moerders war unter der Robe des Juristen verborgen: Der Nuernberger Juristen-Prozess 1947”, above n 317, 704.

${ }^{681}$ Justice Case, above n 9, 1119, 1128.

${ }^{682}$ Ibid, 1119.

${ }^{683}$ Ibid, $1128,1200$.

${ }^{684}$ Ibid, 1128.

${ }^{685}$ Ibid.

${ }^{686}$ Ibid.

${ }^{687}$ Ibid.
} 
In its evaluation of Lautz's role in the Nazi legal system, Tribunal III finally stated: ${ }^{688}$

There is much to be said in mitigation of punishment. Lautz was not active in Party matters. He resisted all efforts of Party officials to influence his conduct but yielded to influence and guidance from Hitler through the Reich Ministry of Justice, believing that to be required under German law. He was a stern man and a relentless prosecutor, but it may be said in his favor that if German law were a defense, which it is not, many of his acts would be excusable.

(e) Mettgenberg

Wolfgang Mettgenberg was born in $1882 .{ }^{689}$ He held the position of Representative of Chief in Departments III and IV of the Reich Ministry of Justice, which dealt with penal legislation and penal administration. ${ }^{690} \mathrm{He}$ was the supervisor of, and worked close together with, the defendant von Ammon, who was in charge of the Night and Fog section within Mettgenberg's subdivision. ${ }^{691}$

Mettgenberg was found guilty under counts two and three of the indictment and was sentenced to ten years imprisonment. ${ }^{692}$ The Tribunal convicted him primarily for his leading role in the accomplishment of Hitler's Night and Fog Decree. Based on Mettgenberg's own affidavit, ${ }^{693}$ it stated: ${ }^{694}$

... the defendant Wolfgang Mettgenberg frankly and fully admits his connection with the Hitler Night and Fog decree. His statements show that he exercised wide discretion and had extensive authority over the entire plan from the time the Night and Fog prisoner was arrested in

\footnotetext{
${ }^{688}$ Ibid.

${ }^{689}$ Kastner "Der Dolch des Moerders war unter der Robe des Juristen verborgen: Der Nuernberger Juristen-Prozess 1947”, above n 317, 704.

${ }^{690}$ Justice Case, above n 9, 1128-1129.

${ }^{691}$ Ibid, 1129.

692 Ibid, 1132, 1200.

${ }^{693}$ See generally Ibid, 1040-1041.

${ }^{694}$ Ibid, 1128.
} 
occupied territory and continuously after his transfer to Germany, his trial, and execution or imprisonment.

Overall, Tribunal III then concluded: ${ }^{695}$

The evidence shows beyond a reasonable doubt that that he acted as a principal, aided, abetted, and was connected with the execution and carrying out of the Hitler Night and Fog decree in violation of numerous principles of international law ...

(f) von Ammon

Wilhelm von Ammon was born in 1903 and joined the SA, the leading military force of the Nazi Party before and in the early years of the Nazi Government, ${ }^{696}$ in December 1933, shortly after the Nazis had taken over power in Germany. ${ }^{697}$

He started his service in the Reich Ministry of Justice in 1935 and was promoted Ministerial Counsellor in 1943, under the supervision of the defendant Mettgenberg. ${ }^{698}$ As stated above, von Ammon was responsible for the Night and Fog cases within Mettgenberg's subdivision. ${ }^{699}$ He was also a member of the NSDAP, which he joined in $1937 .^{700}$

Tribunal III found von Ammon guilty under counts two and three of the indictment and sentenced him to ten years imprisonment. ${ }^{701}$ Similarly to Mettgenberg, von Ammon was primarily charged with various responsibilities in the execution of Hitler's Night and Fog Decree.

Among other things, von Ammon was especially responsible for the decision of distributing the Night and Fog cases among the several Special

\footnotetext{
${ }^{695}$ Ibid, 1132.

696 "SA" www.britannica.com (last accessed 18 March 2010).

${ }^{697}$ Kastner "Der Dolch des Moerders war unter der Robe des Juristen verborgen: Der Nuernberger Juristen-Prozess 1947”, above n 317, 703; Justice Case, above n 9, 1132.

${ }^{698}$ Justice Case, above n 9, 1132.

${ }^{699}$ Ibid, 1132-1133.

${ }^{700}$ Ibid, 1132.

${ }^{701}$ Ibid, 1134, 1200.
} 
Courts and the People's Court, and von Ammon was granted a large degree of autonomy by Mettgenberg in his handling of individual cases, including the authority to confirm death sentences. ${ }^{702}$

Like Mettgenberg, von Ammon also proved the charges against him by his own testimonies. ${ }^{703}$ Thus, the Tribunal got a detailed overall picture of von Ammon's responsibility and stated as follows: ${ }^{704}$

\begin{abstract}
The defendant von Ammon held an executive position of responsibility involving the exercise of personal discretion. Within the ministry he was in charge of the section which handled Night and Fog cases. ... We have already quoted a note signed by von Ammon wherein he remarked that it was 'rather awkward' that the defendants should learn the details of their charges only during the trial and commented on the insufficiency of the translation facilities in the trial of French NN prisoners. Von Ammon is chargeable with actual knowledge concerning the systematic abuse of the judicial process in these cases.
\end{abstract}

(g) Joel

Born in 1903, ${ }^{705}$ Guenther Joel took office in the Ministry of Justice in 1933 as a Junior Public Prosecutor and rose to the rank of Ministerial Counsellor in 1941. ${ }^{706}$ Between 1937 and 1943, he was the Personal Referent $^{707}$ of Reich Minister Guertner and his successor Thierack in special cases. $^{708}$

In 1943, Joel left the Ministry after he was appointed Attorney General to the Supreme Provincial Court of Appeals in Hamm. ${ }^{709}$ Quickly, in August 1943, he was promoted Chief Prosecutor of the Court of Appeals

\footnotetext{
702 Ibid, 1133-1134.

${ }^{703}$ Ibid, 1041-1042, 1132.

${ }^{704}$ Ibid, 1134.

705 Kastner "Der Dolch des Moerders war unter der Robe des Juristen verborgen: Der Nuernberger Juristen-Prozess 1947”, above n 317, 703.

706 Justice Case, above n 9, 1134-1136.

${ }^{707}$ Personal Referent is a specific German term and is equivalent to a Ministerial Advisor.

708 Justice Case, above n 9, 1135.

${ }^{709}$ Ibid, 1136.
} 
in Hamm, responsible for a huge territory, including all of Westphalia and the district of Essen. ${ }^{710}$ In this position he stayed until the end of the war.

Joel was a Party man $^{711}$. He entered the NSDAP in May 1933 and became a member of the SS in January $1938 .{ }^{712}$ From 1937 to 1943 , he acted as Liaison Officer between the Ministry of Justice and the SS, SD and Gestapo. $^{713}$

Tribunal III adjudged Joel guilty under counts two, three and four of the indictment and sentenced him to ten years imprisonment. ${ }^{714} \mathrm{He}$ was convicted for his actions as a Referent in the Ministry of Justice, in which he dealt with many cases tried under the Decree against Poles and Jews from 4 December 1941, including the review and passing of death sentences for Poles and Jews who had committed alleged crimes against the Reich or the German occupation forces. ${ }^{715}$

Also, he was convicted for his work as Liaison Officer between the Ministry and the SS and Gestapo, which "was productive and satisfactory in the carrying out of the plan or scheme of racial persecution and extermination of Poles and Jews. ${ }^{, 716}$ Furthermore, the Tribunal blamed him for his work as Chief Prosecutor of the Court of Appeals in Hamm, in which he was in charge of the Night and Fog programme. ${ }^{717}$ Lastly, he was convicted for his membership in the SS and SD, which the judgment of the International Military Tribunal had declared to be criminal organisations. ${ }^{718}$

Many documents proved his guilt and, therefore, in its judgment the Tribunal concluded: $:^{719}$

The defendant Joel is chargeable with knowledge that the Night and Fog program from its inception to its final conclusion constituted a violation

\footnotetext{
${ }^{710}$ Ibid, 1137.

${ }^{711}$ Ibid, 1134.

${ }^{712}$ Ibid, 1134-1135.

${ }^{713}$ Ibid, 1135-1136.

${ }^{714}$ Ibid, 1142, 1200-1201.

${ }^{715}$ Ibid, 1142 .

${ }^{716}$ Ibid, 1136-1137.

${ }^{717}$ Ibid, 1137.

${ }^{718}$ Ibid, 1134.

${ }^{719}$ Ibid, 1138, 1142.
} 
of the laws and customs of war. ... As Referent in the department of justice and as liaison officer between the department and the SS, Joel obtained extensive information and exercised far-reaching power in the execution of the law against Jews and Poles. He therefore took an active part in the execution of the plan or scheme for the persecution and extermination of Jews and Poles. Concerning Joel's membership in the SS and $\mathrm{SD}$, a consideration of all of the evidence convinces us beyond a reasonable doubt that he retained such membership with full knowledge of the criminal character of those organizations.

(h) Rothaug

Oswald Rothaug was born on 17 May $1897 .^{720} \mathrm{He}$ worked as a lawyer, public prosecutor and local court judge before he was appointed Director of the District Court in Nuremberg in April $1937 .^{721}$ In this position, which he held until May 1943, he was Chairman of the Court of Assizes, of a penal chamber and of the Nuremberg Special Court. ${ }^{722}$ In May 1943, he was promoted Senior Public Prosecutor at the People's Court in Berlin. $^{723}$

Rothaug joined the NSDAP in $1938 .^{724} \mathrm{He}$ was an active Party member and an "honorary collaborator" of the SD. ${ }^{725}$ Furthermore, he was Executive Chief of the Lawyers' League in the District of Franconia. ${ }^{726}$

Rothaug became symbolic of the worst excesses of the racist and evil Nazi ideology which took over the German judiciary after $1933 .{ }^{727}$ Military Tribunal III described him and the defendant Oeschey as "judges who with fanatical zeal enforced the will of the Party"728.

\footnotetext{
${ }^{720}$ Ibid, 1143.

${ }^{721}$ Ibid.

722 Ibid.

723 Ibid.

${ }^{724}$ Ibid.

${ }^{725}$ Ibid, 1143-1144.

${ }^{726}$ Ibid, 1144.

${ }^{727}$ Ibid, 1156 .

${ }^{728}$ Ibid, 1025; See also Part V A 1 (f) (iii) Outcome.
} 
The evidence against Rothaug was voluminous and verified his "attitude of virulent hostility" towards Poles and Jews. ${ }^{729}$ Many documents and witness statements of his own associates, including judges, prosecutors, defence lawyers and medical experts, proved his guilt. ${ }^{730}$ Hence, the Tribunal found Rothaug guilty on count three of the indictment and sentenced him to imprisonment for life. ${ }^{731}$

The judgment was primarily based on three exemplary cases, which were tried in front of the Special Court at Nuremberg with Rothaug as the Presiding Judge:

In the first trial, Rothaug adjudged two Polish girls of minor age within one hour for alleged sabotage and sentenced them to death, although they had repudiated their confessions made during the interrogation by the Gestapo and their lawyer had objected that a proper defence was impossible because he was summoned by Rothaug just two hours before the start of the trial. $^{732}$ They were executed just four days after the trial. ${ }^{733}$

In the second trial, a 25 year old Polish farmhand was accused to have made indecent advances to his employer's wife. ${ }^{734} \mathrm{He}$ was sentenced to death under the Decree against Poles and Jews from 4 December 1941 and was subsequently executed. ${ }^{735}$ Rothaug's judgment included the words: "The whole inferiority of the defendant, I would say, lies in the sphere of character and is obviously based on his being a part of Polish subhumanity, or in his belonging to Polish subhumanity."736

The third trial was the well-known case of Leo Katzenberger, a 68 year old Jewish merchant and the head of the Jewish community in Nuremberg. ${ }^{737} \mathrm{He}$ was accused of racial pollution with the 30 year old

\footnotetext{
${ }^{729}$ Justice Case, above n 9, 1144.

${ }^{730}$ Ibid.

${ }^{731}$ Ibid, 1156, 1201.

732 Ibid, 1146.

${ }^{733}$ Ibid, 1147.

734 Ibid.

735 Ibid, 1150 .

${ }^{736}$ Ibid, 1149.

${ }^{737}$ Ibid, 1150; See generally Hartmut Frommer and Kathrin Westner "Die Vernichtung von Leo Katzenberger durch das Sondergericht Nuernberg" (1998) 85 Mitteilungen des Vereins fuer Geschichte der Stadt Nuernberg 315 et seq.
} 
German woman Irene Seiler, who had given a sworn statement that Katzenberger and her family had been close friends for many years and that their relationship was only a friendly and fatherly one without any sexual intercourse. $^{738}$

After the indictment appeared to fail, because there was no evidence at all, Rothaug organised that the case was to be tried before his Special Court. ${ }^{739} \mathrm{He}$ ordered that Katzenberger be indicted with racial defilement in combination with a charge under the Decree against Public Enemies, which was the only possibility to give a death sentence, and that Seiler was indicted with the charge of perjury, so she was precluded as a witness for Katzenberger. $^{740}$

Prior the start of the trial, Rothaug told the medical counsellor of the court that Katzenberger "would be beheaded anyhow"741 and, on the doctor's objection that his guilt was questionable, he replied: "It is sufficient for me that the swine said that a German girl had sat upon his lap."742 During the recess after the introduction of evidence was concluded, Rothaug talked to the prosecutor and urged him to ask for a death sentence for Katzenberger. ${ }^{743}$ He also gave him suggestions for arguments. ${ }^{744}$ In the end, Katzenberger was sentenced to death, and Seiler was sentenced to two years imprisonment. $^{745}$

In its conclusion, Tribunal III evaluated Rothaug's role in the Nazi judicial system as follows: ${ }^{746}$

From the evidence it is clear that these trials lacked the essential elements of legality. In these cases the defendant's court, in spite of the legal sophistries which he employed, was merely an instrument in the program of the leaders of the Nazi State of persecution and extermination. That the number the defendant could wipe out within his competency was smaller

\footnotetext{
${ }^{738}$ Justice Case, above n 9, 1150-1151.

${ }^{739}$ Ibid, 1151.

${ }^{740}$ Ibid.

${ }^{741}$ Ibid, 1152.

742 Ibid.

${ }^{743}$ Ibid.

744 Ibid.

${ }^{745}$ Frommer and Westner, above $\mathrm{n} 737,319$

${ }^{746}$ Justice Case, above n 9, 1155-1156.
} 
than the number involved in the mass persecutions and exterminations by the leaders whom he had served, does not mitigate his contribution to the program of those leaders. His acts were more terrible in that those who might have hoped for a last refuge in the institutions of justice found these institutions turned against them and a part of the program of terror and oppression.

The individual cases in which Rothaug applied the cruel and discriminatory law against Poles and Jews cannot be considered in isolation. It is of the essence of the charges against him that he participated in the national program of racial persecution. It is of the essence of the proof that he identified himself with this national program and gave himself utterly to its accomplishment. He participated in the crime of genocide. ...

By his manner and methods he made his court an instrumentality of terror and won the fear and hatred of the population. From the evidence of his closest associates as well as his victims, we find that Oswald Rothaug represented in Germany the personification of the secret Nazi intrigue and cruelty. He was and is a sadistic and evil man.

(i) Barnickel, Petersen, Nebelung and Cuhorst

The defendants Paul Barnickel, Hans Petersen, Guenther Nebelung and Hermann Cuhorst were all acquitted by Military Tribunal III. ${ }^{747} \mathrm{~A}$ closer look at these defendants, therefore, is not necessary because the danger of victor's justice in the individual cases is out of question.

Interestingly enough, though, is the fact that the Tribunal was generally convinced that the defendant Cuhorst committed crimes as defined in Control Council Law No. $10 .^{748}$ It stated: ${ }^{749}$

There are many affidavits and much testimony in the record as to the defendant's character as a fanatical Nazi and a ruthless judge. There is

\footnotetext{
${ }^{747}$ Ibid, 1156-1159.

${ }^{748}$ Ibid, 1158.

${ }^{749}$ Ibid.
} 
also much evidence as to the arbitrary, unfair, and unjudicial manner in which he conducted his trials.

Nevertheless, Tribunal III did not find him guilty for the only reason that the records of the cases, which were tried by Cuhorst as Chief Justice of the Special Court in Stuttgart, had been destroyed when the Palace of Justice in Stuttgart was burned. ${ }^{750}$ The decision was explained as follows: ${ }^{751}$

From the evidence available, this Tribunal does not consider that it can say beyond a reasonable doubt that the defendant was guilty of inflicting the punishments which he imposed on racial grounds or that it can say beyond a reasonable doubt that he used the discriminatory provisions of the decree against Poles and Jews to the prejudice of the Poles whom he tried.

\section{(j) Oeschey}

Together with Rothaug, whose successor as Chief Justice of the Special Court in Nuremberg he became in 1943, Rudolf Oeschey was characterized as one of "the guiding, if not controlling, spirits of the Special Court at Nuernberg, which was known as the most brutal of the special courts in Germany.,"752

Born in $1903,{ }^{753}$ Oeschey early became a member of the NSDAP in 1931. ${ }^{754}$ He served in several offices of the Nazi Party until, in 1940, he was provisionally commissioned with the direction of the legal office of the NSDAP in the District of Franconia and the leadership of the District of Franconia in the National Socialist Lawyers League. ${ }^{755}$

\footnotetext{
${ }^{750}$ Ibid.

751 Ibid.

752 Ibid, 1159.

${ }^{753}$ Kastner "Der Dolch des Moerders war unter der Robe des Juristen verborgen: Der Nuernberger Juristen-Prozess 1947”, above n 317, 704.

${ }^{754}$ Justice Case, above n 9, 1159.

755 Ibid.
} 
After Rothaug's promotion to Berlin, Oeschey was appointed Director of the District Court in Nuremberg. ${ }^{756} \mathrm{He}$ held this position until February 1945, when he was drafted into the German Army. ${ }^{757}$ For the period from 4 April 1945 to 14 April 1945, he was released to serve as Chairman of the Civilian Court Martial at Nuremberg. ${ }^{758}$

Tribunal III found Oeschey guilty on counts three and four of the indictment and sentenced him to imprisonment for life. ${ }^{759}$ Many cases gave evidence of his arbitrary character, but the Tribunal analysed only two in detail: ${ }^{760}$

In the first case, Oeschey found a Polish woman guilty of a violation under the Decree against Poles and Jews, and her boyfriend, a Ukrainian male, he found guilty for assisting her to commit this alleged crime after a harmless skirmish with their employer, a German farmer, had occurred. ${ }^{761}$ Both were sentenced to death, and the evidence in the Justice Trial proved that Oeschey imposed his will upon his two fellow judges and had induced them to concur. ${ }^{762}$ Accordingly, the Tribunal concluded:

In this case Oeschey, with evil intent, participated in the governmentorganized system for the racial persecution of Poles. This is also a case of such a perversion of the judicial process as to shock the conscience of mankind.

The other case was the one of Count Montgelas, who was tried and convicted for having allegedly made insulting remarks concerning Hitler to a woman in a private room. ${ }^{763}$ He was sentenced to death by the Nuremberg Civilian Court Martial with Oeschey as the Presiding Judge. ${ }^{764}$ By violating almost all rules of a fair trial, which were also valid for courts martial, this

\footnotetext{
${ }^{756}$ Ibid.

${ }^{757}$ Ibid.

758 Ibid.

${ }^{759}$ Ibid, 1170, 1201.

${ }^{760}$ Ibid, 1159.

${ }^{761}$ Ibid, 1159-1160.

762 Ibid, 1161.

${ }^{763}$ Ibid, 1163-1164.

${ }^{764}$ Ibid, 1163.
} 
case was one of the most terrifying examples of the Nazi judicial practice. ${ }^{765}$ Tribunal III summarised as follows: ${ }^{766}$

\begin{abstract}
Thus, on the last days of the war, when the American Army was almost at the gates of Nuernberg, and within a month of the total collapse of German opposition, a sick man, after solitary confinement, is indicted on 3 April, tried on 5 April, and shot on 6 April without the knowledge of his counsel in secret proceedings, and without the benefit of witnesses who would have testified for him. Such a mock trial is not a judicial proceeding but a murder.
\end{abstract}

The most shocking facts about Oeschey's character were not given by the captured documents, but by many witnesses who had been his associates. ${ }^{767}$ Most of them described Oeschey as a racist, especially in regard to Poles, and a fanatical Nazi who often had announced before trial that the defendant will be executed. ${ }^{768}$ For example, a statement of Hermann Mueller, who was a prosecutor at the Nuremberg Special Court and a witness at the Justice Trial, is quoted here: "Oeschey was the most brutal judge that I have ever known in my life and a most willing instrument of the Nazi terroristic justice." 769

Based on such statements and the documentary evidence, it was relatively easy for Tribunal III to get a profound picture of Oeschey's personality and his role in the Nazi judicial system. Thus, at the end of its analysis, it concluded: "In view of the sadistic attitude and conduct of the defendant, we know of no just reason for any mitigation of punishment."770

\footnotetext{
${ }^{765}$ Ibid, 1162-1164.

${ }^{766}$ Ibid, 1164.

${ }^{767}$ See generally Ibid, 1165-1168.

${ }^{768}$ Ibid, 1165-1167.

${ }^{769}$ Ibid, 1165.

${ }^{770}$ Ibid, 1170.
} 
(k) Altstoetter

Josef Altstoetter, born in 1892, is the only defendant in the Justice Trial, who was found guilty on count four of the indictment only. ${ }^{771}$ Besides his professional career in the Ministry of Justice, where he was promoted Chief of the Civil Law and Procedure Division in 1943, he was a very active member within the Nazi Party. ${ }^{772}$

When the Nazis took over power in Germany, he had been a member of the paramilitary organisation Stahlhelm, which was absorbed by the SA in $1934 .^{773}$ In the following years, he developed a good relationship to Heinrich Himmler and, on his request, Altstoetter resigned from the SA to become a member of the SS in $1937 .{ }^{774}$ In 1938 , he also joined the NSDAP, which later awarded him the Golden Party Badge for service to the Party. ${ }^{775}$

Altstoetter was a good friend to Himmler and Ernst Kaltenbrunner ${ }^{776}$ and, probably for that reason, received several promotions in the SS. ${ }^{777}$ The peak of his SS career was reached in 1944, when he was promoted to the rank of Oberfuehrer, which was a very high position within the organisation. ${ }^{778}$

Tribunal III sentenced Altstoetter to five years imprisonment. ${ }^{779}$ It referred to the judgment of the International Military Tribunal, which in detail had described the criminal activities of the SS, such as the deportation

\footnotetext{
${ }^{771}$ Ibid, 1170, 1177.

${ }^{772}$ Ibid, 1171.

773 Ibid.

774 Ibid.

775 Ibid.

${ }^{776}$ Ernst Kaltenbrunner was Chief of the SD and Gestapo from 1943 until the end of the war. In this position, he was in charge of the system of Nazi concentration camps throughout Europe and controlled the administrative apparatus for carrying out the extermination of European Jewry. He was indicted as a war criminal and sentenced to death by the International Military Tribunal in 1946. "Ernst Kaltenbrunner" www.britannica.com (last accessed 18 March 2010).

777 Justice Case, above n 9, 1176.

${ }^{778}$ Ibid, 1172.

${ }^{779}$ Ibid, 1201.
} 
and extermination of the Jews, the widespread murder and ill-treatment of the civilian population in occupied territories and the brutal treatment of the inmates of concentration camps. ${ }^{780}$

The evidence of Altstoetter's connection with the SS was based primarily on his personnel file, his correspondence with SS leaders and his own testimony, and it showed clearly that he knew about the crimes committed by the SS, for example, the evacuation of Jews in Austria. ${ }^{781}$

Thus, in conclusion, the Tribunal stated as follows: $:^{782}$

He accepted and retained his membership in the SS, perhaps the major instrument of Himmler's power. Conceding that the defendant did not know of the ultimate mass murders in the concentration camps and by the Einsatzgruppen, he knew the policies of the SS and, in part, its crimes. Nevertheless, he accepted its insignia, its rank, its honors, and its contacts with the high figures of the Nazi regime. These were of no small significance in Nazi Germany. For that price he gave his name as a soldier and a jurist of note and so helped to cloak the shameful deeds of that organization from the eyes of the German people.

(1) Engert and Westphal

Karl Engert, Vice President of the infamous People's Court, and Carl Westphal, a high official in the Reich Ministry of Justice, were both indicted but not tried. ${ }^{783}$

Engert became seriously ill and was not able to be present in court for most of the trial, so Tribunal III declared a mistrial. ${ }^{784}$ Westphal

\footnotetext{
${ }^{780}$ Ibid, 1173-1175.

${ }^{781}$ Ibid, 1171, 1176.

${ }^{782}$ Ibid, 1176-1177.

${ }^{783}$ Ibid, 3.

${ }^{784}$ Ibid, 954.
} 
committed suicide in his cell in the Nuremberg jail after the indictment was issued, but before the opening of the trial. ${ }^{785}$

\section{The Tribunal's relatively mild sentencing}

Many people criticised the sentences in the Justice Trial as too mild, which is fully understandable if one looks at other trials conducted at Nuremberg. Death sentences were given in the major trial before the International Military Tribunal, and in Case No. 1 (Medical Trial), Case No. 4 (Pohl Trial) and Case No. 9 (Einsatzgruppen Trial) of the subsequent Nuremberg Trials. ${ }^{786}$ The Deputy Chief Prosecutor in the Justice Trial, Charles M LaFollette, stated in a review of the trial in 1948: "The judgment was attacked for its leniency by more Germans than Americans."787

Hence, the question arises why none of the defendants in the Justice Trial was sentenced to death and why most of the given prison terms, except for the lifelong sentences, were relatively short? Defendants like Rothaug or Oeschey may have been appropriate candidates for the death penalty.

At first, the perspectives of the judges of Tribunal III have to be considered, because it could be a reason for the mildness of the sentences. Besides the fact that the members of the Tribunal were sitting opposite of former peers, they were confronted with a unique situation in world history, namely the task to evaluate the role of jurists, who usually did nothing else but to apply the existing laws of their country.

Additionally, they did not judge over some ordinary cads but representatives of Germany's academic elite, who were able to speak and argue in a proper way and sometimes showed regret. Especially Schlegelberger left a good personal impression on the Tribunal. ${ }^{788}$

\footnotetext{
${ }^{785}$ Ibid, 3.

${ }^{786}$ Beigbeder, above n 20, 38; Whitney R Harris, above n 18, 546, 548, 551.

${ }^{787}$ LaFollette, above n 280, 12.

${ }^{788}$ See generally Justice Case, above n 9, 1081-1087.
} 
Therefore, the judges of Tribunal III had to deal with an emotional pressure based on the unanswerable and terrifying question: What would I have done in the situation of the defendants?

Another reason was the social and political situation in 1947. In his Final Report, Chief Prosecutor Telford Taylor explained the differences in the sentences of the 12 subsequent Nuremberg Tribunals as follows: ${ }^{789}$

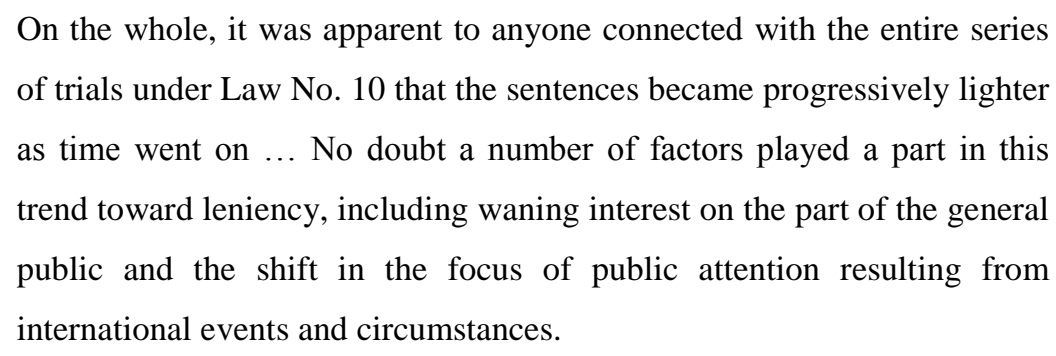

Indeed, the public interest shifted away from the war crimes trials after the major Nazis had been convicted by the International Military Tribunal, and also the US policy in regard to Germany's war criminals changed dramatically after it became clear that a new democratic Germany was needed as an ally in the context of the upcoming Cold War. ${ }^{790}$

As analysed before, the judges of Tribunal III evaluated and judged with a great sense of impartiality, ${ }^{791}$ Nevertheless, they were human beings and could hardly free themselves completely from these developments. However, the relative mildness of the sentences passed by Tribunal III disprove the accusation that the verdicts in the Justice Trial were based on victor's justice.

\section{Conclusion}

The judges of US Military Tribunal III were confronted with an extremely difficult task: to put themselves in the position of a leading

\footnotetext{
${ }^{789}$ Taylor Final Report, above n 169, 92.

${ }^{790}$ Friedman, above n 2, 91-92.

${ }^{791}$ See Part III A 2 Independence of the judges from US post-war politics.
} 
German jurist under the Nazi Government and evaluate the actions that were done. In doing so, it has to be taken into consideration, and the judges probably did, that at the time, people of any nation depended much more on their home country than today.

The world was not as international, and emigration was an option with a much bigger personal sacrifice than it is today. Most of the people in the 1930s were deeply rooted in the communities where they had grown up, and persons with a social background and standing like the defendants had even stronger roots to their local area, because they belonged to the guiding elite of those communities. Additionally, some of the defendants had already reached an age, which would have made it even more difficult for them to leave their beloved home country.

In the end, the Tribunal evaluated the role of the defendants reasonably and passed appropriate sentences. Persons like Schlegelberger or Rothenberger did obviously struggle with the development of law and their role in Nazi Germany's judicial system. Nevertheless, they were - directly or indirectly - responsible for the atrocities committed in the name of law in Germany.

Tribunal III did not only punish them for their actions but sent an important message for future generations: that individuals of such high intelligence and good standing should have taken their leading roles in society not only for their personal benefits but for the good of moral and conscience and, therefore, should have probably resisted or left their country.

Individually, in my opinion, all defendants were adjudged in a fair and just manner without signs of victor's justice. However, regarding the responsibility of German judges, German Professor Eberhard Schmidt, in 1947, stated that it was not the judiciary but the legislature who undermined 
the justice system and, therefore, the responsibility for it cannot be heaped upon the judiciary but only on the legislature. ${ }^{792}$

Nevertheless, it is a given fact that sometimes courts had exceeded the possible range of punishment in Nazi laws by " 150 per cent" sentenced political opponents or Poles and Jews to death without any need. ${ }^{794}$ Therefore, although personally an opponent of the death penalty, I am convinced that the life sentences handed down by the Tribunal were deserved, as one can possibly argue that only defendants like Rothaug and Oeschey may have deserved the death penalty.

In the case of Altstoetter, there are signs of weak evidence as he was convicted only for his membership in the SS, with the explanation that he knew about the crimes committed by this organisation. However, with respect to the legal basis and background of Tribunal III, including the obligation to apply the rules of Control Council Law No. 10 and US Military Ordinance No. 7, his conviction was understandable.

When one looks at his sentence of just five years imprisonment, the mildest sentence of all convicted defendants in the Justice Trial, it becomes clear that the Tribunal took his less severe guilt into account.

Furthermore, the acquittals of four of the defendants definitely disprove the accusation of victor's justice. Especially the case of Cuhorst clarifies that Tribunal III held onto fundamental principles of criminal law, although all available evidence and facts strongly indicated his guilt.

The Tribunal adhered to the principle in dubio pro reo (when in doubt, for the accused) and acquitted him because it was not able to say "beyond a reasonable doubt" that he was guilty. ${ }^{795}$ Unlike the Nazi legal practice, which disregarded this principle among many others, it sent out a strong signal to future tribunals to follow the basic rules of criminal law and justice, free of emotional feelings and the public cry for vengeance.

\footnotetext{
${ }^{792}$ Kramer "Richter vor Gericht: Die juristische Aufarbeitung der Sondergerichtsbarkeit", above $\mathrm{n} 342,168$.

${ }^{793}$ Translated from the German "einhundertfuenfzigprozentig". Ibid, 169.

794 Ibid.

${ }^{795}$ Justice Case, above n 9, 1158.
} 
With respect to the atrocities committed by the Gestapo and in concentration camps, all of the defendants had claimed that they did not know about it. ${ }^{796}$ On this, the Tribunal stated as follows: ${ }^{797}$

The thousands of Germans who took part in the atrocities must have returned from time to time to their homes in the Reich. The atrocities were of a magnitude unprecedented in the world. Are we to believe that no whisper reached the ears of the public or of those officials who were most concerned? Did the defendants think that the nation-wide pogrom of November 1938 officially directed from Berlin and Hitler's announcement to the Reichstag threatening the obliteration of the Jewish race in Europe were unrelated? At least they cannot plead ignorance concerning the decrees which were published in their official organ, 'The Reichsgesetzblatt'. ... They read The Stuermer $\left[{ }^{798}\right]$. They listened to the radio. They received and sent directives. They heard and delivered lectures. This Tribunal is not so gullible as to believe these defendants so stupid that they did not know what was going on. One man can keep a secret, two men may, but thousands never.

However, in the end, Tribunal III did not settle for this assumption. Instead it looked accurately and in detail at each defendant's actions and responsibilities, and it relied on the individually given evidence. Therefore, once more, it has to be said that in regard to the evaluation of the defendants' individual roles, victor's justice was not exercised by the Tribunal.

\footnotetext{
${ }^{796}$ Ibid, 1079.

${ }^{797}$ Ibid, 1080-1081.

${ }^{798}$ The Stuermer was a popular but infamous newspaper published between 1923 and 1945 in Germany. Its only aim was to denounce Jews in crude, vicious and vivid ways. The editor Julius Streicher was indicted as a war criminal and sentenced to death by the International Military Tribunal in 1946. Randall L Bytwerk "Der Stuermer" www.calvin.edu (last accessed 18 March 2010); "Julius Streicher" www.britannica.com (last accessed 19 March 2010).
} 


\section{LEGACY OF THE TRIAL}

From today's perspective, the 13 Nuremberg Trials have been one of the most remarkable events in world history and changed the rules of international law forever.

With a focus on the Justice Trial, this chapter will firstly outline how Nuremberg was the starting point for the establishment of a new international criminal law; it will be concluded that these new rules and principles formed a proper basis for the future treatment of war criminals.

Secondly, it will be analysed why the US war crimes trial programme, in the end, failed and whether the Justice Trial has to be seen as an example of victor's justice because it remained the only trial by the US Military Government against Nazi jurists after World War II. In this context, it will also be examined why all convicted defendants were released long before the end of their prison terms, although the US officials had always claimed that the sentences were not based on the rule of the victors but the rule of law.

In the end, a conclusion will be drawn stating that in the context of the aftermath of World War II the Justice Trial cannot be seen as an example of victor's justice.

\section{A The Establishment of a New International Criminal Law}

\section{Development}

From the very beginning at the London Conference in 1945, the United States intended that the trials against the German war criminals were 
not only for punishing the perpetrators of Nazi Germany, but to establish a new world order in which not the states but the people were the subjects of the law. ${ }^{799}$

Since the Peace of Westphalia in 1648, which marked the end of the devastating 30 Years' War in Europe, it was the right of a sovereign state to make war against other sovereign states and to treat its own population as they liked. ${ }^{800}$ That was not good, not evil, not unfair and not illegal in the context of that time, it was simply the world order for 300 years. ${ }^{801}$

Indeed, although international treaties and war conventions existed to protect the civilian population, in general only states were subject to the international law, and individuals like the defendants in the Justice Trial could not be made responsible for their actions, which they performed as an instrument or organ of the state. ${ }^{802}$

The Nuremberg Trials changed this old world order forever. Besides the first trial against the major Nazi war criminals, which established that state leaders can be held individually responsible for aggression, war crimes and crimes against humanity, ${ }^{803}$ the subsequent Nuremberg proceedings additionally "established clear notions of enslavement, torture, deportation, slave labour, and superior responsibility, all of which helped clarify the content of crimes against humanity and war crimes as international crimes bearing individual criminal liability." 804

The new concept of crimes against humanity and the new principle of individual responsibility meant a revolution in international criminal law

\footnotetext{
799 Thomas Darnstaedt "Die Neuordnung der Welt" (23 October 2006) 43 Der Spiegel Hamburg (Germany) 160 www.spiegel.de (last accessed 19 March 2010).

${ }^{800}$ Darnstaedt "Das Weltgericht", above n 227; See also Rosenberg, above n 397, 1550.

${ }^{801}$ Darnstaedt "Das Weltgericht", above n 227.

${ }^{802}$ Woetzel, above n 14, 68; See also Part IV A 3 Individual liability and Part V A 1 (f) The execution of the law in Nazi Germany.

${ }^{803}$ Burchard, above $\mathrm{n} 466,701$.

${ }^{804}$ Jens Ohlin "US Military Tribunals sitting at Nuremberg" in Antonio Cassese (ed) The Oxford Companion to International Criminal Justice (Oxford University Press, Oxford, 2009) 561.
} 
at the time. ${ }^{805}$ Following this, the argument of obedience to superior orders was once for all denied as an absolute defence in international law. ${ }^{806}$

The Justice Trial, in particular, established several new doctrines: (1) that crimes against humanity can include crimes committed by national authorities against its own nationals "where such crimes were committed through systematic government approved procedures committed against populations or amounted to persecutions on political, racial, or religious grounds" ${ }^{\sharp 07}$; (2) that judges could not benefit from the doctrine of judicial immunity and, therefore, would be liable for their judicial actions if the evidence shows that the courts "were neither independent nor impartial, but resembled administrative tribunals acting under directives from above in a quasi-judicial manner" ${ }^{808}$; and (3) that the infliction of mental cruelty, such as committed under the Night and Fog Decree, can constitute inhumane treatment. $^{809}$

Overall, the Nuremberg Trials laid the foundation of modern international criminal law. The concept of crimes against humanity served as a basis and inspiration for the Universal Declaration of Human Rights of 1948, the Genocide Convention of 1948 and the extension of the four Geneva Conventions of $1949 .{ }^{810}$ Also, the so called Nuremberg Principles were adopted by the United Nations in 1950, and serve today as a solid basis for international war crimes tribunals. ${ }^{811}$

Unfortunately for the development of international law, the Iron Curtain during the Cold War re-established the old principle of state sovereignty "so that in the 1980s the Nuremberg's legacy was indeed that of failure. $" 812$

\footnotetext{
${ }^{805}$ Bassiouni, above n 4, 535; See also Rosenberg, above n 397, 1550.

${ }^{806}$ Beigbeder, above n 20, 49; See also Rosenberg, above n 397, 1550.

${ }^{807}$ Gustafson, above n 365, 583; Justice Case, above n 9, 982.

${ }^{808}$ Gustafson, above n 365, 583; Justice Case, above n 9, 1024-1025; See also Part IV A 3 Individual liability.

${ }^{809}$ Gustafson, above n 365, 583, Justice Case, above n 9, 1058-1059.

${ }^{810}$ Beigbeder, above n 20, 49; Burchard, above n 466, 701.

811 Burchard, above n 466, 701; See generally United Nations International Law Commission Principles of International Law Recognized in the Charter of the Nuernberg Tribunal and in the Judgment of the Tribunal (1950).

${ }^{812}$ Burchard, above n 466, 701.
} 
Nevertheless, after the end of Communism in Eastern Europe, the Nuremberg ideas revived and found their ultimate establishment within the creation of new international war crimes tribunals, such as the Tribunals for Ex-Yugoslavia (ICTY) and Rwanda (ICTR) in the 1990s. ${ }^{813}$ The provisional climax was reached by the Rome Statute of 1998 and the subsequent installation of the permanent International Criminal Court (ICC) in $2002 .^{814}$

Additionally, the Nuremberg rules and principles formed the legal basis for many other courts, such as the South African Truth and Reconciliation Commission (1995-1998), ${ }^{815}$ the Special Court for Sierra Leone (since 2002), ${ }^{816}$ the Special Tribunals for Lebanon (since 2009) and Cambodia (since 2007), ${ }^{817}$ the East-Timor Commission for Reception, Truth and Reconciliation (2002-2005), ${ }^{818}$ the Iraq Tribunal (2005-2006), ${ }^{819}$ and the German civil courts, who carried out the Wall-shooters' trials against former East German soldiers and officials (1991-2005). ${ }^{820}$

\section{Criticism}

The Nuremberg Trials revolutionised the international law by threatening future national leaders and their subordinates with the possibility of being tried for starting an aggressive war or committing war crimes and crimes against humanity. ${ }^{821}$ However, it did not lead to the end of wars and war crimes. Between 1945 and 1998, international conflicts and tyrannical

\footnotetext{
${ }^{813}$ Ibid; Beigbeder, above n 20, 49; See also "International Criminal Tribunals and Special Courts" www.globalpolicy.org/international-justice (last accessed 19 March 2010).

814 Burchard, above n 466, 701; See also "The International Criminal Court" www.globalpolicy.org/international-justice (last accessed 19 March 2010).

815 See generally "Truth and Reconciliation Commission" www.justice.gov.za (last accessed 19 March 2010).

${ }_{817}^{816}$ See generally "International Criminal Tribunals and Special Courts", above n 813 .

${ }^{817}$ Ibid.

${ }^{818}$ Ibid.

${ }^{819}$ Ibid.

${ }^{820}$ See generally Michael Brettin "Die Prozesse gegen die Mauerschuetzen und ihre Hintermaenner" (5 May 2009) Berliner Kurier Berlin (Germany) www.berlinonline.de/berliner-kurier (last accessed 19 March 2010).

${ }^{821}$ Harry Reicher “A Turning Point in the Law, A Growing Momentum" (2004) 26 Nat'l L $\mathrm{J} 38,38$.
} 
regimes caused an estimated 170 million casualties, and most of the perpetrators of these crimes have never faced a trial. ${ }^{822}$

Therefore, some critics state that the Nuremberg Trials did more harm than good to society and the rule of law, because the fact that only a very small amount of Nazi criminals were finally tried did not deter future perpetrators from committing war crimes but almost encouraged them. ${ }^{823}$ Author Ellis Washington expressed this opinion as follows: ${ }^{824}$

... the Nuremberg Trials were ultimately, pathetic show trials concocted by the Allies purely out of expediency and with the intent to dispense symbolic justice so that they could get on with the work of rebuilding Europe which had been so utterly devastated by the war.

On the other hand, it has to be taken into account that the development of Western Europe in the second half of the $20^{\text {th }}$ century emerges as a success story. ${ }^{825}$ In 2005, Susanne Karstedt wrote: ${ }^{826}$

\begin{abstract}
None of the contemporaries who witnessed the end of World War Two, and saw the sheer scale of European calamity, would have dared to predict that only a decade later Western European economies would be thriving, and a union amongst the former enemies would have been forged in the Western parts of the continent. If anything else, this unique European experience demonstrates that peace and reconciliation are possible, even after the most horrific atrocities and unspeakable injustices, and even after two wars that had cost the lives of millions of European citizens within the lifetime of one generation, leaving nearly no family unaffected.
\end{abstract}

\footnotetext{
${ }^{822}$ Bassiouni, above n 4, 554; See also Stoltzfus and Friedlander, above n 119, 12.

${ }^{823}$ Ellis Washington The Nuremberg Trials: Last Tragedy of the Holocaust (University Press of America, Lanham, 2008) 125-127; See also Lord Hankey, who generally shared this view and described the trials as "a deplorable example to other nations, and especially to those with a relatively low standard of civilization and morality", but he also gave credit to the Allies that they achieved to a certain degree "the establishment of a rule of law among the nations that will operate in war no less than in peace." Lord Hankey "Postscript: A Political Commentary" in Viscount Frederic H Maugham U.N.O. and War Crimes (John Murray, London, 1951) 128-129.

${ }_{824}^{82}$ Washington, above $\mathrm{n} 823,125$.

${ }^{825}$ Susanne Karstedt "The Nuremberg Tribunal and German Society: International Justice and Local Judgment in Post-Conflict Reconstruction" in David A Blumenthal and Timothy L H McCormack (eds) The Legacy of Nuremberg: Civilising Influence or Institutionalised Vengeance? (Martinus Nijhoff Publishers, Leiden, 2008) 13.

${ }^{826}$ Ibid.
} 
Nevertheless, Washington has a point, though, and as a matter of fact, it is obvious that the Nuremberg Trials did not deter dictators and tyrants from breaking the rules of international law. However, it cannot be said that Nuremberg did more harm than good to society as Germany and Western Europe in the second half of the $20^{\text {th }}$ century experienced their most peaceful and prosperous time in history.

\section{Conclusion}

The Nuremberg Trials were not perfect, but they changed the world order in an impressive manner. The implementation of new criminal concepts, such as crimes against humanity and individual responsibility, and - specifically introduced in the Justice Trial - the rule that judges can be held responsible for their actions independent from what their national law says and the principle that crimes committed by national authorities against its own citizens may also be crimes under international law, established a completely new system of criminal law, under which we live today.

The transition from a system entirely premised on state sovereignty to a system which protects the human rights of individuals, is the biggest achievement in international law since the Peace of Westphalia in 1648.

Unfortunately, Nuremberg did not prevent new wars, conflicts and human rights violations, but nobody could have seriously expected this. In this context, the legacy of Nuremberg is not the prevention of such crimes but the clear signal that their perpetrators can never feel protected by law again.

The subsequent Nuremberg Trials, additionally, made clear that this applies not only to the leaders but to everybody who actively participates or supports such crimes. I agree with Telford Taylor, who stated in 1955: "The great question today is not whether the Nuremberg principles are valid, but 
whether mankind can live up to them, and whether it can live at all if it fails." 827

Regarding the achievements within the substantive law, the establishment of several international and national tribunals since the 1990s have shown that the Nuremberg ideas are more relevant than ever. For example, the doctrines established by the Justice Trial became an important factor within the legal processing of East Germany's past by German courts after the end of the East German state in $1990 .{ }^{828}$

Proceedings like the Wall-shooters' trials and the Perversion-ofjustice trials against East German soldiers, officials and judges were mainly based on the Nuremberg ideas of protecting fundamental human rights and holding individuals responsible for their actions, regardless of their hierarchical position in society. ${ }^{829}$

In summary, it has to be concluded that Nuremberg truly established a new international criminal law. The London Agreement with its annexed Charter and the following first Nuremberg Trial caused a complete turnaround of the existing world order towards the international recognition of human rights.

Additionally, the subsequent Nuremberg Trials, including the Justice Trial, refined these doctrines and established many precedents for later trials. Eventually, the legacy of these trials is best described by author Jonathan Friedman who stated: "[T]he subsequent trials gave the prosecution of war crimes a depth in legal theory and practice that heretofore did not exist." 830

\footnotetext{
${ }^{827}$ Taylor "The Nuremberg Trials", above n 15, 525.

${ }^{828}$ See generally Peschel-Gutzeit and Jenckel, above n 426, 287-295.

${ }^{829}$ Ibid.

${ }^{830}$ Friedman, above n 2, 95 .
} 


\section{B The Failure of the US War Crimes Trial Programme}

Based on the London Charter and Control Council Law No. 10, the four Allies convicted around 5,000 war criminals after World War II in their respective occupation zones. ${ }^{831}$. However, in the context of the estimated hundreds of thousands of potential German war criminals, these numbers are very small. ${ }^{832}$

With respect to the trials in the US zone, various authors take the view that the US war crimes trial programme failed in many ways. ${ }^{833}$ Mark Aarons, for example, stated as follows: ${ }^{834}$

As the Cold War sharpened, tensions between the former Allies in the second half of the 1940s, the effort to bring Nazis to justice wound slowly down and then ground to a complete halt in the early 1950s. At this time, Western efforts at denazification in Germany and trials of accused war criminals descended into farce, as the building of West Germany was found to be impossible without pardoning and releasing many convicted mass killers.

Indeed, the Nuremberg Justice Trial remained the only trial of the US authorities against members of the legal profession of Nazi Germany, ${ }^{835}$ and the convicted defendants were all released in the 1950s, long before the end of their original prison terms. ${ }^{836}$ Yet, the upcoming Cold War was a major but not the only reason for the failure of the US programme. The deep-rooted opposition from Germany's society, and the US amnesties, which were based on both political and legal reasons, were also important factors.

\footnotetext{
${ }^{831}$ The United States convicted 1,814 persons of whom 450 were executed, Great Britain 1,085 with 240 executed, France 2,107 with 109 persons executed, and the Soviet Union tried and executed an unknown number of persons. Bassiouni, above n 4, 532.

${ }^{832}$ Friedman, above n 2, 95.

${ }^{833}$ See generally Buscher, above n 72, 159-164; Stoltzfus and Friedlander, above n 119, 1 13; Friedman, above n 2, 91-95; Clark and Lediakh, above n 298, 275-280.

${ }^{834}$ Aarons, above $\mathrm{n} 397,76$.

${ }^{835}$ Baestlein, above n 12, 9; Heribert Ostendorf "Politische Strafjustiz vor und nach 1945" (1999) 248 Informationen zur politischen Bildung 1, 7.

${ }^{836}$ Mueller, above n 120, 273.
} 
When looking at the core question of this paper, the uniqueness of the Justice Trial and the early release of the convicts from prison seem only beneficial for the vanquished Germans, but then it has to be asked whether this was an arbitrary exercise of power by the US Government and, therefore, an example of victor's justice.

It will be shown that different factors of a political and legal nature caused these results and, in the end, the former US authorities can be exonerated from the accusation that victor's justice had occurred.

\section{The upcoming Cold War}

Political and ideological differences between the Western Allies and the Soviet Union were put aside during World War II to defeat the German armed forces in a joint effort. Nevertheless, after the war was won, these differences soon started to become insurmountable obstacles in the relationship between the former Allies.

Additionally, several occurrences in the second half of the 1940s created a hostile atmosphere especially between the United States and the Soviet Union, which finally culminated in the Cold $\mathrm{War}^{837}$ which dominated the world until the end of Communism in Eastern Europe in the early 1990s. In respect of the US war crimes trial programme, Friedman summarised these post-war developments as follows: ${ }^{838}$

\footnotetext{
From the first trial session in October 1946 to the last review in December 1949, the world had witnessed an escalating series of confrontations between the Western Allies and the Soviet Union, among them the
}

\footnotetext{
${ }^{837}$ The term Cold War stands for "the open yet restricted rivalry that developed after World War II between the United States and the Soviet Union and their respective allies. The Cold War was waged on political, economic, and propaganda fronts and had only limited recourse to weapons. ... Throughout the Cold War the United States and the Soviet Union avoided direct military confrontation in Europe and engaged in actual combat operations only to keep allies from defecting to the other side or to overthrow them after they had done so. ... In late 1991 the Soviet Union collapsed and ... [t]he Cold War had come to an end." “Cold War" www.britannica.com (last accessed 19 March 2010).

${ }^{838}$ Friedman, above n 2, 91 .
} 
Communist incursion into southeastern Europe and central Asia before 1947, which inspired the Truman Doctrine $\left[{ }^{839}\right]$; the Communist coup in Czechoslovakia in March 1948; the promulgation of the Marshall Plan $\left[{ }^{840}\right]$ one month later; the Berlin Blockade $\left[{ }^{841}\right]$ in the summer of that year; the founding of the North Atlantic Treaty Organization on 4 April 1949; the founding of the West German Federal Republic in May; the Soviets' detonation of a nuclear weapon in September 1949; and the creation of the communist German Democratic Republic (GDR) on 7

October.

Naturally, these occurrences strongly influenced the US policy towards Germany and, according to Friedman, "[a]s a result ... of this intensifying conflict, American policy toward Germany shifted from one of occupation and denazification ... to one of reconstruction and integration" ${ }^{\prime 42}$.

Fearing that Communism could become the dominant political system all over Europe, the United States, together with their Allies Britain and France, decided early to rebuild and strengthen the area of Western Europe as a bulwark against Communism. ${ }^{843}$ The decision to establish a

\footnotetext{
${ }^{839}$ The Truman Doctrine generally describes the Cold War strategy of containment of the United States versus the Soviet Union and the expansion of Communism, established by President Harry S Truman in March 1947, after he had declared immediate economic and military aid to the governments of Greece and Turkey, which had become targets on Communist insurrection and Soviet expansion in the Mediterranean area. "Truman Doctrine" www.britannica.com (last accessed 19 March 2010).

${ }^{840}$ The Marshall Plan was the "U.S.-sponsored programme designed to rehabilitate the economies of 17 western and southern European countries in order to create stable conditions in which democratic institutions could survive." Established by the Truman Government, some 13 billion dollars worth of economic aid, helping to restore industrial and agricultural production, establish financial stability, and expand trade, were distributed between April 1948 and December 1951, leading to a strong European economy in the 1950s. "Marshall Plan” www.britannica.com (last accessed 19 March 2010).

${ }^{841}$ The Berlin Blockade was an "international crisis that arose from an attempt by the Soviet Union, in 1948-1949, to force the Western Allied powers ... to abandon their postWorld War II jurisdictions in West Berlin. ... [T] he Soviet occupation forces in eastern Germany began a blockade of all rail, road, and water communications between Berlin and the West. ... On June 26 [1948] the United States and Britain began to supply the city with food and other vital supplies by air. ... [T] $]$ he airlift kept life going in West Berlin for 11 months, until on May 12, 1949, the Soviet Union lifted the blockade." "Berlin Blockade and Airlift" www.britannica.com (last accessed 19 March 2010).

${ }^{842}$ Friedman, above n 2, 91-92.

${ }^{843}$ Buscher, above n 72, 56, 70.
} 
new West German republic on the territory of the former occupation zones of the three Western Allies was the clearest sign of this new policy. ${ }^{844}$

In return, East Germany was founded as a Communist state under the influence of the Soviet Union on the territory of its former zone of occupation, and this established the Cold War as the new world order for the next 40 years.

The newly founded Federal Republic of West Germany was the closest neighbour of the new Communist countries of Eastern Europe and, therefore, became very important as an ally of the US and of the Western Europe defence community. ${ }^{845}$ To protect the Western world from Communism, a German contribution to the defence of the West was desperately needed and, to achieve this support, the Western Allies were aware that they "would have to pay for this by restoring the sovereignty of Germany.",846

Additionally, the creation of an East German paramilitary force in 1949, and the outbreak of the Korean War in June 1950 as the first proxy war of the Cold War conflict between the United States and the Soviet Union, put the question of Germany's rearmament on the map. ${ }^{847}$

In this situation, the Allied scheme to prosecute and punish German war criminals turned from a programme into a problem. The imprisoned war criminals became an uncomfortable burden to both the Allied and the West German Governments on the path to make West Germany an equal partner militarily and politically. ${ }^{848}$ Although criticised before, the US war crimes trial programme now became the target of many attacks from legal experts and powerful political groups in both German and American society, including the US Congress and the new West German Parliament. ${ }^{849}$

\footnotetext{
${ }^{844}$ Ibid, 56.

${ }^{845}$ Ibid, 3.

${ }^{846}$ Ibid, 70.

${ }^{847}$ Ibid.

848 Ibid.

${ }^{849}$ Friedman, above n 2, 91; Buscher, above n 72, 55, 92, 115.
} 
Consequently, beginning in 1951, the focus of the US authorities was no longer on punishing war criminals and re-educating the German public, but rather on preventing the war criminals problem from causing further controversy in both the United States and Germany. ${ }^{850}$ As a result, no more trials were held under US tribunals, and clemency and sentence modification procedures were introduced for those Germans who had been already convicted and imprisoned. ${ }^{851}$

With this new war criminals policy the way was cleared for the realisation of the political visions of the Western Allies and, in 1955, West Germany actually became sovereign and joined the North Atlantic Treaty Organisation (NATO) with its own national army. ${ }^{852}$

Yet, the Western Allies had to pay a high price for these achievements, which is best summarised by Frank M Buscher who stated: "The decision to promote German participation in the defense of Western Europe led to the dismantling of the war crimes program."

\section{The resistance of Germany's post-war judiciary}

When the US authorities designed their war crimes trial programme, they had in mind that the subsequent Nuremberg Trials shall also serve as examples for further trials conducted by German post-war courts under Control Council Law No. $10{ }^{854}$ Yet, they underestimated that Germany's post-war judiciary "was embedded within a society whose members had, by and large, consented to the Nazi dictatorship." ${ }^{855}$

\footnotetext{
${ }^{850}$ Buscher, above n 72, 3 .

851 Ibid.

${ }^{852}$ Ibid, 71 .

853 Ibid, 70.

${ }^{854}$ Ibid, 2; Doerte Hinrichs and Hans Rubinich "Von Hitler zu Adenauer" (29 November 2007) Die Zeit Hamburg (Germany) www.zeit.de (last accessed 19 March 2010); See also Taylor Final Report, above n 169, 16, 95, 101, 106.

${ }^{855}$ Stoltzfus and Friedlander, above n 119, 8; See also Part II A 2 (b) (iii) Evaluation and Part II B The Moral Necessity of the Trial.
} 
Nevertheless, in the beginning, the US war crimes trial programme seemed promising as many Germans showed interest and had a generally positive opinion about the conduct of trials against Nazi perpetrators. ${ }^{856}$ This basic attitude changed in 1947, when the denazification programme of the Allies reached its peak and millions of Germans suddenly imagined themselves in the dock. ${ }^{857}$

Guided by the popular motto of Schlussstrich ziehen (drawing the final line under the Nazi past) in the 1950s in post-war Germany, the war crimes trials became opposed by many leading institutions of the West German society, including the first government, almost all political parties, the Catholic and Protestant churches, many legal experts and veterans and refugee organisations. ${ }^{858}$

Their arguments were based on different reasons and varied from legal ones, such as that the Nuremberg sentences "had relied on ex post facto law" ${ }^{, 59}$, to political ones, such as the claim that "a German contribution to Western defence would be impossible if the Americans insisted on executing the remaining Landsberg $\left[{ }^{860}\right]$ death row inmates" ${ }^{\text {"861 }}$, to moral ones, such as that the war crimes trials were "a direct attack on the honour of the German soldier ... whose only crime was that they had fulfilled their orders."

In this atmosphere, the German post-war judiciary was no exception and opposed the war crimes trial programme in its own way. Although German post-war judges had managed to sentence around 4.500 Nazi criminals under Control Council Law No. 10 until the end of $1952,{ }^{863}$ members of their own profession were not among them. ${ }^{864}$ This situation

\footnotetext{
${ }^{856}$ Baestlein, above n 12, 27; Kastner "Der Dolch des Moerders war unter der Robe des Juristen verborgen: Der Nuernberger Juristen-Prozess 1947”, above n 317, 703.

${ }^{857}$ Baestlein, above n 12, 27; See also Part III C The Defendants.

${ }^{858}$ Buscher, above n 72, 3, 92, 115, 162.

${ }^{859}$ Ibid, 93.

860 Landsberg (US), Wittlich (France) and Werl (Britain) were the three prisons in Germany, where the Western Allies locked up their convicted German war criminals. Ibid, 56.

${ }^{861}$ Ibid, 71; See also Part VI B 1 The upcoming Cold War.

${ }^{862}$ Buscher, above n 72, 107, 163.

${ }^{863}$ Baestlein, above n 12, 29.

${ }^{864}$ Mueller, above n 120, 274.
} 
changed for the better when a new generation of German jurists entered offices in the 1960s and 1970s, but even then, the amount of indictments against Nazi judges and prosecutors was all too small compared to the amount of crimes committed in the name of law during the Nazi era. ${ }^{865}$

Additionally, Germany's post-war judiciary tended to accept court rulings issued during the Nazi period as valid. ${ }^{866}$ Although a total of approximately 90,000 investigations were carried out against Nazi criminals in the area of Western Germany, only 6,500 persons were finally convicted. ${ }^{867}$ Also, it is a devastating fact that - apart from two exceptions regarding judges of courts martial in the closing phase of the war - no German judge, prosecutor, or legal official was finally convicted by a German post-war court for his actions during the Nazi era. ${ }^{868}$

Furthermore, in the small number of trials against former Nazi jurists, the reasons for the acquittals given by the German courts were most of the time outrageous. For example, the Kassel County Court decided in a case against a Nazi Special Court judge that "because of the judges' fanaticism, 'the possibility of blindness to injustice, based on political delusions ... cannot be excluded.' The verdict was therefore 'not guilty." "\$69

The Federal Supreme Court of West Germany adopted the permanent view of legal scholars and officials that "a judge could be found guilty of murder, manslaughter, or false imprisonment only if it could be proved that he had knowingly broken the law." ${ }^{870}$ In most of the cases, this was exactly what could not be proved and, therefore, led to the acquittal of the defendants. ${ }^{871}$

The most prominent example of these embarrassing verdicts is the case of Hans-Joachim Rehse, who was the most culpable judge of the Nazi

\footnotetext{
${ }^{865}$ See generally Ibid, 274-283.

${ }^{866}$ Stoltzfus and Friedlander, above n 119, 7-8.

${ }^{867}$ Karstedt, above n 825, 32 .

${ }^{868}$ Baestlein, above n 12, 33; See also Ostendorf, above n 835, 7; Mueller, above n 120, 274.

${ }^{869}$ Mueller, above n 120, 277.

${ }^{870}$ Ibid, 276; See also Ostendorf, above n 835, 8.

${ }^{871}$ Ostendorf, above n 835,8 .
} 
People's Court besides Roland Freisler. ${ }^{872}$ After the Berlin County Court had found Rehse guilty of aiding and abetting murder and had sentenced him to five years imprisonment in 1967, refusing the defendants' argument of blindness to injustice as a valid defence, the case was appealed and brought to the Federal Supreme Court. ${ }^{873}$

Its judges claimed to see "obscurities and contradictions" $" 874$, quashed the verdict and handed down the case to the County Court with the undisguised recommendation to find for acquittal. ${ }^{875}$ In the end, a new jury at the Berlin County Court acquitted not only Rehse but, according to Ingo Mueller, "in effect the entire Nazi People's Court and the entire Nazi judicial system."

When looking at the numbers of jurists who served under the Nazi Government and maintained or regained their jobs in the West German judicial system, these judgments are not surprising. True to the motto Schlussstrich ziehen, the new German Parliament and Government did everything they could to rehabilitate not only former Nazi jurists but almost all members of the elites of German society who had been involved in Nazi crimes. $^{877}$

Based on Article 131 of the new German Basic Law of 1949, which provided that federal laws shall regulate the rights of persons "who on 8 May 1945 were employed in the public service ... and have not yet been reinstated or are employed in positions that do not correspond to those they previously held" ${ }^{878}$, the German Parliament enacted several laws which

\footnotetext{
${ }^{872}$ Mueller, above n 120, 280; See also generally Robert M W Kempner Anklaeger einer Epoche: Lebenserinnerungen (Ullstein Verlag, Frankfurt/Main, 1986) 423-425.

${ }^{873}$ Mueller, above n 120, 280-281.

${ }^{874}$ Ibid, 281.

${ }^{875}$ Ibid; See also generally Urteil des Bundesgerichtshofs vom 30. April 1968 (Judgment of the German Federal Supreme Court (BGH) from 30 April 1968) 21 NJW 1339 (BGH -5 StR 670/67-).

${ }^{876}$ Mueller, above n 120, 281.

${ }^{877}$ Christian Staas "Was damals Recht war ..." (25 February 2009) Die Zeit Hamburg (Germany) www.zeit.de (last accessed 19 March 2010).

${ }^{878}$ Basic Law for the Federal Republic of Germany 1949 (as amended up to June 2008), art
} 131. 
finally led to the reemployment of almost all judges and prosecutors of the Nazi judiciary in the new West German judicial system by the mid 1950s. ${ }^{879}$

As a result, the West German judiciary became dominated by jurists who had been part of the Nazi judicial system and were, at least to a certain degree, jointly responsible for the terrors of the Nazis. ${ }^{880}$ Some authors went as far as saying that the West German judiciary became re-nazificated. ${ }^{881}$

However, according to many legal experts and historians, the obvious resistance of Germany's post-war judiciary to deal with its own past can be explained not only by self-justification of potential perpetrators. ${ }^{882}$ Also, the traditionally conservative world view of members of the legal profession, which implies that judges in any time have to act neutrally and have to apply the given laws to protect law and order within a state, is seen as an important factor. ${ }^{883}$

Consequently, there was a true belief - even by many judges who had not been part of the Nazi legal system or were born afterwards - that most of the judges of the Nazi era were innocent, and only the political leaders and legislators of Nazi Germany could be held responsible for the committed cruelties. ${ }^{884}$

As late as 1995, the Federal Supreme Court of Germany corrected its previous jurisdiction concerning Nazi perpetrators, admitted the failure of the West German judiciary in coming to terms with its own past and particularly expressed its regret over its past decisions in regard to the Nazi jurisdiction. ${ }^{885}$ Additionally, the German Parliament, in 1999, officially

\footnotetext{
${ }^{879}$ Mueller, above n 120, 205-206; See also Staas, above n 877; Hinrichs and Rubinich, above n 854; Ostendorf, above n 835, 8; Volker Friedrich Drecktrah "Der Versuch aus der Vergangenheit zu lernen, ist nicht ganz gescheitert" (2003) 11 Neue Justiz 578, 580.

880 Staas, above n 877; Hinrichs and Rubinich, above n 854; Ostendorf, above n 835, 8; Drecktrah, above n 879, 580; Baestlein, above n 12, 34 .

${ }^{881}$ Drecktrah, above n 879, 580.

882 Ibid; Kramer "Richter vor Gericht: Die juristische Aufarbeitung der Sondergerichtsbarkeit”, above n 342, 166-168.

883 Ibid.

${ }^{884}$ Kramer "Richter vor Gericht: Die juristische Aufarbeitung der Sondergerichtsbarkeit", above n 342, 168.

885 Ibid, 170; Drecktrah, above n 879, 578, 580; See also generally Urteil des Bundesgerichtshofs vom 16. November 1995 (Judgment of the German Federal Supreme Court (BGH) from 16 November 1995) 41 BGHSt 317 (BGH -5 StR 747/94-).
} 
declared the unjust judgments of the Nazi era illegal. ${ }^{886}$ This was an important symbolic sign, but too late for consequences as the vast majority of Nazi jurists was not alive anymore.

In the end, it remains that the US authorities had the good idea of help for self-help but underestimated the unwillingness of Germany's postwar society, and especially its judiciary, to face up to the past.

\section{The amnesties of the 1950s}

The convicted defendants in the Justice Trial were sentenced by a purely US tribunal. Therefore, they took their chances to file writs of habeas corpus to the US Supreme Court, who denied them in all cases by order of 2 May 1949. ${ }^{887}$ However, this was not the end of the story as the convicts were able to benefit from US parole and clemency programmes in the 1950 s. $^{888}$

When the Office of the US High Commissioner for Germany (HICOG) was established on 6 June 1949, the Military Government of the US zone of occupation in Germany officially ended. ${ }^{889}$ Military Governor General Lucius Clay was succeeded by the first High Commissioner, former Assistant Secretary of War John J McCloy, who also took over the responsibility for the execution and review of sentences against the convicts of the 12 subsequent Nuremberg Trials. ${ }^{890}$

Clay had reduced sentences in only three cases from the trials, but this changed dramatically under McCloy. ${ }^{891}$ As a response to pressure from German and American political leaders, ${ }^{892}$ McCloy established a clemency

\footnotetext{
${ }^{886}$ Staas, above n 877.

${ }^{887}$ Justice Case, above n 9, 1204.

${ }^{888}$ Buscher, above n 72, 31 .

${ }^{889}$ Friedman, above n 2, 89.

${ }^{890}$ Ibid, 88-89; Buscher, above n 72, 57.

${ }^{891}$ Friedman, above n 2, 89, 93.

${ }^{892}$ See Part VI B 1 The upcoming Cold War and Part VI B 2 The resistance of Germany's post-war judiciary.
} 
review board in November $1949 .{ }^{893}$ After a quick review, the board recommended the reduction of sentences or immediate clemency in several cases and, on 31 January 1951, McCloy announced that "of the 101 convicted war criminals held in Landsberg prison, 33 were to be released immediately, an additional 35 were to have their sentences reduced, and 16 death sentences were to be commuted." 894

These orders applied to all convicts of the Justice Trial, who were imprisoned at the US prison for war criminals in Landsberg. Due to illness, Schlegelberger had been released from prison in 1950 already, but all others - except for Rothaug, whose sentence was commuted to 20 years imprisonment - were at liberty again in $1951 .^{895}$ Other amnesties followed and led also to the release of Rothaug in $1956 .{ }^{896}$

During the early and mid 1950s, not only the US but the British and French authorities as well granted "amnesty to almost all the Nazi criminals they had previously sentenced." $" 897$ One of the prosecutors at the first Nuremberg Trial and a leading expert within the area of Nazi crimes, Robert M W Kempner, described this policy of the Western Allies as a "pardoning fever" ${ }^{\prime 898}$.

Indeed, from 3,643 German war criminals held in custody of the Western Allies and other foreign countries on 1 April 1950, only 1,033 persons were still imprisoned on 25 August $1952 .{ }^{899}$ The prison population in Landsberg (US) became reduced from 663 to 338, in Werl (Britain) from 379 to 132 and in Wittlich (France) from 273 to $105 .{ }^{900}$ By May 1955, only fifty prisoners remained at Landsberg, ${ }^{901}$ and in 1957, Britain and France

\footnotetext{
${ }^{893}$ Friedman, above n 2, 93.

${ }^{894}$ Ibid.

${ }^{895}$ Mueller, above n 120, 273; Baestlein, above n 12, 29-31.

${ }^{896}$ Mueller, above n 120, 273; Baestlein, above n 12, 31.

${ }^{897}$ Mueller, above n 120, 243.

${ }^{898}$ Ibid.

${ }^{899}$ Buscher, above n 72, 171.

${ }^{900}$ Ibid.

${ }^{901}$ Ibid, 4.
} 
closed their prisons for war criminals at Werl and Wittlich, followed by the US prison at Landsberg in $1958 .^{902}$

Simultaneously, the Parliament of the new West German Federal Republic passed legislation, which granted amnesties to thousands of potential German war criminals. ${ }^{903}$ As one of the first laws passed by the new parliament, a general amnesty was granted "for all crimes committed during the Nazi era with a maximum penalty of one year in prison or less." 904 . Additionally, amnesty was granted to "anyone who had 'disguised his identity for political reasons' by forging documents or giving false information." $" 905$

In 1954, this legislation was even extended to cover ${ }^{906}$

all crimes that had maximum sentences of up to three years and that had been committed 'under the influence of the unusual circumstances of the collapse between October 1, 1944, and July 31, 1945, while carrying out an official or legal duty, particularly an order'.

Also, the law provided that "[p]enalties imposed by de-Nazification boards immediately after the war were erased from the criminal records" ${ }^{\$ 907}$, allowing Nazi criminals to rejoin the public service and enter leading positions in Germany again easily. ${ }^{908}$

At first sight, the reasons for all these amnesties are based on the political situation. The upcoming Cold War and the need of a West German contribution to the defence of the Western world strengthened the German Government and weakened the Allies in regard to the war criminals issue. ${ }^{909}$ Nevertheless, the political situation was not the only matter that caused the US amnesties.

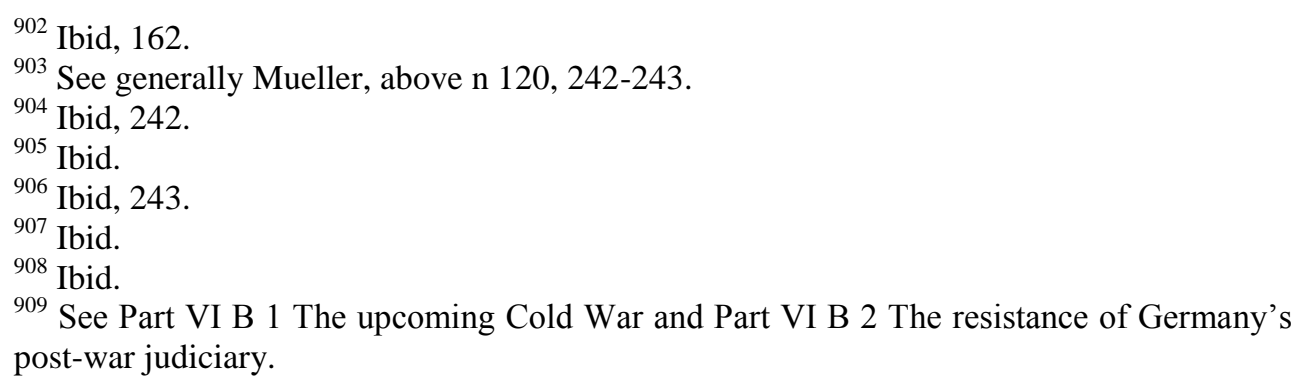


The lack of any planning for an appellate court and the fact that the accused could not appeal the judgments and the verdicts of the US tribunals made the US authorities feel uncomfortable from the beginning. ${ }^{910}$ Therefore, they began to address these questions as early as 1946 with the result that "[e]xecutive clemency and regular administrative sentence reviews became substitutes for an appellate court."911

It allowed US officials to ensure that equal offences would be punished evenly, which had not always been the case, especially when one compares the grade of judgments in the trials at the beginning (more severe) and the trials at the end (more lenient). ${ }^{912}$ As a result, from a purely legal point of view, the clemency programmes truly created a good balance between the different decisions of the trials. ${ }^{913}$

\section{Conclusion}

A combination of political and legal reasons led to the dismantling of the US war crimes trial programme. The increasing conflict between East and West and the vehement resistance of leading parts of West German society including all the judiciary, led to a sudden stop of the prosecution of more German war criminals by US authorities.

In addition with the legal problem of the absence of an appellate court, these factors also led to the large-scale US amnesties, from which not only the convicts of the Justice Trial but many other Nazi war criminals benefited. These facts, however, do not qualify the Justice Trial as an example of victor's justice.

At the time of the trial, in 1947, the US authorities did not plan to stop their war crimes trial programme just a few years later. They also had

\footnotetext{
${ }^{910}$ Buscher, above n 72, 22; See also Part IV B Fairness of the Trial.

${ }^{911}$ Buscher, above n 72, 22.

912 Ibid; See also Part V B 2 The Tribunal's relatively mild sentencing.

${ }^{913}$ See generally Whitney R Harris, above n 18, 546-554.
} 
in mind that a new German post-war judiciary would continue the work of the US tribunals and would try war criminals under Control Council Law No. 10. It was not foreseeable at the time that the attitude of Germany's society towards the prosecution of war criminals would change from support to opposition, and that dramatic developments in international politics would occur in the late 1940s.

Furthermore, nobody could expect that West Germany's new judiciary would ignore the jurisdiction of the Nuremberg Trials for decades and would resist sentencing Nazi criminals to a large extent. One maybe asks then why the US authorities did not continue their war crimes trial programme themselves.

After it had become clear that a German contribution to the defence of Western Europe was needed, West Germany's position in its relationship with the Western Allies grew strong. To continue prosecuting German war criminals on their own would have created the risk for the US authorities of losing an important ally in the new confrontation with Communism and was, therefore, not a realistic option.

As a result, only a tiny minority of the tens of thousands of war criminals from the Nazi era was finally convicted, and the defendants in the Justice Trial remained - besides very few exceptions - the only members of the legal profession of Nazi Germany who stood trial for their actions. Nevertheless, the global political conditions of the late 1940s justify the uniqueness of the Justice Trial and exculpate the US authorities from the accusation that the trial was only an example of victor's justice.

The early release of the convicts of the Justice Trial from prison in 1951 and 1956, caused by generous amnesties of the US High Commissioner, can also not be evaluated as an example of victor's justice. Victor's justice, here, does not refer to any disadvantages of the German defendants as the amnesties were obviously only for the benefit of the convicts, but to the question whether the US authorities exercised their power as the winners of the war in an arbitrary way. 
The necessary change of US policy towards West Germany from occupation and denazification to reconstruction and integration, let both American and German politicians put immense pressure on the US authorities responsible for the imprisoned war criminals to find a quick and practical solution.

Additionally, the legal problem of having no appellate court made it necessary to run extensive clemency programmes. These were important reasons for the amnesties and, although the lenient results were a slap in the face for Nazi victims and for those who were aware of the committed crimes, it cannot be said that the US authorities used their power in an arbitrary manner.

Obviously, the war criminals issue was heavily influenced by political decisions, but this should not necessarily be evaluated as negative because law is always strongly connected with politics. Without the Nazi policy, the German law system would have never been transformed into an instrument of terror, and without the decisions of the US Government in favour of trials, the German war criminals would probably have just been shot.

Political decisions, therefore, need to be evaluated carefully. The Nazi policy for the change of the German judicial system was without doubt arbitrary, based on a mad ideology of racism and conquest. The US policy in regard to its own war crimes trials programme, in contrast, was based on understandable reasons. Surely, it would have been possible for the US authorities to maintain the programme in favour of moral and ethical values, but the given circumstances demanded a change.

As a result, the US officials may be criticised for choosing the easiest way but, as shown above, it was definitely for a comprehensible reason. Hence, in my view, the United States used their power not arbitrarily and, therefore, the amnesties cannot be evaluated as an example of victor's justice. 
However, the small number of convictions of Nazi perpetrators, and the full re-integration of most Nazi jurists in West Germany's society, caused the overall failure of the US war crimes trial programme, which casts a shadow over the legacy of the Justice Trial. Yet, its legacy is still extraordinary.

Besides the establishment of new principles and rules in international criminal law, the Justice Trial, together with the other Nuremberg Trials, became "the world's first post mortem examination of a totalitarian regime" ${ }^{914}$, and resulted in a unique record of the Nazi judicial system and the involvement of its members in Nazi crimes. ${ }^{915}$

It has to be asked whether Germany's judiciary today, known as independent and generally fair, would be the same without this knowledge, especially when considering the Schlussstrich mentality of Germany's society in the 1950 s.

\footnotetext{
914 Taylor "The Nuremberg Trials", above n 15, 522.
}

${ }^{915}$ See Part IV B Fairness of the Trial. 


\title{
VII CONCLUSION
}

At the end of World War II, Hans Morgenthau, known as the father of American realism, said: ${ }^{916}$

\begin{abstract}
I am doubtful of the whole setup under which these [Nuremberg] trials will be conducted. What, in my opinion, they should have done is to set up summary courts-martial. Then they should have placed these criminals on trial before them within 24 hours after they were caught, sentenced them to death, and shot them in the morning.
\end{abstract}

To realists, "a war crimes tribunal is simply something that the countries that decisively win a war inflict on the helpless country that loses it. It is punishment, revenge, spectacle - anything but justice."917 Accordingly, Morgenthau's statement implied the concern that the Nuremberg Trials would be nothing else but examples of victor's justice and, therefore, would be without any value for international law and society.

Before the trials, there was good reason for such concern, because the dimension of atrocities committed by Nazi Germany established a cry for vengeance which could not be ignored by the organisers of the trials. However, in the end, the trials have to be seen as generally fair, and they set important precedents for international criminal law.

This work focused on the third of the subsequent Nuremberg Trials, the Justice Trial, which is a fascinating one not only because Hollywood used it as the basis for the Academy Award winning movie Judgment at Nuremberg, but because here, for one of the only times in history, men were put on trial who acted in the name of existing domestic law.

The question whether these men were tried and - some of them convicted in accordance with international law and approved rules and principles of due process or were just victims of victor's justice is the core

\footnotetext{
916 Bass, above n 21, 10.

${ }^{917}$ Ibid, 11.
} 
and overall question of this thesis. The term victor's justice describes a special form of vengeance, exercised behind a smokescreen of legality in a judicial proceeding, which in fact, is nothing else but a show trial.

The paper has analysed and evaluated all areas of the Justice Trial in relation to the concept of victor's justice: from the creation of the legal basis, to the proceedings and judgments during, to the enforcement of the sentences after the trial. In most areas, there were no convincing examples of victor's justice.

However, two issues have to be regarded as examples of victor's justice: firstly, the violation of the principle of separation of powers by establishing a court which ruled under international law but had only nationals of the United States as members of the Tribunal and the prosecution; and secondly, the refusal of the US authorities to try members of their own armed forces for crimes similar to some of the crimes the defendants were charged with and which were defined in the London Charter and Control Council Law No. 10 (te quoque argument).

On the other hand, popular accusations, such as the violation of Germany's state sovereignty, the lack of impartiality of the judges, the violation of the ex post facto principle, the illegal introduction of individual responsibility and the denial of a fair trial, could not be approved as examples of victor's justice:

The passing of legislation by the Allies for and the establishment of Allied tribunals on German territory immediately after World War II did not violate Germany's state sovereignty because, from a practical point of view, a German state did not exist anymore. The unconditional surrender of Germany had not only ended the war, it had ended National Socialism which had infiltrated all areas of life in Germany so deeply that its end caused the complete collapse of German society.

Furthermore, German courts and judges were not trustworthy at the time, and by dropping the conspiracy charge of the indictment, the 
appointed US judges of Military Tribunal III proved that they acted impartially and independently.

Also, the introduction of new concepts such as crimes against humanity and individual liability did not violate international law. The ex post facto principle had to step back in favour of its original aim, the creation of justice, because the defendants were aware of the criminality of their actions at any time. The same reason apply to individual responsibility as the defendants knew that they were doing wrong, and therefore, could not expect to go unpunished. Additionally, the unprecedented variety and dimension of Nazi crimes, which injured the whole international community and shocked the conscience of humankind, required a change of traditional international criminal law away from the Acts of State doctrine towards individual responsibility.

With respect to the principles of due process, the Justice Trial fulfilled all requirements of a fair trial and disproved the accusation of being a show trial, because the defendants were charged with punishable crimes, they had full opportunity for defence, including free access of their lawyers to captured documents and exhibits, and they were judged fairly on the evidence by a proper court.

Additionally, victor's justice did also not occur from a moral point of view, because the amount and variety of unprecedented atrocities committed by Nazi Germany and the involvement of the German judiciary in it needed a significant response. Likewise, the selection of the defendants by the prosecution as well as the analysis and evaluation of the Nazi legal system and of the individual role of the defendants in Nazi Germany by Tribunal III showed no signs of victor's justice, as both acted with great care and in an unbiased manner.

Further, this paper analysed the questions of how suitably qualified the judges and prosecutors were, why the final sentences were relatively mild and why the defendants were all released early from prison in the 1950s. The idea here was to find out whether the Tribunal and the US authorities acted arbitrarily or whether these decisions were based on 
understandable reasons. Several reasons of practical, political and moral nature were given and, therefore, exculpated the members of the Tribunal as well as the US officials from the accusation of victor's justice in relation to these issues.

In the end, only two aspects can be seen as examples of victor's justice. The Justice Trial cannot be evaluated without considering them but, in the overall context, it would be wrong to draw the conclusion that the trial, therefore, was an occurrence of victor's justice. As shown in the respective chapter above, the achievements of the trial for international criminal law are of high value and, although limited by the overall failure of the US war crimes trial programme, the trials' legacy is a primarily positive one.

Many legal experts were convinced before and during the 13 Nuremberg Trials that the trials would be nothing else but show trials and examples of victor's justice. In the end, they were proved wrong and, although several aspects of the trials, such as the question whether the ex post facto principle was violated, remain controversial, the vast majority of legal experts today agree that Nuremberg was characterised by exemplarily fair proceedings and set remarkable precedents for international law. ${ }^{918}$

When looking at the incredible atrocities committed by Nazi Germany between 1933 and 1945, it is impressive and remarkable how the Allied victors, excepting the show trials and the arbitrary handling of prisoners of war by the Soviet Union, ${ }^{919}$ dealt with the German perpetrators. The result was not only a more or less fair handling of the vanquished Germans, but also the creation of a unique basis for a new international criminal law.

To quote the impressive words of the Chief Prosecutor for the United States, Robert H Jackson, which he made in his opening statement for the

\footnotetext{
918 See for example Bassiouni, above n 4, 554; Baestlein, above n 12, 34; Stoltzfus and Friedlander, above n 119, 6.

919 Kastner "Der Nuernberger Prozess", above n 148, 805; See also Bassiouni, above n 4, 532.
} 
prosecution in the trial against the major war criminals before the International Military Tribunal on 21 November 1945: ${ }^{920}$

The wrongs which we seek to condemn and punish have been so calculated, so malignant and so devastating, that civilization cannot tolerate their being ignored because it cannot survive their being repeated. That four great nations, flushed with victory and stung with injury stay the hand of vengeance and voluntarily submit their captive enemies to the judgment of the law is one of the most significant tributes that Power has ever paid to Reason. ...

Unfortunately, the nature of these crimes is such that both prosecution and judgment must be by victor nations over vanquished foes. The worldwide scope of the aggressions carried out by these men has left but few real neutrals. Either the victors must judge the vanquished or we must leave the defeated to judge themselves. After the first World War, we learned the futility of the latter course. The former high station of these defendants, the notoriety of their acts, and their adaptability of their conduct to provoke retaliation make it hard to distinguish between the demand for a just and measured retribution, and the unthinking cry for vengeance which arises from the anguish of war. It is our task, so far as humanly possible, to draw the line between the two. We must never forget that the record on which we judge these defendants today is the record on which history will judge us tomorrow. To pass these defendants a poisoned chalice is to put it to our own lips as well. We must summon such detachment and intellectual integrity to our task that this Trial will commend itself to posterity as fulfilling humanity's aspirations to do justice. ...

These defendants may be hard pressed but they are not ill used. ... If these men are the first war leaders of a defeated nation to be prosecuted in the name of the law, they are also the first to be given a chance to plead for their lives in the name of the law. Realistically, the Charter of this Tribunal, which gives them a hearing, is also the source of their only hope. It may be that these men of troubled conscience, whose only wish is that the world forget them, do not regard a trial as a favour. But they do have a fair opportunity to defend themselves - a favour which these men, when in power, rarely extended to their fellow countrymen. Despite the fact that public opinion already condemns their acts, we agree that here they must be given a presumption of innocence, and we accept the burden

${ }^{920}$ International Military Tribunal II, above n 472, 98-102. 
of proving criminal acts and the responsibility of these defendants for their commission.

The defendants in the Justice Trial received all benefits of a real trial, including an independent judiciary, the possibility of acquittal, fair proceedings and some kind of proportionality in sentencing. ${ }^{921}$ Thus, there can be no doubt that those defendants, who were found guilty, deserved their sentences, because they committed crimes which could not and should never go unpunished under international law.

\section{According to Professor Harry Reicher, ${ }^{922}$}

Law is inherently neutral. If it is used with wisdom and compassion, it can accomplish the greatest good. But if a legal system falls into the wrong hands, it can become the instrument of the greatest barbarities.

These wrong hands were not only Hitler's. Besides some leading Nazi jurists, they also belonged to many thousands of judges, prosecutors and other members of the German judicial system, who stayed in office after the Nazis took over power and who applied the new Nazi laws without any sense of shame. The defendants in the dock sat as representatives for all these German jurists. Although the defendants could and were made responsible for their individual guilt only, morally, the whole German judiciary was also indicted at the Justice Trial.

As correctly analysed by US Military Tribunal III, the German judicial system was transformed into an instrument of the Nazi Party soon after 1933 with the willing help and support of the vast majority of German jurists. ${ }^{923}$ Telford Taylor stated in 1949: ${ }^{924}$

The very nature of the Third Reich was totally incompatible with any 'law' worthy of the name, and German jurists bore a heavy share of the blame, both for what they did and what they failed to oppose, for the excesses of the dictatorship.

\footnotetext{
${ }^{921}$ See generally for these requirements of a bona fide trial Bass, above $\mathrm{n} 21,16$.

${ }^{922}$ Reicher "An Infamous Date: Nazi Laws, From Middle Class to Desperate" (2004) 26 Nat'l L J 27, 28.

${ }_{923}$ See Part V Judgment of the Tribunal.

924 Taylor Final Report, above n 169, 78.
} 
As a German citizen and lawyer, I am ashamed of the cowardice of my colleagues during the Third Reich. Few expected them to resist actively or refuse any orders but, at least, they should have followed the lowest moral and ethical standards of humankind and resign from office.

Many of the jurists, who had collaborated with the Nazis, later criticised the Nuremberg Trials as an occurrence of victor's justice. Some of them also became leading members of West Germany's new judiciary in the 1950s, which denied trying Nazi jurists to a large extent. I do not blame their criticism of Nuremberg as this paper shows that many aspects were controversial, but I do condemn their refusal to deal with their own past.

However, it enhances the legacy of the Justice Trial because, without the trial, the dimension of involvement of Germany's judiciary in Nazi crimes would probably be unknown today. The trial record, therefore, stands not only for the individual guilt of certain members of Nazi Germany's judicial system, but also as a memorial for future generations of jurists. 


\section{APPENDIX: PICTURES FROM THE TRIAL}

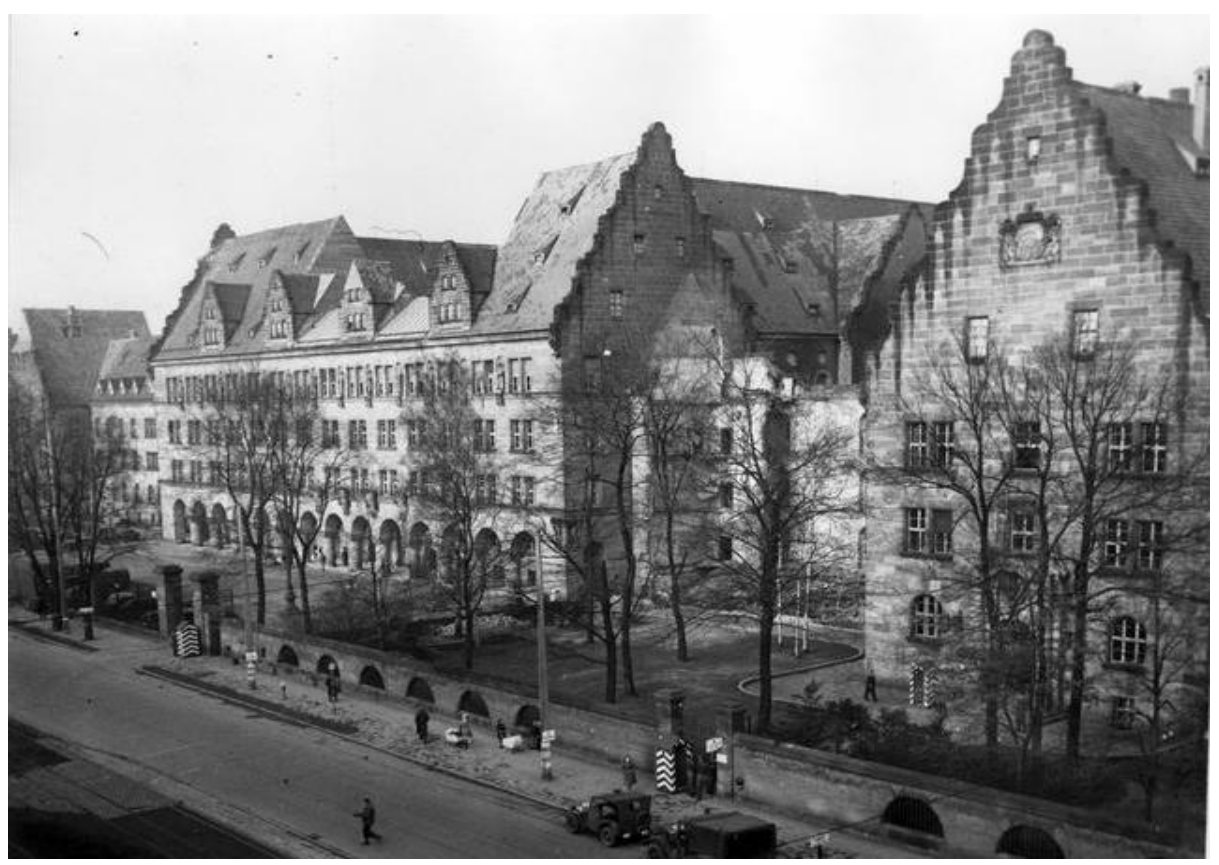

The Nuremberg Palace of Justice in $1947^{925}$

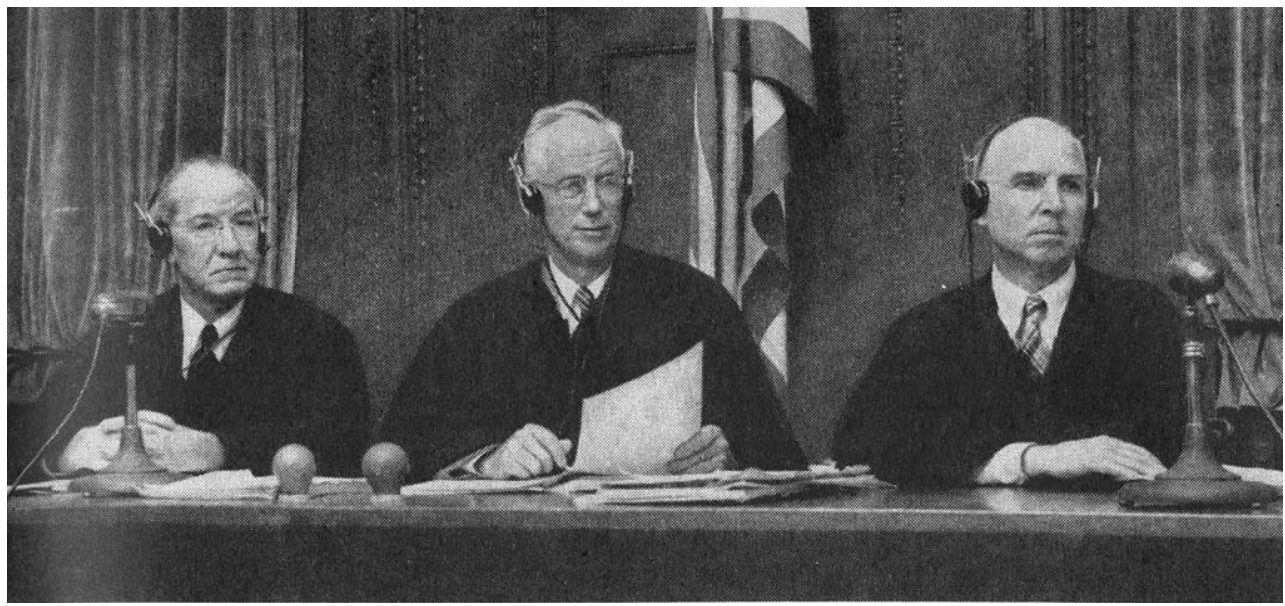

The judges of US Military Tribunal III after the previous presiding Judge Carrington T Marshall had resigned for reasons of illness (from left to right: Judge Mallory B Blair, Presiding Judge James T Brand and Judge Justin W Harding) ${ }^{926}$

\footnotetext{
${ }^{925}$ Picture from www.holocaustresearchproject.org (last accessed 25 March 2010).

926 Picture from Charles M LaFollette "Justice Case at Nuremberg Part II" (1948) 139 Information Bulletin, Magazine for US Military Government in Germany 11, 11.
} 


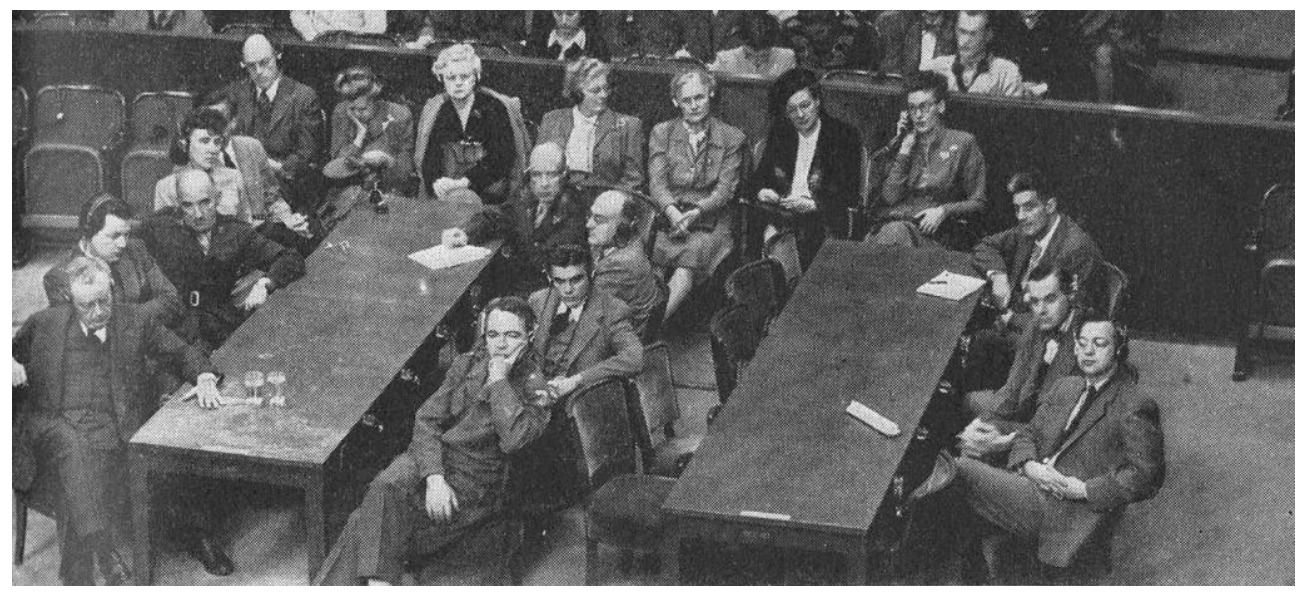

The Prosecution Counsel (Deputy Chief Charles M LaFollette and Chief Prosecutor Telford Taylor are sitting on the left table in front $)^{927}$

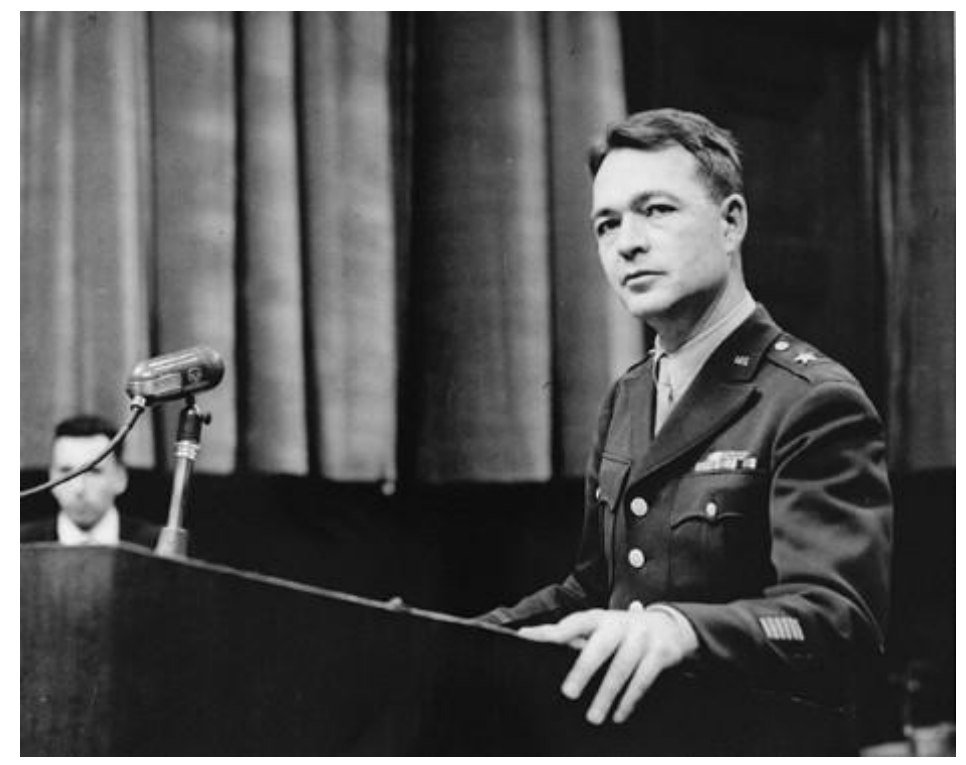

Chief Prosecutor, Brigadier General Telford Taylor ${ }^{928}$

${ }^{927}$ Picture from Ibid, 13.

${ }^{928}$ Picture from www.law.umkc.edu (last accessed 25 March 2010). 


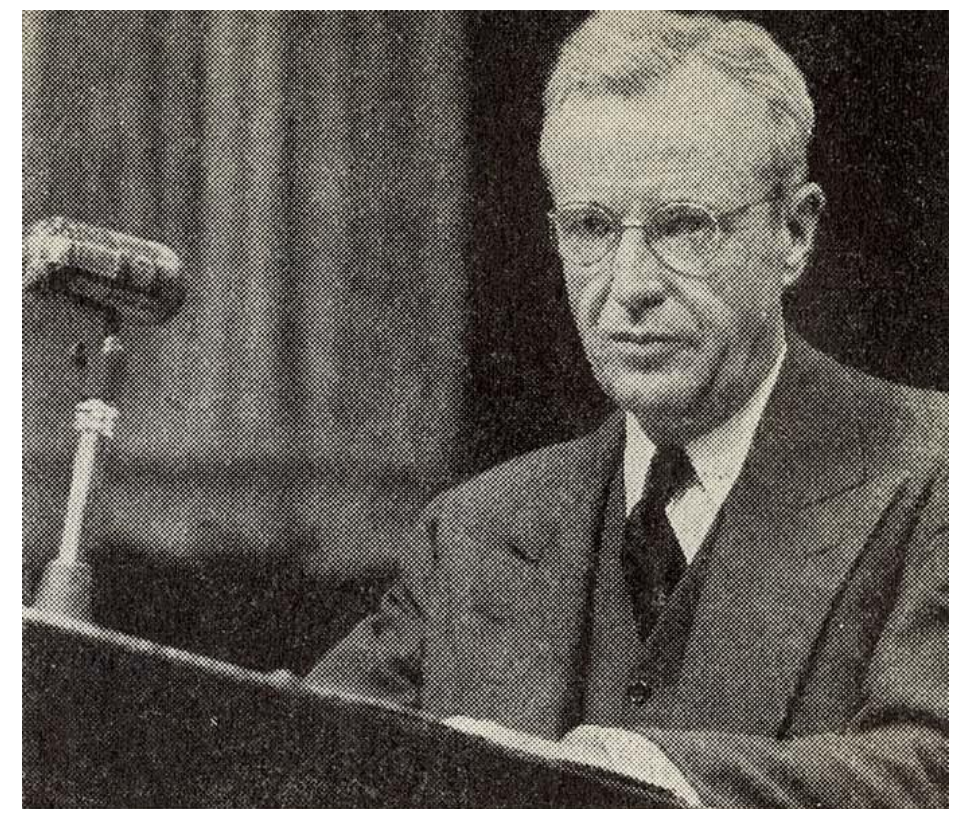

Deputy Chief for the Prosecution, Charles M LaFollette ${ }^{929}$

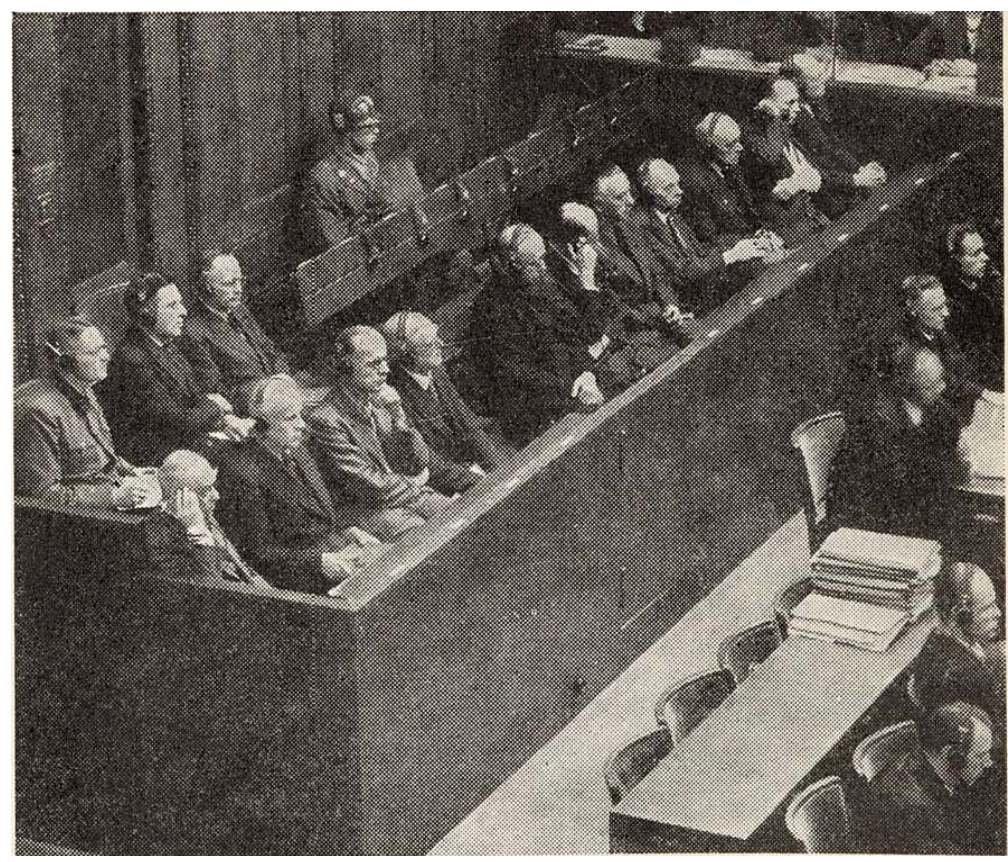

The defendants' dock $^{930}$

\footnotetext{
${ }^{929}$ Picture from LaFollette, above n 280, 9.

930 Picture from Charles M LaFollette "Justice Case at Nuremberg Part V" (1948) 142
} Information Bulletin, Magazine of US Military Government in Germany 9, 9. 


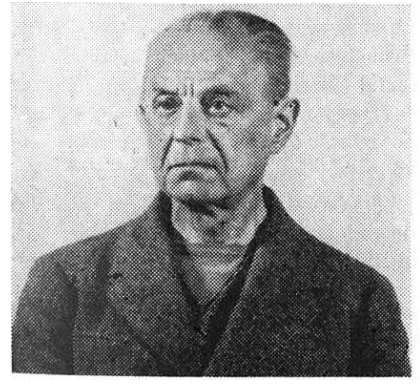

Franz Schlegelberger

State Secretary and Acting Minister of Justice. Guilty of war crimes and crimes against humanity. Sentenced to imprisonment for life. ${ }^{931}$

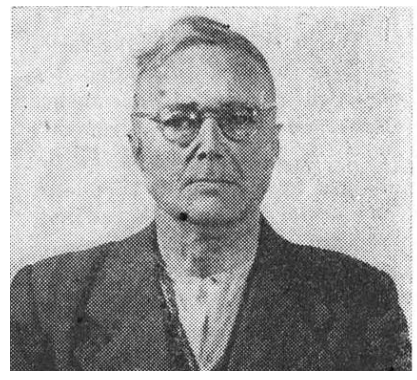

\section{Ernst Lautz}

Chief Public Prosecutor of the People's Court. Guilty of war crimes and crimes against humanity. Sentenced to ten years' imprisonment. ${ }^{934}$

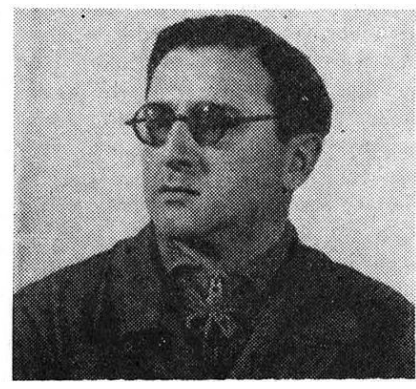

Rudolf Oeschey

Chief Justice of the Special Court Nuremberg. Guilty of crimes against humanity and membership in the SS. Sentenced to imprisonment for life. ${ }^{932}$

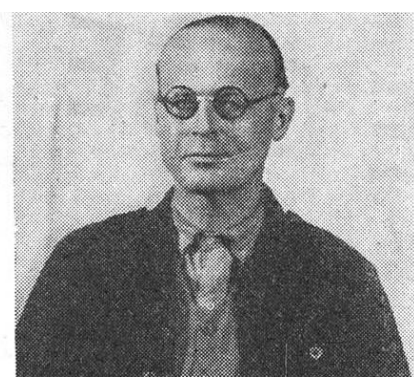

\section{Curt Rothenberger}

State Secretary of the Ministry of Justice. Guilty of war crimes and crimes against humanity. Sentenced to seven years' imprisonment. ${ }^{935}$

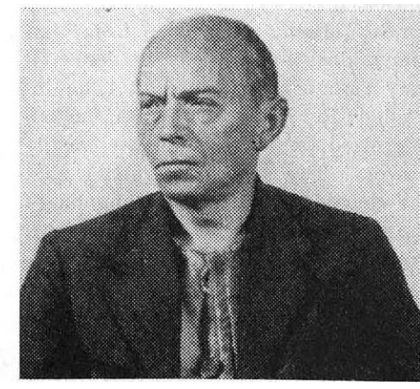

\section{Oswald Rothaug}

Senior Public Prosecutor of the People's Court and Chief Justice of the Special Court Nuremberg. Guilty of crimes against humanity. Sentenced to imprisonment for life. ${ }^{933}$

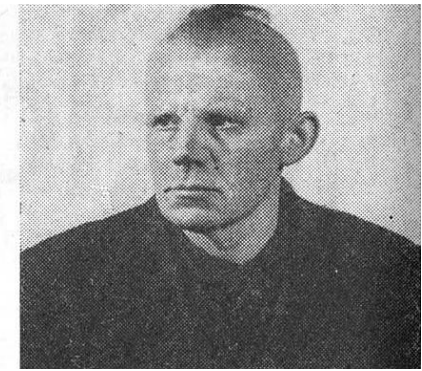

\section{Herbert Klemm}

State Secretary of the Ministry of Justice. Guilty of war crimes and crimes against humanity. Sentenced to imprisonment for life. ${ }^{936}$

\footnotetext{
${ }^{931}$ Picture from Charles M LaFollette "Justice Case at Nuremberg Part IV" (1948) 141 Information Bulletin, Magazine of US Military Government in Germany 17, 17.

${ }_{932}$ Picture from Ibid.

${ }^{933}$ Picture from Ibid.

${ }^{934}$ Picture from Ibid, 18.

${ }^{935}$ Picture from Ibid.

${ }^{936}$ Picture from Ibid.
} 


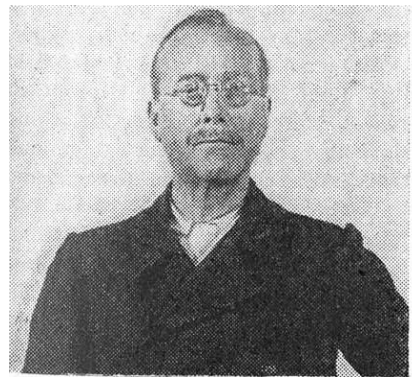

\section{Wolfgang Mettgenberg}

Representative of the Chief of the Criminal Legislation and Administration Division of the Ministry of Justice. Guilty of war crimes and crimes against humanity. Sentenced to ten years' imprisonment. ${ }^{937}$

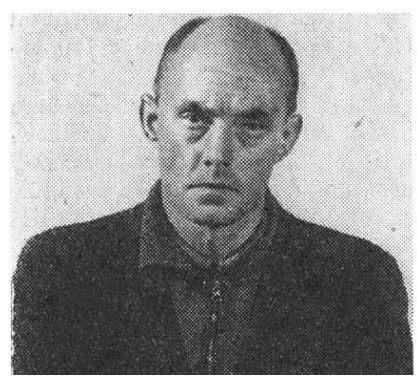

\section{Guenther Nebelung}

Chief Justice of the Fourth Senate of the People's Court. Acquitted. ${ }^{940}$

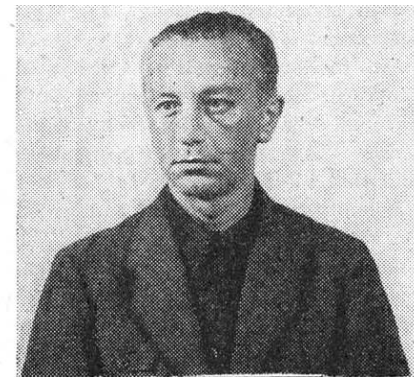

\section{Guenther Joel}

Legal advisor to the Minister of Justice concerning criminal prosecution. Guilty of war crimes, crimes against humanity and membership in the SS. Sentenced to ten years' imprisonment. ${ }^{938}$

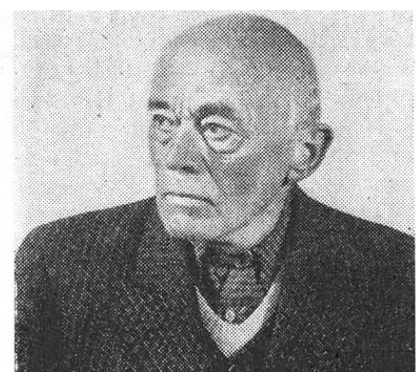

\section{Paul Barnickel}

Senior Public Prosecutor of the People's Court. Acquitted. ${ }^{941}$

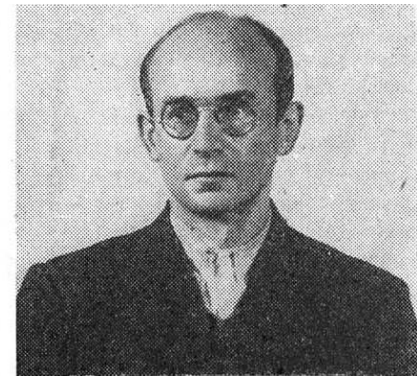

\section{Wilhelm von Ammon}

Ministerial Counsellor of the Criminal Legislation and Administration Division of the Ministry of Justice. Guilty of war crimes and crimes against humanity. Sentenced to ten years' imprison-

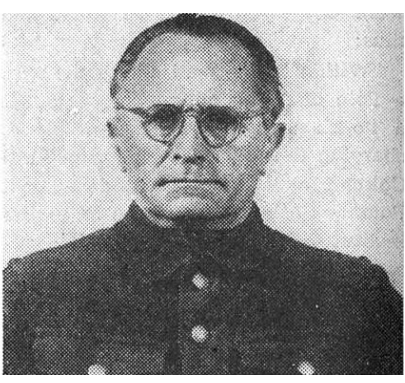

\section{Josef Altstoetter}

Chief of Civil Law and Procedure Division of the Ministry of Justice. Guilty of membership in the SS. Sentenced to five years' imprisonment. ${ }^{942}$

\footnotetext{
${ }^{937}$ Picture from Ibid, 19.

${ }^{938}$ Picture from Ibid.

939 Picture from Ibid.

${ }^{940}$ Picture from Ibid, 20.

${ }^{941}$ Picture from Ibid.

${ }^{942}$ Picture from Ibid.
} 


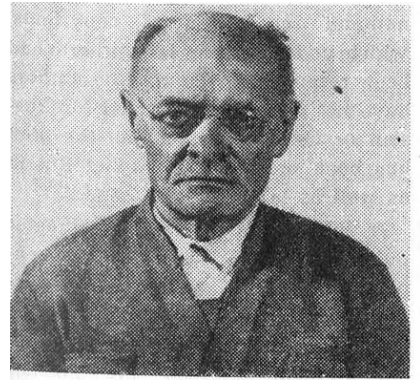

Karl Engert

Chief of the Penal Administration Division and Secret Prison Inmate Transfer Division of the Ministry of Justice. Not tried because of illness. ${ }^{943}$

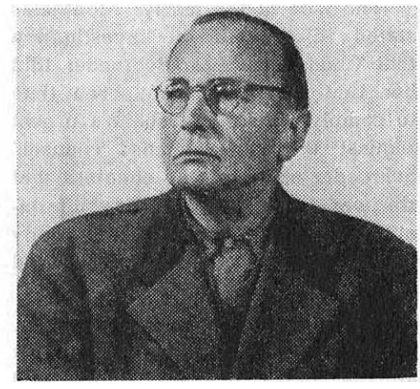

\section{Hans Petersen}

Lay Judge of the First Senate of the People's Court and Lay Judge of the Special Senate of the People's Court. Acquitted. $^{944}$

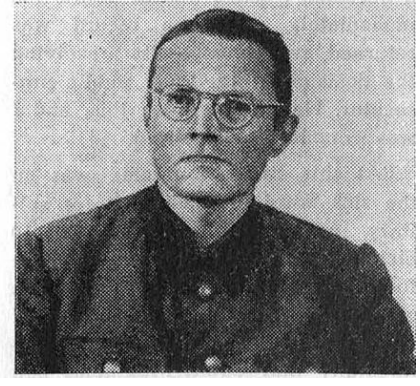

\section{Hermann Cuhorst}

Chief Justice of the Special Court in Stuttgart and Chief Justice of the First Criminal Senate of District Court in Stuttgart. Acquitted. $^{945}$

943 Picture from Ibid, 21.

944 Picture from Ibid.

${ }^{945}$ Picture from Ibid. 


\section{BIBLIOGRAPHY}

\section{PRIMARY SOURCES}

\section{A Legislation, Treaties, Declarations}

Basic Law for the Federal Republic of Germany 1949 (as amended up to June 2008)

Berlin Declaration Regarding the Defeat of Germany and the Assumption of Supreme Authority by Allied Powers (5 June 1945)

available at www.avalon.law.yale.edu (last accessed 25 March 2010)

Beschluss des Grossdeutschen Reichstags vom 26. April 1942 (Resolution of the Great-German Reichstag from 26 April 1942) available at www.verfassungen.de (last accessed 25 March 2010)

Charter of the International Military Tribunal (8 August 1945) available in The United States of America $v$ Josef Altstoetter and others (Justice Case) (1947) III Trials of War Criminals before the Nuernberg Military Tribunal under Control Council Law No. 10 (Case No 3) XIIIXVII

Control Council Law No. 101945 (US, UK, France, USSR) available in The United States of America $v$ Josef Altstoetter and others (Justice Case) (1947) III Trials of War Criminals before the Nuernberg Military Tribunal under Control Council Law No. 10 (Case No 3) XVIIIXXII

Convention on the Prevention and Punishment of the Crime of Genocide (9 December 1948) available at www.un.org/en/ (last accessed 25 March 2010) 
Erstes Gesetz zur Ueberleitung der Rechtspflege auf das Reich vom 16. Februar 1934 (First Law for Centralisation of Clemency Powers to the President of the Reich from 16 February 1934) 17 RGBl 1934 I 91 available at www.servat.unibe.ce/law/dns/ (last accessed 25 March 2010)

German Civil Code 1896 (as amended on 4 December 2008)

German Criminal Code 1871 (as amended on 4 July 2009)

Gesetz zur Behebung der Not von Volk und Reich vom 24. Maerz 1933 (Law concerning the Relief of Distress of the Nation and the Reich from 24 March 1933) 25 RGBl 1933 I 141 available at www.servat.unibe.ce/law/dns/ (last accessed 25 March 2010)

Gesetz zur Abwehr politischer Gewalttaten vom 4. April 1933 (Law for the Protection against Violent Political Acts from 4 April 1933) 31 RGB1 I 162 available at www.servat.unibe.ce/law/dns/ (last accessed 25 March 2010)

Gesetz ueber die Zulassung zur Rechtsanwaltschaft vom 7. April 1933 (Law concerning the Admission to the Legal Profession from 7 April 1933) 36 RGBl 1933 I 188

available at www.servat.unibe.ce/law/dns/ (last accessed 25 March 2010)

Gesetz gegen die Neubildung von Parteien vom 14. Juli 1933 (Law against the creation of Political Parties from 14 July 1933) 81 RGBl 1933 I 479 available at www.servat.unibe.ce/law/dns/ (last accessed 25 March 2010)

Gesetz ueber den Neuaufbau des Reichs vom 30. Januar 1934 (Law for the Restructuring of the Reich from 30 January 1934) 11 RGB1 1934 I 75 available at www.servat.unibe.ce/law/dns/ (last accessed 25 March 2010) 
Gesetz zur Aenderung von Vorschriften des Strafrechts und des Strafverfahrens vom 24. April 1934 (Law for the amendment of the Provisions of Criminal Law and Procedure from 24 April 1934) 47 RGB1 1934 I 341

available at www.servat.unibe.ce/law/dns/ (last accessed 25 March 2010)

Gesetz zur Aenderung des Strafgesetzbuchs vom 28. Juni 1935 (Law Concerning the Alteration of the Penal Code from 28 June 1935) 70 RGB1 1935 I 839

available at www.servat.unibe.ce/law/dns/ (last accessed 25 March 2010)

Gesetz zum Schutze des deutschen Blutes und der deutschen Ehre vom 15. September 1935 (Law for the Protection of German Blood and German Honour from 15 September 1935) 100 RGBl 1935 I 1146

available at www.servat.unibe.ce/law/dns/ (last accessed 25 March 2010)

Hague Convention with Respect to the Laws and Customs of War on Land (Hague II) (29 July 1899)

available at www.avalon.law.yale.edu (last accessed 25 March 2010)

Hague Convention Respecting the Laws and Customs of War on Land (Hague IV) (18 October 1907)

available at www.avalon.law.yale.edu (last accessed 25 March 2010)

Kellog-Briand Pact (27 August 1928)

available at www.avalon.law.yale.edu (last accessed 25 March 2010)

London Agreement (8 August 1945)

available in The United States of America $v$ Josef Altstoetter and others (Justice Case) (1947) III Trials of War Criminals before the Nuernberg Military Tribunal under Control Council Law No. 10 (Case No 3) XI-XVIII 
Military Ordinance No. 71946 (US)

available in The United States of America $v$ Josef Altstoetter and others (Justice Case) (1947) III Trials of War Criminals before the Nuernberg Military Tribunal under Control Council Law No. 10 (Case No 3) XXIIIXXIX

Moscow Declaration on German Atrocities (released 1 November 1943)

available in The United States of America $v$ Josef Altstoetter and others (Justice Case) (1947) III Trials of War Criminals before the Nuernberg Military Tribunal under Control Council Law No. 10 (Case No 3) X

Protocol of Proceedings of the Yalta (Crimea) Conference (11 February 1945)

available at www.avalon.law.yale.edu (last accessed 25 March 2010)

Reichsbuergergesetz vom 15. September 1935 (Reich Citizenship Law from 15 September 1935) 100 RGB1 1935 I 1146

available at www.servat.unibe.ce/law/dns/ (last accessed 25 March 2010)

Rome Statute of the International Criminal Court (17 July 1998)

available at www.un.org/en/ (last accessed 25 March 2010)

Teheran Declaration of the Three Powers (1 December 1943)

available at www.avalon.law.yale.edu (last accessed 25 March 2010)

Treaty of Versailles (28 June 1919)

available at www.avalon.law.yale.edu (last accessed 25 March 2010)

Universal Declaration of Human Rights (10 December 1948)

available at www.un.org/en/ (last accessed 25 March 2010) 
Verordnung des Reichspraesidenten zum Schutz von Volk und Staat vom 28. Februar 1933 (Order of the Reich President for the Protection of People and State from 28 February 1933) 17 RGBl 1933 I 83

available at www.servat.unibe.ce/law/dns/ (last accessed 25 March 2010)

Weimar Constitution 1919 (Germany)

available in Horst Hildebrandt (ed) Die deutschen Verfassungen des 19. und 20. Jahrhunderts (10 ed, Ferdinand Schoeningh Verlag, Paderborn, 1977)

\section{B Cases}

The United States of America, the French Republic, the United Kingdom of Great Britain and Northern Ireland, and the Union of Soviet Socialist Republics v Hermann Wilhelm Goering and others (International Military Tribunal) (1945-1946) I and II Trial of the Major War Criminals before the International Military Tribunal

The United States of America v Karl Brandt and others (Medical Case) (1946-1947) I and II Trials of War Criminals before the Nuernberg Military Tribunal under Control Council Law No. 10 (Case No 1) 1

The United States of America v Josef Altstoetter and others (Justice Case) (1947) III Trials of War Criminals before the Nuernberg Military Tribunal under Control Council Law No. 10 (Case No 3) 1

The United States of America v Oswald Pohl and others (Pohl Case) (19471948) V Trials of War Criminals before the Nuernberg Military Tribunal under Control Council Law No. 10 (Case No 4) 193

The United States of America v Friedrich Flick and others (Flick Case) (1947) VI Trials of War Criminals before the Nuernberg Military Tribunal under Control Council Law No. 10 (Case No 5) 1 
The United States of America v Otto Ohlendorf and others (Einsatzgruppen Case) (1947-1948) IV Trials of War Criminals before the Nuernberg Military Tribunal under Control Council Law No. 10 (Case No 9) 1

The United States of America v Alfried Krupp and others (Krupp Case) (1947-1948) IX Trials of War Criminals before the Nuernberg Military Tribunal under Control Council Law No. 10 (Case No 10) III

Urteil des Bundesgerichtshofs vom 16. November 1995 (Judgment of the German Federal Supreme Court (BGH) from 16 November 1995) 41 BGHSt 317 (BGH -5 StR 747/94-)

Urteil des Bundesgerichtshofs vom 30. April 1968 (Judgment of the German Federal Supreme Court (BGH) from 30 April 1968) 21 NJW 1339 (BGH -5 StR 670/67-)

\section{Other Official Documents}

General Report of the United States Commission to the Peace Conference of The Hague (31 July 1899)

available at www.avalon.law.yale.edu (last accessed 25 March 2010)

Jackson, Robert H Report of Robert H. Jackson: United States Representative to the International Conference on Military Trials, London, 1945. (US Government Printing Office, Washington DC, 1949)

Office of United States Chief of Counsel for Prosecution of Axis Criminality Nazi Conspiracy and Aggression: Opinion and Judgment (US Government Printing Office, Washington DC, 1947) 
Procedure, Practice and Administration XV Trials of War Criminals before the Nuernberg Military Tribunal under Control Council Law No. 10 (US Government Printing Office, Washington DC, 1946-1949)

Taylor, Telford Final Report to the Secretary of the Army on the Nuernberg War Crimes Trials under Control Council Law No. 10 (US Government Printing Office, Washington DC, 1949)

United Nations International Law Commission Principles of International Law Recognized in the Charter of the Nuernberg Tribunal and in the Judgment of the Tribunal (1950)

available at http://untreaty.un.org/ilc/texts/instruments/english/draft\% 20articles/7_1_1950.pdf (last accessed 25 March 2010)

United Nations War Crimes Commission Law Reports of Trials of War Criminals: Trial of Josef Altstoetter and others (Case no 35) (Vol VI, His Majesty's Stationery Office, London, 1948)

\section{SECONDARY SOURCES}

\section{A Texts}

Bass, Gary J Stay the Hand of Vengeance: The Politics of War Crimes Tribunals (Princeton University Press, Princeton, 2002)

Bassiouni, M Cherif (ed) Post-Conflict Justice (Transnational Publishers, Ardsley, 2002)

Bassiouni, M Cherif Introduction to International Criminal Law (Transnational Publishers, Ardsley, 2003) 
Bassiouni, M Cherif (ed) International Criminal Law (Vol 1, 2 ed, Transnational Publishers, Ardsley, 1998)

Bassiouni, M Cherif Crimes against Humanity in International Criminal Law (2 ed, Kluwer Law International, The Hague, 1999)

Beigbeder, Yves Judging War Criminals: The Politics of International Justice (St. Martin's Press, New York, 1999)

Benton, Wilbourn E and Georg Grimm (eds) Nuremberg: German Views of the War Trials (Southern Methodist University Press, Dallas, 1955)

Blumenthal, David A and Timothy L H McCormack (eds) The Legacy of Nuremberg: Civilising Influence or Institutionalised Vengeance? (Martinus Nijhoff Publishers, Leiden, 2008)

Buscher, Frank M The U.S. War Crimes Trials Program in Germany, 19461955 (Greenwood Press, New York, 1989)

Cassese, Antonio (ed) The Oxford Companion to International Criminal Justice (Oxford University Press, Oxford, 2009)

Cassese, Antonio International Criminal Law (2 ed, Oxford University Press, Oxford, 2008)

Conot, Robert E Justice at Nuremberg (Harper \& Row, New York, 1983)

Cooper, Robert The Nuremberg Trial (Penguin Books, Harmondsworth, 1947)

Davidson, Eugene The Trial of the Germans: An Account of the Twenty-two Defendants before the International Military Tribunal at Nuremberg (University of Missouri Press, Columbia, 1997) 
Fournet, Caroline International Crimes: Theories, Practice and Evolution (Cameron May, London, 2006)

Futamura, Madoka War Crimes Tribunals and Transitional Justice: The Tokyo Trial and the Nuremberg Legacy (Routledge, New York, 2008)

Ginsburgs, George and Vladimir N Kudriavtsev (eds) The Nuremberg Trial and International Law (Martinus Nijhoff Publishers, Dordrecht, 1990)

Hagan, John Justice in the Balkans: Prosecuting War Crimes in the Hague Tribunal (University of Chicago Press, Chicago, 2003)

Hankel, Gerd and Gerhard Stuby (eds) Strafgerichte gegen Menschheitsverbrechen: Zum Voelkerstrafrecht 50 Jahre nach den Nuernberger Prozessen (Hamburger Edition HIS, Hamburg, 1995)

Harris, Bede Essential Constitutional Law (2 ed, Routledge-Cavendish, London, 2004)

Harris, Whitney R Tyranny on Trial: The Evidence at Nuremberg (Southern Methodist University Press, Dallas, 1954)

Heberer, Patricia and Juergen Matthaeus (eds) Atrocities on Trial: Historical Perpectives on the Politics of Prosecuting War Crimes (University of Nebraska Press, Lincoln, 2008)

Heydecker, Joe J and Johannes Leeb (eds) The Nuremberg Trial: A History of Nazi Germany as Revealed Through the Testimony at Nuremberg (Greenwood Press, Westport, 1975)

Hildebrandt, Horst (ed) Die deutschen Verfassungen des 19. und 20. Jahrhunderts (10 ed, Ferdinand Schoeningh Verlag, Paderborn, 1977) 
Irving, David Nuremberg: The Last Battle (Focal Point Publications, London, 1996)

Junker, Detlef (ed) The United States and Germany in the Era of the Cold War, 1945-1968 (Vol I, 2 ed, Publications of the German Historical Institute, Washington DC, 2004)

Kempner, Robert M W Anklaeger einer Epoche: Lebenserinnerungen (Ullstein Verlag, Frankfurt/Main, 1986)

Koch, Hannsjoachim Wolfgang In the Name of the Volk: Political Justice in Hitler's Germany (Tauris, London, 1989)

Kochavi, Arieh J Prelude to Nuremberg: Allied War Crimes Policy and the Question of Punishment (University of North Carolina Press, Chapel Hill, 1998)

Kramer, Helmut Plaedoyer fuer ein Forum zur juristischen Zeitgeschichte (WMIT Druck und Verlags GmbH, Bremen, 1998)

Laughland, John A History of Political Trials: From Charles I to Saddam Hussein (Peter Lang, Oxford, 2008)

Mann, Golo Deutsche Geschichte des 19. und 20. Jahrhunderts (Fischer Verlag, Frankfurt/Main, 1966)

Maogoto, Jackson Nyamuya War Crimes and Realpolitik: International Justice from World War I to the $21^{\text {st }}$ Century (Lynne Rienner Publishers, Boulder, 2004)

Marrus, Michael R The Nuremberg War Crimes Trial 1945-1946: A Documentary History (Bedford Books, Boston, 1997) 
Martin, Roy A Inside Nuernberg: Military Justice for Nazi War Criminals

(White Mane Books, Shippensburg, 2000)

Maser, Werner Nuremberg: A Nation on Trial (Allen Lane, London, 1979)

Maugham, Viscount Frederic H U.N.O. and War Crimes (John Murray, London, 1951)

McConnell, Tandy (ed) History in Dispute, Vol. 11: The Holocaust, 19331945 (Gale, Farmington Hills, 2003)

Meron, Theodor War Crimes Law Comes of Age (Oxford University Press, Oxford, 1999)

Mettraux, Guenael (ed) Perspectives on the Nuremberg Trial (Oxford University Press, Oxford, 2008)

Morgan, John $\mathrm{H}$ The Great Assize: An Examination of the Law of the Nuremberg Trials (John Murray, London, 1948)

Morris, Douglas G Justice Imperiled: The Anti-Nazi Lawyer Max Hirschberg in Weimar Germany (University of Michigan Press, Ann Arbor, 2005)

Morris, Grant Law Alive: The New Zealand Legal System in Context (Oxford University Press, Oxford, 2008)

Mueller-Ballin, Gabi Die Nuernberger Prozesse 1945-1949 (BZ-Materialien Band 1, Nuernberg, 1995)

Mueller, Gerhard OW and Edward M Wise (eds) International Criminal Law (Rothman, South Hackensack, 1965) 
Mueller, Ingo Hitler's Justice: The Courts of the Third Reich (Harvard University Press, Cambridge, 1991)

Overy, Richard J Interrogations: The Nazi Elite in Allied Hands, 1945 (Allen Lane, London, 2001)

Peschel-Gutzeit, Lore Maria (ed) Das Nuernberger Juristen-Urteil von 1947 (Nomos Verlag, Baden-Baden, 1996)

Salter, Michael Nazi War Crimes, US Intelligence and Selective Prosecution at Nuremberg: Controversies Regarding the Role of the Office of Strategic Services (Routledge-Cavendish, New York, 2007)

Sands, Philippe (ed) From Nuremberg to The Hague: The Future of International Criminal Justice (Cambridge University Press, New York, 2003)

Schlegelberger, Franz (ed) Handelsgesetzbuch in der seit 1. Oktober 1937 geltenden Fassung (ohne Seerecht) (Vol 1, 4 ed, Verlag Franz Vahlen, Berlin, 1965-66)

Smith, Bradley F Reaching Judgment at Nuremberg (Basic Books, New York, 1977)

Smith, Bradley F The Road to Nuremberg (Basic Books, New York, 1981)

Starke, Joseph G An Introduction to International Law (10 ed, Butterworths, London, 1989)

Stoltzfus, Nathan and Henry Friedlander (eds) Nazi Crimes and the Law (Cambridge University Press, New York, 2008) 
Taylor, Telford The Anatomy of the Nuremberg Trials (Knopf, New York, 1992)

Thakur, Ramesh and Peter Malcontent (eds) From Sovereign Impunity to International Accountability: The Search for Justice in a World of States (United Nations University Press, New York, 2004)

Trainin, Aron N Hitlerite Responsibility Under Criminal Law (Hutchinson, London, 1945)

Tusa, Ann and John Tusa The Nuremberg Trial (Macmillan, London, 1983)

Washington, Ellis The Nuremberg Trials: Last Tragedy of the Holocaust (University Press of America, Lanham, 2008)

Wiesenthal, Simon Justice not Vengeance (Weidenfeld and Nicolson, London, 1989)

Woetzel, Robert $\mathrm{K}$ The Nuremberg Trials in International Law with a Postlude on the Eichmann Case (rev ed, Stevens, London, 1962)

\section{B Journals and Articles}

Biddiss, Michael "Victor's Justice? The Nuremberg Tribunal" (1995) 45 History Today 40

Brunner, Joseph "American Involvement in the Nuremberg War Crimes Trial Process" (Winter 2002) Michigan Journal of History I

Drecktrah, Volker Friedrich "Der Versuch, aus der Vergangenheit zu lernen, ist nicht ganz gescheitert" (2003) 11 Neue Justiz 578 
Dreier, Horst “Gustav Radbruch und die Mauerschützen“ (1997) 52 Juristen Zeitung 421

Freeman, Alwyn V "War Crimes by Enemy Nationals Administering Justice in Occupied Territory" (1947) 41 American Journal of International Law 579

Fried, John H E "Transfer of Civilian Manpower from Occupied Territory" (1946) 40 American Journal of International Law 303

Frommer, Hartmut and Kathrin Westner "Die Vernichtung von Leo Katzenberger durch das Sondergericht Nuernberg" (1998) 85 Mitteilungen des Vereins fuer Geschichte der Stadt Nuernberg 315

Fuller, Lon L "Positivism and Fidelity to Law: A Reply to Professor Hart" (1958) 71 Harvard Law Review 630

Gonshak, Henry "Does Judgment at Nuremberg accurately depict the Nazi War Crimes Trial?” (2008) 31 Journal of American Culture 153

Haberer, Erich "History and Justice: Paradigms of the Prosecution of Nazi Crimes" (2005) 19 Holocaust and Genocide Studies 487

Hart, H L A "Positivism and the Separation of Law and Morals" (1958) 71 Harvard Law Review 593

Kastner, Klaus "Der Dolch des Moerders war unter der Robe des Juristen verborgen: Der Nuernberger Juristen-Prozess 1947” (1997) Juristische Arbeitsblaetter 699

Kastner, Klaus "Der Nuernberger Prozess" (1995) Juristische Arbeitsblaetter 802 
Kelsen, Hans "The International Legal Status of Germany to be Established Immediately upon Termination of the War" (1944) 38 American Journal of International Law 689

Kramer, Helmut "Richter vor Gericht: Die juristische Aufarbeitung der Sondergerichtsbarkeit“ (2007) 15 Juristische Zeitgeschichte NRW 121

LaFollette, Charles M. "Justice Case at Nuremberg Part I" (1948) 138 Information Bulletin, Magazine of US Military Government in Germany 9

LaFollette, Charles M. “Justice Case at Nuremberg Part II” (1948) 139 Information Bulletin, Magazine of US Military Government in Germany 11

LaFollette, Charles M. "Justice Case at Nuremberg Part III" (1948) 140 Information Bulletin, Magazine of US Military Government in Germany 15

LaFollette, Charles M. "Justice Case at Nuremberg Part IV" (1948) 141 Information Bulletin, Magazine of US Military Government in Germany 17

LaFollette, Charles M. "Justice Case at Nuremberg Part V" (1948) 142 Information Bulletin, Magazine of US Military Government in Germany 9

Marrus, Michael R. “The Nuremberg Trial: Fifty Years After” (1997) 66 American Scholar 563

Nathans, Eli "Legal Order as Motive and Mask: Franz Schlegelberger and the Nazi Administration of Justice" (2000) 18 Law and History Review 281

Ostendorf, Heribert "Politische Strafjustiz vor und nach 1945" (1999) 248 Informationen zur politischen Bildung 1

Radbruch, Gustav "Gesetzliches Unrecht und uebergesetzliches Recht" (1946) 1 Sueddeutsche Juristen-Zeitung 105 
Radbruch, Gustav "Statutory Lawlessness and Supra-Statutory Law (1946)" translated by Bonnie Litschewski-Paulson and Stanley L Paulson (2006) 26 Oxford Journal of Legal Studies 1

Reicher, Harry "A Turning Point in the Law, A Growing Momentum" (2004) 26 National Law Journal 38

Reicher, Harry "An Infamous Date: Nazi Laws, From Middle Class to Desperate" (2004) 26 National Law Journal 27

Rosenberg, Sheri P "The Nuremberg Trials: A Reappraisal and their Legacy” (2006) 27 Cardozo Law Review 1549

Segesser, Daniel Marc and Myriam Gessler "Raphael Lemkin and the International Debate on the Punishment of War Crimes (1919-1948)" (2005) 7 Journal of Genocide Research 453

Stimson, Henry L "The Nuremberg Trial: Landmark in Law" (1947) 25 Foreign Affairs 179

Stoltzfus, Nathan "Nazi Crimes and the Law" (2004) 34 Bulletin of the German Historical Institute 153

Taylor, Telford “The Nuremberg Trials” (1955) 55 Columbia Law Review 488

Taylor, Telford "The Nuremberg War Crimes Trials: An Appraisal” (1949) 23 Proceedings of the Academy of Political Science 19

Wright, Quincy "War Crimes under International Law” (1946) 62 Law Quarterly Review 40 
Wyzanski, Charles E "Nuremberg: A Fair Trial? A Dangerous Precedent" (1946) 177, 4 The Atlantic Monthly 66

Wyzanski, Charles E "Nuremberg in Retrospect” (1946) 178, 6 The Atlantic Monthly 56

\section{Research Papers}

Bicknell, Kate "Is every International Criminal Law Trial Really a Show Trial?” (LLM Research Paper, Victoria University of Wellington, 2007)

Kazmi, Salman "Is Victor's Justice in Nuremberg Trial Justified or Not?" (Publication Quaid-e-Azam Law College, Pakistan, 2006)

Letzel, Alexandra "International Precedent or Victor's Justice” (Writing, University of California Santa Barbara, United States, 2007)

Schott, Susanne "Curt Rothenberger: Eine politische Biographie" (PhD Thesis, University of Halle-Wittenberg, Germany, 2001)

\section{Newspapers and Internet-Articles}

"Berlin Blockade and Airlift" www.britannica.com (last accessed 19 March 2010)

Brettin, Michael "Die Prozesse gegen die Mauerschuetzen und ihre Hintermaenner" (5 May 2009) Berliner Kurier Berlin (Germany) www.berlinonline.de/berliner-kurier (last accessed 19 March 2010)

Bytwerk, Randall L "Das Schwarze Korps" www.calvin.edu (last accessed 18 March 2010) 
Bytwerk, Randall L "Der Stuermer" www.calvin.edu (last accessed 19 March 2010)

Cherny, Robert “Telford Taylor” http://c250.columbia.edu/c250_celebrates/ remarkable_columbians/telford_taylor.html (last accessed 17 March 2010)

“Cold War" www.britannica.com (last accessed 19 March 2010)

Darnstaedt, Thomas "Das Weltgericht" (16 October 2006) 42 Der Spiegel Hamburg (Germany) 66 www.spiegel.de (last accessed 17 March 2010)

Darnstaedt, Thomas "Die Neuordnung der Welt" (23 October 2006) 43 Der Spiegel Hamburg (Germany) 160 www.spiegel.de (last accessed 19 March 2010)

“Ernst Kaltenbrunner” www.britannica.com (last accessed 18 March 2010)

“Gestapo” www.britannica.com (last accessed 17 March 2010)

"Hague Convention" www.britannica.com (last accessed 16 March 2010)

“Heinrich Himmler” www.britannica.com (last accessed 18 March 2010)

Hinrichs, Doerte and Hans Rubinich "Von Hitler zu Adenauer" (29 November 2007) Die Zeit Hamburg (Germany) www.zeit.de (last accessed 19 March 2010)

"International Criminal Tribunals and Special Courts" www.globalpolicy.org/international-justice (last accessed 19 March 2010)

“Julius Streicher” www.britannica.com (last accessed 19 March 2010) 
"La Follette, Charles Marion, (1898-1974)" www.bioguide.congress.gov (last accessed 17 March 2010)

Linder, Douglas O "The Nuremberg Trials: The Justice Trial" www.law.umkc.edu (last accessed 16 March 2010)

Lisciotto, Carmelo "The $1^{\text {st }}$ Nuremberg Trial" www.holocaustresearchproject.org (last accessed 17 March 2010)

“Marshall Plan” www.britannica.com (last accessed 19 March 2010)

“Martin Bormann” www.britannica.com (last accessed 18 March 2010)

Michmann, Jozeph and Michael Berenbaum "Denazification" www.jewishvirtuallibrary.org (last accessed 17 March 2010)

“Nuremberg Trials" www.loc.gov/rr/frd (last accessed 18 March 2010)

"Nuremberg Trials $60^{\text {th }}$ Anniversary: Justice Case" www.adl.org (last accessed 18 March 2010)

"Nurnberg Military Tribunals: Indictments" www.loc.gov/rr/frd (last accessed 16 March 2010)

Parks, W Hays “Telford Taylor, 1908-1998” www.icrc.org (last accessed 17 March 2010)

“Robert P. Patterson (1945-1947): Secretary of War" www.millercenter.org (last accessed 17 March 2010)

"SA" www.britannica.com (last accessed 18 March 2010) 
Severo, Richard "Telford Taylor, who prosecuted Nazis at Nuremberg War Crimes Trials, is dead at 90" (24 May 1998) The New York Times New York (US) www.nytimes.com (last accessed 17 March 2010)

"Sovereignty" West's Encyclopedia of American Law 2008 http://legaldictionary.thefreedictionary.com (last accessed 16 March 2010)

“SS” www.britannica.com (last accessed 17 March 2010)

Staas, Christian "Was damals Recht war ..." (25 February 2009) Die Zeit Hamburg (Germany) www.zeit.de (last accessed 19 March 2010)

"Subsequent Nuremberg Proceedings" www.ushmm.org (last accessed 16 March 2010)

"Telford Taylor" The Scribner Encyclopedia of American Lives, Volume 5: 1997-1999 http://galenet.galegroup.com.helicon.vuw.ac.nz/servlet/BioRC (last accessed 17 March 2010)

"The International Criminal Court" www.globalpolicy.org/internationaljustice (last accessed 19 March 2010)

“Truman Doctrine” www.britannica.com (last accessed 19 March 2010)

"Truth and Reconciliation Commission" www.justice.gov.za (last accessed 19 March 2010)

“Wilhelm II" www.bbc.co.uk (last accessed 16 March 2010)

“Wilhelm Keitel” www.britannica.com (last accessed 18 March 2010) 


\section{E Film}

Kramer, Stanley Judgment at Nuremberg (Movie, Roxlom Films, Los Angeles, 1961) 